\author{
UNIVERSIDADE DE SÃO PAULO \\ DEPARTAMENTO DE FONOAUDIOLOGIA \\ FACULDADE DE ODONTOLOGIA DE BAURU
}

GISELI BUENO BERTI

Tradução do questionário The Measure of Processes of Care (MPOC-56): análise da inteligibilidade do instrumento em língua portuguesa brasileira 

GISELI BUENO BERTI

\title{
Tradução do questionário The Measure of Processes of Care (MPOC-56): análise da inteligibilidade do instrumento em língua portuguesa brasileira
}

\author{
Dissertação apresentada à Faculdade de \\ Odontologia de Bauru da Universidade de São Paulo \\ para obtenção do título de Mestre em Ciências no \\ Programa de Fonoaudiologia, na área de \\ concentração Processos e Distúrbios da \\ Comunicação.
}

Orientadora: Profa. Dra. Adriane Lima Mortari Moret

Versão corrigida

BAURU 


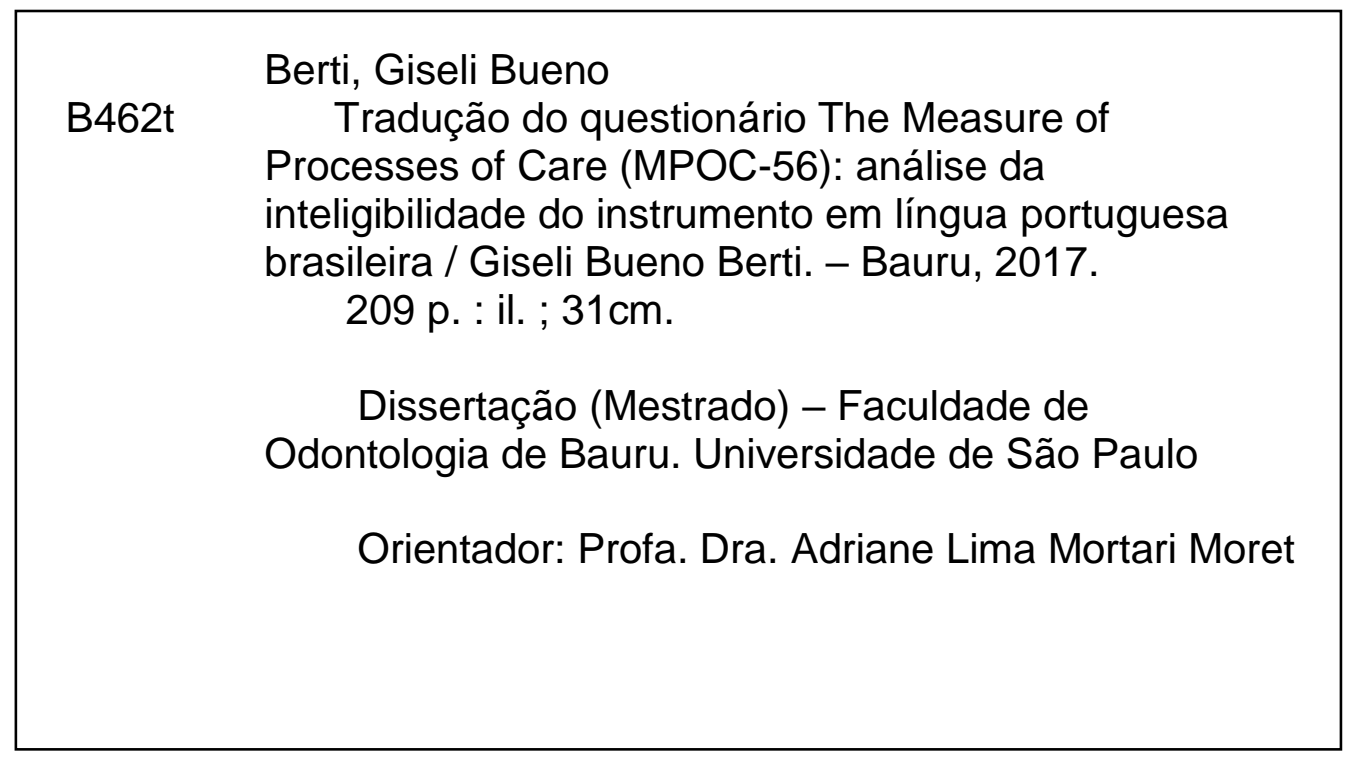

Nota: A versão original desta tese encontra-se disponível no Serviço de Biblioteca e Documentação da Faculdade de Odontologia de Bauru - FOB/USP.

Autorizo, exclusivamente para fins acadêmicos e científicos, a reprodução total ou parcial desta dissertação/tese, por processos fotocopiadores e outros meios eletrônicos.

Assinatura:

Data: 


\section{DEDICATÓRIA}

Dedico esta página aos meus pais Ademir Berti e Sebastiana Bueno Berti e ao meu irmão, Pedro Luis Bueno Berti que, em momento algum de minha vida, pessoal e acadêmica, deixaram de acreditar em meus sonhos, em meus estudos e, especialmente, em minha capacidade de ir além.

Dedico, também, ao meu filho Pietro, fonte de inspiração para que esse projeto se tornasse real e possível. 



\section{AGRADECIMENTOS}

Agradeço, em especial, a Deus, que possibilitou que um dos meus sonhos fosse concluído colocando pessoas especiais e iluminadas nesse percurso.

Agradeço ao meu noivo, Júlio César dos Santos, pelo apoio desde o processo de qualificação ao de finalização da dissertação.

À professora Dra. Adriane Lima Mortari Moret, que sempre me orientou com sabedoria e fez tornar possível a realização desta dissertação.

Aos professores da FOB/USP, pela imensa colaboração em minha vida acadêmica.

Aos meus alunos da faculdade, em especial aos do Curso de Letras, que acompanharam todo meu trajeto, desde o ingresso até o término do mestrado, agradeço pelo carinho e incentivo.

Aos meus professores da Universidade do Sagrado Coração, que me ensinaram a ser o profissional de tradução que sou e a sempre amar a profissão que escolhi.

E aos meus amigos que me apoiaram nessa jornada, incentivando meus projetos e minha continuidade na vida acadêmica. Agradeço, em especial, à minha amiga Aline Grazielli de Lucci, por todo carinho, atenção e preocupação dispensados a mim não só neste trajeto, mas em todos esses anos de amizade. 

"O trabalho de tradução é, por natureza, um trabalho de habilidade linguística, de competência cultural e de paciência. O tradutor deve ser como um vidro transparente que deixa passar toda a luz, sem deixar-se ver, quer dizer, sem alterar o sentido." 



\section{RESUMO}

\section{Tradução e adaptação do questionário The Measure of Processes of Care (MPOC-56): análise da inteligibilidade do instrumento em língua portuguesa brasileira}

A tradução de protocolos na área da saúde tem possibilitado a aplicação de testes elaborados internacionalmente em virtude da baixa elaboração de instrumentos no Brasil, sendo, dessa forma, a tradução, uma ferramenta para a validação desses instrumentos e sua utilização por pesquisadores brasileiros. Entretanto, a maioria das traduções não é realizada por profissionais de tradução, mas sim por qualquer indivíduo que tenha o conhecimento linguístico do idioma estrangeiro e da língua portuguesa não sendo, dessa forma, profissional da área. Esse aspecto desfavorece a inteligibilidade do texto, isto é, o instrumento é traduzido, sua interpretação por parte dos participantes, torna-se ambígua ou confusa, em virtude da falta de compreensão na própria língua portuguesa do documento. Ao propor a tradução em língua portuguesa do instrumento Measure of Processes of Care - 56 (MPOC-56), elaborado no Canadá e com a finalidade de verificar o atendimento do paciente por profissionais e pelo centro de terapia sob a perspectiva dos pais e a verificação da inteligibilidade permite ao tradutor não somente legitimar sua tradução, como também tornar mais acessível ao público em geral uma construção semântica, para que não ocorram equívocos na aplicação do questionário validado, tornando-o, dessa forma, um instrumento relevante para a área da Saúde e da Tradução Científica. Desse modo, o objetivo geral buscou traduzir o instrumento e verificar sua inteligibilidade na Língua Portuguesa. A pesquisa teve caráter metodológico, em virtude de investigações dos métodos de obtenção, organização e análise dos dados para a tradução de um instrumento. Para compor a metodologia, também foi utilizada a etapa do brainstorming, a qual contribuiu para o diálogo entre os peritos da área e a pesquisadora, objetivando a inteligibilidade do instrumento. Por meio do brainstorming, foi possível constatar que a etapa da retrotradução pode ser dispensada do processo tradutório em consequência do trabalho do profissional de tradução com os peritos bilíngues da área.

Palavras-chave: Tradução. Retrotradução. MPOC-56. Inteligibilidade. 



\section{ABSTRACT \\ Translation and adaptation to Brazilian Portuguese Language of the questionnaire "The Measure of Processes of Care": analysis of instrument readability}

Health protocols translation has made possible the application of tests internationally organized due to a low production of instruments in the Brazilian Health area. So, translation is made a tool to validate these instruments and its utilization by Brazilian researchers. Nevertheless, most translations are not elaborated by translator professionals, but by any individual who knows the linguistic system of a foreign language and the Brazilian Portuguese language, not being, in this case, a professional translator. This point disfavors the readability of texts, that is, the translated instrument and its interpretation by participants become ambiguous or confused, due to the lack of comprehension in the Portuguese language itself in the document. When proposing the translation in the Brazilian Portuguese language of the protocol Measure of Processes of Care-56 (MPOC-56), produced in Canada in order to verify the attendance of patients by professionals and the therapy Centre from the perspective of parents and, specially, to Speech and Language area, the analysis of readability allows the translator not only to justify his/her translation, but also to make it more available to public in general a semantic construction not to occur mistakes on validated instrument and contributing to be a relevant protocol not only to Health, but also to the Scientific Translation. Therefore, the aim of this study was to translate and to verify the readability of the questionnaire translated into the Brazilian Portuguese. For this study, a methodological research was used in order to obtain and organize documents to translate the instrument. By means of brainstorming step, it was possible to conclude that one professional translator is enough to translate and to do the back translation and, by consulting experts in a certain area can contribute to Brazilian Heath Area to improve validation of protocols or to translate Brazilian protocols to another foreign language.

Keywords: Translation. Back-translation. MPOC-56. Readability. 



\section{LISTA DE FIGURAS}

Figura 1 O ofício do tradutor e suas experiências........................................ 36

Figura 2 Método de tradução de Brislin et al............................................. 62

Figura 3 Processo da retrotradução de Brislin et al.................................... 63

Figura 4 Etapas do processo de tradução e adaptação de protocolos de testes psicométricos de acordo com a atualização do Projeto do

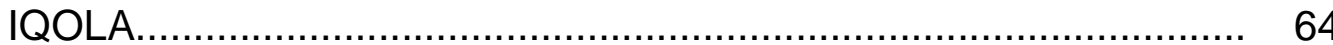

Figura 5 Processo da tradução, adaptação, retrotradução, análise dos perito e pré-teste criados por Beaton et al.

Figura 6 Etapas do processo de tradução e adaptação elaborados por Wang e Lee (2006) .................................................................. 67

Figura 7 Esquema elementar da comunicação para a análise do discurso.... 83

Figura 8 Processo do brainstorming para a versão final da tradução ............. 99 



\section{LISTA DE GRÁFICOS}

Gráfico 1 Número de traduções e adaptações de instrumentos para a Língua Portuguesa Brasileira na área da Fonoaudiologia.......................... 39

Gráfico 2 Autores mencionados no processo tradutório.................................. 60

Gráfico 3 Descrição da metodologia do processo tradutório nos artigos.......... 82

Gráfico 4 Procedimentos teóricos aplicados à tradução................................. 137 



\section{LISTA DE TABELAS}

Tabela 1 Resultados das considerações do primeiro perito............................ 101

Tabela 2 Resultados da análise do segundo perito …................................... 109

Tabela 3 Consenso sobre a tradução do questionário na etapa do brainstorming....................................................................... 117

Tabela 4 Versão final do protocolo pela pesquisadora................................... 125

Tabela 5 Comparativo entre o original e a tradução final............................... 129 



\section{LISTA DE QUADROS}

Quadro 1 Tradução e adaptação de protocolos na área da Fonoaudiologia de 2000 a 2017 e suas respectivas metodologias de tradução para o português brasileiro.................................................................. 40

Quadro 2 Estudos realizados com o instrumento MPOC-56.......................... 77

Quadro 3 Procedimentos técnicos de tradução elaborados por Barbosa (2004) 



\section{LISTA DE ABREVIATURA E SIGLAS}

MPOC

PB

ELF

IT-MAIS

PEACH

FAPI

HISQUI

FAPCI

IFLF

HHIA

EAT-10

THI

LAST

CCIPP

TVQ: MTF

DASH

SSQ

SWAL-QOL

SWAL-CARE

Voiss

MASA

OASES-A

QPV

VFI

TOPL-2

TNL

TSA

PINT

YANS

QSV-P

TEACH

AIADH
Measure of Processes of Care

Português Brasileiro

Early Listening Function

Infant-Toddler: Meaningful Auditory Integration Scale

Parent's Evaluation of Aural/Oral Performance of Children

Functional Auditory Performance Indicators

Hearing Implant Sound Quality Index

Functioning after Pediatric Cochlear Implantation

Índice de Facilidade de Leitura de Flesch

Hearing Handicap Inventory for Adults

Eating Assessment Tool - 10

Tinnitus Handicap Inventory

The Language Screening Test

Children with Cochlear Implants: Parent's Perspectives

Transgender Voice Questionnaire for Male to Female

Detailed Assessment of Speed of Handwriting

Speech, Spatial and Qualities of Hearing Scale

Quality of Life in Swallowing Disorders

Quality of Care in Swallowing Disorders

Voice Symptom Scale

Mann Assessment of Swallowing Ability

Overall Assessment of the Speaker's Experience of Stuttering

Questionário de Performance Vocal

Vocal Fatigue Index

Test of Pragmatic Language 2

Test of Narrative Language

Test Sintaxix de Aguado

Phrases in Noise Test

Youth Attitude to Noise Scale

Questionário de Sintomas Vocais Pediátrico

Teachers' Evaluation of Aural/Oral Performance of Children

Amsterdam Inventory Auditory Disability and Handicap 


$\begin{array}{ll}\text { SECEL } & \text { Self-Evaluation of Communication Experiences after } \\ \text { IQOLA } & \text { Laryngectomy } \\ \text { SF-36 } & \text { International Quality of Life Assessment Project } \\ \text { US } & \text { United States } \\ \text { T1 } & \text { Translation 1 } \\ \text { T2 } & \text { Translation 2 } \\ \text { BT1 } & \text { Back translation 1 } \\ \text { BT2 } & \text { Back translation 2 } \\ \text { IWH } & \text { Institute for Work and Health } \\ \text { HSQ } & \text { High School Questionnaire: Profile of Experiences } \\ \text { ISPOR } & \text { International Society For Pharmacoeconomics and Outcomes } \\ & \text { Research } \\ \text { MAPT } & \text { Multiattribute Arthritis Priositisation } \\ \text { EORTC } & \text { European Organisation for Research and Treatment of Cancer } \\ \text { OMS } & \text { Organização Mundial de Saúde } \\ \text { MPOC-SP } & \text { Measure of Processes of Care - Service Providers }\end{array}$





\section{SUMÁRIO}

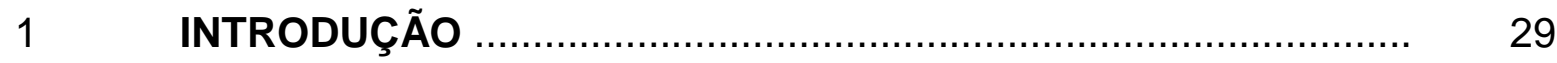

2 REVISÃO DE LITERATURA …................................................. 33

$2.1 \quad$ O PROCESSO DA TRADUÇÃO ……........................................... 33

2.2 O PROCESSO DA TRADUÇÃO DE PROTOCOLOS ...................... 37

$2.3 \quad$ PROTOCOLOS TRADUZIDOS NA FONOAUDIOLOGIA ................ 38

$2.4 \quad$ METODOLOGIAS DE TRADUÇÃO ……….............................. 61

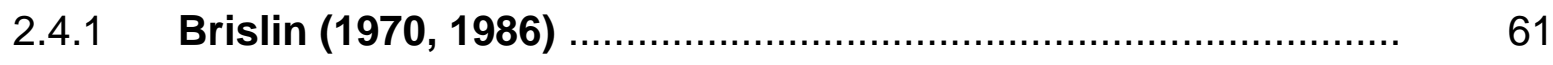

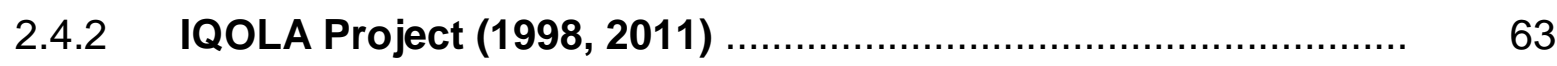

2.4.3 Guillemin et al. e Beaton et al. ...................................... 65

2.4.4 Wang, Lee e Fetzer (2006) ....................................... 67



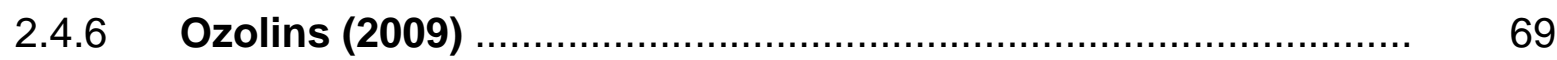

2.4.7 Coulthard (2013) ................................................................. 71

2.5 O PROTOCOLO .................................................... 72

2.5.1 Descrição do instrumento ........................................... 74

2.5.2 Estudos realizados com o MPOC-56 …......................................

2.6 MEDICÃO DA INTELIGIBILIDADE DE PROTOCOLOS .................. 83

$3 \quad$ PROPOSIÇÃO ........................................................................ 87

$4 \quad$ MATERIAL E MÉTODOS …........................................................ 91

$4.1 \quad$ TIPO DE ESTUDO ……........................................................ 91

4.2 METODOLOGIA DO PROCESSO TRADUTÓRIO ........................... 91

4.2.1 Passo 1: Tradução do inglês para o português ........................... 92

4.2.2 Passo 2: Consulta ao comitê de peritos ...................................... 92

4.2.3 Passo 3: Comparação entre o original e a tradução ................... 92

4.3 MEDIÇÃO DA INTELIGIBILIDADE DOS TEXTOS …...................... 93

4.3.1 Brainstorming: avaliação da tradução ……………………...... 93

4.3.2 Análise comparativa ............................................................... 94

4.3.3 A elaboração da versão final ........................................................ 95

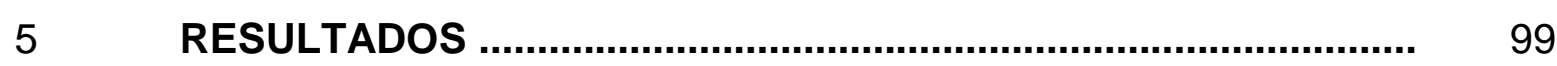

5.1 CONSIDERAÇÕES DOS PERITOS E DA PESQUISADORA ......... 100

5.2 ANÁLISE COMPARATIVA ............................................................ 129 


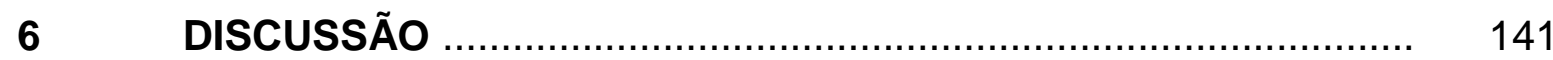

6.1 O PROCESSO DE TRADUÇÃO SEM A RETROTRADUÇÃO ......... 141

6.2 O BRAINSTORMING E A INTELIGIBILIDADE ............................ 143

6.3 ANÁLISE COMPARATIVA ........................................................ 143

$7 \quad$ CONSIDERAÇÕES FINAIS …................................................ 147

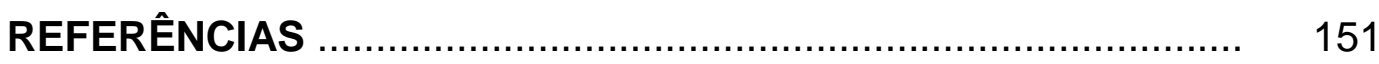

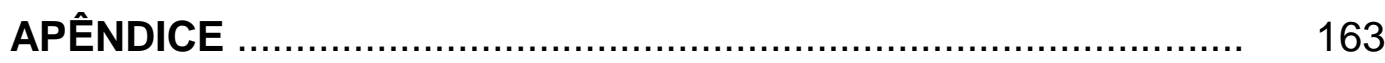

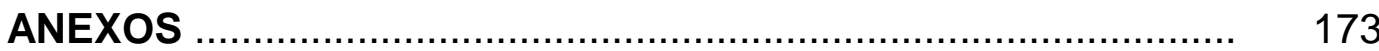



1 Introdução 



\section{INTRODUÇÃO}

A produção de instrumentos avaliativos elaborados no Brasil para pesquisas na área da Saúde ainda é exígua, em especial no que tange a área da Fonoaudiologia/ Audiologia, na qual este estudo se insere. A maioria dos protocolos é traduzida para a Língua Portuguesa e a procura por indivíduos que dominem o idioma estrangeiro é grande, em particular a língua inglesa. Entretanto, para que a tradução alcance seu objetivo máximo, que é a comunicação, isto é, a efetivação do envio e da recepção da mensagem, é necessário que esta se torne inteligível para o receptor. Partindo desse pressuposto, ao avaliar o processo de tradução presente na maioria dos protocolos internacionais, notou-se a inclusão (ou a criação) de uma etapa chamada pelos pesquisadores de retrotradução. No âmbito da saúde e para esses pesquisadores, a retrotradução consiste na versão (geralmente mais de uma) do protocolo do texto traduzido para o idioma de origem, com a finalidade de apurar possíveis equívocos na tradução realizada.

Dessa forma, com a finalidade de analisar e compreender o procedimento tradutório por parte de um tradutor apenas e com o brainstorming constituído por dois profissionais fonoaudiólogos e conhecedores da língua inglesa, o instrumento Measure of Processes of Care (MPOC-56) foi traduzido para o Português Brasileiro. Mediante a tradução desse protocolo, que tem como objetivo avaliar, sob a perspectiva dos pais, o tratamento recebido pelo (a) filho (a) tanto por parte dos profissionais quanto pelo centro de reabilitação, o questionário não se destina a um público determinado para ser aplicado, nem a uma área específica, podendo, assim, ser adaptado à área da Fonoaudiologia ou para a Audiologia, programa no qual este estudo está inserido.

Relacionado ao instrumento MPOC-56, este foi traduzido em sua forma completa, pois o mesmo possui uma forma abreviada, o MPOC-20. O instrumento busca avaliar os serviços prestados pela equipe ao paciente por parte da família e, de acordo com pesquisadores, a aplicação do Measures of Processes of Cares (MPOC-56) torna-se um instrumento eficiente na avaliação dos serviços e cuidados recebidos pela criança sob os critérios dos pais. Por ser um instrumento comprovado como eficiente por meio de inúmeros estudos (elencados nesta pesquisa), a tradução para a língua portuguesa e a inteligibilidade do questionário possibilitará avaliar, em nosso território, a satisfação dos pais dessas crianças e adolescentes 
não somente pela perspectiva dos pais, como também pelo próprio centro de tratamento, com o objetivo de melhorar a habilitação e a reabilitação dos pacientes. O processo tradutório, nesse caso, é composto por elementos gramaticais, semânticos e culturais, e relacionados à área da qual o instrumento será traduzido, passando por algumas etapas até sua validação.

Desse modo, esse questionário, composto por 56 perguntas fechadas, permite uma devolutiva tanto para os pais quanto para os profissionais sobre a satisfação ou não com os serviços prestados por essa equipe multidisciplinar, contribuindo, de forma efetiva, para o processo terapêutico do paciente.

Portanto, o escopo desta pesquisa consistiu em traduzir e adaptar o instrumento para a língua portuguesa brasileira, por um tradutor profissional e verificar a inteligibilidade do instrumento junto ao grupo de discussão (etapa do brainstorming) formado por peritos em Fonoaudiologia. A metodologia empregada será a pesquisa bibliográfica e documental (por meio da leitura e da tradução do instrumento). 
2 Revisão de Literatura 



\section{REVISÃO DE LITERATURA}

A revisão de literatura foi dividida em quatro etapas. No primeiro momento foi executada a pesquisa bibliográfica sobre o processo de tradução científica, com o propósito de posicionar o leitor sobre a tradução para fins específicos, isto é, para a área científica. Em seguida, foi abordada a tradução de protocolos, que é uma prática bem recorrente especialmente na área da saúde.

Em um terceiro momento, foi analisada a tradução de protocolos na área da Fonoaudiologia/ Audiologia e os respectivos profissionais utilizados para o processo de tradução e adaptação. Ainda nesse momento, foi demonstrada, por meio de gráficos, a insuficiência de instrumentos traduzidos para as respectivas áreas e a relação de autores utilizados no procedimento metodológico da tradução. Após esse momento, foi feita a descrição do protocolo a ser utilizado no estudo Measure of Processes of Care - (MPOC-56), bem como o objetivo e os princípios para o estabelecimento de um programa de intervenção centrado na família desenvolvido pelos pesquisadores, com a intenção de verificar a percepção dos pais e/ou responsáveis quanto ao tratamento recebido pela paciente no centro de reabilitação.

Ao final, foi elucidado o aspecto da medição da inteligibilidade pautados no quesito coerência e coesão textual por meio da análise contrastiva segundo Barbosa (2004).

\subsection{0 processo da tradução}

O tradutor deve adotar posturas profissionais e éticas que condizem com a obra a ser traduzida, além do compromisso em traduzir de acordo com o público alvo.

Desse modo, ao tradutor é atribuída a tarefa de encontrar "na língua de chegada, os elementos linguísticos, contextuais e culturais, permitindo-Ihe restituir um texto que pode ser funcional na cultura receptora" (CHANUT, 2012, p. 59).

Portanto, ao realizar uma tradução, Grunwald e Goldfarb (2006) afirmam que, em um processo comum, o tradutor traduz um texto e, para publicação, o editor revisa a tradução e faz correções. Ainda de acordo com os autores (2006), ao considerar traduções do inglês para a língua portuguesa ou espanhola, os dois 
idiomas possuem diferentes estruturas gramaticais que podem refletir ou não na inteligibilidade do texto. De acordo com Venuti (2004), a invisibilidade do tradutor reflete na qualidade da tradução e, consequentemente, na inteligibilidade do texto traduzido.

As traduções para qualquer idioma no campo científico e, mais precisamente, da saúde, são consideradas por pesquisadores como "tradução e adaptação cultural". No entanto, para Venuti (2007), os termos tradução e adaptação são completamente diferentes em relação a um texto. Na concepção de Venuti (2007), a tradução permite o resgate não só do texto original, como também possibilita interpretações diferentes do texto. A respeito da adaptação, Venuti (2007) também enfatiza que esta se afasta do original e, durante esse processo, existem vários tipos de revisão e manipulação.

Desse modo, um fator comum sobre a tradução é que palavras culturalmente marcadas podem conter informação sobre o país, a cultura e as características sociais do texto de partida (exotização) ou da tradução. Um texto elaborado em outra língua e cultura faz referências às pessoas, objetos e instituições que não são facilmente encontrados na cultura de chegada. Essas referências, familiares ao leitor da língua de partida, muitas vezes não tem significado para o leitor da língua de chegada. Cabe, então, ao tradutor, encontrar uma solução para tais referências (HATJE - FAGGION, 2011, p. 73).

Portanto, para Jakobson (1971),

[...] toda experiência cognitiva pode ser traduzida e classificada em qualquer língua existente. Onde houver uma deficiência, a terminologia poderá ser modificada por empréstimos, calcos, neologismos, transferências semânticas e, finalmente, por circunlóquios. (p. 67)

Destarte, Aubert (2001) menciona em seu estudo que o tradutor é o profissional capaz de dominar as técnicas relacionadas ao ato tradutório, pois pertence a um grupo de usuários de fontes terminológicas de todo o tipo (p. 42 (grifos meus).

A ideia de levar o tradutor em formação a desenvolver estratégias de tradução está imbuída do espírito de conscientizá-lo da complexidade do processo tradutório e da necessidade de monitorar suas ações e examinar com cuidado as decisões tomadas ao longo do processo tradutório. [...] $\mathrm{O}$ processo de tradução que aqui propomos aplica-se tanto ao reconhecimento da complexa rede de inter-relações subjacentes ao ato de 
traduzir, como também à própria concepção da tarefa tradutória. (ALVES; MAGALHÃES; PAGANO, 2003, p. 07)

Essa perspectiva corresponde também aos dizeres de Hermans (2007), que, em sua pesquisa, reflete a prática do tradutor como 'nunca somente traduzir'. Esse panorama se refere não somente em relação aos termos técnicos e científicos, mas também abarca toda uma composição de estruturação lexical e semântica dentro do processo tradutório da qual o tradutor deve ter pleno domínio. Portanto, não existe somente a transposição de idiomas e culturas, é necessária erudição para $o$ ato tradutório (grifos meus).

O primeiro e mais óbvio dos requisitos de qualquer tradutor é que tenha
conhecimento satisfatório de língua de partida. Não basta que ele seja
capaz de compreender o sentido geral do texto, ou que tenha o hábito de
consultar dicionários (o que terá de fazer de qualquer modo). Ele deverá
entender não somente o conteúdo óbvio da mensagem, mas também as
sutilezas de significado, o valor emotivo significativo das palavras e as
características estilísticas que determinam o "sabor e sentimento" da
mensagem [...]. Ainda mais importante do que o conhecimento dos recursos
da língua de partida é o controle completo da língua de chegada. [...] [N]ão
há substituto para o domínio pleno da língua de chegada. (PAGURA, 2003,
p. 230)

O processo de tradução constitui, então, de acordo com Robinson (2002) em: 1- Traduzir (ato primeiro, intuitivo); 2- Revisar (pensar no que fez, examinar reações, comparar, editar, e 3- Sublimar (assimilar o que aprendeu nesse processo e transformá-lo em um processo natural.

Já para Azenha Jr. (1999), nesse processo de tradução devem ser considerados os critérios que norteiam tais escolhas do tradutor: só a justificativa desses critérios é capaz de garantir alguma objetividade e, por conseguinte, um grau mínimo de aceitabilidade científica. 
Figura 10 ofício do Tradutor e suas experiências.

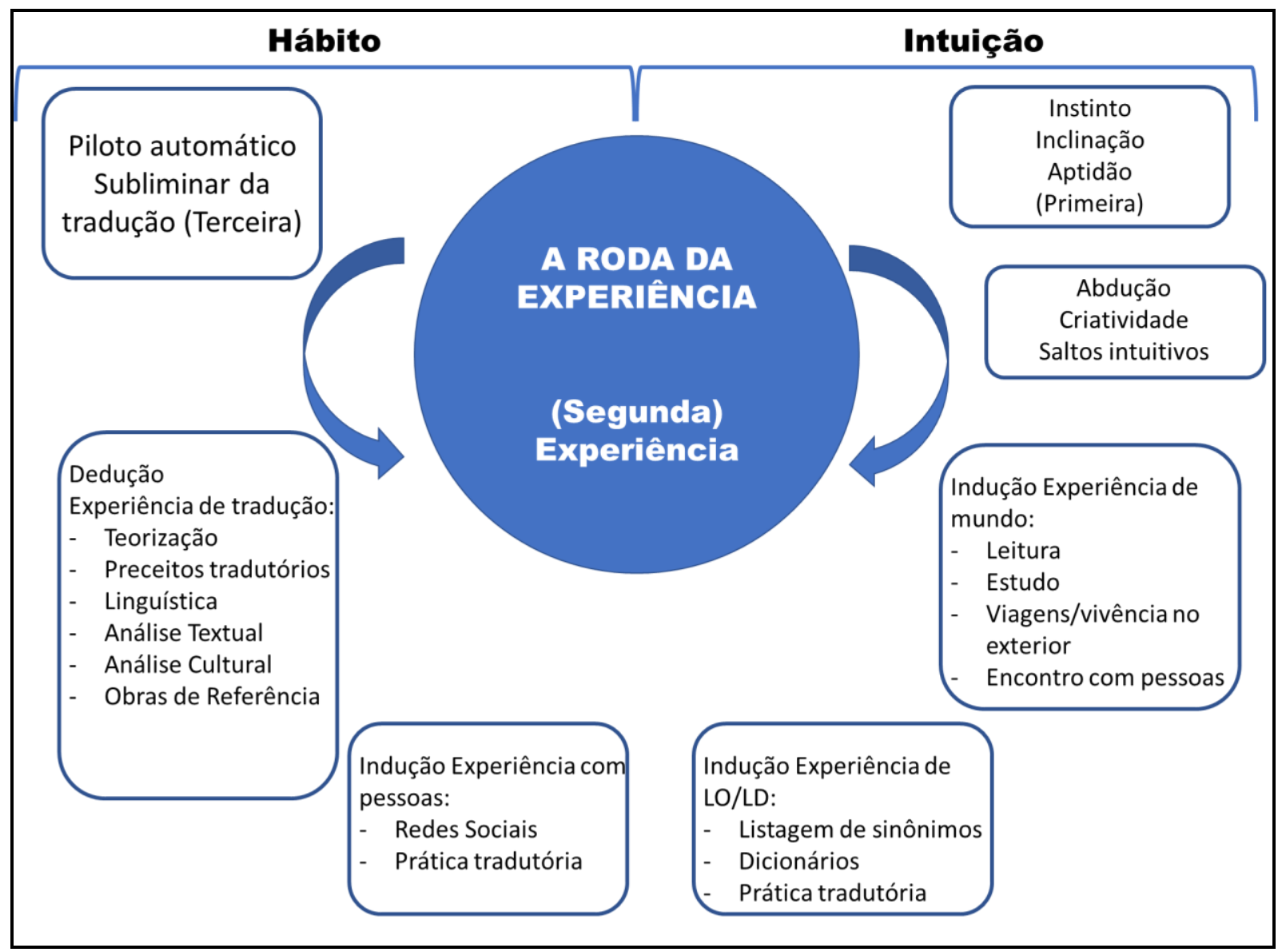

Fonte: Robinson (2002, p. 148)

Para ilustrar o que foi mencionado, Paiva (2004) cita cinco habilidades que um tradutor deve ter:

1) Linguística, isto é, deve compreender a língua de partida e exprimir-se com fluência na língua de chegada;

2) Tradutológica, isto é, ter capacidade de apreender o sentido de um texto, de o transmitir sem o alterar na língua de chegada, evitando as interferências;

3) Metodológica, isto é, ter capacidade para se documentar sobre qualquer assunto e assimilar a terminologia;

4) Multidisciplinar, isto é, ter capacidade para traduzir textos de disciplinas básicas, como economia, informática, direito e outras; 
5) Técnica, isto é, ter capacidade para utilizar diversas técnicas e ferramentas de ajuda à tradução, tais como tratamento de texto, bancos terminológicos, etc.

Dessa forma, a transculturação deve considerar todas as variáveis (grau de interferência de um ou vários profissionais durante os processos de revisão e de preparação do texto final) e muitas outras que estão intrinsecamente ligadas a uma realidade histórico-cultural e são condicionadas por normas sociais e de uso linguístico sujeitos a constantes alterações nas diferentes comunidades e em diferentes momentos de tempo.

Portanto, em virtude do apresentado até aqui, para esta pesquisa serão aplicadas algumas sugestões de pesquisadores como Coulthard (2013) e Ozolins (2009) sobre a eliminação da retrotradução no processo tradutório enfatizando a importância do conhecimento do tradutor tanto das técnicas quanto de linguagens específicas da tradução científica concernentes às práticas obtidas durante a graduação.

\subsection{O processo da tradução de protocolos}

A elaboração de protocolos na área da saúde e a utilização dos mesmos por parte dos profissionais no que concerne à coleta de dados em pesquisas propiciam não somente estudar a realidade que condiz com o paciente, mas também verificar a eficácia de tratamentos, posturas e direcionamentos que serão realizados por esses profissionais a partir da aplicação de um questionário advindo de um protocolo. Entretanto, a maioria dos protocolos tem como país de origem os Estados Unidos, além de países europeus os quais, ao serem aplicados por pesquisadores aqui no Brasil, necessitam, previamente, de sua validação em língua portuguesa.

Desse modo, de acordo com Giusti e Befi-Lopes (2008), a carência na produção de protocolos brasileiros propicia a prática de tradução de instrumentos internacionais, a qual vem crescendo ultimamente de acordo com a 5th International Conference on Psychological and Educational Test Adaptation across Language and Cultures, realizada em Bruxelas, Bélgica, em 2006. Ainda de acordo com as autoras, a tradução e adaptação cultural é uma saída encontrada pelos pesquisadores brasileiros; entretanto, deve ser criteriosa e aplicada com cautela, uma vez que irá originar outro instrumento. 
Nessa perspectiva, o processo de tradução desses protocolos abarca uma variedade de técnicas profissionais às quais o tradutor profissional é submetido

isto é, desde a tradução inicial até o texto final, e essa perfaz a transculturação, culminando na validação do protocolo na língua de chegada. Entretanto, é importante mencionar que, nesse processo dentro da tradução na área da Saúde, o texto original passa por dois ou mais tradutores, como a finalidade de certificar que a tradução está mesmo de acordo (COUTHARD, 2013).

Contudo, não existe tradução perfeita, e, nos dizeres de Jakobson (1971),

se uma tradução cumpre os seus objetivos, é considerada satisfatória, é boa, mesmo que para outros usuários, com diferentes objetivos, ela seja considerada má. Assim, pelo fato de alguns usuários exigirem traduções literais, por exemplo, espalha-se a ideia falsa de que uma tradução nãoliteral não é tradução; da mesma forma, pelo fato de alguns usuários exigirem somente equivalência semântica (ou seja, tradução só do sentido), propaga-se a falsa ideia de que uma tradução literal não é tradução. (p. 9)

Portanto, nota-se que o sentido de um texto não está centrado nem no autor, nem no texto e nem no leitor. A tradução é o resultado de uma negociação entre os três fatores envolvidos.

\subsection{Protocolos traduzidos na Fonoaudiologia}

Na perspectiva deste estudo e de sua aplicabilidade, inicialmente, na área da Fonoaudiologia, foi realizado um estudo com os protocolos, como forma de este estudo contribuir com a área e pela pesquisadora fazer parte do programa do mestrado na referida área. Por meio dos estudos dos protocolos traduzidos encontrados, foi possível verificar que, ainda são, na grande maioria, de origem internacional, corroborando, com o estudo de Giusti e Befi-Lopes (2008), que afirmam que a prática da tradução e adaptação desses materiais ainda é um viés para a realização de pesquisas nessa área.

Ao mencionar a tradução e adaptação na área da Fonoaudiologia, segundo Harkness e Schoua-Glusberg (1998), ainda não existem guias ou parâmetros suficientes para a realização da tradução e adaptação de instrumentos/ questionários, apesar das sugestões propostas, inicialmente, por Guillemin, Bombardier e Beaton (1993). Outro fator apontado pelos pesquisadores é a necessidade de o tradutor possuir conhecimento específico e adequado de acordo 
com o material que traduzirá, como protocolos, e esse apontamento também está presente no campo dos estudos de tradução.

Dessa forma, a tabela a seguir corresponde aos estudos encontrados na área da fonoaudiologia que mencionam o aspecto da metodologia utilizada para 0 processo de tradução e adaptação do instrumento, com a finalidade de realizar um panorama, também, sobre a relevância da metodologia utilizada para a tradução de um protocolo na área da Fonoaudiologia. Para a realização das buscas, usaram-se os descritores "speech language pathology" e "cross-cultural translation" e "portuguese". Também foi considerado como critério de inclusão pesquisas relacionadas somente à área de Fonoaudiologia (e Audiologia) e de instrumentos traduzidos para a língua portuguesa brasileira. As pesquisas foram realizadas nos portais PubMed, LILACS e SciELO. O gráfico abaixo mostra as porcentagens dos artigos encontrados em cada portal.

Gráfico 1 Número de traduções e adaptações de instrumentos para a Língua Portuguesa Brasileira na área da Fonoaudiologia entre 1997 a 2017.

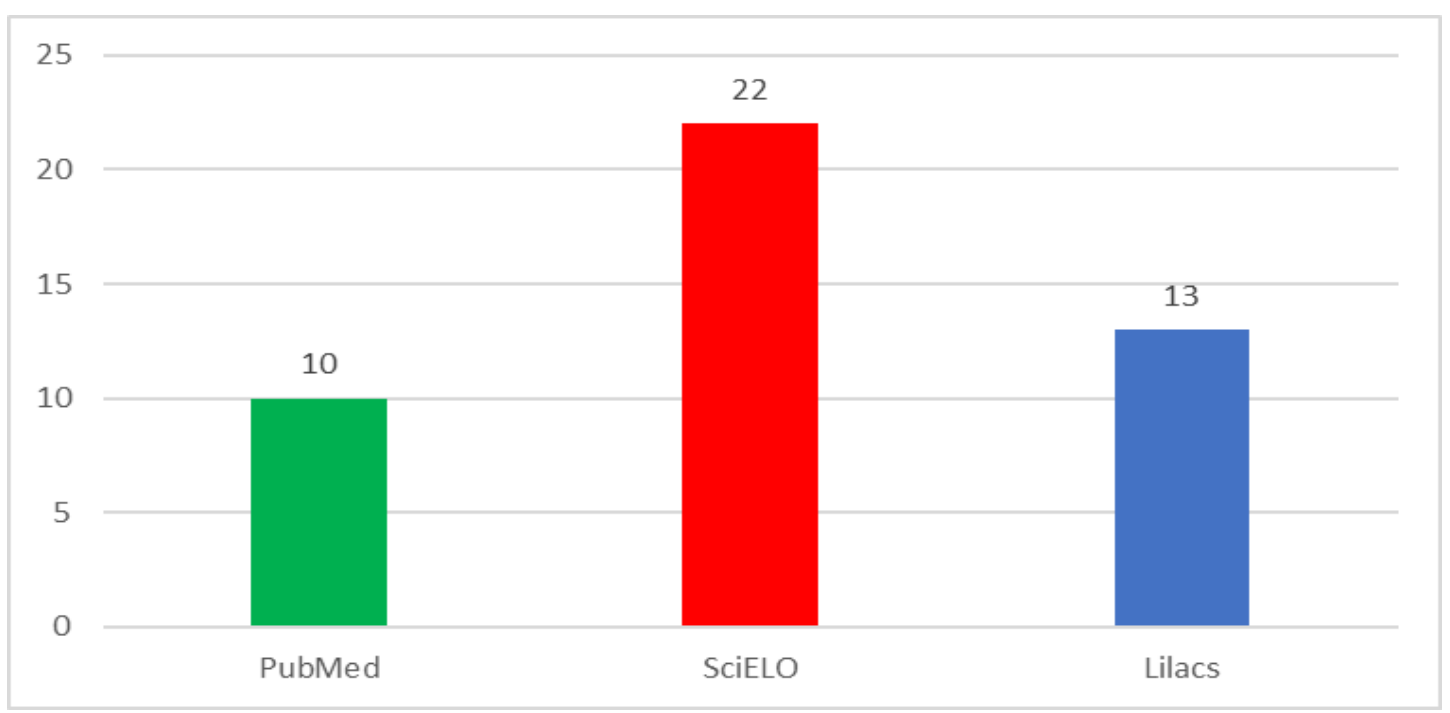

Fonte: Elaborado pela autora (2017)

A seguir, no Quadro 1, encontram-se as traduções e adaptações encontradas, organizadas pelo ano de publicação, e com a descrição da metodologia de tradução utilizada. 
Quadro 1 Tradução e adaptação de protocolos na área da Fonoaudiologia de 2000 a 2017 e suas respectivas metodologias de tradução para o português brasileiro.

\begin{tabular}{|c|c|c|c|c|}
\hline Título & Autores/ano & Protocolo & Processo da tradução & $\begin{array}{c}\text { Metodologia de } \\
\text { tradução }\end{array}$ \\
\hline $\begin{array}{l}\text { Procedimento } \\
\text { para a Avaliação } \\
\text { de Crianças } \\
\text { Deficientes } \\
\text { Auditivas } \\
\text { Profundas } \\
\end{array}$ & $\begin{array}{l}\text { Bevilacqua, } \\
\text { Tech (1996) }\end{array}$ & $\begin{array}{l}\text { Glendonald } \\
\text { Auditory } \\
\text { Screening } \\
\text { Procedure } \\
\text { (GASP, Words } \\
\text { and Sentences) } \\
\end{array}$ & Não foi mencionado o processo tradutório. & $\begin{array}{l}\text { Não foi mencionado no } \\
\text { estudo quais os } \\
\text { embasamentos teóricos } \\
\text { para o processo tradutório } \\
\text { do protocolo. }\end{array}$ \\
\hline IT-MAIS & $\begin{array}{l}\text { Castiquini } \\
\text { (1998) }\end{array}$ & $\begin{array}{l}\text { Meaningful } \\
\text { Auditory } \\
\text { Integration } \\
\text { Scale (MAIS) }\end{array}$ & Não foi mencionado o processo tradutório. & $\begin{array}{l}\text { Não foi mencionado no } \\
\text { estudo quais } \\
\text { embasamentos teóricos da } \\
\text { literatura dos estudos de } \\
\text { tradução para o processo } \\
\text { tradutório do protocolo. }\end{array}$ \\
\hline $\begin{array}{l}\text { Teste } \quad \text { de } \\
\text { Avaliação da } \\
\text { Capacidade } \\
\text { Auditiva Mínima } \\
\text { (TACAM) }\end{array}$ & $\begin{array}{l}\text { Orlandi, } \\
\text { Bevilacqua } \\
(1999)\end{array}$ & $\begin{array}{l}\text { Early Speech } \\
\text { Perception Test: } \\
\text { ESP }\end{array}$ & Não foi mencionado o processo tradutório. & $\begin{array}{l}\text { Não foi mencionado no } \\
\text { estudo quais os } \\
\text { embasamentos teóricos } \\
\text { para o processo tradutório } \\
\text { do protocolo. }\end{array}$ \\
\hline $\begin{array}{l}\text { Tinnitus handicap } \\
\text { inventory: } \\
\text { adaptação } \\
\text { cultural para o } \\
\text { Português } \\
\text { brasileiro }\end{array}$ & $\begin{array}{l}\text { Ferreira et al. } \\
(2005)\end{array}$ & $\begin{array}{l}\text { Tinnitus } \\
\text { Handicap } \\
\text { Inventory (THI) }\end{array}$ & $\begin{array}{l}\text { A adaptação cultural do THI (Newman et al., 1996) seguiu as etapas } \\
\text { indicadas por Guillemin et al. (1993), que incluem a tradução do idioma } \\
\text { Inglês para o Português, adaptação lingüística e revisão das } \\
\text { equivalências gramatical e idiomática. Realizou-se, também, a avaliação } \\
\text { das reprodutibilidades inter e intra-pesquisadores deste questionário. }\end{array}$ & Guillemin et al. (1993). \\
\hline $\begin{array}{l}\text { Versão } \\
\text { do } \\
\text { Handicap Dizzineiness } \\
\text { Inventory }\end{array}$ & $\begin{array}{l}\text { Castro et al. } \\
(2007)\end{array}$ & $\begin{array}{l}\text { Dizziness } \\
\text { handicap } \\
\text { inventory }\end{array}$ & $\begin{array}{l}\text { O questionário foi distribuído para três professores de Inglês, fluentes } \\
\text { nesse idioma. Os três documentos resultantes foram analisados por um } \\
\text { grupo revisor constituído por dois médicos e uma fonoaudióloga } \\
\text { (brasileiros, conhecedores com fluência da língua inglesa), que, por } \\
\text { consenso, reduziram as diferenças encontradas nas traduções. Revisão } \\
\text { da equivalência gramatical e idiomática: o DH brasileiro foi } \\
\text { encaminhado para três outros tradutores, de mesma condição } \\
\text { linguística e cultural dos primeiros. A estes tradutores foi solicitado }\end{array}$ & $\begin{array}{l}\text { A adaptação cultural do } \\
\text { DHI seguiu as etapas } \\
\text { indicadas por Guillemin et } \\
\text { al. (1993). }\end{array}$ \\
\hline
\end{tabular}


continuação

\begin{tabular}{|c|c|c|c|c|}
\hline $\begin{array}{l}\text { Adaptação para o } \\
\text { português brasileiro } \\
\text { do questionário: } \\
\text { Youth Attitude to } \\
\text { Noise Scale } \\
\text { (YANS) }\end{array}$ & $\begin{array}{l}\text { Zocoli, Morata } \\
\text { e Marques } \\
(2009)\end{array}$ & $\begin{array}{l}\text { Youth } \text { Attitude to } \\
\text { Noiser Scale } \\
\text { (YANS) }\end{array}$ & $\begin{array}{l}\text { Foi solicitado a um professor bilíngue para que o mesmo } \\
\text { traduzisse o questionário do inglês para o português. De } \\
\text { posse da tradução, a etapa seguinte foi levar o questionário já } \\
\text { traduzido para que profissionais da área (duas fonoaudiólogas } \\
\text { e um otorrinolaringologista), brasileiros, com fluência na } \\
\text { Língua Inglesa, para analisarem os documentos. Estes não } \\
\text { encontraram diferenças significativas nas traduções. Também } \\
\text { foi avaliada a equivalência semântica (gramática e realizar } \\
\text { nova versão para o idioma Inglês. As três versões resultantes } \\
\text { submeteram-se à apreciação do mesmo grupo revisor, que } \\
\text { criou uma nova versão em inglês. }\end{array}$ & $\begin{array}{l}\text { Não são mencionados na } \\
\text { pesquisa autores referentes à } \\
\text { metodologia utilizada no processo } \\
\text { tradutório. }\end{array}$ \\
\hline $\begin{array}{l}\text { Early } \quad \text { Listening } \\
\text { Function (ELF): } \\
\text { adaptação para a } \\
\text { língua portuguesa }\end{array}$ & $\begin{array}{l}\text { OSHIMA et al. } \\
(2010)\end{array}$ & $\begin{array}{l}\text { Early Listening } \\
\text { Function }(E L F)\end{array}$ & $\begin{array}{l}\text { - Tradução simples do questionário (dois tradutores-intérpretes) } \\
\text { - Adaptação linguística (revisão feita por duas fonoaudiólogas } \\
\text { brasileiras, fluentes na língua inglesa) } \\
\text { - Revisão das equivalências gramatical e idiomática (traduções } \\
\text { reversas, encaminhadas para outros dois tradutores } \\
\text { diferentes dos primeiros para uma nova versão em língua } \\
\text { inglesa do protocolo revisado). } \\
\text { - Adaptação cultural: Estabelecer uma equivalência cultural } \\
\text { entre as versões do inglês e do português, e que tenha } \\
\text { como parâmetro } 80 \% \text { de compreensão da população } \\
\text { avaliada. }\end{array}$ & $\begin{array}{l}\text { Não foi mencionado no estudo } \\
\text { quais os embasamentos teóricos } \\
\text { para o processo tradutório do } \\
\text { protocolo. }\end{array}$ \\
\hline
\end{tabular}


continuação

\begin{tabular}{|c|c|c|c|c|}
\hline $\begin{array}{l}\text { FM Listening } \\
\text { Evaluation For } \\
\text { Children: Adaptação } \\
\text { Para A Língua } \\
\text { Portuguesa }\end{array}$ & $\begin{array}{l}\text { Jacob et } \\
(2010)\end{array}$ & $\begin{array}{lr}\text { FM Listening } \\
\text { Evaluation } \quad \text { for } \\
\text { Children }\end{array}$ & $\begin{array}{l}\text { Adaptação cultural } \\
\text { A tradução e adaptação cultural do questionário } \\
\text { FM Listening Evaluation for Children (JOHNSON, } \\
2003 \text { apud GABBARD, 2004) seguiram as etapas } \\
\text { indicadas por Guillemin, Bombardier e Beaton } \\
\text { (1993), Ferreira et al. (2005), Giusti e Befi-Lopes } \\
\text { (2008), como descrito a seguir: } \\
\text { Tradução do questionário para o idioma } \\
\text { Português } \\
\text { Adaptação linguística } \\
\text { Revisão das equivalências gramatical e } \\
\text { idiomática (traduções reversas) } \\
\text { Adaptação cultural } \\
\text { A equivalência cultural é estabelecida se não } \\
\text { forem observadas dificuldades de compreensão } \\
\text { das questões elaboradas ou dos termos } \\
\text { utilizados, por, no mínimo, } 80 \% \text { da população } \\
\text { avaliada. }\end{array}$ & $\begin{array}{l}\text { Não foi mencionado no estudo } \\
\text { quais os embasamentos teóricos } \\
\text { da literatura dos estudos de } \\
\text { tradução para o processo tradutório } \\
\text { do protocolo. }\end{array}$ \\
\hline \begin{tabular}{lr}
\multicolumn{2}{l}{ Adaptação } \\
Transcultural & Do \\
Questionário & \\
Teachers' Evaluation \\
of Aural/ Oral \\
Performance \\
Children (TEACH)
\end{tabular} & $\begin{array}{l}\text { Lara, Melo, } \\
\text { Mecca (2011) }\end{array}$ & $\begin{array}{l}\text { Teachers' } \\
\text { Evaluation of Aural/ } \\
\text { Oral Performance } \\
\text { of } \quad \text { Children } \\
(T E A C H)\end{array}$ & $\begin{array}{l}\text { Tradução do questionário para o idioma } \\
\text { Português (fase 1), adaptação linguística (fase 2), } \\
\text { revisão gramatical e idiomática (fase 3) e } \\
\text { adaptação cultural (fase 4). Na fase } 1 \\
\text { participaram três tradutores-intérpretes da língua } \\
\text { inglesa. As três traduções foram encaminhadas } \\
\text { para três fonoaudiólogos especialistas em } \\
\text { Audiologia, para avaliação do conteúdo (fase 2). } \\
\text { Os profissionais foram orientados para que as } \\
\text { três traduções fossem analisadas. A cópia da } \\
\text { versão final do TEACH em Português, foi } \\
\text { encaminhada para três outros tradutores- } \\
\text { intérpretes de inglês e os mesmos realizaram } \\
\text { uma nova versão do instrumento para o idioma } \\
\text { Inglês. Para adaptação cultural (fase 4), o } \\
\text { questionário foi aplicado em sete professores de } \\
\text { crianças deficientes auditivas. }\end{array}$ & $\begin{array}{l}\text { Não são mencionados na pesquisa } \\
\text { autores referentes à metodologia } \\
\text { utilizada no processo tradutório. }\end{array}$ \\
\hline
\end{tabular}


continuação

\begin{tabular}{|c|c|c|c|c|}
\hline $\begin{array}{l}\text { Adaptação } \\
\text { transcultural de um } \\
\text { instrumento de } \\
\text { Avaliação do Handicap } \\
\text { auditivoraro } \\
\text { portadores de Perda } \\
\text { auditiva induzida pelo } \\
\text { ruído ocupacional }\end{array}$ & $\begin{array}{l}\text { Holanda, Lima e } \\
\text { Figueroa (2011) }\end{array}$ & $\begin{array}{ll}\text { Hearing } & \text { Disability } \\
\text { and } & \text { Handicap } \\
\text { Scale } & \end{array}$ & $\begin{array}{l}\text { A análise da equivalência semântica baseou- } \\
\text { se no método proposto por Reichenheim; } \\
\text { Moraes; Hasselman (2000) e Moraes, Hasse } \\
\text { Imann e Reichenheim (2002), incluindo cinco } \\
\text { etapas consecutivas: 1) tradução do instrumento } \\
\text { original, 2) retradução, 3) apreciação formal de } \\
\text { equivalência, 4) Pré-teste com amostra de } \\
\text { conveniência e 5) crítica final por especialistas na } \\
\text { área com elaboração da versão final. }\end{array}$ & 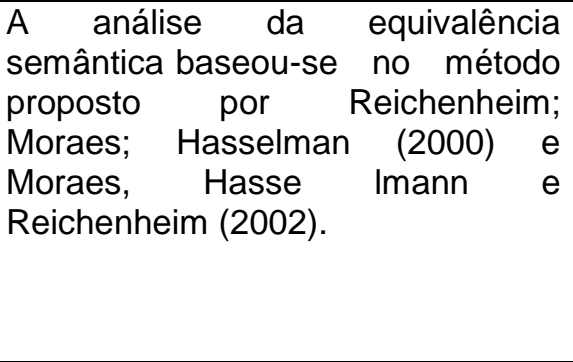 \\
\hline $\begin{array}{l}\text { VALIDAÇÃO } \\
\text { VERSÃO } \\
\text { BRASILEIRA DA } \\
\text { VOICE SYMPTOM } \\
\text { SCALE - VoiSS }\end{array}$ & Moreti (2011) & $\begin{array}{l}\text { VOICE SYMPTOM } \\
\text { SCALE - VoISS }\end{array}$ & $\begin{array}{l}\text { Tradução do instrumento: o questionário Voice } \\
\text { Symptom Scale - VoiSS foi inicialmente traduzido } \\
\text { para a língua portuguesa por duas } \\
\text { fonoaudiólogas, bilíngues, professoras de inglês, } \\
\text { brasileiras, cientes do objetivo desta pesquisa. } \\
\text { Tais traduções foram comparadas pelas } \\
\text { tradutoras e pelos pesquisadores do estudo. Em } \\
\text { seguida, ela foi comparada ao instrumento } \\
\text { original e as discrepâncias existentes foram } \\
\text { analisadas e discutidas por um comitê composto } \\
\text { por cinco fonoaudiólogos especialistas em voz, } \\
\text { com proficiência na língua inglesa e da mesma } \\
\text { forma que na etapa anterior, realizaram } \\
\text { mudanças por consenso, produzindo um } \\
\text { protocolo final, chamado Escala de Sintomas } \\
\text { Vocais - ESV. O protocolo foi aplicado em duas } \\
\text { ocasiões em } 86 \text { pacientes com queixa vocal, em } \\
\text { um intervalo de no mínimo } 2 \text { e máximo } 14 \text { dias, } \\
\text { para o teste de confiabilidade. }\end{array}$ & $\begin{array}{l}\text { Critérios recomendados pelo } \\
\text { Comitê do Conselho Científico da } \\
\text { Associação de Resultados Médicos } \\
\text { (Scientific Advisory Committee of } \\
\text { the Medical Outcomes Trust, 2002) }\end{array}$ \\
\hline
\end{tabular}


continuação

\begin{tabular}{|c|c|c|c|c|}
\hline $\begin{array}{lr}\text { Validade } & \mathrm{e} \\
\text { confiabilidade } & \text { do } \\
\text { questionário } & \text { de } \\
\text { handicap auditivo para } \\
\text { adultos }\end{array}$ & $\begin{array}{l}\text { Aiello, Lima e } \\
\text { Ferrari (2011) }\end{array}$ & $\begin{array}{l}\text { Hearing Handicap } \\
\text { Inventory for Adults } \\
\text { - HHIA }\end{array}$ & $\begin{array}{l}\text { Inicialmente, foi calculado o Índice de Facilidade } \\
\text { de Leitura de Flesch (IFLF) para cada pergunta } \\
\text { do questionário, a fim de avaliar o nível de } \\
\text { dificuldade para a leitura baseado no } \\
\text { comprimento das palavras e frases. O IFLF avalia } \\
\text { o grau de facilidade de leitura dos textos em uma } \\
\text { escala percentual. A escala é composta por sete } \\
\text { níveis, variando de "muito fácil" (pontuações entre } \\
90 \text { a 100\%) a "muito difícil" (pontuações entre } 0 \text { a } \\
30 \% \text { ) }\end{array}$ & $\begin{array}{l}\text { Não há relato sobre a metodologia } \\
\text { adotada para a tradução do } \\
\text { questionário. }\end{array}$ \\
\hline $\begin{array}{l}\text { Indicadores } r \\
\text { Performance } \\
\text { Funcional Auditiva } \\
\text { (FAPI): aplicação em } \\
\text { crianças brasileiras }\end{array}$ & Ferreira, 2011 & $\begin{array}{l}\text { Functional Auditory } \\
\text { Performance } \\
\text { Indicators (FAPI) }\end{array}$ & $\begin{array}{l}\text { - Tradução simples do questionário (dois } \\
\text { tradutores-intérpretes) } \\
\text { - Adaptação linguística (revisão feita por dois } \\
\text { audiologistas, fluentes na língua inglesa) } \\
\text { - Revisão das equivalências gramatical e } \\
\text { idiomática (traduções reversas, encaminhadas } \\
\text { para outros dois tradutores diferentes dos } \\
\text { primeiros para uma nova versão em língua } \\
\text { inglesa do protocolo revisado). } \\
\text { Adaptação cultural: Estabelecer uma equivalência } \\
\text { cultural entre as versões do inglês e do } \\
\text { português, e que tenha como parâmetro } 80 \% \\
\text { de compreensão da população avaliada. }\end{array}$ & $\begin{array}{l}\text { Não é mencionado no trabalho qual } \\
\text { metodologia quanto a tradução foi } \\
\text { utilizada, apesar de constar nas } \\
\text { referências os nomes de Guillemin, } \\
\text { Bombardier e Beaton (1993). }\end{array}$ \\
\hline $\begin{array}{l}\text { Crianças com implante } \\
\text { coclear: habilidades } \\
\text { comunicativas e } \\
\text { qualidade de vida }\end{array}$ & $\begin{array}{l}\text { Fortunato- } \\
\text { Tavares et al. } \\
(2012)\end{array}$ & $\begin{array}{l}\text { Children with } \\
\text { cochlear implants: } \\
\text { parent's } \\
\text { perspectives } \\
\text { (CCIPP) }\end{array}$ & $\begin{array}{l}\text { Primeiramente, duas fonoaudiólogas falantes } \\
\text { nativas do Português Brasileiro e fluentes em } \\
\text { Inglês realizaram duas traduções e adaptações } \\
\text { culturais do questionário Children with Cochlear } \\
\text { Implants: Parent's Perspectives para o Português } \\
\text { Brasileiro. Uma versão unificada do questionário } \\
\text { em Português Brasileiro foi realizada pelas duas } \\
\text { fonoaudiólogas após a comparação das duas } \\
\text { traduções. }\end{array}$ & $\begin{array}{l}\text { Não foi feita menção na pesquisa } \\
\text { sobre quais teóricos ou } \\
\text { pesquisadores embasaram a } \\
\text { escolha do método do processo de } \\
\text { tradução. }\end{array}$ \\
\hline
\end{tabular}


continuação

\begin{tabular}{|c|c|c|c|c|}
\hline $\begin{array}{l}\text { Versão brasileira do } \\
\text { protocolo Overall } \\
\text { Assessment of the } \\
\text { Speaker's Experience } \\
\text { of Stuttering - Adults } \\
\text { (OASES-A) }\end{array}$ & $\begin{array}{l}\text { Bragatto et al. } \\
(2012)\end{array}$ & $\begin{array}{l}\text { Overall } \\
\text { Assessment of the } \\
\text { Speaker's } \\
\text { Experience of } \\
\text { Stuttering - Adults } \\
\text { (OASES-A) }\end{array}$ & $\begin{array}{l}\text { A primeira fase constou da tradução e adaptação } \\
\text { do conteúdo do OASES-A para o Português } \\
\text { Brasileiro. Na segunda fase, avaliou-se a sua } \\
\text { concordância depois de traduzido. } \\
\text { Posteriormente, foi realizada a aplicação do } \\
\text { instrumento OASES-A já traduzido para o } \\
\text { Português Brasileiro, aos indivíduos da amostra. }\end{array}$ & $\begin{array}{l}\text { No decorrer da pesquisa não é } \\
\text { mencionado escolhidos para a } \\
\text { metodologia de tradução, } \\
\text { entretanto, nas referências contam } \\
\text { os estudos de Guillemin, } \\
\text { Bombardier e Beaton (1993) e } \\
\text { Beaton et al. (2000). }\end{array}$ \\
\hline $\begin{array}{ll}\text { Validação } & \text { do } \\
\text { Questionário } & \text { de } \\
\text { Performance } & \text { Vocal no } \\
\text { Brasil } & \end{array}$ & $\begin{array}{l}\text { Paulinelli, Gama } \\
\text { e Behlau (2012) }\end{array}$ & $\begin{array}{l}\text { Vocal Performance } \\
\text { Questionnaire }\end{array}$ & $\begin{array}{l}\text { Primeiramente foram analisados os aspectos de } \\
\text { modelo conceitual e de medida, confiabilidade, } \\
\text { validade, sensibilidade, interpretabilidade e } \\
\text { demanda de administração e resposta. O } \\
\text { questionário foi traduzido e também } \\
\text { retrotraduzido por duas fonoaudiólogas fluentes } \\
\text { na língua. As versões foram comparadas e a } \\
\text { versão em Português do questionário foi gerada, } \\
\text { recebendo o nome Questionário de Performance } \\
\text { Vocal - QPV. }\end{array}$ & $\begin{array}{l}\text { Foram seguidos os passos do } \\
\text { Scientific Advisory Committee of } \\
\text { the Medical Outcomes Trust - SAC }\end{array}$ \\
\hline $\begin{array}{l}\text { Qualidade de Vida em } \\
\text { Voz na População } \\
\text { Pediátrica: validação } \\
\text { da versão brasileira do } \\
\text { Protocolo Qualidade } \\
\text { de Vida em Voz } \\
\text { Pediátrico }\end{array}$ & $\begin{array}{l}\text { Ribeiro, Paula e } \\
\text { Behlau (2013) }\end{array}$ & $\begin{array}{l}\text { Pediatric Voice- } \\
\text { Related Quality-of- } \\
\text { Life Survey }\end{array}$ & $\begin{array}{l}\text { 1. tradução e adaptação linguística e cultural com } \\
\text { brasileiros bilíngues fonoaudiólogos e não } \\
\text { fonoaudiólogos que realizaram a tradução e } \\
\text { retrotradução; } \\
\text { 2. avaliação da equivalência cultural com a } \\
\text { aplicação da versão traduzida em um grupo de } \\
\text { participantes com alteração vocal; } \\
\text { 3. aplicação do protocolo na sua versão final com } \\
\text { as questões definitivas do instrumento em } \\
\text { participantes com e sem queixa de alteração } \\
\text { vocal; } \\
\text { 4. avaliação vocal pelos pais/responsáveis de } \\
\text { indivíduos com e sem queixa de alteração vocal; } \\
\text { 5. análise estatística descritiva demográfica e } \\
\text { clínica da população; } \\
\text { 7. medidas psicométricas de validade; } \\
\text { 8. confiabilidade; } \\
\text { 9. reprodutibilidade; } \\
\text { 10. sensibilidade ao tratamento. }\end{array}$ & $\begin{array}{l}\text { A validação do protocolo PVRQoL } \\
\text { foi executada em dez etapas } \\
\text { realizadas na validação brasileira } \\
\text { da versão adulto do protocolo } \\
\text { Qualidade de Vida em Voz - QVVe } \\
\text { de acordo com as normas } \\
\text { propostas pelo Comitê do Conselho } \\
\text { Científico da Associação de } \\
\text { Resultados Médicos (Scientific } \\
\text { Advisory Commitee of the Medical } \\
\text { Outcomes Trust). }\end{array}$ \\
\hline
\end{tabular}


continuação

\begin{tabular}{|c|c|c|c|c|}
\hline $\begin{array}{l}\text { Questionário } \\
\text { C.H.A.P.S. - Children's } \\
\text { Auditory Performance } \\
\text { Scale: tradução e } \\
\text { adaptação para o } \\
\text { português brasileiro }\end{array}$ & $\begin{array}{l}\text { Donadon et al. } \\
(2013\end{array}$ & $\begin{array}{l}\text { Children's Auditory } \\
\text { Performance Scale }\end{array}$ & $\begin{array}{l}\text { Um novo processo de tradução e adaptação do } \\
\text { questionário foi realizado seguindo as etapas de } \\
\text { tradução inicial; síntese das traduções; } \\
\text { retrotradução; comitê de especialistas e versão } \\
\text { final do questionário. }\end{array}$ & Beaton et al. (2000). \\
\hline $\begin{array}{l}\text { Tradução e adaptação } \\
\text { transcultural para o } \\
\text { português brasileiro do } \\
\text { teste Children's } \\
\text { Communication } \\
\text { Checklist-2 }\end{array}$ & $\begin{array}{lll}\begin{array}{l}\text { Costa } \\
(2013)\end{array} & \text { et } & \text { al. } \\
\end{array}$ & $\begin{array}{l}\text { Children's } \\
\text { Communication } \\
\text { Checklist-2 }\end{array}$ & $\begin{array}{l}\text { Preparação - foi solicitada autorização da } \\
\text { autora do teste original. } \\
\text { - Tradução - foram realizadas duas traduçães } \\
\text { independentes por dois tradutores diferentes, } \\
\text { ambos fluentes. } \\
\text { - Conciliação - T1 e T2 foram conciliadas por } \\
\text { uma terceira pessoa, gerando a versão T3 - } \\
\text { tradução de consenso. } \\
\text { - Retrotradução (back translation) - a versão T3 } \\
\text { do teste foi novamente traduzida para o inglês a } \\
\text { fim de ser comparada com a versão original e } \\
\text { verificação da confiabilidade. } \\
\text { - Revisão da retrotradução - a autora do teste } \\
\text { original ajudou na revisão do teste para maior } \\
\text { confiabilidade na tradução. } \\
\text { - Aplicação do teste e realização da versão final. }\end{array}$ & $\begin{array}{l}\text { A tradução } \text { e adaptação } \\
\text { transcultural seguiram as as } \\
\text { recomendações da International } \\
\text { Society for Pharmacoeconomics } \\
\text { and Outcomes Research (ISPOR) }\end{array}$ \\
\hline $\begin{array}{l}\text { Validação do protocolo } \\
\text { Perfil de Participação } \\
\text { e Atividades Vocais no } \\
\text { Brasil }\end{array}$ & $\begin{array}{l}\text { Ricarte, Oliveira } \\
\text { e Behlau (2013) }\end{array}$ & $\begin{array}{l}\text { Vocal Activity and } \\
\text { Participation Profile } \\
\text { (VAPP) }\end{array}$ & $\begin{array}{l}\text { instrumento foi submetido à adaptação } \\
\text { linguística/cultural, validação, confiabilidade, } \\
\text { reprodutibilidade e sensibilidade ao tratamento. }\end{array}$ & $\begin{array}{l}\text { A tradução e validação foram } \\
\text { realizadas seguindo as orientações } \\
\text { do Scientific Advisory Committee of } \\
\text { Medical Outcomes Trust. }\end{array}$ \\
\hline $\begin{array}{l}\text { Tradução e adaptação } \\
\text { transcultural do } \\
\text { Northwestern } \\
\text { Dysphagia Patient } \\
\text { Check Sheet para o } \\
\text { português brasileiro }\end{array}$ & $\begin{array}{lll}\text { Junior } & \text { et } & \text { al. } \\
(2013) & & \\
\end{array}$ & $\begin{array}{l}\text { Northwestern } \\
\text { Dysphagia Patient } \\
\text { Check Sheet }\end{array}$ & $\begin{array}{l}\text { A etapa de tradução foi realizada por dois } \\
\text { fonoaudiólogos bilíngues, seguida da } \\
\text { retrotradução por uma nativa bilíngue da língua } \\
\text { materna e, posteriormente, pela comparação das } \\
\text { três versões por um comitê formado por três } \\
\text { fonoaudiólogos. A versão final do NDPCS foi } \\
\text { inicialmente aplicada em } 35 \text { voluntários na faixa } \\
\text { etária entre } 62 \text { e } 92 \text { anos. }\end{array}$ & $\begin{array}{l}\text { Os critérios para tradução e } \\
\text { adaptação transcultural seguiram } \\
\text { quatro etapas, propostas por Peters } \\
\text { e Passchier (2006) }\end{array}$ \\
\hline
\end{tabular}


continuação

\begin{tabular}{|c|c|c|c|c|}
\hline $\begin{array}{l}\text { Adaptação cultural e } \\
\text { validação do "The } \\
\text { Language Screening } \\
\text { Test- LAST" versões a } \\
\text { e b para o português } \\
\text { do Brasil }\end{array}$ & Ramos, 2013 & $\begin{array}{l}\text { The Language } \\
\text { Screening Test - } \\
\text { (LAST) }\end{array}$ & $\begin{array}{l}\text { 10 Estágio: Tradutores independentes geram } \\
\text { versões T1 e T2) } \\
2^{\circ} \text { Estágio: Um tradutor sintetiza as traduções } \\
\text { gerando uma outra tradução. } \\
3^{\circ} \text { Estágio: Retrotradução. Um quarto tradutor } \\
\text { traduz o instrumento para a língua original. } \\
4^{\circ} \text { Estágio: Aplicação do questionário } \\
5^{\circ} \text { Estágio: Consenso com o comitê } \\
\text { multidisciplinar para gerar a última versão. } \\
\text { 6 Estágio: Pré-teste da versão final. }\end{array}$ & $\begin{array}{l}\text { Segue-se os estágios de tradução, } \\
\text { adaptação cultural e validação de } \\
\text { instrumento de avaliação conforme } \\
\text { os padrões exigidos } \\
\text { internacionalmente e orientações } \\
\text { existentes em publicações aceitas } \\
\text { e específicas sobre essa temática } \\
\text { (Guillemin et al., 1993; Alexandre e } \\
\text { Guirardello, 2002; Beaton et al., } \\
\text { 2002). }\end{array}$ \\
\hline $\begin{array}{l}\text { Equivalência cultural } \\
\text { da versão brasileira do } \\
\text { Eating Assessment } \\
\text { Tool-EAT-10 }\end{array}$ & $\begin{array}{l}\text { Gonçalves, } \\
\text { Remaili, Behlau } \\
(2013)\end{array}$ & $\begin{array}{l}\text { Eating Assessment } \\
\text { Tool (EAT-10) }\end{array}$ & $\begin{array}{l}\text { O questionário foi traduzido para a língua } \\
\text { portuguesa por duas fonoaudiólogas brasileiras } \\
\text { bilíngues, cientes do objetivo desta pesquisa, que } \\
\text { realizaram a tradução conceitual, evitando o uso } \\
\text { literal das palavras ou frases. A seguir, as duas } \\
\text { traduções foram comparadas e compiladas em } \\
\text { uma única. A retrotradução foi efetuada por uma } \\
\text { terceira fonoaudióloga, brasileira, bilíngue, } \\
\text { professora de inglês, que não participou da etapa } \\
\text { anterior. A tradução e a retrotradução foram } \\
\text { confrontadas entre si e também em relação ao } \\
\text { conteúdo do instrumento original, sendo que } \\
\text { discrepâncias existentes foram analisadas e } \\
\text { discutidas por um comitê composto por três } \\
\text { fonoaudiólogas especialistas em disfagia, com } \\
\text { proficiência na língua inglesa, que realizaram as } \\
\text { mudanças necessárias por consenso, produzindo } \\
\text { um protocolo final, denominado Instrumento de } \\
\text { Autoavaliação da Alimentação - EAT-10. }\end{array}$ & $\begin{array}{l}\text { Critérios utilizados pelo Scientific } \\
\text { Advisory Committee of Medical } \\
\text { Outcomes. }\end{array}$ \\
\hline
\end{tabular}


continuação

\begin{tabular}{|c|c|c|c|c|}
\hline $\begin{array}{l}\text { Brazilian adaptation off } \\
\text { the Functioning after } \\
\text { Pediatric Cochlear } \\
\text { Implantation (FAPCI): } \\
\text { comparison between } \\
\text { Normal hearing and } \\
\text { cochlear implanted } \\
\text { children }\end{array}$ & $\begin{array}{l}\text { Vassoler e } \\
\text { Cordeiro (2014) }\end{array}$ & $\begin{array}{l}\text { Functioning after } \\
\text { Pediatric Cochlear } \\
\text { Implantation } \\
\text { (FAPCI) }\end{array}$ & $\begin{array}{l}\text { Foi obtida a autorização do autor do instrumento } \\
\text { para a tradução, adaptação e validação do FAPCl } \\
\text { para o PB. O instrumento foi traduzido por um } \\
\text { tradutor profissional conhecedor das duas línguas } \\
\text { e de acordo com o guia estabelecido por Beaton } \\
\text { et al. (2000). Algumas adaptações foram } \\
\text { necessárias com a finalidade da tradução } \\
\text { transcultural, mas a essência do original foi } \\
\text { mantida. A tradução foi enviada a outro tradutor } \\
\text { profissional que não desconhecia o questionário } \\
\text { original para a retrotradução. Foi realizada a } \\
\text { equivalência entre o original e a retrotradução } \\
\text { para que fossem realizadas as modificaçôes } \\
\text { necessárias para a confiabilidade da versão final } \\
\text { do FAPCI-PB. }\end{array}$ & $\begin{array}{l}\text { Apenas o guia sugerido por Beaton } \\
\text { et al. (2000) foi utilizado como } \\
\text { referência para o processo } \\
\text { tradutório descrito no artigo. }\end{array}$ \\
\hline $\begin{array}{l}\text { Tradução e adaptação } \\
\text { cultural brasileira do } \\
\text { Detailed Assessment } \\
\text { of Speed of } \\
\text { Handwriting: } \\
\text { equivalência } \\
\text { conceitual e semântica }\end{array}$ & $\begin{array}{l}\text { Cardoso, } \\
\text { Henderson, } \\
\text { Capellini (2014) }\end{array}$ & $\begin{array}{l}\text { Detailed } \\
\text { Assessment } \\
\text { of Speed } \\
\text { Handwriting } \\
\text { (DASH) }\end{array}$ & $\begin{array}{l}\text { (1) Avaliação de equivalências conceitual e de } \\
\text { itens e (2) Avaliação da equivalência semântica, } \\
\text { que envolveu as etapas de (2a) Tradução, (2b) } \\
\text { Retradução, (2c) Revisão pelo comitê de juízes e } \\
\text { (2d) Pré-teste. }\end{array}$ & $\begin{array}{lcr}\text { São } & \text { mencionados } & \text { os } \\
\text { pesquisadores } & \text { Reichenheim, } \\
\text { Moraes (2007). } & \end{array}$ \\
\hline $\begin{array}{l}\text { Adaptação } \\
\text { Transcultural do } \\
\text { Preschool Language } \\
\text { Assessment } \\
\text { Instrument: Segunda } \\
\text { Edição }\end{array}$ & $\begin{array}{l}\text { Lindau, Rossi e } \\
\text { Giacheti (2014) }\end{array}$ & $\begin{array}{l}\text { Preschool } \\
\text { Language } \\
\text { Assessment } \\
\text { Instrument }\end{array}$ & $\begin{array}{l}\text { O processo de tradução e adaptação desse } \\
\text { instrumento foi realizado em duas etapas - Etapa } \\
1:(1 \mathrm{a}) \text { tradução da versão original para o } \\
\text { Português Brasileiro, (1b) comparação das } \\
\text { versões traduzidas e síntese para uma única } \\
\text { versão em Português, (1c) retrotradução, (1d) } \\
\text { revisão da versão traduzida; e Etapa 2: (2a) } \\
\text { aplicação da versão em Português em um projeto } \\
\text { piloto de } 30 \text { sujeitos e (2b) comparação estatística } \\
\text { dos três grupos etários. }\end{array}$ & $\begin{array}{l}\text { Guillemin, Bombardier, Beaton } \\
\text { (1993) } \\
\text { Herdman, Fox-Rushby, Badia } \\
\text { (1998) } \\
\text { Beaton, Bombardier, Guillemin e } \\
\text { Ferraz (2000) } \\
\text { Wang, Lee, Fetzer (2006) }\end{array}$ \\
\hline
\end{tabular}


continuação

\begin{tabular}{|c|c|c|c|c|}
\hline $\begin{array}{l}\text { Adaptação do teste } \\
\text { Clinical Evaluation of } \\
\text { Language Functions - } \\
\text { 4th Edition para o } \\
\text { Português Brasileiro }\end{array}$ & $\begin{array}{l}\text { Bento-Gaz e } \\
\text { Belfi-Lopes } \\
(2014)\end{array}$ & $\begin{array}{l}\text { Clinical Evaluation } \\
\text { of } \quad \text { Language } \\
\text { Functions }-4 \text { th } \\
\text { Edition }\end{array}$ & $\begin{array}{l}\text { Foram realizadas as seguintes etapas: (1) } \\
\text { tradução direta, (2) tradução inversa, (3) análise } \\
\text { da equivalência teórica, semântica e cultural, (4) } \\
\text { aplicação do teste e (5) versão final da tradução. }\end{array}$ & $\begin{array}{l}\text { A tradução e adaptação do CELF-4 } \\
\text { utilizaram o método já consagrado } \\
\text { em inúmeros estudos e que é } \\
\text { recomendado pela Organização } \\
\text { Mundial de Saúde. }\end{array}$ \\
\hline $\begin{array}{l}\text { Adaptação } \\
\text { transcultural para o } \\
\text { Português Brasileiro } \\
\text { do Teste de } \\
\text { Rastreamento } \\
\text { Western Aphasia } \\
\text { Battery - Revised: um } \\
\text { estudo preliminar }\end{array}$ & $\begin{array}{l}\text { Neves et al. } \\
(2014)\end{array}$ & $\begin{array}{l}\text { Western Aphasia } \\
\text { Battery } \\
\text { - Revised }\end{array}$ & $\begin{array}{l}\text { Etapa 1: equivalência conceitual e de itens } \\
\text { Etapa 2: equivalência semântica: produção de } \\
\text { traduções iniciais por parte dos profissionais da } \\
\text { fonoaudiologia (um que tinha conhecimento do } \\
\text { tema abordado e outro com conhecimento em } \\
\text { inglês) } \\
\text { - Retrotraduções comparação das versões } \\
\text { preliminares com poucas discrepâncias a serem } \\
\text { resolvidas. Foram realizadas por duas } \\
\text { professoras de inglês simultaneamente. } \\
\text { - Aplicação de subtestes para verificar as } \\
\text { adaptações necessárias. } \\
\text { - Revisão dos especialistas } \\
\text { Etapa 3: equivalência operacional: avaliação das } \\
\text { apropriações pelo trio de pesquisadores } \\
\text { - Pré-teste. }\end{array}$ & Reichenheim e Moraes (2007) \\
\hline $\begin{array}{lr}\text { Tradução e } & \text { Adaptação } \\
\text { do } & \text { Amsterdam } \\
\text { Inventory } & \text { Auditory } \\
\text { Disability } & \text { and } \\
\text { Handicap } & \text { (AlADH) } \\
\text { para o } & \text { Português } \\
\text { Brasileiro } & \\
\end{array}$ & $\begin{array}{l}\text { Canavezi } \\
\text { Zanchetta } \\
(2015)\end{array}$ & $\begin{array}{l}\text { Amsterdam } \\
\text { Inventory Auditory } \\
\text { Disability and } \\
\text { Handicap (AIADH) }\end{array}$ & $\begin{array}{l}\text { O processo de tradução e adaptação do AIADH } \\
\text { foi realizado seguindo recomendações da } \\
\text { literatura, divididos em } 3 \text { etapas }(\mathrm{E}) \text { : E1, tradução } \\
\text { do idioma Inglês para o Português, por intérpretes } \\
\text { independentes; E2, retrotradução; E3, formação } \\
\text { do comitê revisor. }\end{array}$ & $\begin{array}{l}\text { Não são mencionados na pesquisa } \\
\text { autores referentes à metodologia } \\
\text { utilizada no processo tradutório. }\end{array}$ \\
\hline
\end{tabular}


continuação

\begin{tabular}{|c|c|c|c|c|}
\hline $\begin{array}{l}\text { Phrases in Noise Test } \\
\text { (PINT): adaptação } \\
\text { cultural para o } \\
\text { português brasileiro e } \\
\text { aplicabilidade na } \\
\text { avaliação do sistema } \\
\text { de frequência } \\
\text { modulada }\end{array}$ & Santos (2015) & $\begin{array}{l}\text { Phrases in Noise } \\
\text { Test (PINT) }\end{array}$ & $\begin{array}{l}\text { Tradução do instrumento original por dois } \\
\text { tradutores independentes. Para a adaptação } \\
\text { linguística duas fonoaudiólogas fluentes no inglês } \\
\text { participaram do grupo revisor. Para a revisão das } \\
\text { equivalências gramatical e idiomática foi realizada } \\
\text { a retrotradução encaminhada a dois tradutores } \\
\text { diferentes. A adaptação cultural foi estabelecida } \\
\text { por meio da equivalência entre as versões } \\
\text { inglesas e portuguesas. }\end{array}$ & $\begin{array}{l}\text { Guillemin, Bombardier e Beaton } \\
(1993)\end{array}$ \\
\hline $\begin{array}{l}\text { Equivalência } \\
\text { psicométrica da } \\
\text { versão brasileira do } \\
\text { Test of Pragmatic } \\
\text { Language } 2 \text { - TOPL-2 }\end{array}$ & $\begin{array}{l}\text { Carvalho, Lúcio } \\
\text { e Ávila (2015) }\end{array}$ & $\begin{array}{l}\text { Test of Pragmatic } \\
\text { Language } 2 \\
\text { TOPL-2 }\end{array}$ & $\begin{array}{l}\text { A tradução foi realizada por uma tradutora } \\
\text { juramentada e aplicada em um grupo de } \\
\text { escolares brasileiros do ensino fundamental. As } \\
\text { respostas coletadas nesse procedimento foram } \\
\text { analisadas e aquelas que apresentaram maior } \\
\text { número de erros foram reanalisadas por três } \\
\text { fonoaudiólogas brasileiras. Para a revisão e } \\
\text { equivalência gramatical e idiomática, o teste foi } \\
\text { enviado a um novo tradutor de inglês que } \\
\text { desconhecia o original, para que fosse feito o } \\
\text { processo inverso, ou seja, sua versão ao inglês, a } \\
\text { qual, comparada ao original, mostrou-se fiel. }\end{array}$ & Beaton et al. (2000). \\
\hline $\begin{array}{l}\text { Tradução transcultural } \\
\text { do protocolo Mann } \\
\text { Assessment of } \\
\text { Swallowing } \\
\text { Ability - MASA para o } \\
\text { português brasileiro }\end{array}$ & $\begin{array}{l}\text { Ribeiro, } \\
\text { Berretin-Félix } \\
(2015)\end{array}$ & $\begin{array}{l}\text { Mann Assessment } \\
\text { of Swallowing } \\
\text { Ability-MASA }\end{array}$ & $\begin{array}{l}\text { Na primeira etapa foram realizadas duas } \\
\text { traduções independentes por duas } \\
\text { fonoaudiólogas bilíngues, que ao final se } \\
\text { reuniram para produzir uma única versão em } \\
\text { português. Esta versão em português ao ser } \\
\text { concluída foi retrotraduzida para o inglês por uma } \\
\text { tradutora, sem conhecimento prévio da versão } \\
\text { original em inglês. Na terceira etapa, uma banca } \\
\text { composta por três fonoaudiólogas bilíngues com } \\
\text { experiência na área foi formada para avaliar as } \\
\text { versões original, traduzida e retrotraduzida e } \\
\text { realizar modificações necessárias } \\
\text { tradução do protocolo. }\end{array}$ & $\begin{array}{l}\text { A proposta de tradução } \\
\text { transcultural foi baseada nas } \\
\text { "recomendações para uma } \\
\text { tradução de alta qualidade", } \\
\text { descrita por Peters e Passchier } \\
(2006) \text {. }\end{array}$ \\
\hline
\end{tabular}


continuação

\begin{tabular}{|c|c|c|c|c|}
\hline $\begin{array}{l}\text { Adaptação cultural do } \\
\text { questionário Speech, } \\
\text { Spatial and Qualities } \\
\text { of Hearing Scale } \\
\text { (SSQ) para o } \\
\text { Português Brasileiro }\end{array}$ & $\begin{array}{l}\text { Gonsalez e } \\
\text { Almeida (2015) }\end{array}$ & $\begin{array}{l}\text { Speech, Spatial } \\
\text { and Qualities of } \\
\text { Hearing Scale } \\
\text { (SSQ) }\end{array}$ & $\begin{array}{l}\text { Na primeira etapa, dois fonoaudiólogos brasileiros, } \\
\text { especialistas na área, fluentes no idioma inglês, } \\
\text { traduziram, individualmente, o questionário. Na } \\
\text { segunda etapa, foi feita a retrotradução por um } \\
\text { falante nativo, bilíngue. Em seguida, um comitê de } \\
\text { especialistas verificou as diferenças entre a versão } \\
\text { original, primeira versão em português e a } \\
\text { retrotradução para o inglês. A terceira etapa, a fase } \\
\text { de pré-teste. Quando identificada dificuldade de } \\
\text { compreensão em determinada questão no período } \\
\text { pré-teste, o comitê de especialistas novamente se } \\
\text { reuniu, revisou e modificou as questões, de forma } \\
\text { que o contexto não fosse alterado. }\end{array}$ & $\begin{array}{l}\text { O questionário SSQ foi traduzido } \\
\text { utilizando-se a metodologia } \\
\text { proposta por Guillemin et al. } \\
\text { (1993) }\end{array}$ \\
\hline $\begin{array}{l}\text { Tradução e avaliação } \\
\text { preliminar da versão } \\
\text { em Português do } \\
\text { Questionário de } \\
\text { Autoavaliação Vocal } \\
\text { para Transexuais de } \\
\text { Homem para Mulher }\end{array}$ & $\begin{array}{l}\text { Santos et al. } \\
(2015)\end{array}$ & $\begin{array}{l}\text { Transgender Voice } \\
\text { Questionnaire for } \\
\text { male to female } \\
\text { Transsexuals }\end{array}$ & $\begin{array}{l}\text { Para a tradução e adaptação do questionário } \\
\text { TVQ: MTF e da ficha demográfica TVQ } \\
\text { Demographics Form- MTF foram seguidos os } \\
\text { estágios: tradução, conciliação, retrotradução, } \\
\text { harmonização e teste piloto. }\end{array}$ & $\begin{array}{l}\text { Foram seguidos os estágios com } \\
\text { base em Wild et al. (2005) e o } \\
\text { Scientific Advisory Committee of } \\
\text { Medical Trust (SAC) }\end{array}$ \\
\hline $\begin{array}{l}\text { Munich Music } \\
\text { Questionnaire: } \\
\text { adaptação para a } \\
\text { língua portuguesa e } \\
\text { aplicação em usuários } \\
\text { de implante coclear }\end{array}$ & $\begin{array}{l}\text { Lopes, } \\
\text { Bevilacqua } \\
\text { Costa (2015) }\end{array}$ & $\begin{array}{l}\text { Munich Music } \\
\text { Questionnaire }\end{array}$ & $\begin{array}{l}\text { O questionário MUMU na versão original em Inglês } \\
\text { foi distribuído para três tradutores-intérpretes } \\
\text { fluentes nessa língua. Em seguida, formou-se o } \\
\text { grupo revisor, o qual foi constituído por duas } \\
\text { fonoaudiólogas brasileiras, fluentes na língua } \\
\text { inglesa. Dessa forma, foi obtido um novo e único } \\
\text { questionário denominado Questionário de Música } \\
\text { de Munique. A próxima etapa constituiu-se da } \\
\text { tradução reversa. O Questionário foi encaminhado } \\
\text { para três outros tradutores. A adaptação cultural } \\
\text { objetivou estabelecer a equivalência cultural entre } \\
\text { as versões nas línguas inglesa e portuguesa do } \\
\text { questionário. A equivalência cultural é estabelecida } \\
\text { quando no mínimo } 80 \% \text { dos indivíduos não } \\
\text { mostram algum tipo de dificuldade para responder } \\
\text { a cada questão formulada. }\end{array}$ & $\begin{array}{l}\text { A tradução e } \text { adaptação cultural } \\
\text { do MUMU seguiram a } \\
\text { metodologia indicada por } \\
\text { Guillemin et al. (1993), que incluiu } \\
\text { a tradução da língua inglesa para } \\
\text { a portuguesa e adaptação } \\
\text { linguística, } \\
\begin{array}{l}\text { equivalência revisão } \\
\text { idiomática e adaptação cultural. }\end{array}\end{array}$ \\
\hline
\end{tabular}

continua 
continuação

\begin{tabular}{|c|c|c|c|c|}
\hline $\begin{array}{l}\text { Adaptação Cultural da } \\
\text { Escala de Qualidade } \\
\text { de Vida Familiar } \\
\text { (Family Quality of Life } \\
\text { Scale) } \\
\text { para o Português } \\
\text { Brasileiro }\end{array}$ & $\begin{array}{l}\text { Jorge, Levy e } \\
\text { Granato (2015) }\end{array}$ & $\begin{array}{l}\text { Family Quality of } \\
\text { Life Scale }\end{array}$ & $\begin{array}{l}\text { Permissão para a tradução para o Português } \\
\text { Brasileiro do instrumento. } \\
\text { Tradução com dois tradutores. } \\
\text { Síntese das duas traduções. } \\
\text { Retrotradução para o inglês. } \\
\text { Revisão pelo comitê para a produção final. }\end{array}$ & $\begin{array}{l}\text { O único embasamento teórico está } \\
\text { pautado no guia estabelecido por } \\
\text { Beaton et al. (2000). }\end{array}$ \\
\hline $\begin{array}{lr}\text { Validação } & \text { do } \\
\text { questionário } & \text { Parent's } \\
\text { Evaluation } & \text { of } \\
\text { Aural/Oral } & \\
\text { Performance } & \text { of } \\
\text { Children - PEACH em } \\
\text { língua portuguesa } \\
\text { brasileira }\end{array}$ & $\begin{array}{l}\text { Levy, } \\
\text { Rodrigues-Sato } \\
\text { (2016) }\end{array}$ & $\begin{array}{l}\text { Parent's } \\
\text { of } \quad \text { Auraluation } \\
\text { Performance of } \\
\text { Children }\end{array}$ & $\begin{array}{l}\text { Tradução e adaptação do questionário por dois } \\
\text { pesquisadores brasileiros; } \\
\text { Após as duas traduções, foi então elaborada uma } \\
\text { única versão } \\
\text { Envio da tradução realizada a uma nativa de } \\
\text { língua inglesa com conhecimento da língua } \\
\text { portuguesa para a retrotradução; } \\
\text { Versão final de acordo com os propósitos dos } \\
\text { pesquisadores brasileiros. }\end{array}$ & $\begin{array}{l}\text { Não foi mencionado no estudo } \\
\text { quais os embasamentos teóricos } \\
\text { da literatura dos estudos de } \\
\text { tradução para o processo tradutório } \\
\text { do protocolo. }\end{array}$ \\
\hline $\begin{array}{l}\text { Tradução e Adaptação } \\
\text { transcultural para o } \\
\text { Português Brasileiro } \\
\text { do Questionário } \\
\text { Hearing Implant Sound } \\
\text { Quality } \quad \text { Index } \\
\text { (HISQUI19) }\end{array}$ & $\begin{array}{l}\text { Caporali et al. } \\
\text { (2016) }\end{array}$ & $\begin{array}{lr}\text { Hearing } & \text { Implant } \\
\text { Sound } & \text { Quality } \\
\text { Index } & (H I S Q U I 19)\end{array}$ & $\begin{array}{l}\text { Equivalência Conceitual e de item: avaliação por } \\
\text { três avaliadores de competência na área da } \\
\text { saúde e reabilitação em implante coclear. } \\
\text { Equivalência Semântica: Foi realizada por meio } \\
\text { de três traduções independentes do original em } \\
\text { inglês para o PB. As três traduções foram } \\
\text { sintetizadas em uma única versão por um quarto } \\
\text { e quinto profissional. Esta versão foi enviada a } \\
\text { um sexto profissional com vivencia na língua } \\
\text { inglesa e conhecedor da língua portuguesa para a } \\
\text { retrotradução que, em seguida, foi comparada à } \\
\text { versão original item por item e no geral. Os } \\
\text { resultados da comparação foram discutidos entre } \\
\text { os profissionais da saúde gerando a versão final } \\
\text { com as modificações. }\end{array}$ & $\begin{array}{l}\text { No processo não são mencionados } \\
\text { teóricos da tradução, em } \\
\text { específico, os relacionados à área } \\
\text { científica, somente que a tradução } \\
\text { e adaptação transcultural seguiu as } \\
\text { sugestões de Beaton et al (2000). }\end{array}$ \\
\hline
\end{tabular}


continuação

\begin{tabular}{|c|c|c|c|c|}
\hline $\begin{array}{l}\text { LittlEars® } \\
\text { Questionário auditivo: } \\
\text { adaptação semântica } \\
\text { e cultural da versão } \\
\text { em } \\
\text { Brasileiro em pais de } \\
\text { crianças com } \\
\text { deficiência auditiva }\end{array}$ & $\begin{array}{l}\text { Leandro et al. } \\
(2016)\end{array}$ & $\begin{array}{l}\text { The LittIEARSA } \\
\text { Auditory } \\
\text { Questionnaire }\end{array}$ & $\begin{array}{l}\text { A primeira etapa do processo de validação do } \\
\text { questionário LittlEars® para o português brasileiro } \\
\text { visou a tradução e adaptação linguística e } \\
\text { cultural, conforme critérios daquele Comitê do } \\
\text { Conselho Científico da Associação de Resultados } \\
\text { Médicos (Scientific Advisory Committee of the } \\
\text { Medical Outcomes Trust). A primeira tradução do } \\
\text { questionário LittlEars } \AA \text { para o português foi de } \\
\text { responsabilidade da empresa Med-El, que } \\
\text { desenvolveu o instrumento, e foi revisado por } \\
\text { profissionais fonoaudiólogos da área. }\end{array}$ & $\begin{array}{l}\text { Comitê do Conselho Científico da } \\
\text { Associação de Resultados Médicos } \\
\text { (Scientific Advisory Committee of } \\
\text { the Medical Outcomes Trust) }\end{array}$ \\
\hline 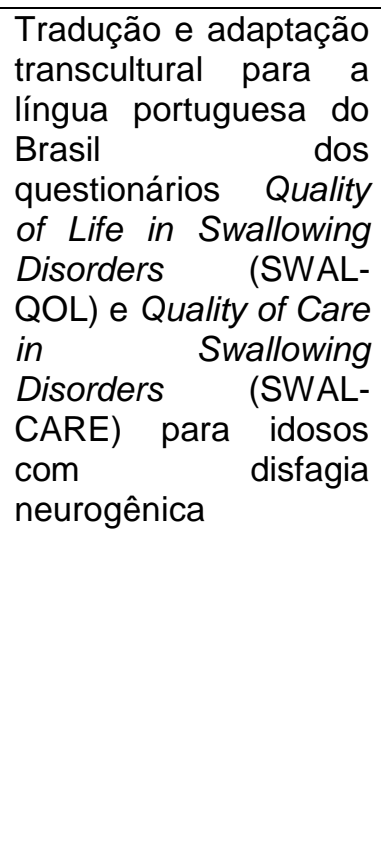 & Felipini (2016) & $\begin{array}{l}\text { Quality of Life in } \\
\text { Swallowing } \\
\text { Disorders (SWAL- } \\
\text { QOL) e Quality of } \\
\text { Care in Swallowing } \\
\text { Disorders (SWAL- } \\
\text { CARE) }\end{array}$ & $\begin{array}{l}\text { Para a tradução e adaptação transcultural foram } \\
\text { considerados seis estágios: (1) traduções, (2) } \\
\text { síntese das traduções, (3) retrotraduções, (4) } \\
\text { comitê de peritos, (5) teste da versão prévia e (6) } \\
\text { submissão dos documentos deste processo para } \\
\text { um comitê de acompanhamento. No primeiro } \\
\text { estágio, duas traduções foram elaboradas por } \\
\text { tradutores distintos; no segundo estágio, essas } \\
\text { duas traduções foram analisadas, e uma versão } \\
\text { síntese foi estabelecida durante uma reunião } \\
\text { entre os tradutores e um juiz neutro; no terceiro } \\
\text { estágio, essa versão síntese foi retrotraduzida } \\
\text { para a língua inglesa por dois falantes de língua } \\
\text { inglesa; no quarto estágio, houve uma nova } \\
\text { reunião envolvendo os dois tradutores, um dos } \\
\text { dois retrotradutores, uma fonoaudióloga, um } \\
\text { perito em Letras e um metodologista que } \\
\text { estabeleceram a versão prévia a ser testada; no } \\
\text { quinto estágio, aconteceram os testes e as } \\
\text { adequações necessárias para que uma versão } \\
\text { final em língua portuguesa fosse estabelecida. }\end{array}$ & Beaton et al. (2000). \\
\hline
\end{tabular}


continuação

\begin{tabular}{|c|c|c|c|c|}
\hline $\begin{array}{l}\text { Tradução e adaptação } \\
\text { cultural do Swallowing } \\
\text { disturbance } \\
\text { questionnaire para o } \\
\text { português-brasileiro }\end{array}$ & $\begin{array}{l}\text { Ayres et al. } \\
(2016)\end{array}$ & $\begin{array}{l}\text { Swallowing } \\
\text { disturbance } \\
\text { Questionnaire }\end{array}$ & $\begin{array}{l}\text { Realizou-se tradução para o português, } \\
\text { retradução para o inglês, análise de confiabilidade } \\
\text { do instrumento, sendo a versão final aplicada aos } \\
\text { participantes e realizado o reteste após duas } \\
\text { semanas. } \\
\text { Selecionou-se os participantes em um } \\
\text { ambulatório de distúrbios do movimento de um } \\
\text { hospital de referência no Rio Grande do Sul }\end{array}$ & $\begin{array}{l}\text { No decorrer da pesquisa não é } \\
\text { mencionado escolhidos para a } \\
\text { metodologia de tradução, } \\
\text { entretanto, nas referências contam } \\
\text { os estudos de Guillemin, } \\
\text { Bombardier e Beaton (1993) }\end{array}$ \\
\hline $\begin{array}{l}\text { TELEGRAM: } \\
\text { contribuição na } \\
\text { indicação na de } \\
\text { tecnologia assistiva } \\
\text { para indivíduos com } \\
\text { deficiência auditiva }\end{array}$ & $\begin{array}{l}\text { Jacob et. Al. } \\
(2016)\end{array}$ & TELEGRAM & $\begin{array}{l}\text { O instrumento na versão original foi distribuído } \\
\text { para dois tradutores-intérpretes de inglês fluentes } \\
\text { nesse idioma, que não se conheciam e não } \\
\text { conheciam o protocolo. O grupo revisor foi } \\
\text { constituído por duas fonoaudiólogas (brasileiras, } \\
\text { conhecedoras com fluência da Língua Inglesa), } \\
\text { que analisaram os dois documentos resultantes e } \\
\text { reduziram as diferenças encontradas nas } \\
\text { traduções, adaptando o texto à cultura brasileira. } \\
\text { Dessa forma, foi obtido um novo inventário } \\
\text { denominado "TELEGRAM". } \\
\text { Para a revisão da equivalência gramatical e } \\
\text { idiomática, uma cópia do protocolo foi } \\
\text { encaminhada para dois outros tradutores. O } \\
\text { mesmo grupo revisor realizou nova avaliação das } \\
\text { duas versões resultantes, comparando-as com a } \\
\text { original em inglês. }\end{array}$ & $\begin{array}{l}\text { Guillemin, Bombardier, Beaton } \\
\text { (1993) }\end{array}$ \\
\hline $\begin{array}{l}\text { Equivalência } \\
\text { psicométrica da } \\
\text { versão brasileira do } \\
\text { Test of Pragmatic } \\
\text { Language } 2 \text { - TOPL-2 }\end{array}$ & $\begin{array}{l}\text { Carvalho, Lúcio } \\
\text { e Ávila (2015) }\end{array}$ & $\begin{array}{l}\text { Test of Pragmatic } \\
\text { Language } 2 \\
\text { TOPL-2 }\end{array}$ & $\begin{array}{l}\text { A tradução foi realizada por uma tradutora } \\
\text { juramentada e aplicada em um grupo de } \\
\text { escolares brasileiros do ensino fundamental. As } \\
\text { respostas coletadas nesse procedimento foram } \\
\text { analisadas e aquelas que apresentaram maior } \\
\text { número de erros foram reanalisadas por três } \\
\text { fonoaudiólogas brasileiras. Para a revisão e } \\
\text { equivalência gramatical e idiomática, o teste foi } \\
\text { enviado a um novo tradutor de inglês que } \\
\text { desconhecia o original, para que fosse feito o } \\
\text { processo inverso, ou seja, sua versão ao inglês, a } \\
\text { qual, comparada ao original, mostrou-se fiel. }\end{array}$ & Beaton et al. (2000). \\
\hline
\end{tabular}


continuação

\begin{tabular}{|c|c|c|c|c|}
\hline $\begin{array}{l}\text { Tradução e adaptação } \\
\text { cultural do Swallowing } \\
\text { disturbance } \\
\text { questionnaire para o } \\
\text { português-brasileiro }\end{array}$ & $\begin{array}{l}\text { Ayres et al. } \\
(2016)\end{array}$ & $\begin{array}{l}\text { Swallowing } \\
\text { disturbance } \\
\text { Questionnaire }\end{array}$ & $\begin{array}{l}\text { Realizou-se tradução para o português, } \\
\text { retradução para o inglês, análise de confiabilidade } \\
\text { do instrumento, sendo a versão final aplicada aos } \\
\text { participantes e realizado o reteste após duas } \\
\text { semanas. } \\
\text { Selecionou-se os participantes em um } \\
\text { ambulatório de distúrbios do movimento de um } \\
\text { hospital de referência no Rio Grande do Sul }\end{array}$ & $\begin{array}{l}\text { No decorrer da pesquisa não é } \\
\text { mencionado escolhidos para a } \\
\text { metodologia de tradução, } \\
\text { entretanto, nas referências contam } \\
\text { os estudos de Guillemin, } \\
\text { Bombardier e Beaton (1993) }\end{array}$ \\
\hline $\begin{array}{l}\text { TELEGRAM: } \\
\text { contribuição na } \\
\text { indicação } \quad \text { de } \\
\text { tecnologia assistiva } \\
\text { para indivíduos com } \\
\text { deficiência auditiva }\end{array}$ & $\begin{array}{l}\text { Jacob et. Al. } \\
(2016)\end{array}$ & TELEGRAM & $\begin{array}{l}\text { O instrumento na versão original foi distribuído } \\
\text { para dois tradutores-intérpretes de inglês fluentes } \\
\text { nesse idioma, que não se conheciam e não } \\
\text { conheciam o protocolo. O grupo revisor foi } \\
\text { constituído por duas fonoaudiólogas (brasileiras, } \\
\text { conhecedoras com fluência da Língua Inglesa), } \\
\text { que analisaram os dois documentos resultantes e } \\
\text { reduziram as diferenças encontradas nas } \\
\text { traduções, adaptando o texto à cultura brasileira. } \\
\text { Dessa forma, foi obtido um novo inventário } \\
\text { denominado "TELEGRAM". } \\
\text { Para a revisão da equivalência gramatical e } \\
\text { idiomática, uma cópia do protocolo foi } \\
\text { encaminhada para dois outros tradutores. O } \\
\text { mesmo grupo revisor realizou nova avaliação das } \\
\text { duas versões resultantes, comparando-as com a } \\
\text { original em inglês. }\end{array}$ & $\begin{array}{l}\text { Guillemin, Bombardier, } \text { Beaton } \\
(1993)\end{array}$ \\
\hline $\begin{array}{l}\text { Equivalência } \\
\text { psicométrica da } \\
\text { versão brasileira do } \\
\text { Test of Pragmatic } \\
\text { Language } 2 \text { - TOPL-2 }\end{array}$ & $\begin{array}{l}\text { Carvalho, Lúcio } \\
\text { e Ávila (2015) }\end{array}$ & $\begin{array}{l}\text { Test of Pragmatic } \\
\text { Language } 2 \\
\text { TOPL-2 }\end{array}$ & $\begin{array}{l}\text { A tradução foi realizada por uma tradutora } \\
\text { juramentada e aplicada em um grupo de } \\
\text { escolares brasileiros do ensino fundamental. As } \\
\text { respostas coletadas nesse procedimento foram } \\
\text { analisadas e aquelas que apresentaram maior } \\
\text { número de erros foram reanalisadas por três } \\
\text { fonoaudiólogas brasileiras. Para a revisão e } \\
\text { equivalência gramatical e idiomática, o teste foi } \\
\text { enviado a um novo tradutor de inglês que } \\
\text { desconhecia o original, para que fosse feito o } \\
\text { processo inverso, ou seja, sua versão ao inglês, a } \\
\text { qual, comparada ao original, mostrou-se fiel. }\end{array}$ & Beaton et al. (2000). \\
\hline
\end{tabular}


continuação

\begin{tabular}{|c|c|c|c|c|}
\hline $\begin{array}{l}\text { Adaptação cultural do } \\
\text { Test of Narrative } \\
\text { Language (TNL) para } \\
\text { o Português Brasileiro }\end{array}$ & 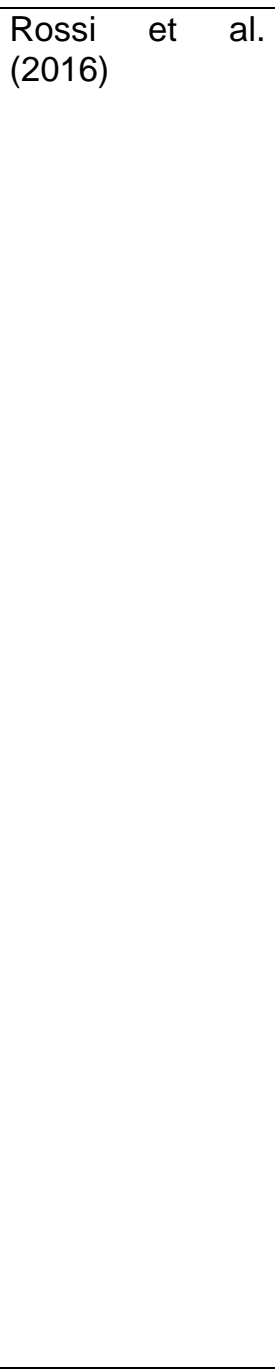 & $\begin{array}{l}\text { Test of Narrative } \\
\text { Language (TNL) }\end{array}$ & $\begin{array}{l}\text { Etapa 1. Tradução da versão original (Inglês) para } \\
\text { a língua-alvo (Português Brasileiro), realizada de } \\
\text { modo independente por dois tradutores bilíngues } \\
\text { e juramentados, gerando duas versões traduzidas } \\
\text { (TNL-PB1 e TNL-PB2). } \\
\text { Etapa 2. Comparação entre as duas versões } \\
\text { traduzidas para identificar a existência de } \\
\text { possíveis discrepâncias entre as versões; } \\
\text { adaptação de itens para avaliação da } \\
\text { equivalência semântica e cultural e discussão } \\
\text { com comitê de especialistas (três fonoaudiólogos } \\
\text { brasileiros) } \\
\text { Etapa 3. Retrotradução da versão síntese do } \\
\text { TNL-PB para a língua original, realizada por um } \\
\text { terceiro tradutor bilíngue e juramentado, não } \\
\text { conhecedor do teste original e do objetivo da } \\
\text { pesquisa. } \\
\text { Etapa } 4 \text {. Comparação entre a versão } \\
\text { retrotraduzida e a versão original do teste para } \\
\text { avaliação da equivalência conceitual, semântica e } \\
\text { cultural entre as versões, realizada pelo comitê de } \\
\text { especialistas (três fonoaudiólogos brasileiros e o } \\
\text { primeiro autor do teste original) para proposição } \\
\text { da versão adaptada pré-final do TNL-PB. Umm } \\
\text { quarto especialista (linguista brasileiro) foi } \\
\text { consultado para situações em que houve maior } \\
\text { dificuldade encontrada na transposição de } \\
\text { conceitos entre a língua de origem do instrumento } \\
\text { e a língua- alvo. } \\
\text { Etapa } 5 \text {. Estudo-piloto com a aplicação da versão } \\
\text { adaptada pré-final do TNL-PB na população-alvo } \\
\text { para verificar e avaliar a equivalência operacional } \\
\text { do teste quanto à sua compreensibilidade, para } \\
\text { gerar a versão final adaptada. }\end{array}$ & $\begin{array}{l}\text { Gjersing, Caplehon e Clausen } \\
(2010) \\
\text { Borsa, Damásio e Bandeira (2012) }\end{array}$ \\
\hline
\end{tabular}


continuação

\begin{tabular}{|c|c|c|c|c|}
\hline $\begin{array}{l}\text { Tradução e adaptação } \\
\text { transcultural do Test } \\
\text { de Sintaxis de Aguado } \\
\text { (TSA) para a língua } \\
\text { portuguesa do Brasil }\end{array}$ & Baggio (2016) & $\begin{array}{l}\text { Test Sintaxix de } \\
\text { Aguado (TSA) }\end{array}$ & $\begin{array}{l}\text { Tradução do teste - duas traduções com a } \\
\text { adaptação (cultural e linguística) por meio de } \\
\text { estratégias tradutórias. As duas traduções } \\
\text { acusaram divergências. } \\
\text { Estágio 2: Revisão de síntese com a presença } \\
\text { dos dois tradutores e mediada por um juiz neutro. } \\
\text { Estágio 3: retrotradução do texto para o idioma } \\
\text { original feita por dois retrotradutores. } \\
\text { Estágio 4: Coleta das informações dos quatro } \\
\text { tradutores responsáveis além do perito na área } \\
\text { da saúde com especialidade em linguagem. } \\
\text { Estágio 5: Estudo piloto (pré-teste) }\end{array}$ & $\begin{array}{l}\text { Guillemin, Bombardier e Beaton } \\
\text { (1993). }\end{array}$ \\
\hline $\begin{array}{l}\text { Equivalência cultural } \\
\text { da versão brasileira do } \\
\text { Questionnaire des } \\
\text { Symptômes Vocaux / } \\
\text { Cross-cultural } \\
\text { adaptation of the } \\
\text { Brazilian version of the } \\
\text { 'Questionnaire Des } \\
\text { Symptômes Vocaux' }\end{array}$ & $\begin{array}{l}\text { Krohling, } \\
\text { Verduyckt, } \\
\text { Behlau (2016) }\end{array}$ & $\begin{array}{l}\text { Questionnaire Des } \\
\text { Symptômes } \\
\text { Vocaux }\end{array}$ & $\begin{array}{l}\text { O instrumento original, em francês, Questionnaire } \\
\text { des Symptômes Vocaux foi traduzido para o } \\
\text { português brasileiro por duas fonoaudiólogas } \\
\text { brasileiras bilíngues, cientes do objetivo da } \\
\text { pesquisa, que realizaram a tradução conceitual. } \\
\text { Posteriormente, procedeu-se à uma } \\
\text { retrotradução, realizada por uma terceira } \\
\text { fonoaudióloga brasileira, bilíngue e professora de } \\
\text { francês, não participante do processo de } \\
\text { tradução. A tradução e a retrotradução foram } \\
\text { comparadas entre si e à versão original do } \\
\text { instrumento, e discutidas com os autores; as } \\
\text { diferenças nos termos utilizados foram analisadas } \\
\text { e modificadas por consenso. }\end{array}$ & $\begin{array}{l}\text { Não são mencionados na pesquisa } \\
\text { autores referentes à metodologia } \\
\text { utilizada no processo tradutório. }\end{array}$ \\
\hline
\end{tabular}


continuação

\begin{tabular}{|c|c|c|c|c|}
\hline $\begin{array}{l}\text { Adaptação } \\
\text { transcultural do } \\
\text { Self-Evaluation of } \\
\text { Communication } \\
\text { Experiences after } \\
\text { Laryngectomy } \\
\text { (SECEL) para o } \\
\text { Português Brasileiro }\end{array}$ & $\begin{array}{l}\text { Fahl e Goulart } \\
(2016)\end{array}$ & $\begin{array}{l}\text { Self-Evaluation of } \\
\text { Communication } \\
\text { Experiences after } \\
\text { Laryngectomy } \\
\text { (SECEL) }\end{array}$ & $\begin{array}{l}\text { Inicialmente, o SECEL foi traduzido do inglês para } \\
\text { o português por um profissional da saúde e por } \\
\text { um professor de inglês com experiência em } \\
\text { tradução, de forma independente. Ambas as } \\
\text { traduções foram semelhantes. Posteriormente, } \\
\text { nova versão foi criada, a partir da compilação das } \\
\text { anteriores, e reconvertida para o inglês por um } \\
\text { profissional de saúde e um falante do português, } \\
\text { que tinha o inglês como língua nativa. As } \\
\text { retrotraduções foram reunidas em um documento } \\
\text { único, que foi enviado para o autor que } \\
\text { desenvolveu o questionário original. } 0 \\
\text { questionário foi aplicado em } 39 \text { pacientes } \\
\text { submetidos à laringectomia total, com, pelo } \\
\text { menos, um ano de pós-operatório. }\end{array}$ & Beaton et al. (2000) \\
\hline $\begin{array}{l}\text { Equivalência cultural } \\
\text { da versão brasileira do } \\
\text { Vocal Fatigue Index - } \\
\text { VFI }\end{array}$ & $\begin{array}{l}\text { Zambon et al. } \\
(2017)\end{array}$ & $\begin{array}{l}\text { Vocal Fatigue Index } \\
- \text { VFI }\end{array}$ & $\begin{array}{l}\text { O VFI foi traduzido para o português brasileiro por } \\
\text { dois fonoaudiólogos brasileiros e bilíngues } \\
\text { (Tradutor } 1-\mathrm{T} 1 \text { e Tradutor } 2-\mathrm{T} 2 \text { ), que } \\
\text { realizaram a tradução conceitual. As traduções } \\
\text { foram analisadas e comparadas por um comitê } \\
\text { formado por cinco fonoaudiólogos especialistas } \\
\text { em voz e com proficiência na língua inglesa. As } \\
\text { diferenças encontradas foram discutidas e, } \\
\text { quando necessário, modificações foram } \\
\text { realizadas, chegando-se a uma versão traduzida } \\
\text { final (versão em português - VP). A versão final } \\
\text { traduzida do protocolo foi retrotraduzida por um } \\
\text { terceiro fonoaudiólogo brasileiro bilíngue, que não } \\
\text { participou das etapas anteriores. A versão } \\
\text { retrotraduzida foi comparada à versão inglês } \\
\text { original do protocolo, chegando-se à versão em } \\
\text { português com equivalência semântica e do } \\
\text { idioma. }\end{array}$ & $\begin{array}{l}\text { Não é mencionado na pesquisa } \\
\text { autores referentes à metodologia } \\
\text { utilizada no processo tradutório. }\end{array}$ \\
\hline
\end{tabular}


continuação

\begin{tabular}{|c|c|c|c|c|}
\hline $\begin{array}{lrr}\text { Planilha } & \text { de } & \text { triagem } \\
\text { acústica da } & \text { sala } & \text { de } \\
\text { aula: tradução } & \text { e } \\
\text { adaptação } & \text { cultural } \\
\text { para o } & \text { Português } \\
\text { Brasileiro } & & \\
\end{array}$ & $\begin{array}{lll}\begin{array}{l}\text { Cruz } \\
(2017)\end{array} & \text { et } & \text { al. }\end{array}$ & $\begin{array}{l}\text { Classroom } \\
\text { Acoustical } \\
\text { Screening Survey } \\
\text { Worksheet }\end{array}$ & $\begin{array}{l}\text { O instrumento, em sua versão original, foi } \\
\text { distribuído para dois tradutores intérpretes de } \\
\text { inglês, fluentes no idioma, que não se conheciam } \\
\text { e não conheciam o instrumento. O grupo revisor } \\
\text { foi constituído por duas fonoaudiólogas } \\
\text { (brasileiras, fluentes em língua inglesa), que } \\
\text { analisaram os dois documentos resultantes e } \\
\text { reduziram as diferenças encontradas nas } \\
\text { traduções, adaptando o texto à cultura brasileira. } \\
\text { Para a revisão das equivalências gramatical e } \\
\text { idiomática, uma cópia do protocolo foi } \\
\text { encaminhada para outros dois tradutores. O } \\
\text { mesmo grupo revisor realizou nova avaliação das } \\
\text { duas versões resultantes, comparando-as com a } \\
\text { original em inglês. A adaptação transcultural } \\
\text { objetivou estabelecer a equivalência cultural entre } \\
\text { as versões inglesa e portuguesa do protocolo. }\end{array}$ & $\begin{array}{l}\text { Guillemin F, Bombardier C, Beaton } \\
\text { D. (1993) }\end{array}$ \\
\hline
\end{tabular}


Segundo os estudos encontrados nos portais em relação à área fonoaudiológica, pode-se inferir que a maioria utiliza o guia de tradução e adaptação sugerido por Guillemin, Bombardier e Beaton (1993). Outros utilizam, também, as etapas sugeridas pelo comitê Scientific Advisory Commitee of the Medical Outcomes Trust. O gráfico abaixo ilustra a quantidade de autores e seus respectivos usos nos estudos.

Gráfico 2 Autores mencionados no processo tradutório.

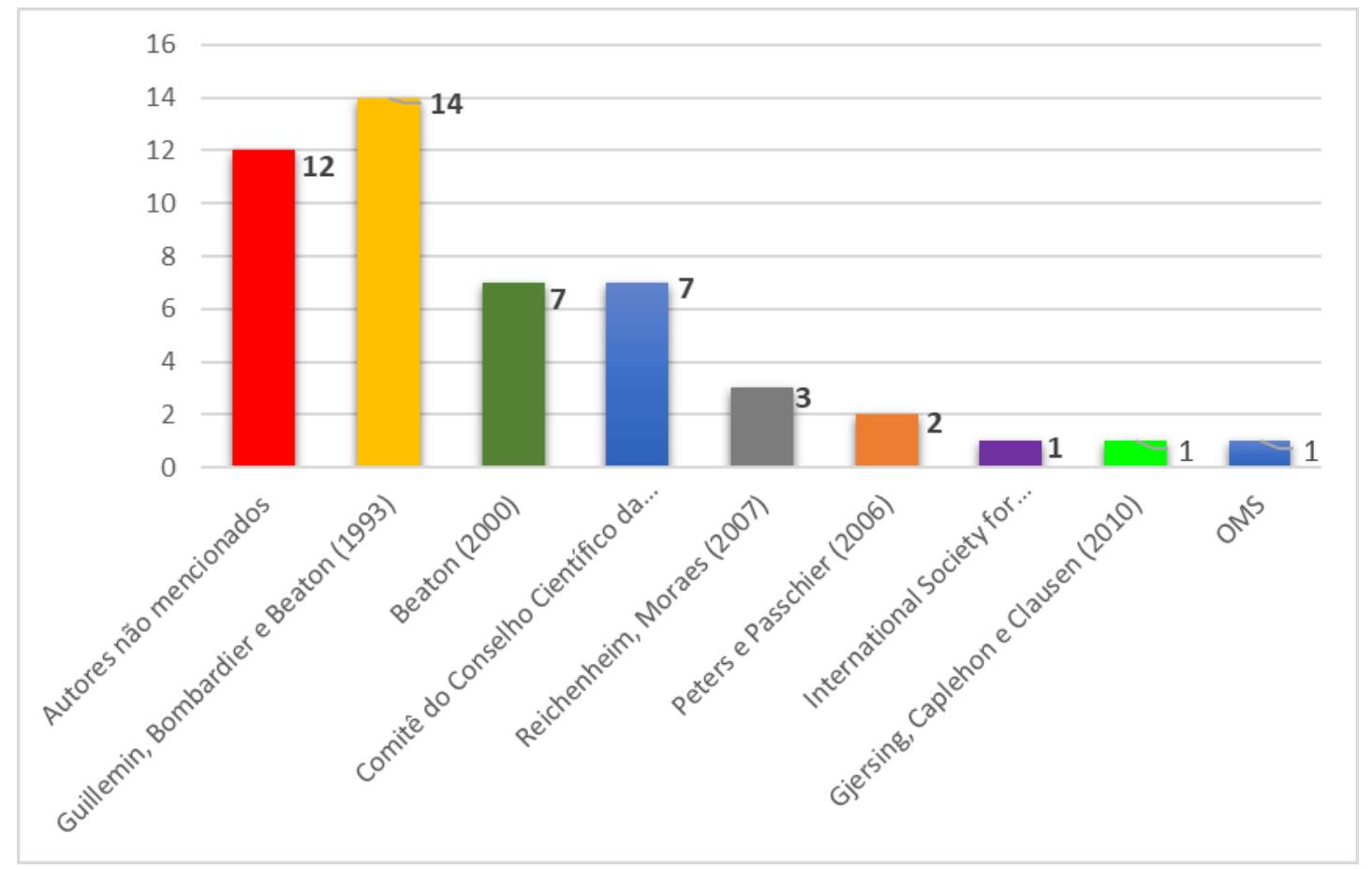

Fonte: Elaborado pela autora (2017)

Entretanto, ao analisar a tradução e adaptação na área da Fonoaudiologia, segundo Harkness e Schoua-Glusberg (1998), ainda não existem guias ou parâmetros suficientes para a realização da tradução e adaptação de instrumentos/ questionários. Outro fator apontado pelos pesquisadores, é a necessidade de o tradutor possuir conhecimento específico e adequado de acordo com o material que traduzirá, como protocolos, e esse apontamento também está presente no campo dos estudos de tradução. 


\subsection{Metodologias de Tradução}

\subsubsection{Brislin $(1970,1986)$}

A etapa da retrotradução foi incorporada ao processo tradutório na área da saúde pelo pesquisador Brislin $(1970,1986)$, que foi um dos pioneiros na elaboração de um modelo de tradução para instrumentos de pesquisa, numa perspectiva transcultural. Inserido a esse modelo, as considerações delineadas quanto à inserção ou modificação de novos itens nos instrumentos significa a necessidade do tradutor/ pesquisador em adaptar o instrumento dentro da contextualização em que este será aplicado.

Dessa forma, Brislin (1970) afirma que o método da retrotradução é eficaz para a verificação de equívocos cometidos durante o processo tradutório. Vale ressaltar que o processo tradutório, de acordo com Brislin (1970), deve ser composto de três tradutores, conhecedores da língua em que o instrumento será traduzido e para a análise geral da retrotradução.

Brislin (1986) delineia apontamentos a serem considerados pelos tradutores, os quais ele nomeia como regras:

1. Utilizar sentenças curtas e simples com menos de 16 palavras;

2. Empregar a voz passiva ao invés da ativa;

3. Repetir substantivos ao invés de utilizar pronomes;

4. Evitar metáforas e coloquialismos;

5. Evitar o subjuntivo e usar, por exemplo, as formas verbais "poderia", "gostaria", "deveria";

6. Acrescentar sentenças para dar contexto a ideias principais. Rescrever sentenças-chave para dar redundância.

7. Evitar advérbios e preposições como "onde" ou "quando" (por exemplo, frequente, além de, acima).

8. Evitar pronomes possessivos, quando possível.

9. Usar termos específicos mais do que termos generalizados (por exemplo, o animal específico, tal como vacas, frangos, porcos, ao invés do termo geral "animais domésticos");

10. Evitar palavras que indicam incerteza em relação a acontecimentos ou coisas (por exemplo, provavelmente e frequentemente);

11. Usar palavras familiares aos tradutores;

12. Evitar sentenças com dois verbos diferentes se os verbos sugerirem ações diferentes. (BRISLIN, 1986, p. 144-149, tradução minha).

De acordo com o supracitado, o tradutor deve considerar esses aspectos para o processo tradutório e da retrotradução. Para tal processo, o tradutor deve ter um conhecimento amplo da língua original, possuir um amplo vocabulário que o possibilitará encontrar prontamente um equivalente para termos não-familiares, e de produzir itens na língua de chegada que sejam compreensíveis e que correspondam 
ao projeto (instrumento) (BRISLIN, 1986, p. 143). Dessa forma, ainda segundo o autor (1986), ao seguir esses passos, os tradutores irão:

1. Compreender o elemento na língua original;

2. Ter grande probabilidade em encontrar um equivalente linguístico disponível na língua traduzida; dessa forma, eles não terão que utilizar termos distorcidos ou desconhecidos;

3. Ser capaz de produzir elementos na língua-alvo compreensíveis por vivências dos indivíduos que responderam ao questionário. (BRISLIN, 1986, p. 143 , tradução minha).

É relevante mencionar que Brislin $(1970,1986)$ entende por tradutor ${ }^{1}$ qualquer indivíduo que possui conhecimento na área da língua a ser traduzido o texto. Esse aspecto torna-se evidente quando Brislin (1970) afirma que o pesquisador de determinado assunto pode encontrar erros ao comparar o original com a tradução e que esse pesquisador pode desenvolver habilidades para detectar esses possíveis erros, realizando, dessa forma, a retrotradução. Dessa forma, Brislin $(1970,1986)$ delineou as seguintes etapas para o processo tradutório em que realça a importância da retrotradução para verificação de possíveis erros cometidos durante a tradução.

Figura 2 Método de tradução de Brislin et al.

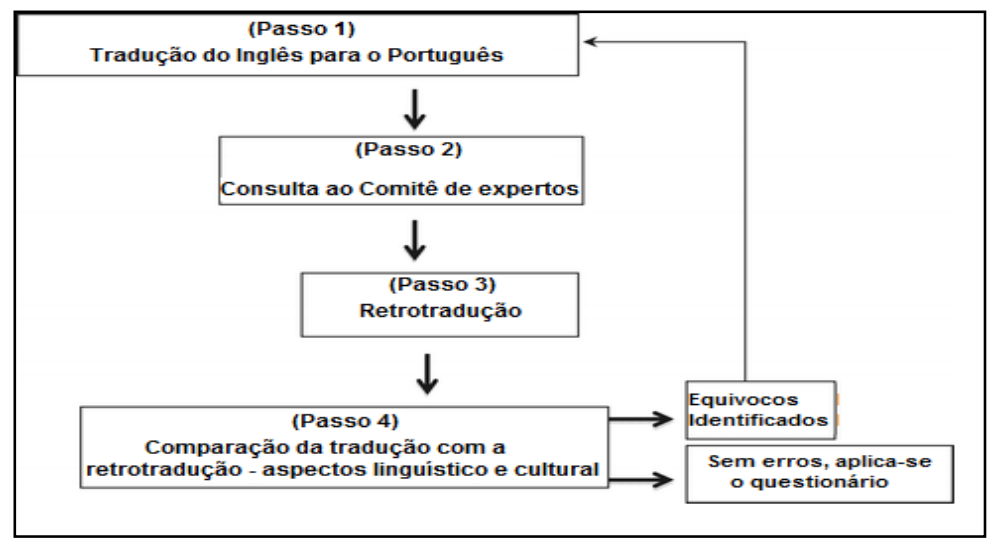

Fonte: Brislin et. al. (1973; 1986, adaptado).

A terceira etapa do processo tradutório (retrotradução) também pode ser representada pela figura abaixo:

\footnotetext{
${ }^{1}$ A palavra tradutor, mencionada não só nos estudos de Brislin $(1970,1986)$ como em outros, não corresponde efetivamente ao profissional graduado em tradução, uma vez que em seus estudos consta que as primeiras traduções podem ser realizadas por pessoas bilíngues ou professores de inglês.
} 
Figura 3 Processo da retrotradução de Brislin et al.

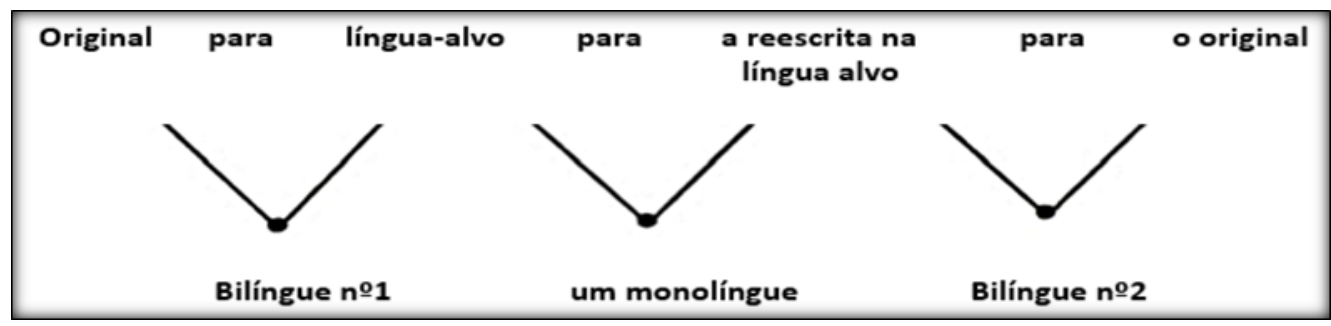

Fonte: Brislin (1986, p. 162).

Portanto, nota-se que Brislin (1986) além da etapa de retrotradução, propõe duas traduções distintas como forma de comparação na identificação de possíveis erros cometidos.

\subsubsection{IQOLA Project $(1998,2011)$}

Os apontamentos realizados pelo projeto de avaliação da qualidade de vida (International Quality of Life Assessment Project - IQOLA, 2011) tiveram como objetivo validar traduções de protocolos para uso em procedimentos clínicos internacionais e outros estudos relacionados à saúde, abarcando, nos últimos anos, desde 1991, 60 países.

Para tal, foram elaborados três passos a serem seguidos quanto à tradução: 1) traduzir de acordo com os procedimentos padronizados; 2) realizar o teste psicométrico e 3) série de estudos para avaliar a validade. A padronização mencionada no documento (BULLINGER et al., 1998) refere-se ao procedimento descrito a seguir (FIGURA 4) presente no Standardized Short Form Health Survey (WARE; SHERHOURNE, 1992), que contém 36 perguntas relacionadas à avaliação da qualidade de vida (SF-36).

De acordo com o IQOLA (BULLINGER et al., 1998), existem três etapas para a conclusão do processo de tradução: 1- tradução rigorosa e avaliação dos procedimentos para garantir uma equivalência conceitual e aprovação do entrevistado; 2- testes psicométricos formais das premissas subjacentes à pontuação do item e à construção de escalas de variadas e 3- avaliação da validade das escalas e o acúmulo dos dados normativos e outras diretrizes de interpretação (tradução nossa). É importante mencionar que os critérios adotados pela IQOLA 
(1998, 2011) também sugerem a retrotradução, sendo esta realizada por dois profissionais distintos.

Figura 4 Etapas do processo de tradução e adaptação de protocolos de testes psicométricos de acordo com a atualização do Projeto do IQOLA.

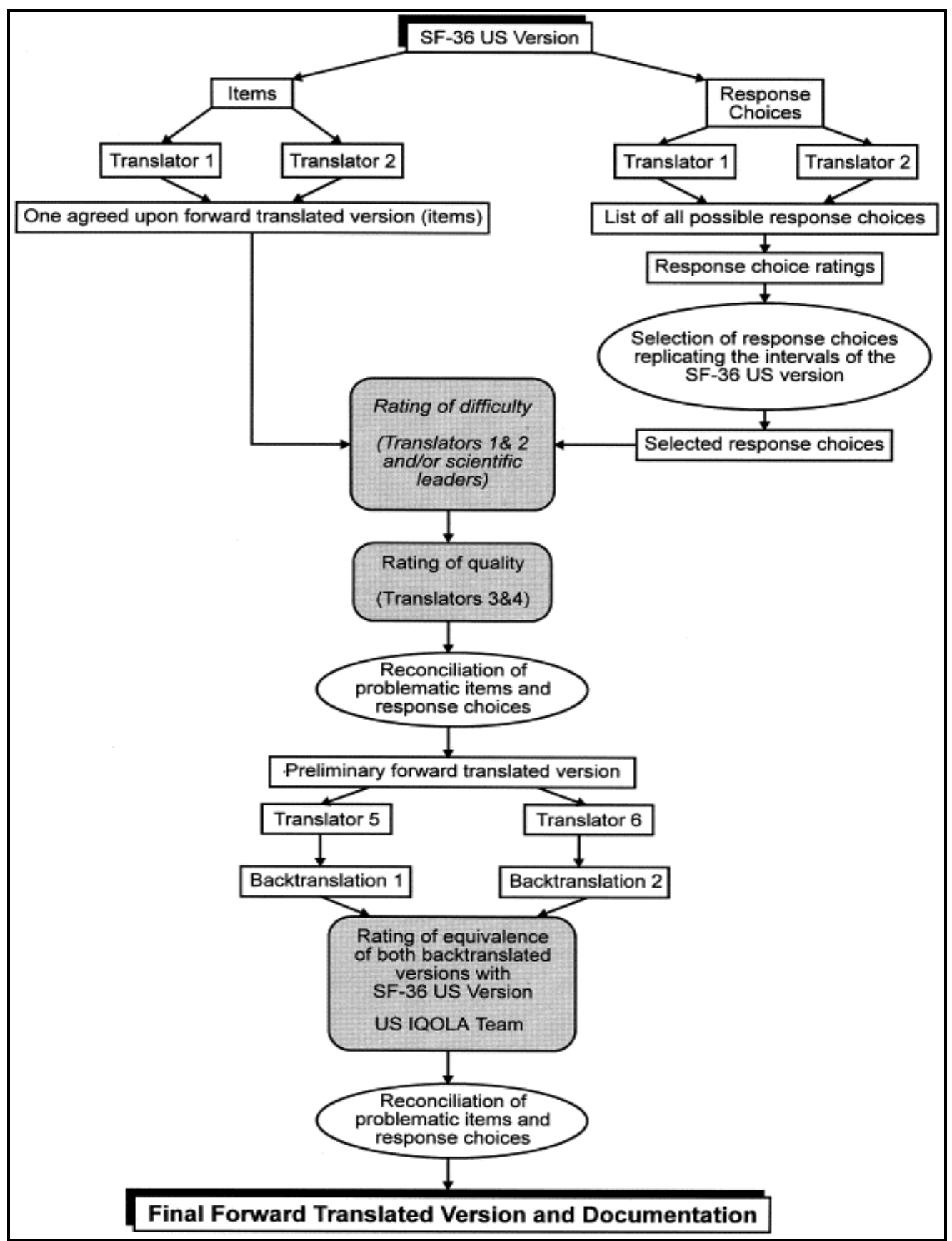

Fonte: Bullinger et al. (1998, p. 915).

O protocolo SF-36 foi traduzido a partir do original em inglês norteamericano e foi produzido entre 1991 e 1992. 


\subsubsection{Guillemin et al. (1993) e Beaton et al. (2002)}

Por meio da tradução e da adaptação cultural, os pesquisadores Guillemin, Bombardier e Beaton (1993) e Beaton et al. (2002) sugeriram em seus estudos um "guia" para esse processo, incluindo, também, a etapa da retrotradução (FIGURA 5).

Figura 5 Processo da tradução, adaptação, retrotradução, análise dos perito e pré-teste criados por Beaton et al.

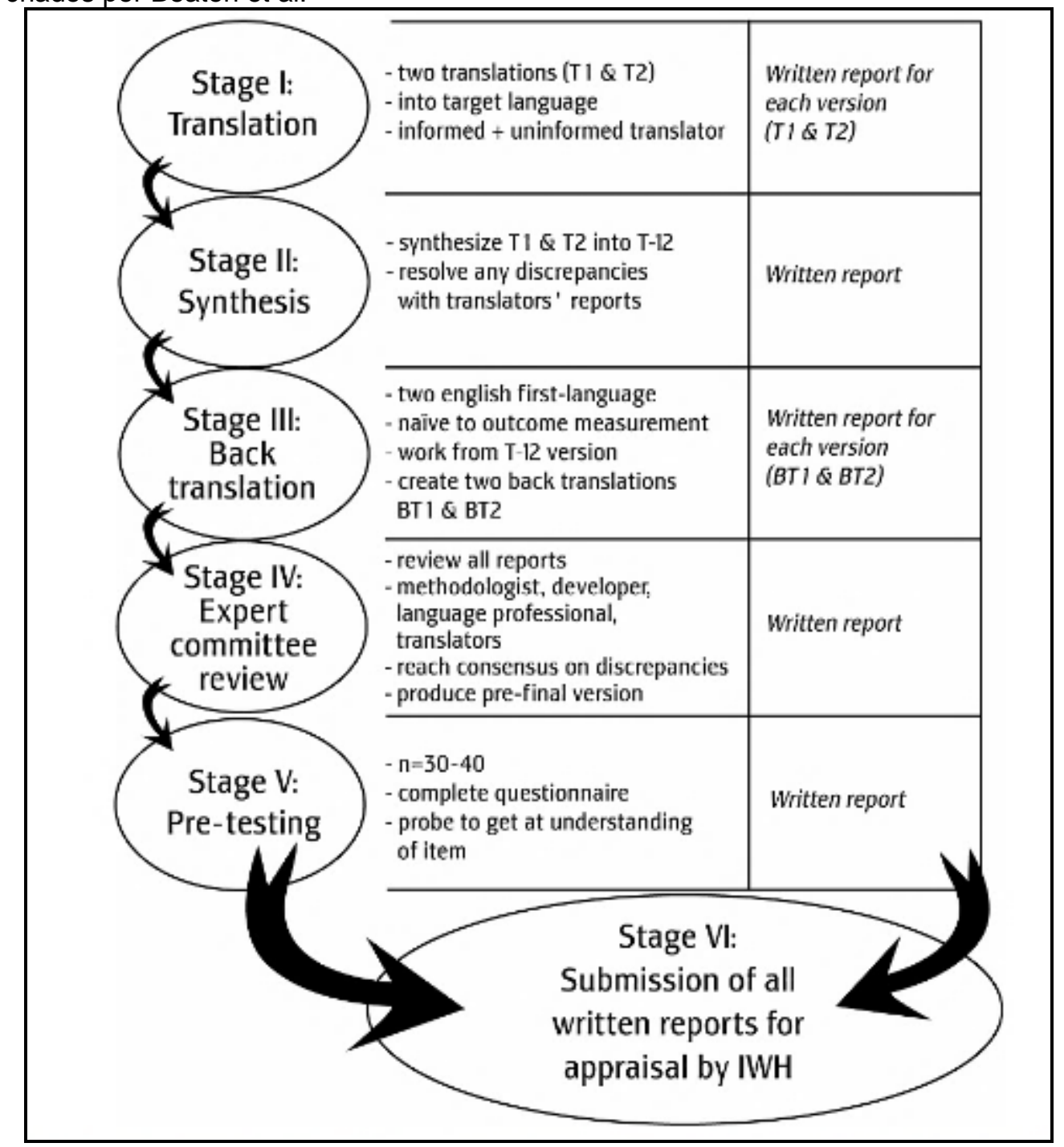

Fonte: Beaton et al. (2002, p. 06). (adaptado)

Dessa forma, nos dizeres de Beaton et al. (2002), a adaptação transcultural de um questionário auto-administrável para uso em outros países, culturas e/ou idiomas necessita de uma metodologia a ser seguida para alcançar equivalências na tradução e adaptação entre o instrumento original e o idioma a ser 
traduzido. Assim, os autores recomendam cinco passos para a adaptação cultural de protocolos na área da saúde: (1) traduções independentes; (2) síntese das traduções; (3) retrotraduções da síntese; (4) reunião de um comitê de peritos; (5) pré-teste.

Segundo Guillemin et al. (1993), o processo de tradução abarca não só uma simples tradução, ou seja, da língua estrangeira para a língua de chegada, mas também o processo de transculturação, ao considerar que cada protocolo traduzido deve ser contextualizado à realidade do paciente e do país do qual o procedimento avaliativo ocorre.

Neste sentido, Beaton et. al. (2007) ao elaborarem o estudo direcionado à tradução transcultural de instrumentos avaliativos na área da saúde discutem que esse processo deve ter como caráter inicial um levantamento sobre o que é esperado na perspectiva da tradução, no que se refere às mudanças (linguísticas e culturais) e o que a adaptação exigirá a partir dessa tradução. Para verificar possíveis equívocos encontrados, Guillemim et al. (1993) e Beaton et al. (2002) sugerem a etapa da retrotradução, sendo esta realizada por profissionais distintos aos tradutores da versão original.

Ainda de acordo com Beaton et al. (2002) existem quatro etapas dentro do processo de tradução e adaptação cultural elaborado pelos pesquisadores:

Equivalência Semântica: aspectos relacionados ao significado, à gramática;

Equivalência idiomática: relacionado à aspectos linguísticos (morfológicos, léxicos, sintáticos, expressões).

Equivalência experimental: aspectos culturais relacionados ao cotidiano ou a palavras que não possuem tradução na língua de chegada.

Equivalência conceitual: aspectos relacionados à equivalência de significado da palavra/ expressão.

Para a validade do documento, Beaton et al. (2002) afirma que: "o novo instrumento deve reter tanto as características do nível do item como correlações de item em escala e consistência interna; e as características de nível de confiabilidade, validade de elaboração e receptividade (tradução minha). ${ }^{2}$

2 The new instrument should retain both the item-level characteristics such as item-to-scale correlations and internal consistency; and the score-level characteristics of reliability, construct validity, and responsiveness. (BEATON et al., 2000, p. 3.189) 


\subsubsection{Wang, Lee e Fetzer (2006)}

Nos estudos de Wang, Lee e Fetzer (2006) os autores propõem uma modificação na retrotradução como forma de potencializar a equivalência na tradução. Em sua pesquisa, os autores mencionam as etapas de Brislin (1986) e a importância do processo de retrotradução. Desse modo, Wang, Lee e Fetzer (2006) descrevem cinco etapas para a realização da tradução transcultural do instrumento HSQ (WANG; LEE; FETZER, 2006). De acordo com a pesquisa, participaram do processo tradutores bilingues, falantes monolíngues e bilingues, participantes monolíngues e bilingues e peritos em linguagem.

Figura 6 Etapas do processo de tradução e adaptação elaborados por Wang, Lee e Fetzer (2006)

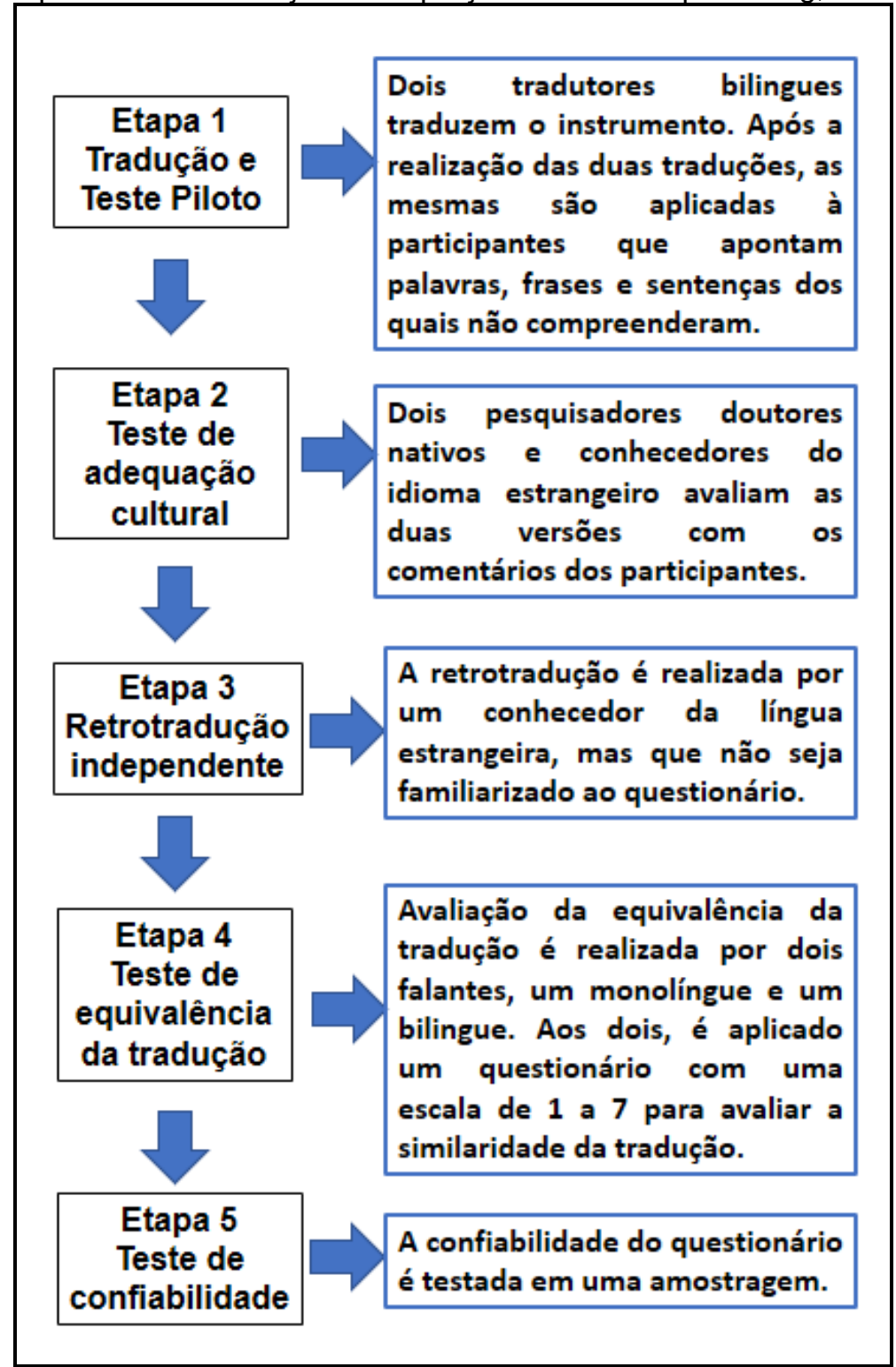

Fonte: Wang, Lee e Fetzer (2006, p. 313-318, adaptado). 
A proposta de Wang, Lee e Fetzer (2006) foi aplicada em alguns estudos recentes que realizaram a tradução e a adaptação de questionários para 0 português brasileiro.

\subsubsection{ISPOR Project (2005)}

A International Society For Pharmacoeconomics and Outcomes Research (ISPOR) é um grupo na área da sáude que discute normas e padrões para a tradução e adaptação cultural de resultados informados pelos pacientes (PRO), ou seja, questionários aplicados a pacientes. De acordo com o ISPOR (WILD et al., 2005) participam dessa equipe 12 maiores grupos ${ }^{3}$ com normas disponíveis publicadas, atualmente, para tradução e adaptação cultural.

Cada membro do ISPOR é delegado a revisão de determinada etapa. Dessa forma, os resultados das normas são avaliados em uma reunião e, em seguida, elaborados uma nova descrição metodológica. Para a modificação das normas, é necessário que os grupos: realizem uma análise racional de cada etapa; descrevam os indivíduos envolvidos em cada uma e apresentem resultado de riscos assiciados ao incluir essa nova etapa nas normas (WILD et al., 2005).

Portanto, para o processo de tradução e adaptação cultural, o ISPOR indica as seguintes etapas:

- $\quad$ Preparação - trabalho inicial executado antes do início da tradução.;

- Tradução - Tradução do material original, também chamado de versão do instrumento para outra língua, frequentemente chamado de lingua de chegada;

- Conciliação - comparação e união de mais de uma tradução em apenas uma versão;

- Retrotradução - Nova tradução para a língua original do instrumento;

3 1. American Association of Orthopaedic Surgeons (AAOS); 2. Association of Test Publishers; 3. Grupo EORTC; 4. Grupo Euro QoL [EuroQoL, não-publicado]; 5. Evidence: Clinical and Pharmaceutical Research; 6. Grupo FACIT; 7. Grupo Health Outcomes (HOG); 8. Health Utilities Inc. (HUInc); 9. Grupo International Quality of Life Assessment (IQOLA); 10. Kidney Disease Quality of Life (KDQOL); 11. Medical Outcomes Trust (MOT); e 12. Organização Mundial de Saúde. 
- Revisão da retrotradução - comparação das duas versões da retrotradução e da versão resultante da concordância com o original para esclarecer e investigar discrepâncias, das quais são revisadas no processo para a resolução de erros;

- Harmonização - comparação entre as retrotraduções das versões das duas línguas (a tradução e a versão) para esclarecer as discrepancias entre o original e as derivadas traduções, tais como realizar uma abordagem consistente para os problemas de tradução;

- Relatório cognitivo - teste do instrumento em um grupo pequeno de pacientes ou de indivíduos quaisquer para testar outros vocabulários e checar a compreensão, interpretação e relevância cultural da tradução;

- Resultado da revisão do relatório cognitivo e finalização - comparação da interpretação dos pacientes e indivíduos sobre a tradução com a versão original para esclarecer e apurar as discrepâncias;

- Revisão - revisão final da tradução para elucidar e corrigir qualquer erro tipográfico, gramatical ou outros;

- Versão final - versão escrita ao final do processo e documentando o desenvolvimento de cada etapa da tradução. (WILD et al., 2005, p. 97, tradução minha)

Entretanto, durante a revisão de algumas normas, o grupo indicou quatro problemas encontrados: falta de consistência (no uso de terminologias e métodos); lacunas ou informações insuficientes na literatura sobre várias áreas de importância, incluindo harmonização e revisão final; poucas informações sobre o porquê de cada etapa ser seguida, não identificando o risco de omissão de partes importantes no processo de tradução; e, maior ênfase em ideais teóricos para tradução e adaptação transcultural do que é realmente factível na prática (WILD et al., 2005, tradução minha).

\subsubsection{Ozolins (2009)}

Sob a perspectiva de Ozolins (2009), a retrotradução é uma etapa muito conhecida dentro das organizações médicas, lideradas pela OMS, como forma de controlar o acesso a realização precisa e transferências de significados comparáveis entre as línguas em estudos internacionais de saúde. (grifos 
meus). Entretanto, essa "etapa" nunca foi objeto de estudo por parte de teóricos da tradução.

Ainda de acordo com Ozolins (2009), a retrotradução, quando utilizada como meio de estabelecer uma comunicação transparente entre tradutores e autores, pode ser uma ferramenta de voz aos tradutores. Em sua pesquisa, dessa forma, Ozolins (2009) afirma que o processo de comparação das traduções para resultar na retrotradução é válido quando os tradutores conversam entre si. Em sua pesquisa, também, Ozolins (2009) menciona que pesquisadores de um hospital em Melbourne (Austrália) desenvolveram um protocolo de avaliação em pacientes com artrite severa conhecido como MAPT (Multiattribute Arthritis Prioritisation Tool) e exigiram uma metodologia do processo tradutório que se encaixasse às normas estabelecidas pela Organização Europeia de Pesquisa e Tratamento do Câncer (EORTC). Dessa forma, foi delineada a seguinte metodologia ${ }^{4}$ :

- Instruções da equipe do MAPT sobre tradutores e revisores

- Única tradução

- Revisão independente da tradução

- Única retrotradução

- Comentários (por e-mail) da equipe do MAPT

- Discrepâncias entre o texto original em inglês e a retrotradução

- Comentários (por e-mail) do tradutor do original e do tradutor da retrotradução sobre os comentários da equipe do MAPT

- Teleconferência final entre a equipe do MAPT e os tradutores sobre algum item não resolvido, além da retrotradução, caso apresente problemas

- Documentação da qualificação dos tradutores e experiências

- Teste piloto pela equipe do MAPT (OZOLINS, 2009, p.4, tradução minha)

Entretanto, apesar do exemplo desse estudo na Austrália, Ozolins (2009) acredita que a retrotradução foi bem-sucedida porque o método comparativo foi utilizado, enaltecendo, dessa forma, o trabalho dos tradutores e a comunicação dos mesmos. Outro aspecto relevante de apontar é o fato do protocolo já estar em língua inglesa e necessitar uma metodologia que se encaixasse no modelo internacional do EORTC para contemplar os itens que a Organização Mundial de Saúde requere.

Ainda de acordo com Ozolins (2009), a metodologia final não contemplou os aspectos que o EORTC exige e a retrotradução foi alvo de críticas por parte dos pesquisadores.

\footnotetext{
${ }^{4}$ Para maiores informações, acesse: < http://trans-int.org/index.php/transint/article/view/38>
} 


\subsubsection{Coulthard (2013)}

Os estudos de Coulthard (2013) foram um dos primeiros no Brasil a contestar a etapa da retrotradução no processo de tradução e adaptação cultural. De acordo com Coulthard, não existe o termo retrotradução nos estudos da tradução e esse vocábulo foi criado a partir de pesquisadores que pretendiam verificar erros cometidos em traduções de protocolos auto-administráveis; traduções essas realizadas por pessoas que apenas tinham conhecimento do idioma estrangeiro sem a formação acadêmica em tradução.

Sob essa perspectiva, Coulthard (2013) faz uma análise crítica sobre a retrotradução realizada no processo de tradução e adaptação cultural de protocolos relacionados à área da Saúde. De acordo com Coulthard (2013), o processo de retrotradução só é mencionado e realizado pelos pesquisadores ao traduzir um protocolo pois quem faz, geralmente, a comparação do original e da tradução, pode qualquer pessoa que tenha conhecimento da língua original do texto.

Portanto, essas etapas são mencionadas dentro do processo de tradução a adaptação e a retrotradução, uma vez que possuem o caráter de verificar as mudanças realizadas nesse processo e se elas estão de acordo com o propósito do protocolo. Por conseguinte, a sugestão de etapas no processo tradutório e, em especial à área da Saúde, proporcionará uma confiabilidade maior para a o produto final.

[...] Os altos requisitos exigidos para traduzir textos técnicos se sobressaem perante outros gêneros, o que faz com que esse tipo de tradução se configure como uma área de pesquisa independente. Além das qualificações exigidas para uma boa tradução, a tradução científica ainda precisa respeitar tanto a função referencial da língua quanto as convenções da linguagem técnica, exigência esta que não se realiza em outros tipos de tradução na medida em que diz respeito a um conhecimento preciso do mundo (VIEIRA, 2016, p. 135).

Dessa forma, em seu estudo, Coulthard (2013) propõe a contratação de, no mínimo, dois tradutores para realizar a tradução, ambos com experiência, como se trabalhassem em uma agência.

O método de Coulthard (2013) elimina a retrotradução, possibilitando a tradução e revisão em colaboração dos tradutores e sem a interferência da equipe detentora do protocolo. O método do autor (2013) está embasado tanto nos 
preceitos teóricos como na experiência profissional do mesmo, e foi testado pela agência Scientific Linguagem, de Porto Alegre.

De acordo com Coulthard (2013) foram contratados dois tradutores profissionais da agência para a empreitada do projeto. As tradutoras realizaram uma tradução inicial e conversavam entre si para a realização da tradução, por exemplo, para determinada terminologia. Dessa forma, os dois tradutores realizaram o produto final para o consenso final dos realizadores do protocolo.

Ao concluir sua pesquisa, Coulthard (2013) prova que a retrotradução não serve como propósito que os pesquisadores estabelecem para a adaptação transcultural, muito em relação ao propósito de Ozolins (2009) sobre a retrotradução expressar o trabalho do tradutor. Ainda segundo Coulthard (2013, p.290), A conclusão inevitável é que a retrotradução deve ser eliminada do processo de adaptação transcultural sempre que tradutores especialistas peritos estão disponíveis para traduzir. (tradução minha)" 5 .

\subsection{0 protocolo}

O Measure of Processes of Care (MPOC): A Means to Assess FamilyCentred Behaviours of Health Care Providers é um protocolo criado pelos pesquisadores King, Rosenbaum e King (1995), do Centro de Pesquisa sobre Deficiências na Infância - CanChild - do Instituto de Ciências Aplicadas à Saúde da Universidade de McMaster, situada em Hamilton, província de Ontário (Canadá), como forma de avaliar os serviços prestados pelo Centro de Terapia na perspectiva das famílias de pacientes com deficiência.

A elaboração e estruturação do protocolo foram possíveis por meio de estudos prévios realizados que buscavam a compreensão da percepção dos pais sobre os serviços e cuidados oferecidos à família pelos profissionais do centro de reabilitação. Primeiramente, existia um projeto piloto composto por 101 questões e, para evidenciar a importância desse estudo, o MPOC passou por três fases de estruturação para, ao final, ser composto por 56 questões.

Para os autores que desenvolveram o instrumento de avaliação, o primeiro importante passo é a identificação dos domínios a serem alcançados com as

5 "[...] the inevitable conclusion is that back-translation should be eliminated from cross-cultural adaptation processes whenever specialist expert translators are available to translate [...]". (COULTHARD, 2013, p.290) 
respostas dos participantes sobre os serviços recebidos pelas pessoas no hospital ou centro de terapia por meio da percepção dos pais dos participantes (crianças em tratamento). A partir disso, é possível identificar o quanto esses serviços de cuidados com a saúde auxiliam no tratamento de reabilitação desse paciente.

Cunningham e Rosenbaum (2014) realizaram um levantamento sobre estudos que abordaram o MPOC para avaliar os serviços recebidos pelos indivíduos (geralmente crianças) sob a perspectiva dos pais e/ ou responsáveis. Dentre os 107 estudos analisados em diferentes línguas nas quais o protocolo foi validado (inglês, alemão, finlandês e chinês), os autores destacam que a maioria buscou dados referentes aos serviços prestados para crianças entre a idade pré-escolar e fundamental (de 03 a 10 anos). Entretanto, os autores relatam também que o questionário foi aplicado fora a dessa margem de idade, ou seja, foram encontrados estudos realizados com crianças de dois meses até adultos com 26 anos. Os países que compõem o quadro de tradução e validação analisadas pelos pesquisadores (CUNNINGHAM \& ROSENBAUM, 2014) do MPOC são: Canadá, Holanda, Austrália, Inglaterra, Suécia, Finlândia, Singapura, Islândia, Noruega e África do Sul.

Ainda relacionado ao estudo realizado por Cunningham e Rosembaum (2014), pode-se destacar que aspectos culturais e linguísticos foram determinantes para a tradução e validação do MPOC, dentro da perspectiva da avaliação dos sons psicométricos em cada estudo analisado.

Em outro estudo, realizado por Joachim (2014), na West University em Ontário (Canadá), menciona-se a importância da aplicação desse questionário (mesmo em sua forma reduzida - MPOC-20) em pacientes com epilepsia. Dessa forma, Joachim (2014) conclui que o tratamento baseado nos cuidados centrados na família deveria ser refletido nas experiências do tratamento dessas crianças e de suas famílias.

Nessa perspectiva, Knox e Menzies (2005) realizaram uma pesquisa para investigar as percepções das famílias de crianças quanto ao tratamento fornecido pelos profissionais na habilitação/ reabilitação recebidos no Centro Bobath, na Escócia, no período de 12 meses. O MPOC-56 foi o instrumento apropriado, segundo a autora, para avaliar o propósito do estudo. Nesse estudo, por meio da aplicação do instrumento MPOC-56, foi possível a autora concluir que os serviços oferecidos pelo centro eram satisfatórios, com a equipe trabalhando sempre em conjunto com a família. 
Já em um estudo realizado por Rahi et. al. (2005), o instrumento MPOC-56 foi utilizado como forma de avaliar os serviços de saúdes prestados a partir da percepção dos familiares em pacientes com deficiência visual. De acordo com o estudo, as famílias que possuíam menos recursos financeiros ou por questões raciais recebiam menos atenção e cuidados dos serviços oferecidos do que as famílias que possuíam melhores condições financeiras ou que não pertenciam a uma minoridade étnica. Dessa forma, pertinente ao estudo, foi possível que os autores concluíssem que essa forma de avaliação da equipe profissional do centro analisado prejudicou significativamente no atendimento e no tratamento dos pacientes com deficiência visual.

Em estudos realizados por O'Neil et al. (2001), o MPOC-56 foi utilizado como forma de verificar a percepção da família quanto aos serviços e comportamentos dos terapeutas para com seus filhos, tais como se os serviços prestados condiziam com as idades das crianças e se a intervenção precoce e 0 tratamento foram válidos. Ao final, os pesquisadores concluíram que a participação das mães e, consequentemente, suas percepções, foram maiores que de outros membros da família (no caso, os pais), em virtude da idade dos pacientes (desde sete meses aos dois anos de idade, $61 \%$ ).

Dessa forma, os estudos realizados sob a vertente da aplicação do MPOC56 demonstram que esse instrumento permite não só verificar a satisfação dos pais quanto ao tratamento recebido por seus filhos, como também o próprio centro de reabilitação avaliar suas condutas para com seus pacientes, com a finalidade de obter resultados satisfatórios.

\subsubsection{Descrição do instrumento}

O The Measure of Processes of Care - MPOC (KING, ROSENBAUM, KING, 1995) avalia o grau de satisfação da família quanto ao programa de habilitação intensiva. De acordo com os escores estabelecidos pelo protocolo, são observadas as seguintes opções em uma escala de 0 como não aplicável, 1 para quando a situação nunca ocorre e 7 para quando estão muito satisfeitos. Dessa forma, a composição dos escores é definida como: 7-= Muito satisfeito; 6-= Satisfeito; 5-= 
Muitas vezes; 4-= Bastantes vezes; $3-=$ Às vezes; 2-= Poucas vezes; $1-=$ Raramente; 1-= Nunca e 0-= Não aplicável.

O objetivo do MPOC-56 é mensurar a experiência dos pais de crianças com deficiência, com ênfase na auditiva, pois a tradução desse instrumento tem como escopo a validação para auxiliar os profissionais da área da Fonoaudiologia e, em especial, para avaliar as percepções quanto aos cuidados e tratamento recebido pelo profissional e pelo Centro de Terapia (equipe).

Portanto, esse instrumento é aplicado por um profissional diferente daquele que realizou e/ou coordenou o processo terapêutico da criança. Os pais e/ ou responsáveis são orientados a indicar o quanto um evento ou uma situação ocorreu durante o processo terapêutico do Centro avaliado. Os comentários dos pais e/ ou responsáveis são avaliados em cinco domínios: envolvimento dos pais, acessibilidade e disponibilidade dos serviços, continuidade e consistência dos cuidados, coordenação dos cuidados e abordagem centrada na família.

Dessa forma, as questões estão agrupadas por quem são esses contatos, como descrito abaixo:

1. PESSOAS: Se refere àqueles indivíduos que trabalham diretamente com você ou seu filho. Estes podem incluir fonoaudiólogos, psicólogos, terapeutas, assistentes sociais, médicos, professores, etc.

2. INSTITUIÇÃO: Se refere a toda equipe do centro, envolvida diretamente ou não com seu filho. Além das pessoas do centro de tratamento, esta podem incluir a equipe de apoio que trabalha no escritório, serviços gerais, departamento administrativo, etc.

\subsubsection{Estudos realizados com MPOC-56}

O instrumento de avaliação MPOC-56 foi utilizado em sua versão completa em diversos países, após a realização da adaptação de acordo com o idioma falado pela população/ participante das pesquisas. No total, foram encontrados dez estudos que contemplassem a eficácia do instrumento criado por King, Rosenbaum e King (1995), para a compreensão da perspectiva da família em 
relação ao atendimento tanto de profissionais como do centro de terapia durante o tratamento do paciente. Esses estudos estão sintetizados na Tabela 1. 
Quadro 2 Estudos realizados com o instrumento MPOC-56

\begin{tabular}{|c|c|c|c|c|c|}
\hline Título & Autores/ano & Instituição/País & Área aplicada & Métodos & Resultados \\
\hline
\end{tabular}

continua 
continuação

\begin{tabular}{|c|c|c|c|c|c|}
\hline $\begin{array}{l}\text { Using the Measure of } \\
\text { Processes of Care to } \\
\text { Assess Parents' Views } \\
\text { of a Paediatric } \\
\text { Therapy Service }\end{array}$ & $\begin{array}{ll}\text { KNOX, } & \text { V.; } \\
\text { MENZIES, } & \text { S. } \\
(2005) & \end{array}$ & $\begin{array}{l}\text { Bobath Scotland, } \\
\text { Glasgow, Escócia }\end{array}$ & $\begin{array}{l}\text { Medicina } \\
\text { Crianças com } \\
\text { paralisia infantil }\end{array}$ & 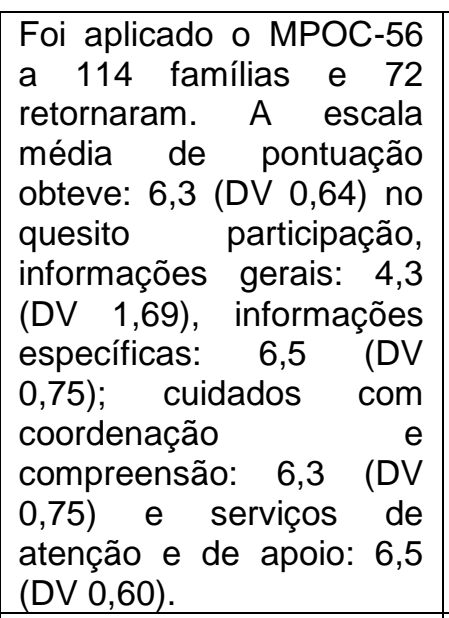 & $\begin{array}{l}\text { Os resultados encontrados } \\
\text { mostraram que as famílias } \\
\text { estavam satisfeitas com o } \\
\text { tratamento recebido pelo } \\
\text { hospital. O MPOC provou ser } \\
\text { uma ferramenta apropriada para } \\
\text { investigar as percepções dos } \\
\text { serviços do centro pediátrico. }\end{array}$ \\
\hline $\begin{array}{l}\text { Parent and Health } \\
\text { Care Professional } \\
\text { Perspectives on } \\
\text { Family-centered Care } \\
\text { for Children with } \\
\text { Special Health Care } \\
\text { Needs: Are We on the } \\
\text { Same Page? }\end{array}$ & $\begin{array}{l}\text { BELLIN et al. } \\
(2011)\end{array}$ & Estados Unidos & Pediatria & $\begin{array}{l}\text { Estudo transversal } \\
\text { observacional por meio } \\
\text { da aplicação do MPOC- } \\
56 \text { administrado em uma } \\
\text { amostra representativa de } \\
92 \text { pais de crianças com } \\
\text { cuidados especiais de } \\
\text { saúde. Para análise, um } \\
\text { modelo de variância misto } \\
\text { conduziu os estudos para } \\
\text { diferentes grupos com } \\
\text { escores do MPOC-56. }\end{array}$ & $\begin{array}{l}\text { Os resultados indicaram que o } \\
\text { MPOC-56 é eficaz para avaliar a } \\
\text { comunicação entre o centro de } \\
\text { tratamento e a família; } \\
\text { entretanto, os profissionais } \\
\text { devem aperfeiçoar } \\
\text { atendimento. }\end{array}$ \\
\hline $\begin{array}{lr}\text { Information } & \text { and } \\
\text { professional support: } \\
\text { key factors in the } \\
\text { provision of family- } \\
\text { centred } \\
\text { childhood intervention } \\
\text { services. }\end{array}$ & $\begin{array}{l}\text { FORDHAM; } \\
\text { GIBSON; } \\
\text { BOWES (2012) }\end{array}$ & $\begin{array}{l}\text { Nova Gales do Sul, } \\
\text { Austrália. }\end{array}$ & Pediatria & $\begin{array}{l}\text { Estudo transversal } \\
\text { observacional por meio } \\
\text { da aplicação do MPOC- } \\
56 \text { e da Escala de } \\
\text { Empoderamento Familiar } \\
\text { (FES) a } 130 \text { famílias de } \\
\text { um centro de tratamento } \\
\text { em Nova Gales do Sul, } \\
\text { Austrália. }\end{array}$ & $\begin{array}{l}\text { Os resultados demonstraram } \\
\text { que houve correlações positivas } \\
\text { entre o MPOC-56 e o FES em } \\
\text { todas as cinco sub-escalas do } \\
\text { MPOC-56 e duas para o FES } \\
\text { (afirmando a satisfação das } \\
\text { famílias). }\end{array}$ \\
\hline
\end{tabular}




\begin{tabular}{|c|c|c|c|c|c|}
\hline $\begin{array}{l}\text { Parents' perceptions of } \\
\text { the services provided } \\
\text { to children with } \\
\text { cerebral palsy in the } \\
\text { transition } \\
\text { preschool from } \\
\text { rehabilitation to } \\
\text { school-based services. }\end{array}$ & $\begin{array}{l}\begin{array}{l}\text { ALSEM } \\
(2016)\end{array} \\
\text { et al. }\end{array}$ & $\begin{array}{l}\text { Organização para o } \\
\text { desenvolvimento de } \\
\text { Pesquisas em Saúde da } \\
\text { Holanda, Holanda. }\end{array}$ & Pediatria & $\begin{array}{l}\text { Estudo transversal } \\
\text { observacional com pais de } \\
59 \text { crianças com paralisia } \\
\text { cerebral com idade de } 2,5 \\
\text { a 4,5 anos) por meio da } \\
\text { aplicação do MPOC-56. Os } \\
\text { testes de Friedman foram } \\
\text { usados para descrever as } \\
\text { mudanças nas percepções } \\
\text { dos pais ao longo do } \\
\text { tempo. Os testes U de } \\
\text { Mann -Whitney foram } \\
\text { utilizados para descrever } \\
\text { as diferenças de } \\
\text { percepções dos pais entre } \\
\text { a escola regular e escola } \\
\text { especial ou creche. }\end{array}$ & $\begin{array}{l}\text { As percepções de serviços pré- } \\
\text { escolares dos pais mantiveram-se } \\
\text { estáveis entre as idades de } 2,5 \text { e } \\
3,5 \text { anos, com um declínio após a } \\
\text { transição em quatro dos cinco } \\
\text { domínios do MPOC (P<0,05). O } \\
\text { domínio fornecendo informações } \\
\text { gerais foi marcado como menor } \\
\text { (mediana no início do estudo } 3,56 \text {, } \\
\text { IQR } 2,39 \text { ) em comparação com os } \\
\text { outros quatro domínios MPOC, } \\
\text { mas manteve-se estável ao longo } \\
\text { do tempo. Não houve diferenças } \\
\text { nos cursos de percepções dos pais } \\
\text { para o tipo de escola. }\end{array}$ \\
\hline $\begin{array}{l}\text { Measurement of } \\
\text { family-centred care: } \\
\text { translation, adaptation } \\
\text { and validation of the } \\
\text { Measure of Processes } \\
\text { of Care (MPOC-56 } \\
\text { and -20) for use in } \\
\text { Japan. }\end{array}$ & $\begin{array}{l}\text { HIMURO; } \\
\text { KOZUKA; MORI } \\
\text { (2013) }\end{array}$ & Saporo, Japão. & Medicina & $\begin{array}{l}\text { Estudo prospectivo } \\
\text { transversal para a versão } \\
\text { japonesa do MPOC-56 com } \\
\text { a aplicação em } 261 \\
\text { famílias de crianças que } \\
\text { recebem serviços de } \\
\text { reabilitação. }\end{array}$ & $\begin{array}{l}\text { O MPOC-56 mostrou adequada } \\
\text { consistência interna com om o } \\
\text { Coeficiente Alfa de Cronbach, } \\
\text { variando entre } 0,76 \text { e } 0,94 \text {. A } \\
\text { validade de construto foi } \\
\text { examinada com a análise } \\
\text { conformativa de cada estrutura } \\
\text { escala. As correlações entre os } \\
\text { escores da escala MPOC e } \\
\text { pontuações perguntas de } \\
\text { satisfação foram positivas. }\end{array}$ \\
\hline $\begin{array}{l}\text { Family caregivers' } \\
\text { perceptions of } \\
\text { hospital-based allied } \\
\text { health services post- } \\
\text { stroke: use of the } \\
\text { Measure of Processes } \\
\text { of Care to investigate } \\
\text { processes of care. }\end{array}$ & $\begin{array}{l}\text { LOVAT et al. } \\
(2010)\end{array}$ & $\begin{array}{l}\text { Faculdade de Ciências } \\
\text { de Sidney, Austrália. }\end{array}$ & Medicina & $\begin{array}{l}\text { A primeira etapa envolveu } \\
\text { a adaptação do MPOC-56 } \\
\text { projetado para medir as } \\
\text { percepções de atendimento } \\
\text { profissional e suporte em } \\
\text { cinco dimensões de } \\
\text { cuidados. A confiabilidade } \\
\text { do questionário adaptado } \\
\text { foi avaliado e estatísticas } \\
\text { foram computadas. }\end{array}$ & $\begin{array}{l}\text { A confiabilidade do MPOC } \\
\text { adaptado foi considerada alta, com } \\
\text { boa consistência interna dos itens } \\
\text { dentro de cada sub-escala e as } \\
\text { pontuações médias indicaram que } \\
\text { os responsáveis pelas crianças } \\
\text { relataram mais fatos negativos do } \\
\text { que positivos em relação aos } \\
\text { serviços recebidos pelo centro de } \\
\text { tratamento. }\end{array}$ \\
\hline
\end{tabular}


continuação

\begin{tabular}{|c|c|c|c|c|c|}
\hline $\begin{array}{l}\text { Evaluation of the } \\
\text { processes of family- } \\
\text { centred care for young } \\
\text { children } \\
\text { intellectual disability in } \\
\text { Western Australia. }\end{array}$ & $\begin{array}{l}\text { WILKINS et al. } \\
(2010)\end{array}$ & $\begin{array}{l}\text { Estado da Austrália } \\
\text { Ocidental, Austrália }\end{array}$ & $\begin{array}{l}\text { Psicologia, } \\
\text { Fisioterapia e } \\
\text { Fonoaudiologia }\end{array}$ & $\begin{array}{l}\text { O estudo incluiu crianças } \\
\text { de } 0-6 \text { anos matriculadas } \\
\text { na Comissão de Serviços } \\
\text { de Deficiência do Estado } \\
\text { da Austrália Ocidental. Os } \\
\text { pais preencheram o } \\
\text { MPOC-56). Os escores } \\
\text { médios para os domínios } \\
\text { das cinco áreas do MPOC } \\
\text { foram comparados usando } \\
\text { a análise de variância } \\
\text { ANOVA contra as variáveis } \\
\text { independentes do grupo } \\
\text { filho idade, grupo de } \\
\text { diagnóstico da criança, tipo } \\
\text { de serviço e frequência, } \\
\text { local de residência, família } \\
\text { e variáveis demográficas. }\end{array}$ & $\begin{array}{l}\text { Das } 292 \text { famílias escolhidas, } \\
165 \text { (59\%) devolveram o } \\
\text { questionário preenchido. Mais } \\
\text { de } 50 \% \text { das crianças tiveram } \\
\text { contato pelo menos uma vez por } \\
\text { mês, com os terapeutas } \\
\text { ocupacionais, fonoaudiólogos e } \\
\text { fisioterapeutas; já menos de } \\
20 \% \text { das crianças tiveram } \\
\text { contato pelo menos anual com } \\
\text { qualquer psicólogo ou serviços } \\
\text { odontológicos. As famílias } \\
\text { demonstraram satisfação para o } \\
\text { item "cuidado respeitoso e } \\
\text { solidário" e insatisfeitos para } \\
\text { "fornecendo informações } \\
\text { gerais". As análises individuais } \\
\text { de cada família indicaram menor } \\
\text { satisfação com a " informação e } \\
\text { atenção integral". As maiores } \\
\text { médias foram associadas ao } \\
\text { contato mais frequente com } \\
\text { terapia. }\end{array}$ \\
\hline
\end{tabular}

continua 
continuação

\begin{tabular}{|c|c|c|c|c|c|}
\hline $\begin{array}{l}\text { Evaluation of the } \\
\text { processes of family- } \\
\text { centred care for young } \\
\text { children with } \\
\text { intellectual disability in } \\
\text { Western Australia. }\end{array}$ & $\begin{array}{l}\text { WILKINS et al. } \\
(2010)\end{array}$ & $\begin{array}{l}\text { Estado da Austrália } \\
\text { Ocidental, Austrália }\end{array}$ & $\begin{array}{l}\text { Psicologia, } \\
\text { Fisioterapia e } \\
\text { Fonoaudiologia }\end{array}$ & $\begin{array}{l}\text { O estudo incluiu crianças } \\
\text { de } 0-6 \text { anos matriculadas } \\
\text { na Comissão de Serviços } \\
\text { de Deficiência do Estado } \\
\text { da Austrália Ocidental. Os } \\
\text { pais preencheram o } \\
\text { MPOC-56). Os escores } \\
\text { médios para os domínios } \\
\text { das cinco áreas do MPOC } \\
\text { foram comparados usando } \\
\text { a análise de variância } \\
\text { ANOVA contra as variáveis } \\
\text { independentes do grupo } \\
\text { filho idade, grupo de } \\
\text { diagnóstico da criança, tipo } \\
\text { de serviço e frequência, } \\
\text { local de residência, família } \\
\text { e variáveis demográficas. }\end{array}$ & $\begin{array}{l}\text { Das } 292 \text { famílias escolhidas, } \\
165 \text { (59\%) devolveram o } \\
\text { questionário preenchido. Mais } \\
\text { de } 50 \% \text { das crianças tiveram } \\
\text { contato pelo menos uma vez por } \\
\text { mês, com os terapeutas } \\
\text { ocupacionais, fonoaudiólogos e } \\
\text { fisioterapeutas; já menos de } \\
20 \% \text { das crianças tiveram } \\
\text { contato pelo menos anual com } \\
\text { qualquer psicólogo ou serviços } \\
\text { odontológicos. As famílias } \\
\text { demonstraram satisfação para o } \\
\text { item "cuidado respeitoso e } \\
\text { solidário" e insatisfeitos para } \\
\text { "fornecendo informações } \\
\text { gerais". As análises individuais } \\
\text { de cada família indicaram menor } \\
\text { satisfação com a " informação e } \\
\text { atenção integral". As maiores } \\
\text { médias foram associadas ao } \\
\text { contato mais frequente com } \\
\text { terapia. }\end{array}$ \\
\hline
\end{tabular}


Cunninghan e Rosenbaum (2014) realizaram um estudo, por meio de uma revisão sistemática nos principais portais relacionados à saúde (PubMed e Web of Science) e foram identificados 107 artigos nos quais o MPOC foi citado. Ainda, de acordo com os autores (2014), o instrumento foi utilizado em 11 países e traduzidos para 14 línguas. Os estudos realizados com a versão na íntegra do documento totalizaram 18 e, dessa forma, em concomitância com o objetivo desta pesquisa, os estudos elencados na Tabela 1 correspondem à versão primária do instrumento.

A partir da elaboração do MPOC, foram criados outros instrumentos com número reduzido de questões, modificados de acordo com o contexto de cada pesquisa e país. $O$ instrumento pode ser encontrado nas seguintes formas: MPOCSP (Measure of Processes of Care - Service Providers), MPOC-20 (redução para 20 questões), MPOC-A (versão para adultos), MPOC-28 (versão para o usuário) e 0 MPOC-8 (ISA) (versão para a África do Sul).

Portanto, é possível notar nos estudos realizados (QUADRO 2) que a maioria dos estudos sobre tradução e adaptação de protocolos sugere dez etapas para tal processo (GUILLEMIN et al., 1993), outros seguem cinco (BEATON et al., 2000) e outros aplicam a metodologia de Brislin $(1970,1986)$.

O gráfico abaixo demonstra, em valores, as porcentagens dos estudos que mencionam ou não a metodologia do processo tradutório empregada.

Gráfico 3 Descrição da metodologia do processo tradutório nos artigos

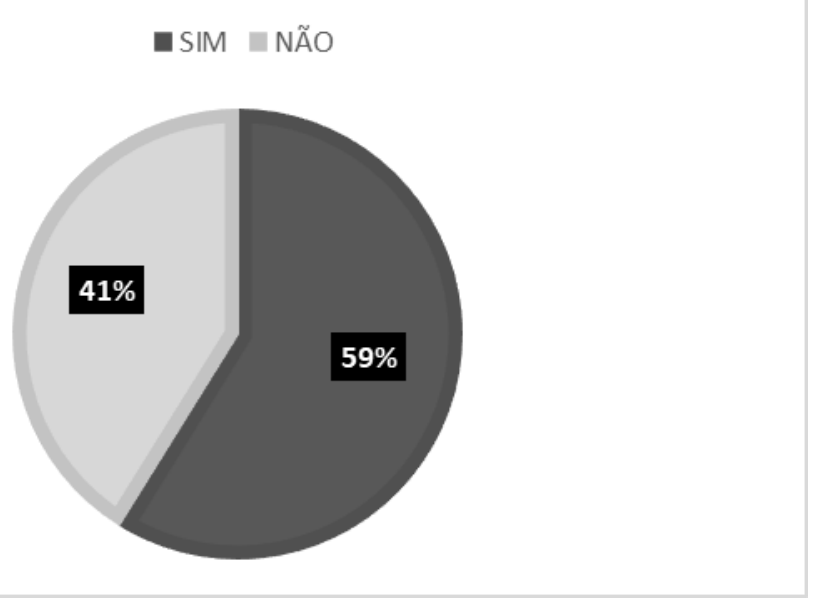

Fonte: Elaborado pela autora (2017).

Desse modo, na maioria dos estudos realizados, nota-se a retrotradução como um dos principais meios para a diminuição e verificação de possíveis 
equívocos durante a tradução. Entretanto, de acordo com o Ozolins (2009), a retrotradução não é alvo de pesquisas dentro do campo da tradução e esse aspecto reflete a escassa bibliografia relacionada à processos de tradução na área da saúde, em específico, sobre instrumentos e protocolos.

\subsection{Medição da inteligibilidade}

A inteligibilidade de um texto reflete os conhecimentos e usos da língua materna que potencializam habilidades para os usos dessa mesma língua. Isso significa que saber compreender e interpretar consiste na decifração de uma atividade (CHARAUDEUAU, 2009, p. 114). Portanto, de acordo com Nelson (2011), não é concebível a discussão do conceito de inteligibilidade sem mencionar os indivíduos participantes do contexto comunicacional.

Figura 7 Esquema elementar da comunicação para a análise do discurso

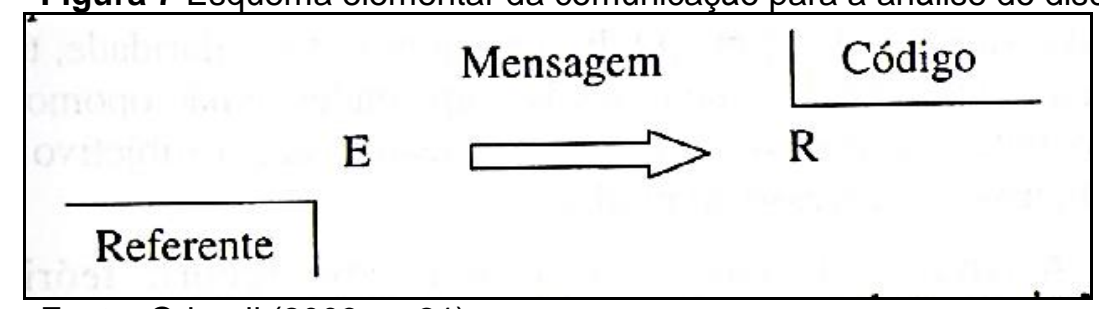

Fonte: Orlandi (2003, p. 21)

Dessa forma, a primeira parte da verificação quanto à inteligibilidade ocorreu durante o brainstorming (PASQUALI, 1998), com a participação dos peritos da área da fonoaudiologia (e dominadores do discurso científico nesta área) sobre a inteligibilidade de vocábulos e da semântica textual.

Ao considerar o aspecto da inteligibilidade, a autora Orlandi (2003) defende que esta promove sentido à língua, ou seja, é por meio da inteligibilidade que o sentido do texto é construído pelo receptor e que, após essa interpretação, este irá compreender o texto ao decodificar o enunciado.

Leffa (1996, p. 89) também menciona o termo inteligibilidade como: "qualidade de um texto quanto a sua capacidade de proporcionar facilidade de compreensão". Ao analisar compreensão do texto por essa perspectiva, é possível identificar que, por meio da inteligibilidade, o texto torna-se de fácil de ler e de ser compreendido pelo receptor. É importante ressaltar que o vocábulo inteligibilidade surgiu do inglês readability que significa habilidade de leitura (BARBOSA; NUNES, 
2007), ou seja, o indivíduo desenvolve a capacidade de leitura por meio de textos compreensíveis. A inteligibilidade pode ser, portanto, utilizada de três formas, a saber:

1) para indicar legibilidade de escritos manuais ou tipográficos; 2) para indicar facilidade de leitura conforme o valor/interesse ou agradabilidade de leitura; 3) para indicar o fácil entendimento ou compreensão devido ao estilo de escrever. (BARBOSA; NUNES, 2007, p.23)

Outro autor que aborda a questão da inteligibilidade é Coscarelli (2003), que explica a frequência como sendo um aspecto determinante para o processar da palavra dentro de uma sentença ou texto. Coscarelli (2003) menciona que, na língua portuguesa, existem algumas construções que tornam a inteligibilidade mais difícil em um texto. Segundo o autor, "palavras muito comuns na língua com as quais se depara a todo momento, mesmo fugindo ao padrão silábico comum, não causam muitos problemas de leitura" (COSCARELLI, 2003, p. 3).

Portanto, os procedimentos técnicos que foram aplicados à tradução tiveram como objetivo promover a inteligibilidade textual, com a perspectiva de deixar o material de fácil compreensão, promovendo as reformulações necessárias. 
3 Proposição 



\section{PROPOSIÇÃO}

O presente estudo tem por objetivo realizar a tradução para a Língua Portuguesa do questionário The Measure of Processes of Care (MPOC-56), e verificar a inteligibilidade da tradução considerando a retirada da etapa da retrotradução. 

Material e Métodos 



\section{MATERIAL E MÉTODOS}

\subsection{Tipo de Estudo}

Esta pesquisa é caracterizada como metodológica em virtude das investigações dos métodos de obtenção, organização e análise dos dados para a tradução de um instrumento. Nessa pesquisa, o escopo é a adaptação para a língua portuguesa de maneira precisa e utilizável e que possa ser empregado por outros pesquisadores (POLIT; BECK; HUNGLER, 1995) na área da Saúde. Como esta pesquisa é uma nota metodológica que não envolveu coleta em seres humanos, não foi necessário submeter o estudo à apreciação de comitê de ética

A tradução do protocolo The Measure of Process of Care (ANEXO 1) foi realizada em virtude da falta de um instrumento em Língua Portuguesa falada no Brasil que avaliasse por completo as expectativas dos pais referentes ao tratamento e ao centro de terapia à qual seu (sua) filho (a) estivesse submetido. Esse instrumento foi validado em sua versão reduzida (MPOC-SP) para a Língua Portuguesa em Portugal (MAIA, 2012), contendo 20 questões. Portanto, almejou-se a tradução desse instrumento em sua versão completa, com 56 questões (MPOC56), sem perda da essência ou de significado no idioma original (língua inglesa).

Dessa forma, foram considerados os procedimentos de tradução, tais como: tradução, avaliação tradução por um comitê de expertos, versão final. Para compor o procedimento de tradução, a pesquisadora optou por analisar os questionários (original e a tradução), considerando a etapa do brainstorming, fator esse crucial para a compreensão e leitura do texto sob a perspectiva de coesão, coerência, semântica e sintática.

\subsection{Metodologia do processo tradutório}

A tradução é considerada, de acordo com alguns teóricos como Holmes (2000), como uma sequência de escolhas que o tradutor faz para chegar ao seu destino e considerando que algumas dessas escolhas possibilitam diferentes opções na constituição de um texto. Para este estudo, foram abordadas as metodologias sugeridas por Pasquali (1998), por meio do brainstorming e por Coulthard (2013) que sugere a retirada da etapa da retrotradução no processo tradutório. 
Dessa forma, "o tradutor, mediador da comunicação interlinguística e intercultural, deve procurar uma equivalência que torne o texto de chegada "funcional" na cultura receptora" (CHANUT, 2012, p. 49). Ainda de acordo com a autora, o tradutor não pode ignorar as armadilhas que a língua lhe impõe, e a equivalência deve ser compreendida, no ato tradutório, como equivalência a um elemento "equivalente no plano do discurso e não no plano do sistema da língua". (CHANUT, 2012, p. 49).

\subsubsection{Passo 1: Tradução do inglês para o português}

O processo de tradução consiste na escolha de profissionais com conhecimento linguístico tanto em língua inglesa quanto da língua portuguesa, para a procura do máximo de equivalência sem que ocorra distorção do produto final. Neste estudo, a tradução foi realizada por um tradutor, sendo a própria pesquisadora, com graduação em Tradução.

\subsubsection{Passo 2: Consulta ao comitê de peritos}

A tradução realizada no Passo 1 foi direcionada a dois fonoaudiólogos, fluentes em língua inglesa, que avaliaram, individualmente, a equivalência conceitual e cultural da tradução, considerando o público alvo envolvido. Em seguida, o pesquisador realizou a comparação das considerações dos dois especialistas para a elaboração da versão síntese, resultante das considerações realizadas pelos peritos da área e dos quais foram analisadas as divergências e possíveis equívocos.

\subsubsection{Passo 3: Comparação entre o original e a tradução}

A versão síntese foi realizada pelo próprio pesquisador-tradutor, a fim de que a versão traduzida estivesse equivalente à versão original, demonstrando a transculturação realizada no processo tradutório e reafirmando o conceito de Coulthard (2013) e Grunwald e Goldfarb (2006) sobre a importância do tradutor profissional para a realização da análise da adaptação transcultural do instrumento. 


\subsection{Medição da inteligibilidade dos textos}

Portanto, a análise da inteligibilidade deste questionário foi realizada a partir da etapa seguinte, isto é, durante o brainstorming, do qual os participantes discutiram os melhores léxicos e coerência textual com a finalidade de promover um questionário inteligível e, em seguida, a análise comparativa sob a perspectiva de Barbosa (2004).

\subsubsection{Brainstorming: avaliação da tradução}

A técnica do brainstorming consiste na reunião de pessoas que utilizam seus pensamentos e sugestões como forma de chegar a um denominador comum a respeito de determinado projeto. Como o próprio nome diz, brainstorming significa tempestade de ideias e, reunidas em um grupo de discussão, os indivíduos têm o objetivo de obter ideias inovadoras e criativa a respeito de algo (PASQUALI, 1998)

Para essa pesquisa, o brainstorming foi composto por quatro pessoas, a pesquisadora, a orientadora e duas especialistas na área da Fonoaudiologia, familiarizadas com serviço na área da saúde e fluentes em língua inglesa.

A discussão seguiu os seguintes passos: análise de item por item do questionário o original e o traduzido, considerando os apontamentos e sugestões das especialistas, mediante à um consenso por todos os participantes. Dessa forma, após a análise e a discussão do brainstorming, houve a adequação semântica e cultural na língua portuguesa do questionário (MPOC-56) e o questionário foi finalizado por meio das considerações do grupo.

Durante o brainstorming foram realizados apontamentos e análises quanto ao Centro de Tratamento e de seus serviços oferecidos onde o questionário será aplicado (na modalidade escrita). Dessa forma, também foram estabelecidas alterações para a versão em língua portuguesa adaptada de acordo com os parâmetros linguísticos e culturais. 


\subsubsection{Análise Comparativa}

A etapa anterior à elaboração da versão final consiste na realização da análise comparativa, a qual permite que o tradutor elucide as etapas do processo tradutório e elenque as transformações realizadas durante o processo. Para esta análise, foram utilizados os procedimentos técnicos de tradução segundo Barbosa (1990), apresentados no Quadro 3.

Quadro 3 Procedimentos técnicos de tradução elaborados por Barbosa (2004)

\begin{tabular}{|c|c|}
\hline 1) tradução palavra por palavra & $\begin{array}{l}\text { de uso restrito, devido à pouca frequência de } \\
\text { convergência total entre duas línguas; }\end{array}$ \\
\hline 2) tradução literal & $\begin{array}{l}\text { considera este procedimento o que mantém uma } \\
\text { "fidelidade semântica estrita"; }\end{array}$ \\
\hline 3) transposição & mudança de classe gramatical; \\
\hline 4) modulação & mudança de ponto vista; \\
\hline 5) equivalência & $\begin{array}{l}\text { substituição de um segmento do original por um na } \\
\text { tradução que lhe é funcionalmente equivalente. }\end{array}$ \\
\hline 6) omissão x explicitação & $\begin{array}{l}\text { primeiro se refere ao processo de omitir elementos do } \\
\text { texto original que sejam desnecessários ou repetitivos } \\
\text { na tradução. A explicitação é o processo inverso; }\end{array}$ \\
\hline 7) compensação & $\begin{array}{l}\text { deslocamento de um recurso estilístico na tradução } \\
\text { que tenha efeito equivalente ao original, mas que se } \\
\text { encontra em outra posição no texto; }\end{array}$ \\
\hline 8) reconstrução de períodos & $\begin{array}{l}\text { mudança na construção de períodos na tradução, } \\
\text { reagrupando-os ou dividindo-os; }\end{array}$ \\
\hline 9) melhorias & correção, na tradução, de erros do original; \\
\hline 10) transferência & $\begin{array}{l}\text { introdução de elemento da língua original na tradução. } \\
\text { Barbosa diferencia quatro tipos de transferência: } \\
\text { a) estrangeirismo: transcrição de um elemento que } \\
\text { seja desconhecido pelos falantes da língua da } \\
\text { tradução. Pode adaptar-se à morfologia e fonologia da } \\
\text { língua com sua consagração pelo uso; } \\
\text { b) estrangeirismo transliterado: incorporação de um } \\
\text { elemento da língua do texto original com substituição } \\
\text { da convenção gráfica; } \\
\text { c) estrangeirismo aclimatado: adaptação de um } \\
\text { estrangeirismo à língua da tradução; e } \\
\text { d) estrangeirismo + explicação: adição de informação } \\
\text { ao estrangeirismo para que os receptores da tradução } \\
\text { possam compreendê-lo. Pode ser através de notas do } \\
\text { tradutor ou de informação diluída no texto. }\end{array}$ \\
\hline 11) explicação & $\begin{array}{l}\text { substituição do estrangeirismo por uma explicação, } \\
\text { utilizada de acordo com a finalidade da tradução; }\end{array}$ \\
\hline 12) decalque & $\begin{array}{l}\text { tradução literal de sintagmas ou frases da língua } \\
\text { original para a língua de tradução; }\end{array}$ \\
\hline 13) adaptação & $\begin{array}{l}\text { recriação, na tradução, de uma situação do texto } \\
\text { original que não existe na língua da tradução. }\end{array}$ \\
\hline
\end{tabular}




\subsubsection{A elaboração da versão final}

Após a identificação da inteligibilidade do instrumento por meio da análise comparativa, a versão final do instrumento foi disponibilizada e, dentro da perspectiva desse estudo, tornou-se completamente compreensível e equivalente ao questionário original. 

5 Resultados 



\section{RESULTADOS}

As etapas para a tradução do MPOC-56 descritas acima forneceram os seguintes resultados sistematizados em formas de tabelas e gráficos para maior compreensão do leitor e para ilustrar a inteligibilidade dos textos, tanto no original (língua inglesa) quanto em sua versão para o Português Brasileiro.

Como a pesquisadora possui proficiência no idioma original do instrumento, isto é, a língua inglesa, a mesma realizou a tradução inicial. Dessa forma, a pesquisadora (tradutora) reuniu-se com o grupo de discussão (delineado na metodologia do brainstorming) para as considerações das especialistas na área de Fonoaudiologia e proficientes, também, em língua inglesa, para chegar-se a um consenso sobre a versão na língua portuguesa, respeitando os aspectos semânticos e culturais de cada idioma (inglês e português).

Em virtude do conhecimento da língua inglesa, da formação inicial da pesquisadora e, pela proficiência em língua inglesa do comitê de peritos (fator este de extrema importância), o debate foi estabelecido para analisar a equivalência funcional para a elaboração da versão final. Dessa forma, obteve-se a seguinte esquematização das etapas desde o original em inglês para a versão em português.

Figura 8 Processo do brainstorming para a versão final da tradução.

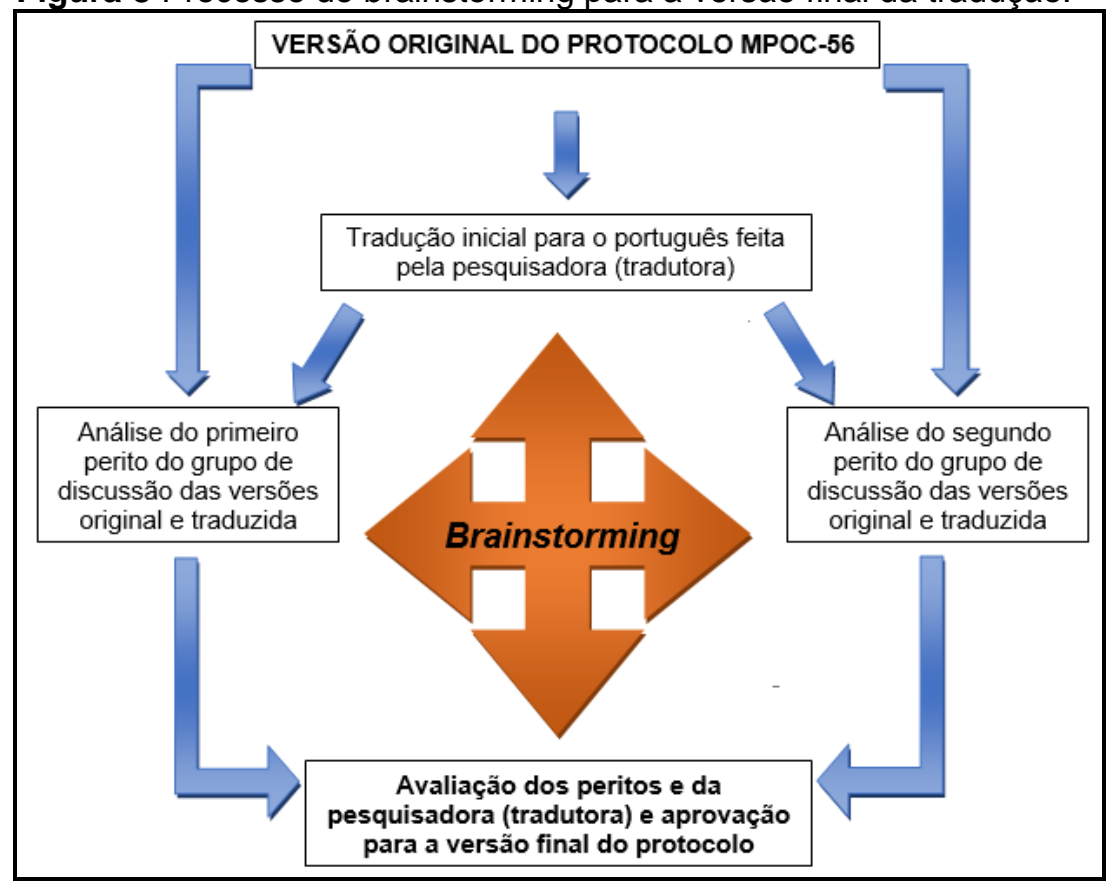

Fonte: Elaborado pela autora (2017) 
Após a realização das etapas delineadas acima, foi elaborado um quadro com as considerações realizadas pelo grupo de discussão, colocando em prática o desenvolvido pela técnica do brainstorming (PASQUALI, 1998).

\subsection{Considerações dos peritos e da pesquisadora}

O primeiro perito analisou, primeiramente, o texto informativo anterior ao questionário. Em seguida, foram realizadas as análises das questões e elaborada a Tabela 1 para melhor explicitar os resultados. 
Tabela 1 Resultados das considerações do primeiro perito.

\begin{tabular}{|c|c|c|}
\hline ORIGINAL & TRADUÇÃO & CONSIDERAÇÕES DO PERITO 1 \\
\hline
\end{tabular}


continuação




continuação

If you circled $n^{\circ} 4$ (Sometimes), it means that the people who give you questionnaires are clear in what they want you to some of the time, and some of the time the instructions are not clear.

If you circled $\mathrm{n}^{0} \mathbf{1}$ (Never), it means that although you have received questionnaires, the instructions are never clear.

If you circled $\mathrm{n}-0$ (Not Applicable), it means that you have never received a questionnaire and so you cannot answer the question. It does not apply to you.

We would like you to think about your experiences over the past year child's Centre. We are interested in your personal thoughts and would appreciate your completing this questionnaire on your own without discussing it with anyone.

For each question, please indicate how much the event or situation happens to you by circling one number (from 1 to 7) that you feel best fits your experience. When answering these questions, we would like to you to think about the Centre from which you first found about this study.

For easy reference, we have written the name of that Centre on this line:
Caso circule o número 4 (às vezes) significa que as pessoas que entregaram questionário a você forneceram instruções objetivas sobre o que queriam que você fizesse, mas não relacionado ao significado específico das perguntas.

Caso circule o número 1 (nunca), isso significa que, embora tenha recebido o questionário, as instruções não foram transmitidas adequadamente.

Caso circule o número 0 (não se aplica), isso significa que você nunca recebeu um questionário e, por conseguinte, não foi capaz de responder as questões, isto é, esse questionário não se aplica a você ou a sua realidade.

Gostaríamos que você pensasse sobre as experiências vividas nos últimos meses com seu filho no Centro. Estamos interessados em sua opinião para completar esse questionário que é de caráter confidencial.

Por favor, para cada questão indique a frequência da ocorrência, circule apenas um número (de 1 a 7) que melhor descreve a sua experiência. Enquanto responde a essas questões, gostaríamos que você pensasse também no Centro em que se realiza esse estudo.
Caso circule o número 4 (às vezes) significa que as pessoas que entregaram o questionário a você forneceram instruções claras sobre o que queriam que você fizesse em parte, mas para o resto as instruções não foram claras.

Caso circule o número 1 (nunca), isso significa que, embora tenha recebido o questionário, as instruções não foram claras.

Gostaríamos que você pensasse sobre as experiências vividas nos últimos meses com seu filho no Centro. Estamos interessados em sua opinião e gostaríamos que você completasse - questionário sozinho, sem discutir com outras pessoas.

Por favor, para cada questão indique a frequência com que a situação ou evento acontece com você, circule apenas um número (de 1 a 7) que melhor descreva a sua experiência. Enquanto responde a essas questões, gostaríamos que você pensasse no centro em que seu filho é acompanhado.

Para nossa referência, escreva o nome do centro nesta linha: 
continuação

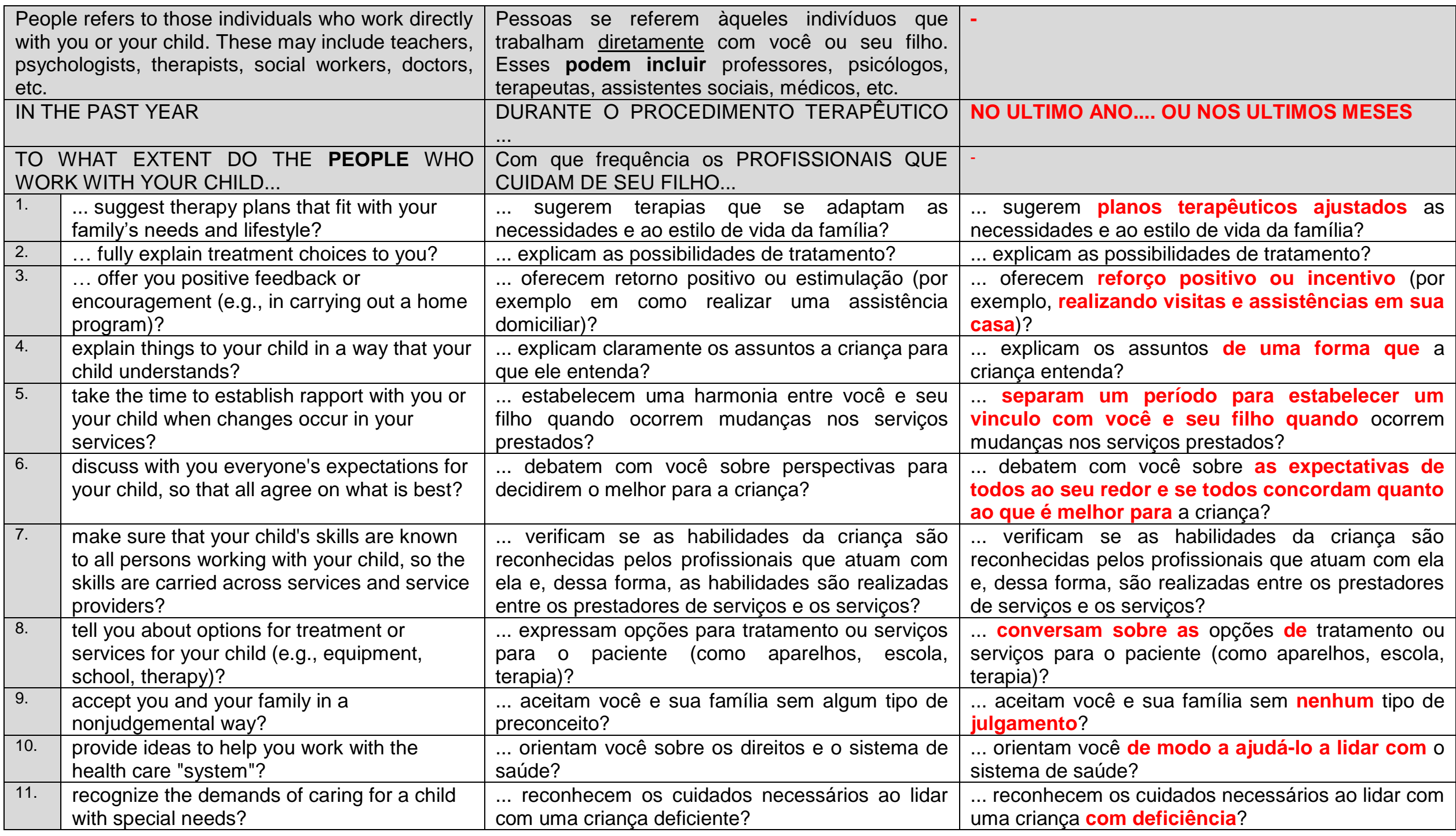


continuação

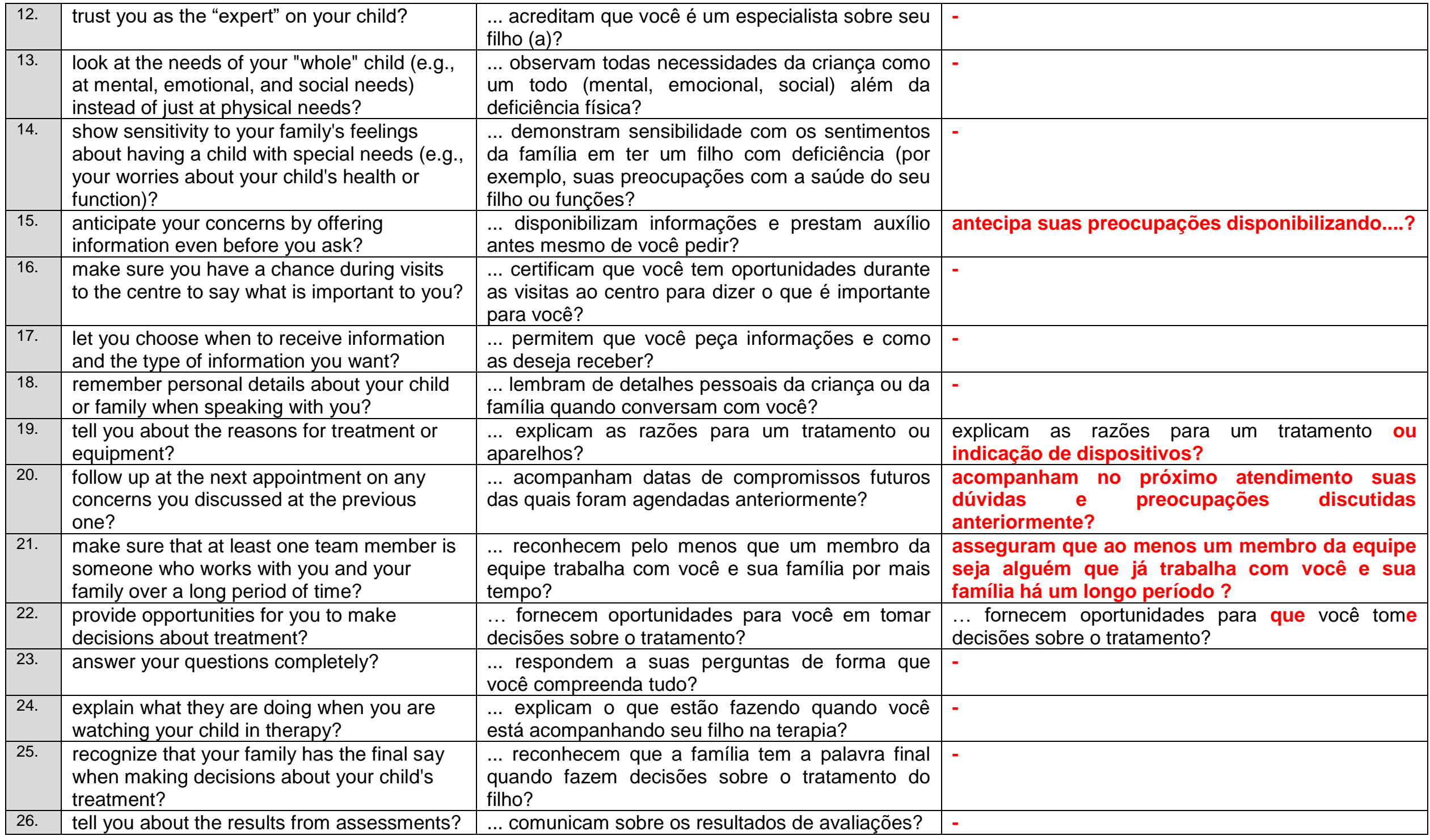


continuação

\begin{tabular}{|c|c|c|c|}
\hline 27. & $\begin{array}{l}\text { provide you with written information about } \\
\text { what your child is doing in therapy? }\end{array}$ & $\begin{array}{l}\text {... dão informações escritas sobre a o que seu } \\
\text { filho faz na terapia? }\end{array}$ & $\begin{array}{l}\text {... dão informações escritas quanto ao que seu filho } \\
\text { está realizando em terapia? / como está indo? }\end{array}$ \\
\hline 28. & $\begin{array}{l}\text { consult with you when discussing equipment } \\
\text { or services? }\end{array}$ & $\begin{array}{l}\text {... pedem sua opinião quando discutem sobre } \\
\text { aparelhos ou serviços? }\end{array}$ & $\begin{array}{l}\text {... pedem sua opinião quando discutem sobre os } \\
\text { dispositivos ou serviços? }\end{array}$ \\
\hline 29. & $\begin{array}{l}\text { provide a caring atmosphere rather than just } \\
\text { give you information? }\end{array}$ & $\begin{array}{l}\text {... proporcionam um ambiente acolhedor ao invés } \\
\text { de dar somente informações? }\end{array}$ & - \\
\hline 30. & $\begin{array}{l}\text { tell you details about your child's services, } \\
\text { such as the reasons for them, the type of } \\
\text { therapies and the length of time? }\end{array}$ & $\begin{array}{l}\text {... informam detalhes sobre serviços a seu filho, } \\
\text { tais como razões, tipo de terapias e duração? }\end{array}$ & $\begin{array}{l}\text {... informam detalhes quanto aos serviços que } \\
\text { atendem seu filho, como por exemplo, as razões } \\
\text { para indicá-los, os tipos de terapias e duração? }\end{array}$ \\
\hline 31. & $\begin{array}{l}\text { treat you as an individual rather than as a } \\
\text { "typical" parent of a child with a disability? }\end{array}$ & $\begin{array}{l}\text {... tratam você diferente por ser um responsável } \\
\text { "típico" de uma criança deficiente? }\end{array}$ & $\begin{array}{l}\text {... tratam você como uma pessoa ao invés de um } \\
\text { responsável por uma criança com deficiência? }\end{array}$ \\
\hline 32. & $\begin{array}{l}\text { develop both short-term and long-term goals } \\
\text { for your child? }\end{array}$ & $\begin{array}{l}\text {... estabelecem metas a curto e longo prazo para } \\
\text { seu filho? }\end{array}$ & - \\
\hline 33. & $\begin{array}{l}\text { treat you as an equal rather than just as the } \\
\text { parent of a patient (e.g.,by not referring to } \\
\text { you as "Mom" or "Dad")? }\end{array}$ & $\begin{array}{l}\text {... tratam você com igualdade sem chamar apenas } \\
\text { de responsável pelo paciente (por exemplo não se } \\
\text { refere a você como "pai" ou "mãe)"? }\end{array}$ & $\begin{array}{l}\text {... tratam você como uma pessoa igual sem se } \\
\text { referir a você apenas como responsável pelo } \\
\text { paciente (por exemplo não se refere a você como "pai" } \\
\text { ou "mãe", e sim pelo seu nome)? }\end{array}$ \\
\hline 34. & $\begin{array}{l}\text { plan together so they are all working in the } \\
\text { same direction? }\end{array}$ & $\begin{array}{l}\text {.. planejam o tratamento juntos para que } 0 \\
\text { mesmo objetivo seja trabalhado? }\end{array}$ & - \\
\hline 35. & $\begin{array}{l}\text { make sure you have opportunities to explain } \\
\text { what you think are important treatment } \\
\text { goals? }\end{array}$ & $\begin{array}{l}\text {... garantem a você oportunidades para que opine } \\
\text { sobre os objetivos do tratamento? }\end{array}$ & - \\
\hline 36. & $\begin{array}{l}\text { make you feel like a partner in your child's } \\
\text { care? }\end{array}$ & $\begin{array}{l}\text {... fazem você se sentir um parceiro no tratamento } \\
\text { de seu filho? }\end{array}$ & - \\
\hline 37. & $\begin{array}{l}\text { make sure you are informed ahead of time } \\
\text { about any changes in your child's care (e.g., } \\
\text { therapists, programs, equipment)? }\end{array}$ & $\begin{array}{l}\text {... certificam que você está informado antes do } \\
\text { tempo sobre quaisquer mudanças nos cuidados } \\
\text { do seu filho (por exemplo, terapeutas, programas } \\
\text { e equipamentos)? }\end{array}$ & $\begin{array}{l}\text {... certificam que você está informado antes de } \\
\text { quaisquer mudanças nos cuidados do seu filho (por } \\
\text { exemplo, terapeutas, programas e equipamentos)? }\end{array}$ \\
\hline 38. & help you to feel competent as a parent? & $\begin{array}{l}\text {... auxiliam você a se sentir competente enquanto } \\
\text { responsável pela criança? }\end{array}$ & - \\
\hline 39. & $\begin{array}{l}\text { provide you with written information about } \\
\text { your child's progress? }\end{array}$ & $\begin{array}{l}\text {... fornecem informações escritas do progresso do } \\
\text { seu filho? }\end{array}$ & - \\
\hline 40. & $\begin{array}{l}\text { seem aware of your child's changing needs } \\
\text { as he/she grows? }\end{array}$ & $\begin{array}{l}\text {... se preocupam com as mudanças do seu filho } \\
\text { enquanto cresce? }\end{array}$ & $\begin{array}{l}\text {... se preocupam com as necessidades que mudam } \\
\text { conforme seu filho cresce? }\end{array}$ \\
\hline 41. & $\begin{array}{l}\text { provide enough time to talk so you don't feel } \\
\text { rushed? }\end{array}$ & $\begin{array}{l}\text {... tem disponibilidade de horário para atender a } \\
\text { você? }\end{array}$ & $\begin{array}{l}\text {... fornecem tempo suficiente para conversar com } \\
\text { você de modo que você não se sinta apressado? }\end{array}$ \\
\hline
\end{tabular}


continuação

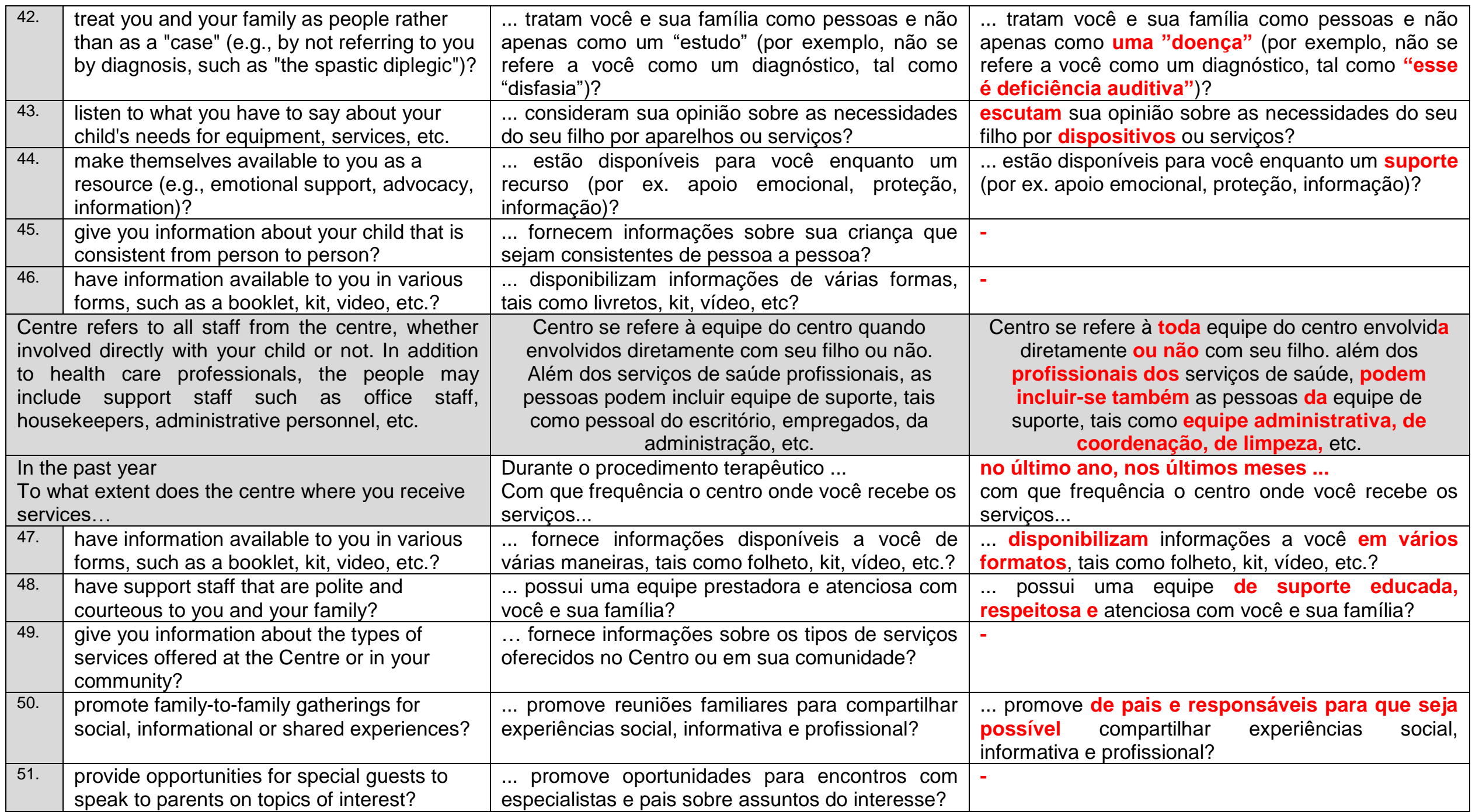


continuação

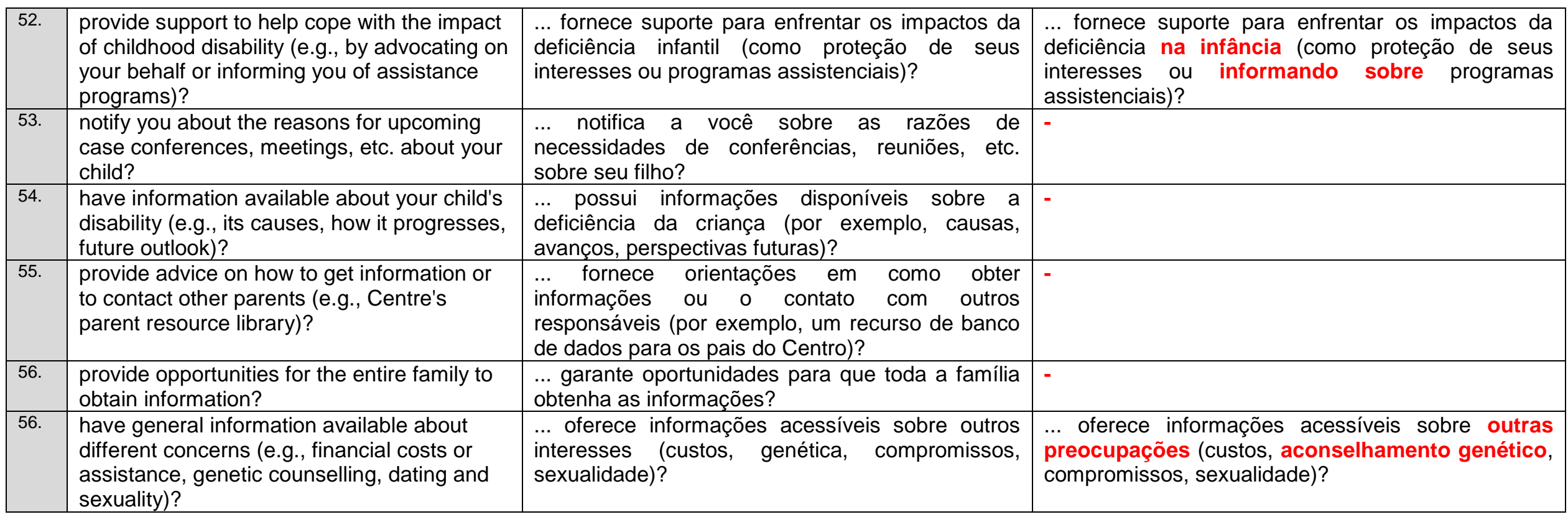


Tabela 2 Resultados da análise do segundo perito.

\begin{tabular}{|c|c|c|}
\hline$\overline{\mathbf{A L}}$ & JÇÃO & 2 \\
\hline ased on wh & $\begin{array}{l}\text { Gostaríamos de avaliar as experiências dos } \\
\text { pais que possuem filho(a) com alguma deficiência. } \\
\text { Em especial, gostaríamos de saber as considerações } \\
\text { quanto ao atendimento que ele(a) tem recebido nos } \\
\text { últimos meses no Centro de Tratamento } \\
\text { (Reabilitação). } \\
\text { As questões nesta sessão são referentes } \\
\text { ao que os pais, iguais a você, têm a dizer a respeito } \\
\text { do serviço oferecido. Pedimos que você aponte a } \\
\text { frequência com que um acontecimento ou situação } \\
\text { ocorre (ou não) no centro de tratamento } \\
\text { (reabilitação). Cada questão possui uma escala do } 1 \\
\text { (nunca) ao } 7 \text { (Sempre). } \\
\text { O tratamento que você e seu(sua) filho(a) } \\
\text { receberam do Centro possibilita o contato com } \\
\text { muitos indivíduos. Dessa forma, as questões estão } \\
\text { agrupadas de modo a indicar quem são esses }\end{array}$ & $\begin{array}{l}\text { de entender e avaliar as } \\
\text { ue possuem filho(a) com alguma } \\
\text { ial, gostaríamos de saber as } \\
\text { ao atendimento que ele(a) tem } \\
\text { o último ano no Centro de } \\
\text { ão). } \\
\text { hesta sessão são referentes ao } \\
\text { ocê, têm a dizer a respeito do } \\
\text { dimos que você aponte a } \\
\text { um acontecimento ou situação } \\
\text { tro de tratamento (reabilitação). } \\
\text { questão em uma escala do } 1 \\
\text { que você e seu (sua) filho(a) } \\
\text { ossibilita o contato com muitos } \\
\text { a, as questões estão agrupadas } \\
\text { ñ são esses contatos, descritos }\end{array}$ \\
\hline $\begin{array}{l}\text { The following is } \\
\text { question } \\
\text { This example al }\end{array}$ & $\begin{array}{l}\text { o. } \\
\text { es } \\
\text { o, } \\
\text { m } \\
\text { be } \\
\text { m to }\end{array}$ & $\begin{array}{r}\text { Abaixo est } \\
\text { Es } \\
\text { resposta por }\end{array}$ \\
\hline
\end{tabular}


continuação

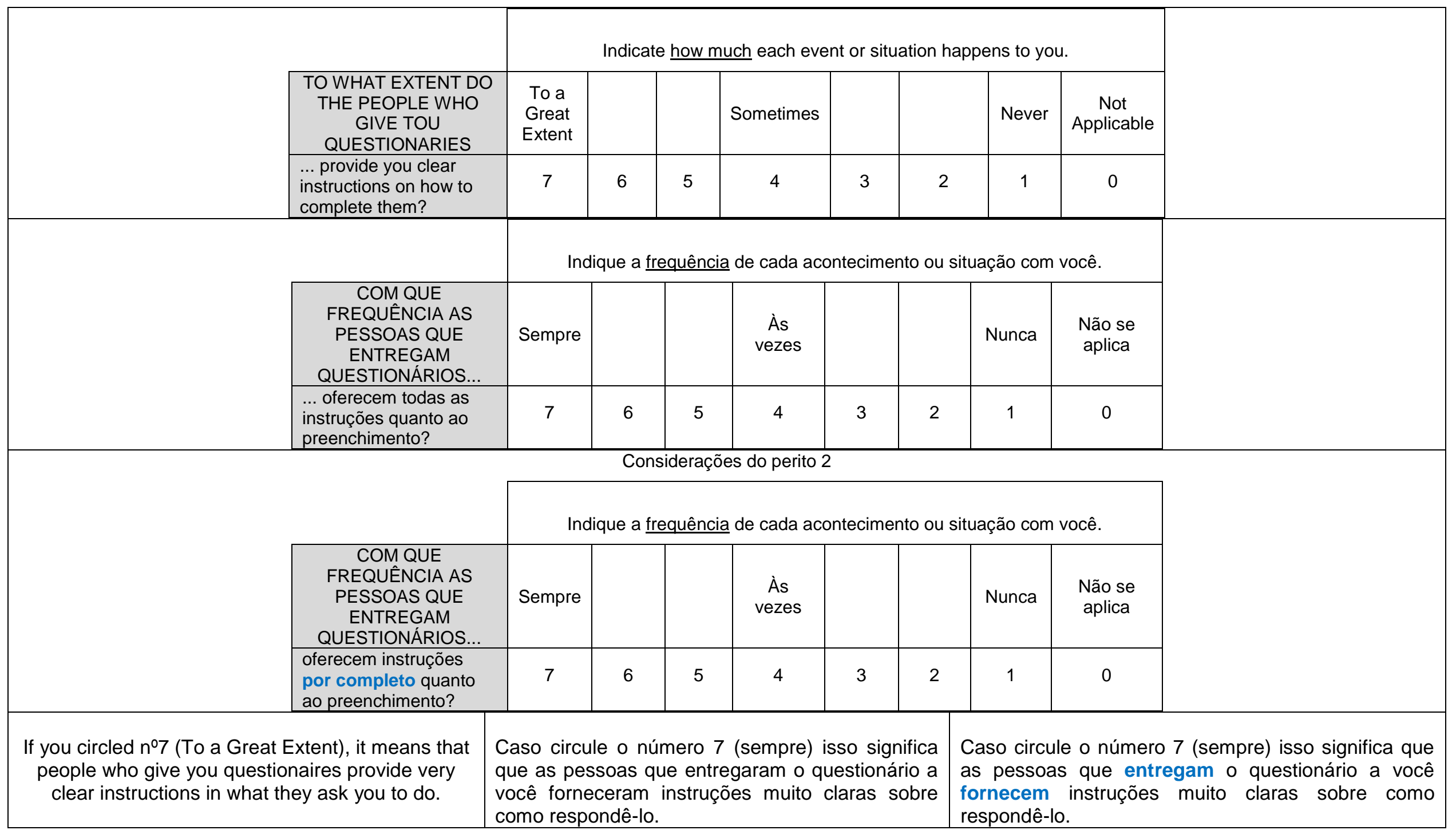


continuação

If you circled $\mathrm{n}^{\circ} 4$ (Sometimes), it means that the people who give you questionnaires are clear in what they want you to some of the time, and some of the time the instructions are not clear.

If you circled $n-1$ (Never), it means that although you have received questionnaires, the instructions are never clear.

If you circled $\mathrm{n}-0$ (Not Applicable), it means that you have never received a questionnaire and so you cannot answer the question. It does not apply to you.

We would like you to think about your experiences over the past year child's Centre. We are interested in your personal thoughts and would appreciate your completing this questionnaire on your own without discussing it with anyone.

For each question, please indicate how much the event or situation happens to you by circling one number (from 1 to 7 ) that you feel best fits your experience. When answering these questions, we would like to you to think about the Centre from which you first found about this study.

For easy reference, we have written the name of that Centre on this line:

People refers to those individuals who work directly with you or your child. These may include teachers, psychologists, therapists, social workers, doctors, etc.

IN THE PAST YEAR
Caso circule o número 4 (às vezes) significa que as pessoas que entregaram o questionário a você forneceram instruções objetivas sobre o que queriam que você fizesse, mas não relacionado ao significado específico das perguntas.

Caso circule o número 1 (nunca), isso significa que, embora tenha recebido o questionário, as instruções não foram transmitidas adequadamente.

Caso circule o número 0 (não se aplica), isso significa que você nunca recebeu um questionário e, por conseguinte, não foi capaz de responder as questões, isto é, esse questionário não se aplica você ou a sua realidade.

Gostaríamos que você pensasse sobre as experiências vividas nos últimos meses com seu filho no Centro. Estamos interessados em sua opinião para completar esse questionário que é de caráter confidencial.

Por favor, para cada questão indique a frequência da ocorrência, circule apenas um número (de 1 a 7) que melhor descreve a sua experiência. Enquanto responde a essas questões, gostaríamos que você pensasse também no Centro em que se realiza esse estudo.

Para facilitar, preenchemos o nome do Centro nesta linha:

Pessoas se referem àqueles indivíduos que trabalham diretamente com você ou seu filho. Esses podem incluir professores, psicólogos, terapeutas, assistentes sociais, médicos, etc.

Durante o procedimento terapêutico
Caso circule o número 4 (às vezes) significa que as pessoas que entregam o questionário a você fornecem instruções claras sobre o que queriam que você fizesse em parte, mas para o resto as instruções não foram claras.

Caso circule o número 1 (nunca), isso significa que, embora tenha recebido o questionário, as instruções não foram claras.

Caso circule o número 0 (não se aplica), isso significa que você nunca recebeu um questionário $e$, por conseguinte, não foi pode responder as questões, isto é, esse questionário não se aplica a você ou a sua realidade.

Gostaríamos que você pensasse sobre as experiências vividas nos últimos meses com seu filho no Centro. Estamos interessados em sua opinião e gostaríamos que você completasse o questionário sem discutir com outras pessoas.

Por favor, para cada questão indique a frequência com que a situação ou evento acontece com você circule apenas um número (de 1 a 7) que melhor descreva a sua experiência. Enquanto responde a essas questões, gostaríamos que você pensasse no centro em que seu filho (a) é acompanhado.

Para nossa referência, escreva o nome do centro nesta linha: 
continuação

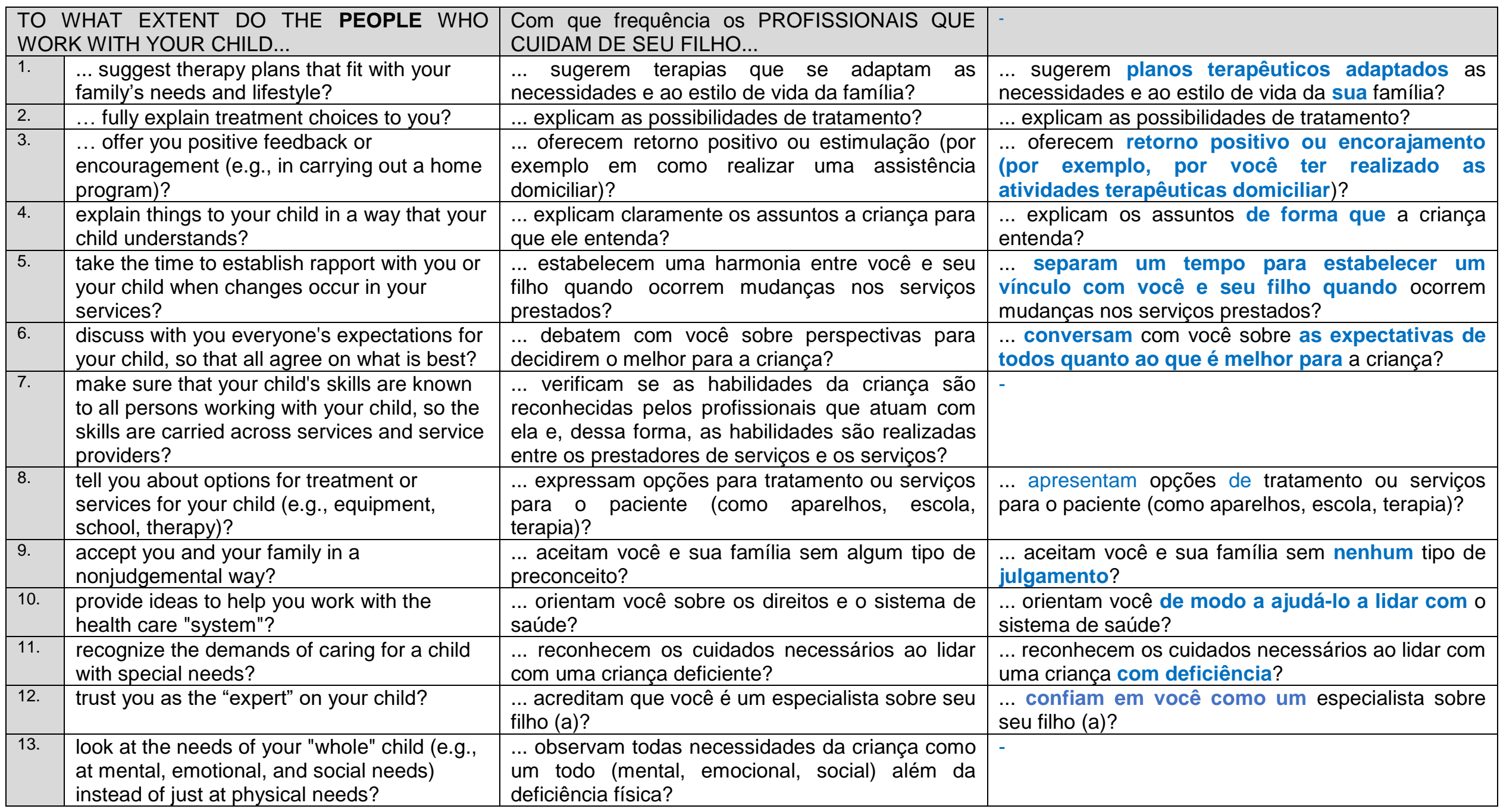


continuação




continuação

\begin{tabular}{|c|c|c|c|}
\hline 29. & $\begin{array}{l}\text { provide a caring atmosphere rather than just } \\
\text { give you information? }\end{array}$ & $\begin{array}{l}\text {... proporcionam um ambiente acolhedor ao invés } \\
\text { de dar somente informações? }\end{array}$ & - \\
\hline 30. & $\begin{array}{l}\text { tell you details about your child's services, } \\
\text { such as the reasons for them, the type of } \\
\text { therapies and the length of time? }\end{array}$ & $\begin{array}{l}\text {... informam detalhes sobre serviços a seu filho, } \\
\text { tais como razões, tipo de terapias e duração? }\end{array}$ & $\begin{array}{l}\text {... informam detalhes dos serviços realizados com } \\
\text { seu filho, como por exemplo, as razões para } \\
\text { indicá-los, os tipos de terapias e duração? }\end{array}$ \\
\hline 31. & $\begin{array}{l}\text { treat you as an individual rather than as a } \\
\text { "typical" parent of a child with a disability? }\end{array}$ & $\begin{array}{l}\text {... tratam você diferente por ser um responsável } \\
\text { "típico" de uma criança deficiente? }\end{array}$ & $\begin{array}{l}\text {... tratam você como um indivíduo qualquer ao } \\
\text { invés de um responsável por uma criança com } \\
\text { deficiência? }\end{array}$ \\
\hline 32. & $\begin{array}{l}\text { develop both short-term and long-term goals } \\
\text { for your child? }\end{array}$ & $\begin{array}{l}\text {... estabelecem metas a curto e longo prazo para } \\
\text { seu filho? }\end{array}$ & 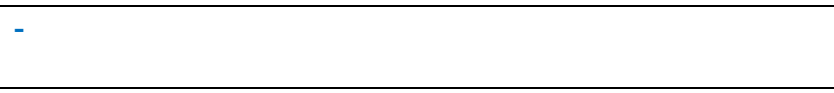 \\
\hline 33. & $\begin{array}{l}\text { treat you as an equal rather than just as the } \\
\text { parent of a patient (e.g.,,by not referring to } \\
\text { you as "Mom" or "Dad")? }\end{array}$ & $\begin{array}{l}\text {... tratam você com igualdade sem chamar apenas } \\
\text { de responsável pelo paciente (por exemplo não se } \\
\text { refere a você como "pai" ou "mãe)"? }\end{array}$ & $\begin{array}{l}\text {... tratam você pelo seu nome sem se referir a você } \\
\text { apenas como responsável pelo paciente (por } \\
\text { exemplo não se refere a você como "pai" ou "mãe")? }\end{array}$ \\
\hline 34. & $\begin{array}{l}\text { plan together so they are all working in the } \\
\text { same direction? }\end{array}$ & $\begin{array}{l}\ldots \text { planejam o tratamento juntos para que } 0 \\
\text { mesmo objetivo seja trabalhado? }\end{array}$ & - \\
\hline 35. & $\begin{array}{l}\text { make sure you have opportunities to explain } \\
\text { what you think are important treatment } \\
\text { goals? }\end{array}$ & $\begin{array}{l}\text {... garantem a você oportunidades para que opine } \\
\text { sobre os objetivos do tratamento? }\end{array}$ & - \\
\hline 36. & $\begin{array}{l}\text { make you feel like a partner in your child's } \\
\text { care? }\end{array}$ & $\begin{array}{l}\text {... fazem você se sentir um parceiro no tratamento } \\
\text { de seu filho? }\end{array}$ & - \\
\hline 37. & $\begin{array}{l}\text { make sure you are informed ahead of time } \\
\text { about any changes in your child's care (e.g., } \\
\text { therapists, programs, equipment)? }\end{array}$ & $\begin{array}{l}\text {... certificam que você está informado antes do } \\
\text { tempo sobre quaisquer mudanças nos cuidados } \\
\text { do seu filho (por exemplo, terapeutas, programas } \\
\text { e equipamentos)? }\end{array}$ & $\begin{array}{l}\text {... certificam que você está informado antes de } \\
\text { quaisquer mudanças nos cuidados do seu filho (por } \\
\text { exemplo, terapeutas, programas e equipamentos)? }\end{array}$ \\
\hline 38. & help you to feel competent as a parent? & $\begin{array}{l}\text {... auxiliam você a se sentir competente enquanto } \\
\text { responsável pela criança? }\end{array}$ & - \\
\hline 39. & $\begin{array}{l}\text { provide you with written information about } \\
\text { your child's progress? }\end{array}$ & $\begin{array}{l}\text {... fornecem informações escritas do progresso do } \\
\text { seu filho? }\end{array}$ & - \\
\hline 40. & $\begin{array}{l}\text { seem aware of your child's changing needs } \\
\text { as he/she grows? }\end{array}$ & $\begin{array}{l}\text {... se preocupam com as mudanças do seu filho } \\
\text { enquanto cresce? }\end{array}$ & $\begin{array}{l}\text {... se preocupam com as necessidades conforme } \\
\text { seu filho cresce? }\end{array}$ \\
\hline 41. & $\begin{array}{l}\text { provide enough time to talk so you don't feel } \\
\text { rushed? }\end{array}$ & $\begin{array}{l}\ldots \text { tem disponibilidade de horário para atender a } \\
\text { você? }\end{array}$ & $\begin{array}{l}\text {... têm tempo suficiente para conversar com você } \\
\text { de modo que não se sinta apressado? }\end{array}$ \\
\hline 42. & $\begin{array}{l}\text { treat you and your family as people rather } \\
\text { than as a "case" (e.g., by not referring to you } \\
\text { by diagnosis, such as "the spastic diplegic")? }\end{array}$ & $\begin{array}{l}\text {... tratam você e sua família como pessoas e não } \\
\text { apenas como um "estudo" (por exemplo, não se } \\
\text { refere a você como um diagnóstico, tal como } \\
\text { "disfasia")? }\end{array}$ & $\begin{array}{l}\text {... tratam você e sua família como pessoas e não } \\
\text { apenas como uma "doença" (por exemplo, não se } \\
\text { refere a você como um diagnóstico, tal como "esse } \\
\text { é deficiência auditiva")? }\end{array}$ \\
\hline
\end{tabular}


continuação

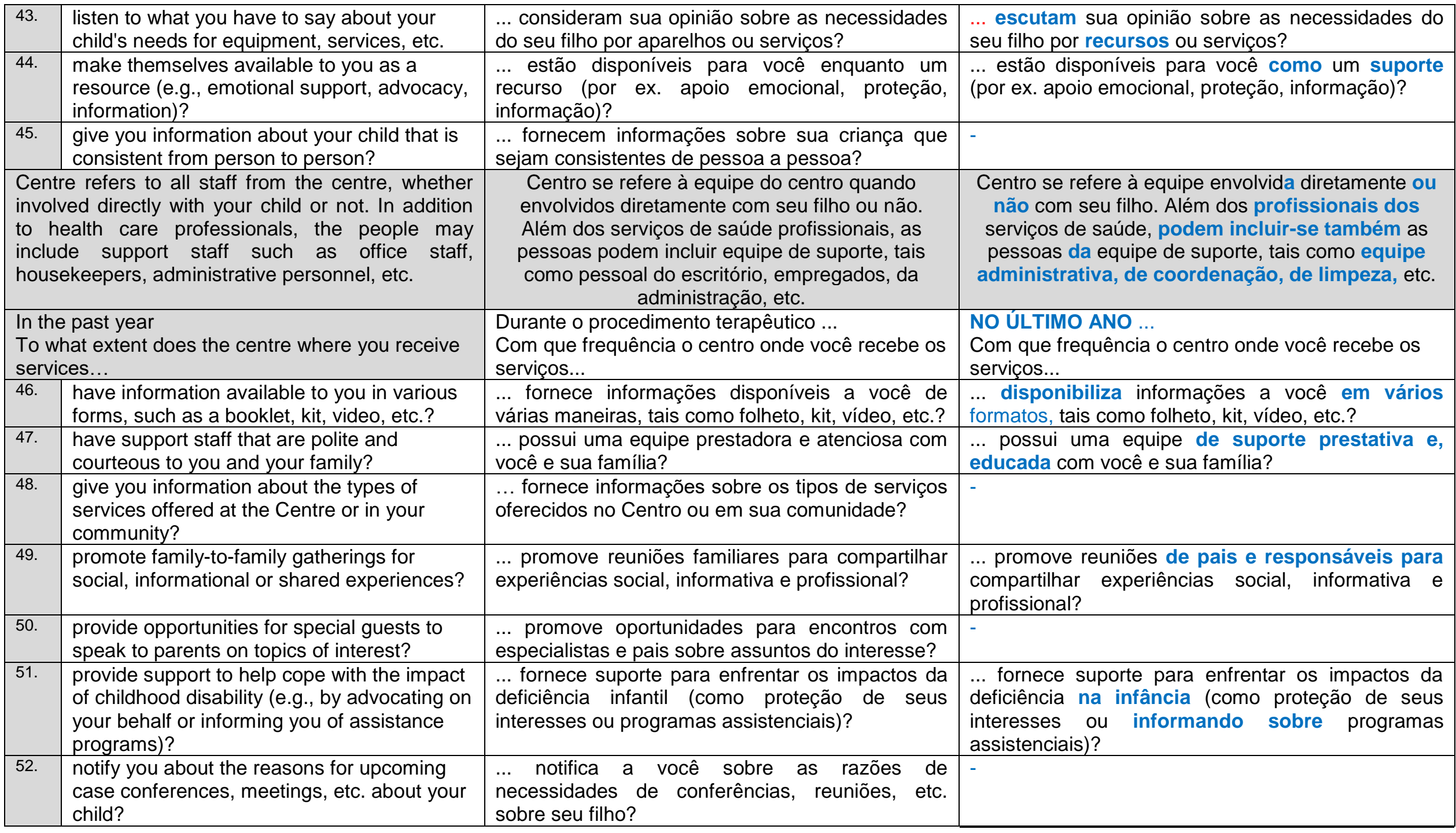


continuação

\begin{tabular}{|l|l|l|l|}
\hline 53. & $\begin{array}{l}\text { have information available about your child's } \\
\text { disability (e.g., its causes, how it progresses, } \\
\text { future outlook)? }\end{array}$ & $\begin{array}{l}\ldots \text { possui informações disponíveis sobre a } \\
\text { deficiência da criança (por exemplo, causas, } \\
\text { avanços, perspectivas futuras)? }\end{array}$ & - \\
\hline 54. & $\begin{array}{l}\text { provide advice on how to get information or } \\
\text { to contact other parents (e.g., Centre's } \\
\text { parent resource library)? }\end{array}$ & $\begin{array}{l}\text { fornece orientações em como obter } \\
\text { informaçóes ou o contato com outros } \\
\text { responsáveis (por exemplo, um recurso de banco } \\
\text { de dados para os pais do Centro)? }\end{array}$ & - \\
\hline 55. & $\begin{array}{l}\text { provide opportunities for the entire family to } \\
\text { obtain information? }\end{array}$ & $\begin{array}{l}\ldots \text { garante oportunidades para que toda a família } \\
\text { obtenha as informações? }\end{array}$ & - \\
\hline 56. & $\begin{array}{l}\text { have general information available about } \\
\text { different concerns (e.g., financial costs or } \\
\text { assistance, genetic counselling, dating and } \\
\text { sexuality)? }\end{array}$ & $\begin{array}{l}\ldots \text { oferece informações acessíveis sobre outros } \\
\text { interesses (custos, genética, compromissos, } \\
\text { sexualidade)? }\end{array}$ & $\begin{array}{l}\ldots \text { oferece informações acessíveis sobre outras } \\
\text { preocupacónes (custos, aconselhamento genético, } \\
\text { compromissos, sexualidade)? }\end{array}$ \\
\hline
\end{tabular}


Tabela 3 Consenso sobre a tradução do questionário na etapa do brainstorming.

\section{CONSIDERAÇÕES DO PERITO 1}

Gostaríamos de entender e avaliar as experiências dos pais que possuem filho(a) com alguma deficiência. Em especial, gostaríamos de saber as considerações quanto ao atendimento que ele(a) tem recebido no último ano? no Centro de Tratamento (Reabilitação)

As questões nesta sessão são referentes ao que os pais, como vocês, têm a dizer a respeito do serviço oferecido. Pedimos que você aponte a frequência com que um acontecimento ou situação ocorre (ou não) no centro de tratamento (reabilitação). Você deverá responder cada questão em uma escala do 1 (nunca) ao 7 (Sempre).

O tratamento que você e seu(sua) filho(a) receberam do Centro possibilita o contato com muitos indivíduos. Dessa forma, as questões estão agrupadas de modo a indicar quem são esses contatos, descritos abaixo.

1. PESSOAS: Se refere àqueles indivíduos que trabalham diretamente com você ou seu filho (a). Podem incluir psicólogos, terapeutas, assistentes sociais, médicos, professores, etc.

2. INSTITUIÇÃO: Se refere a toda equipe do centro, envolvida diretamente ou não com seu filho (a). Além das pessoas do centro de tratamento, equipe também pode incluir grupos de apoio, tais como, pessoas que trabalham no escritório, serviços gerais, departamento administrativo, etc.

Abaixo está um exemplo do tipo de pergunta presente no questionário.

Esse exemplo também mostra o que a sua resposta pode significar.

\section{CONSIDERAÇÕES DO PERITO 2}

Gostaríamos de entender e avaliar as experiências dos pais que possuem filho(a) com alguma deficiência. Em especial, gostaríamos de saber as considerações quanto ao atendimento que ele(a) tem recebido ao longo do último ano no Centro de Tratamento (Reabilitação).

As questões nesta sessão são referentes o que os pais, iguais a você, têm a dizer a respeito do serviço oferecido. Pedimos que você aponte a frequência com que um acontecimento ou situação ocorre (ou não) no centro de tratamento (reabilitação). Você responderá cada questão em uma escala do 1 (nunca) ao 7 (Sempre).

O tratamento que você e seu (sua)

filho(a) receberam do Centro possibilita o contato com muitos indivíduos. Dessa forma, as questões estão agrupadas de modo a indicar quem são esses contatos, descritos abaixo.

PESSOAS: Se refere àqueles indivíduos que trabalham diretamente com você ou seu filho (a). Podem incluir psicólogos, terapeutas, assistentes sociais, médicos, professores, etc.

2. INSTITUIÇÃO: Se refere a toda equipe do centro, envolvida diretamente ou não com seu filho (a). Além das pessoas do centro de tratamento, a equipe também pode incluir grupos de apoio, tais como, pessoas que trabalham no escritório, serviços gerais, departamento administrativo, etc.

Abaixo está um exemplo do tipo de pergunta presente no questionário.

Esse exemplo também mostra o que a sua resposta pode significar.
CONSENSO DOS PERITOS E DA TRADUTORA

Gostaríamos de entender e avaliar as experiências dos pais que possuem filho(a) com alguma deficiência. Em especial, gostaríamos de saber as considerações quanto ao atendimento que ele(a) tem recebido no último ano no Centro de Tratamento (Reabilitação).

As questões nesta sessão são referentes ao que os pais, iguais a você, têm a dizer a respeito do serviço oferecido. Pedimos que você aponte a frequência com que um acontecimento ou situação ocorre (ou não) no centro de tratamento (reabilitação). Você responderá a cada questão em uma escala do 1 (nunca) ao 7 (Sempre).

O tratamento que você e seu (sua) filho(a) receberam do Centro possibilita o contato com muitos indivíduos. Dessa forma, as questões estão agrupadas de modo a indicar quem são esses contatos, descritos abaixo.

PESSOAS: Se refere àqueles indivíduos que rabalham diretamente com você ou seu filho (a) Podem incluir psicólogos, terapeutas, assistentes sociais, médicos, professores, etc.

2. INSTITUIÇÃO: Se refere a toda equipe do centro, envolvida diretamente ou não com seu filho (a). Além das pessoas do centro de tratamento, a equipe pode incluir grupos de apoio, tais como, pessoas que trabalham no escritório, serviços gerais, departamento administrativo, etc.

Abaixo está um exemplo do tipo de pergunta presente no questionário.

Esse exemplo também mostra o que a sua resposta pode significar. 
continuação

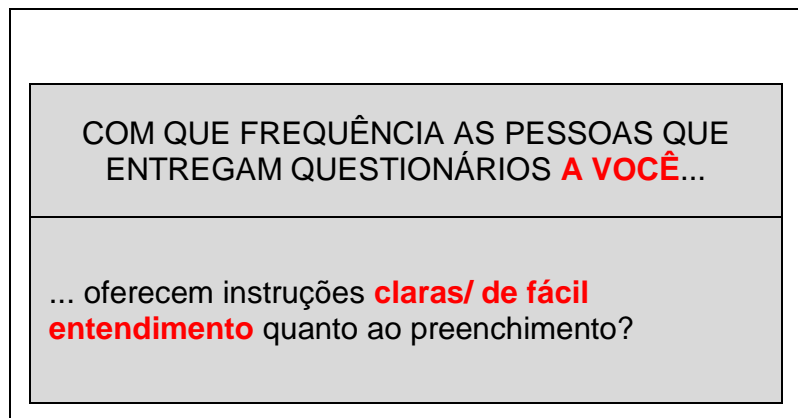

Caso circule o número 4 (às vezes) significa que as pessoas que entregaram o questionário a você forneceram instruções claras sobre o que queriam que você fizesse em parte, mas para o resto as instruções não foram claras.

Caso circule o número 1 (nunca), isso significa que, embora tenha recebido o questionário, as instruções não foram claras.

Caso circule o número 0 (não se aplica), isso significa que você nunca recebeu um questionário e, por conseguinte, não foi consegue responder as questões, isto é, esse questionário não se aplica a você ou a sua realidade.

Gostaríamos que você pensasse sobre as experiências vividas nos últimos meses com seu filho no Centro. Estamos interessados em sua opinião e gostaríamos que você completasse o questionário sozinho, sem discutir com outras pessoas.
COM QUE FREQUÊNCIA AS PESSOAS QUE ENTREGAM QUESTIONÁRIOS...

... oferecem instruções por completo quanto ao preenchimento?

Caso circule o número 4 (às vezes) significa que as pessoas que entregam o questionário a você fornecem instruções claras sobre o que queriam que você fizesse em parte, mas para o resto as instruções não foram claras.

Caso circule o número 1 (nunca), isso significa que, embora tenha recebido o questionário, as instruções não foram claras.

Caso circule o número 0 (não se aplica), isso significa que você nunca recebeu um questionário e, por conseguinte, não pode responder as questões, isto é, esse questionário não se aplica a você ou a sua realidade.

Gostaríamos que você pensasse sobre as experiências vividas nos últimos meses com seu filho no Centro. Estamos interessados em sua opinião e gostaríamos que você completasse o questionário sem discutir com outras pessoas.
COM QUE FREQUÊNCIA AS PESSOAS QUE ENTREGAM QUESTIONÁRIOS A VOCÊ...

oferecem instruções claras quanto ao preenchimento?

Caso circule o número 4 (às vezes) significa que as pessoas que entregam questionário a você fornecem instruções claras sobre o que querem que você faça em parte, mas para o restante, as instruções não foram claras.

Caso circule o número 1 (nunca), isso significa que, embora tenha recebido o questionário, as instruções não foram claras.

Caso circule o número 0 (não se aplica), isso significa que você nunca recebeu um questionário e, por conseguinte, não pode responder as questões, isto é, esse questionário não se aplica a você ou a sua realidade.

Gostaríamos que você pensasse sobre as experiências vividas no último ano com seu filho no Centro. Estamos interessados em sua opinião e gostaríamos que você completasse o questionário sem conversar com outras pessoas. 
continuação

Por favor, para cada questão indique a frequência com que a situação ou evento acontece com você, circule apenas um número (de 1 a 7) que melhor descreva a sua experiência. Enquanto responde a essas questões, gostaríamos que você pensasse no centro em que seu filho é acompanhado.

Para nossa referência, escreva o nome do centro nesta linha:

NO ULTIMO ANO.... OU NOS ULTIMOS MESES ... sugerem planos terapêuticos ajustados as necessidades e ao estilo de vida da família? OK

... oferecem reforço positivo ou incentivo (por exemplo, realizando visitas e assistências em sua casa)?

... explicam os assuntos de uma forma que a criança entenda?

... separam um período para estabelecer um vinculo com você e seu filho quando ocorrem mudanças nos serviços prestados?

... debatem com você sobre as expectativas de todos ao seu redor e se todos concordam quanto ao que é melhor para a criança?
Por favor, para cada questão indique a frequência com que a situação ou evento acontece com você, circule apenas um número (de 1 a 7) que melhor descreva a sua experiência. Enquanto responde a essas questões, gostaríamos que você pensasse no centro em que seu filho (a) é acompanhado.

Para nossa referência, escreva o nome do centro nesta linha:

\section{NO ULTIMO ANO}

... sugerem planos terapêuticos adaptados as necessidades e ao estilo de vida da sua família? OK

.. oferecem retorno positivo ou encorajamento (por exemplo, por você ter realizado as atividades terapêuticas domiciliar)?

... explicam os assuntos de forma que a criança entenda?

. separam um tempo para estabelecer um vínculo com você e seu fillho quando ocorrem mudanças nos serviços prestados?

... conversam com você sobre as expectativas de todos quanto ao que é melhor para a criança?
Por favor, para cada questão indique a frequência com que cada situação ou evento aconteceu com você, circule apenas um número (de 1 a 7) que melhor descreva a sua experiência. Enquanto responde a essas questões, gostaríamos que você pensasse no centro em que seu filho (a) é acompanhado.

Para nossa referência, escreva o nome do centro nesta linha:

Pessoas se referem àqueles indivíduos que
trabalham diretamente com você ou seu filho. Esses podem incluir professores, psicólogos, terapeutas, assistentes sociais, médicos, etc.

NO ULTIMO ANO ..

... sugerem planos terapêuticos adaptados as necessidades e ao estilo de vida da sua família?

explicam completamente as possibilidades de tratamento?

. oferecem a você retorno positivo ou incentivo (por exemplo, por você realizar as atividades terapêuticas em sua casa)?

explicam os assuntos de forma que seu (sua) filho (a) entenda?

.. separam um tempo para estabelecer um vínculo com você e seu filho quando ocorrem mudanças nos serviços prestados?

... conversam com você sobre as expectativas de todos quanto ao que é melhor para a criança?

... verificam se as habilidades da criança são reconhecidas pelos profissionais que atuam com ela e, dessa forma, são realizadas entre os prestadores de serviços e os serviços? 
continuação

... conversam sobre as opções de tratamento ou serviços para o paciente (como aparelhos, escola, terapia)?

... aceitam você e sua família sem nenhum tipo de julgamento?

... orientam você de modo a ajudá-lo a lidar com o sistema de saúde?

... reconhecem os cuidados necessários ao lidar com uma criança com deficiência?

$-$

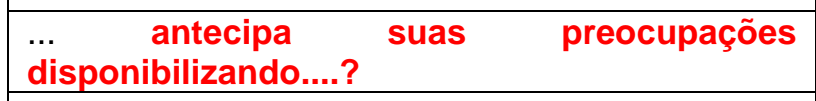

$-$

... explicam as razões para um tratamento ou indicação de dispositivos?

... acompanham no próximo atendimento suas dúvidas e preocupações discutidas anteriormente?

... asseguram que ao menos um membro da equipe seja alguém que já trabalha com você e sua família há um longo período?
... apresentam opções de tratamento ou serviços para o paciente (como aparelhos, escola, terapia)?

... aceitam você e sua família sem nenhum tipo de julgamento?

orientam você de modo a ajudá-lo a lidar com o sistema de saúde?

... reconhecem os cuidados necessários ao lidar com uma criança com deficiência?

... confiam em você como um especialista sobre seu filho (a)?

.. antecipam informações e prestam auxílio antes mesmo de você pedir?

$-$
recursos?

... dão continuidade no próximo atendimento a assuntos discutidos previamente?

... asseguram que pelo menos um membro da equipe já tenha trabalhado com você e sua família há um longo período? apresentam opções de tratamento ou serviços para o paciente (como aparelhos, escola, terapia)?

.. aceitam você e sua família sem nenhum tipo de julgamento?

orientam você de modo a ajudá-lo a lidar com o sistema de saúde? uma criança com deficiência?

... confiam em você como um especialista sobre seu filho (a)?

... observam todas necessidades da criança como um todo (mental, emocional, social) além da deficiência física?

... demonstram sensibilidade com os sentimentos da família em ter um filho com deficiência (por exemplo, suas preocupações com a saúde do seu filho ou funções? mesmo de você pedir? ... certificam que você tem oportunidades durante as visitas ao centro para dizer o que é importante para você?

... permitem que você peça informações e como as deseja receber?

lembram de detalhes pessoais da criança ou da família quando conversam com você?

explicam as razões para um tratamento ou recursos auxiliares?

. assuntos discutidos previamente?

... asseguram que pelo menos um membro da equipe já tenha trabalhado com você e sua família há um longo período? 
continuação

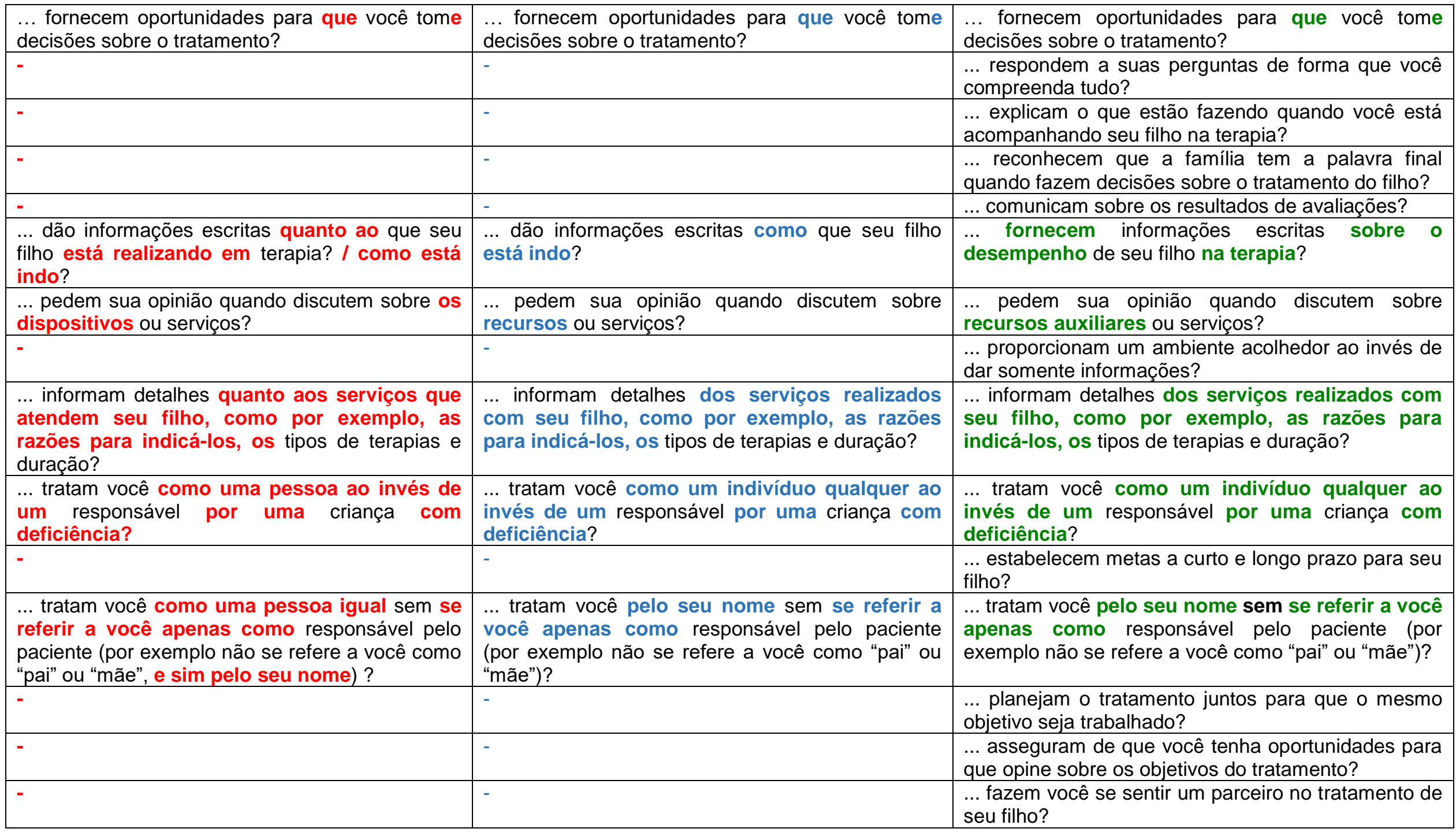


continuação

... certificam que você está informado antes de quaisquer mudanças nos cuidados do seu filho (por exemplo, terapeutas, programas equipamentos)?

se preocupam com as necessidades que mudam conforme seu filho cresce?

... fornecem tempo suficiente para conversar com você de modo que você não se sinta apressado?

... tratam você e sua família como pessoas e não apenas como uma "doença" (por exemplo, não se refere a você como um diagnóstico, tal como "esse é deficiência auditiva")?

.. escutam sua opinião sobre as necessidades do seu filho por dispositivos ou serviços? estão disponíveis para você enquanto um suporte (por ex. apoio emocional, proteção, informação)?

Centro se refere à toda equipe do centro envolvida diretamente ou não com seu filho. Além dos profissionais dos serviços de saúde, podem incluir-se também as pessoas da equipe de suporte, tais como equipe administrativa, de coordenação, de limpeza, etc. certificam que você está informado antes de quaisquer mudanças nos cuidados do seu filho (por exemplo, terapeutas, programas e equipamentos)?

-

preocupam com as necessidades conforme seu filho cresce?

tem tempo suficiente para conversar com você de modo que não se sinta apressado?

... tratam você e sua família como pessoas e não apenas como uma "doenç" (por exemplo, não se refere a você como um diagnóstico, ta como "esse é deficiência auditiva")?

escutam sua opinião sobre as necessidades do seu filho por recursos ou serviços?

estão disponíveis para você como um suporte (por ex. apoio emocional, proteção, informação)?

... sugerem terapias que se adaptam as necessidades e ao estilo de vida da sua família? Centro se refere à equipe envolvida diretamente ou não com seu filho. Além dos profissionais dos serviços de saúde, podem incluir-se também as pessoas da equipe de suporte, tais como equipe administrativa, de coordenação, de limpeza, etc. certificam que você está informado antes de quaisquer mudanças nos cuidados do seu filho (por exemplo, terapeutas, programas e equipamentos)?

... auxiliam você a se sentir competente enquanto responsável pela criança?

fornecem informações escritas do progresso do seu filho?

se preocupam com as necessidades conforme seu filho cresce?

tem tempo suficiente para conversar com você de modo que não se sinta apressado?

... tratam você e sua família como pessoas e não apenas como uma "doença" (por exemplo, não se refere a você como um diagnóstico, tal como "esse é deficiência auditiva" ou outra?

escutam o que você tem a dizer sobre as necessidades do seu filho por recursos auxiliares ou serviços?

estão disponíveis para você como um suporte (por ex. apoio emocional, proteção, informação)?

... fornecem informações sobre sua criança que sejam consistentes de pessoa a pessoa?

... sugerem terapias que se adaptam as necessidades e ao estilo de vida da sua família?

Centro se refere à equipe envolvida diretamente ou não com seu filho. Além dos profissionais dos serviços de saúde, podem incluir-se também as pessoas da equipe

de suporte, tais como equipe administrativa, de coordenação, de limpeza, etc. 
continuação

\begin{tabular}{|c|c|c|}
\hline $\begin{array}{l}\text { NO ULTIMO ANO, NOS ULTIMOS } \\
\text { MESES ... - }\end{array}$ & NO ULTIMO ANO ... & $\begin{array}{l}\text { NO ULTIMO ANO ... } \\
\text { Com que frequência o centro onde você recebe os } \\
\text { serviços... }\end{array}$ \\
\hline & $\begin{array}{l}\ldots \text { disponibiliza informações a você em vários } \\
\text { formatos, tais como folheto, kit, vídeo, etc.? }\end{array}$ & $\begin{array}{l}\ldots \text { disponibiliza informações a você em vários } \\
\text { formatos, tais como folheto, kit, vídeo, etc.? }\end{array}$ \\
\hline- & - & $\begin{array}{l}\ldots \text { fornece informações sobre os tipos de serviços } \\
\text { oferecidos no Centro ou em sua comunidade? }\end{array}$ \\
\hline $\begin{array}{l}\text {... promove de pais e responsáveis para que } \\
\text { seja possível compartilhar experiências social, } \\
\text { informativa e profissional? }\end{array}$ & $\begin{array}{l}\text {... promove reuniões de pais e responsáveis para } \\
\text { compartilhar experiências social, informativa e } \\
\text { profissional? }\end{array}$ & $\begin{array}{l}\text {... promove reuniões de pais e responsáveis para } \\
\text { compartilhar experiências social, informativa e } \\
\text { profissional? }\end{array}$ \\
\hline- & - & $\begin{array}{l}\text {.. promove oportunidades para encontros com } \\
\text { especialistas e pais sobre assuntos do interesse? }\end{array}$ \\
\hline $\begin{array}{l}\text {... fornece suporte para enfrentar os impactos da } \\
\text { deficiência na infância (como proteção de seus } \\
\text { interesses ou informando sobre programas } \\
\text { assistenciais)? }\end{array}$ & $\begin{array}{l}\text {... fornece suporte para enfrentar os impactos da } \\
\text { deficiência na infância (como proteção de seus } \\
\text { interesses ou informando sobre programas } \\
\text { assistenciais)? }\end{array}$ & $\begin{array}{l}\text {... fornece suporte para enfrentar os impactos da } \\
\text { deficiência na infância (como proteção de seus } \\
\text { interesses ou informando sobre programas } \\
\text { assistenciais)? }\end{array}$ \\
\hline- & - & $\begin{array}{l}\ldots \text { notifica a você sobre as razões de necessidades } \\
\text { de conferências, reuniões, etc. sobre seu filho? }\end{array}$ \\
\hline - & - & $\begin{array}{l}\text {... garante oportunidades para que toda a família } \\
\text { obtenha as informações? }\end{array}$ \\
\hline
\end{tabular}


continuação

\begin{tabular}{|l|l|l|}
\hline $\begin{array}{l}\ldots \text { oferece informações acessíveis sobre outras } \\
\text { preocupações (custos, aconselhamento } \\
\text { genético, compromissos, sexualidade)? }\end{array}$ & $\begin{array}{l}\text {.. oferece informações acessíveis sobre outras } \\
\text { preocupações (custos, aconselhamento } \\
\text { genético, compromissos, sexualidade)? }\end{array}$ & $\begin{array}{l}\ldots \text { ofece informações acessíveis sobre outras } \\
\text { preocupações (custos, aconselhamento genético, } \\
\text { compromissos, sexualidade)? }\end{array}$ \\
\hline
\end{tabular}


Após o consenso final realizado na etapa do brainstorming, a pesquisadora/ tradutora revisou a versão consenso, realizando, ainda, algumas alterações quanto à adequação de vocabulário e aspectos gramaticais (TABELA 4).

Tabela 4 Versão final do protocolo pela pesquisadora.

\section{CONSENSO DOS PERITOS E DA TRADUTORA (PESQUISADORA) NO BRAINSTORMING}

Gostaríamos de entender e avaliar as
experiências dos pais que possuem filho(a) com alguma deficiência. Em especial, gostaríamos de saber as considerações quanto ao atendimento que ele(a) tem recebido no último ano no Centro de Tratamento (Reabilitação).

As questões nesta sessão são referentes ao que os pais, iguais a você, têm a dizer a respeito do serviço oferecido. Pedimos que você aponte a frequência com que um acontecimento ou situação ocorre (ou não) no centro de tratamento (reabilitação). Você responderá cada questão em uma escala do 1 (nunca) ao 7 (Sempre).

O tratamento que você e seu (sua) filho(a) receberam do Centro possibilita o contato com muitos indivíduos. Dessa forma, as questões estão agrupadas de modo a indicar quem são esses contatos, descritos abaixo.

1. PESSOAS: Se refere àqueles indivíduos que trabalham diretamente com você ou seu filho (a). Podem incluir psicólogos, terapeutas, assistentes sociais, médicos, professores, etc.

2. INSTITUIÇÃO: Se refere a toda equipe do centro, envolvida diretamente ou não com seu filho (a). Além das pessoas do centro de tratamento, a equipe pode incluir grupos de apoio, tais como, pessoas que trabalham no escritório, serviços gerais, departamento administrativo, etc.

Abaixo está um exemplo do tipo de pergunta presente no questionário.

Esse exemplo também mostra o que a sua resposta pode significar.

COM QUE FREQUÊNCIA AS PESSOAS QUE ENTREGAM QUESTIONÁRIOS A VOCÊ.

oferecem instruções claras quanto ao preenchimento?

\section{VERSÃO FINAL DA PESQUISADORA}

Gostaríamos de entender e avaliar as experiências dos pais que possuem filho(a) com alguma deficiência. Em especial, gostaríamos de saber as considerações quanto ao atendimento que ele(a) tem recebido no último ano no Centro de Tratamento (Reabilitação).

As questões nesta sessão são referentes ao que os pais, iguais a você, têm a dizer a respeito do serviço oferecido. Pedimos que você aponte a frequência com que um acontecimento ou situação ocorre (ou não) no centro de tratamento (reabilitação). Você responderá a cada questão em uma escala do 1 (nunca) ao 7 (Sempre).

O tratamento que você e seu (sua) filho(a) receberam do Centro possibilita o contato com muitos indivíduos. Dessa forma, as questões estão agrupadas de modo a indicar quem são esses contatos, descritos abaixo.

1. PESSOAS: Se refere àqueles indivíduos que trabalham diretamente com você ou seu filho (a). Podem incluir psicólogos, terapeutas, assistentes sociais, médicos, professores, etc.

2. INSTITUIÇÃO: Se refere a toda equipe do centro, envolvida diretamente ou não com seu filho(a). Além das pessoas do centro de tratamento, a equipe pode incluir grupos de apoio, tais como, pessoas que trabalham no escritório, serviços gerais, departamento administrativo, etc.

Abaixo encontra-se um exemplo do tipo de pergunta presente neste questionário.

Esse exemplo também mostra o que a sua resposta pode significar.

COM QUE FREQUÊNCIA AS PESSOAS QUE ENTREGAM QUESTIONÁRIOS A VOCÊ...

. oferecem instruções claras quanto ao preenchimento? 
Caso circule o número 4 (às vezes) significa que as pessoas que entregam questionário a você fornecem instruções claras sobre o que querem que você faça em parte, mas para o restante, as continuação ram claras.

Caso circule o número 1 (nunca), isso significa que, embora tenha recebido 0 questionário, as instruções não foram claras.

Caso circule o número 0 (não se aplica), isso significa que você nunca recebeu um questionário e, por conseguinte, não pode responder as questões, isto é, esse questionário não se aplica a você ou a sua realidade.

Gostaríamos que você pensasse sobre as experiências vividas no último ano com seu filho no Centro. Estamos interessados em sua opinião e gostaríamos que você completasse o questionário sem conversar com outras pessoas.

Por favor, para cada questão indique a frequência com que cada situação ou evento aconteceu com você, circule apenas um número (de 1 a 7 ) que melhor descreva a sua experiência. Enquanto responde a essas questões, gostaríamos que você pensasse no centro em que seu filho (a) é acompanhado.

Para nossa referência, escreva o nome do centro nesta linha:

Pessoas se referem àqueles indivíduos que trabalham diretamente com você ou seu filho. Esses podem incluir professores, psicólogos, terapeutas, assistentes sociais, médicos, etc.

NO ULTIMO ANO ...

... sugerem planos terapêuticos adaptados as necessidades e ao estilo de vida da sua família?

... explicam completamente as possibilidades de tratamento?

... oferecem a você retorno positivo ou incentivo (por exemplo, por você realizar as atividades terapêuticas domiciliares)?

... explicam os assuntos de forma que seu (sua) filho (a) entenda?

... separam um tempo para estabelecer um vínculo com você e seu filho quando ocorrem mudanças nos serviços prestados?

... conversam com você sobre as expectativas de todos quanto ao que é melhor para a criança?

... verificam se as habilidades da criança são reconhecidas pelos profissionais que atuam com ela e, dessa forma, são realizadas entre os prestadores de serviços e os serviços?

... apresentam opções de tratamento ou serviços para o paciente (como aparelhos, escola, terapia)?
Caso circule o número 4 (às vezes) significa que as pessoas que entregam questionário a você fornecem instruções claras sobre o que querem que você faça, mas em partes, pois para o restante, as instruções não foram claras.

Caso circule o número 1 (nunca), isso significa que, embora tenha recebido o questionário, as instruções não foram claras.

Caso circule o número 0 (não se aplica), isso significa que você nunca recebeu um questionário e, por conseguinte, não pode responder as questões, isto é, esse questionário não se aplica a você ou a sua realidade.

Gostaríamos que você pensasse sobre as experiências vividas no último ano com seu (sua) filho(a) no Centro. Estamos interessados em sua opinião e gostaríamos que você completasse o questionário sem conversar com outras pessoas.

Por favor, para cada questão indique a frequência com que cada situação ou evento aconteceu com você, circule apenas um número (de 1 a 7 ) que melhor descreva a sua experiência. Enquanto responde a essas questões, gostaríamos que você pensasse no centro onde seu (sua) filho (a) recebe acompanhamento.

Para nossa referência, escreva o nome do centro nesta linha:

Pessoas se referem àqueles indivíduos que trabalham diretamente com você ou seu filho. Esses podem incluir professores, psicólogos, terapeutas, assistentes sociais, médicos, etc.

NO ULTIMO ANO ...

... sugerem planos terapêuticos adaptados as necessidades e ao estilo de vida da sua família?

... explicam completamente as possibilidades de tratamento?

... oferecem a você um retorno positivo ou incentivo

(por exemplo, por você realizar as atividades terapêuticas em sua casa)?

... explicam os assuntos de forma que seu (sua) filho (a) entenda?

... reservam um momento para estabelecer um vínculo com você e seu filho quando ocorrem mudanças nos serviços prestados?

conversam com você sobre as expectativas de todos quanto ao que é melhor para a criança?

... verificam se as habilidades do(a) seu (sua) filho(a) são reconhecidas pelos profissionais que atuam com ele(a) e, dessa forma, são efetuadas entre serviços e prestadores de serviços?

... apresentam opções de tratamento ou serviços para seu (sua) filho(a) (como recursos auxiliares, escola, terapia)? 


\begin{tabular}{|c|c|}
\hline $\begin{array}{l}\text {... aceitam você e sua família sem nenhum tipo de } \\
\text { julgamento? }\end{array}$ & $\begin{array}{l}\text {... aceitam você e sua família sem fazer nenhum } \\
\text { tipo de julgamento? }\end{array}$ \\
\hline $\begin{array}{l}\text {... orientam você de modo a ajudá-lo a lidar com } \\
\text { o sistema de saúde? }\end{array}$ & $\begin{array}{l}\text {.. orientam você de modo a ajudá-lo a lidar com o } \\
\text { sistema de saúde? }\end{array}$ \\
\hline
\end{tabular}

continua

continuação

... reconhecem os cuidados necessários ao lidar com uma criança com deficiência?

... confiam em você como um especialista sobre seu filho (a)?

... observam todas necessidades da criança como um todo (mental, emocional, social) além da deficiência física?

... demonstram sensibilidade com os sentimentos da família em ter um filho com deficiência (por exemplo, suas preocupações com a saúde do seu filho ou funções?

... antecipam informações e prestam auxílio antes mesmo de você pedir?

... certificam que você tem oportunidades durante as visitas ao centro para dizer o que é importante para você?

... permitem que você peça informações e como as deseja receber?

... lembram de detalhes pessoais da criança ou da família quando conversam com você?

... explicam as razões para um tratamento ou recursos auxiliares?

... dão continuidade no próximo atendimento a assuntos discutidos previamente?

... asseguram que pelo menos um membro da equipe já tenha trabalhado com você e sua família há um longo período?

... fornecem oportunidades para que você tome decisões sobre o tratamento?

... respondem a suas perguntas de forma que você compreenda tudo?

... explicam o que estão fazendo quando você está acompanhando seu filho na terapia?

... reconhecem que a família tem a palavra final quando fazem decisões sobre o tratamento do filho?

... comunicam sobre os resultados de avaliações?

... fornecem informações escritas sobre 0 desempenho de seu filho na terapia?

... pedem sua opinião quando discutem sobre recursos auxiliares ou serviços?

... proporcionam um ambiente acolhedor ao invés de dar somente informações?

... informam detalhes dos serviços realizados com seu filho, como por exemplo, as razões para indicá-los, os tipos de terapias e duração?

... tratam você como um indivíduo qualquer ao invés de um responsável por uma criança com deficiência?

... reconhecem os cuidados necessários ao lidar com uma criança com deficiência?

... acreditam que você seja um especialista sobre seu filho (a)?

... observam as necessidades do seu(sua) filho(a) como um todo (mental, emocional, social) além da deficiência física?

... demonstram sensibilidade com os sentimentos da família em ter um(a) filho(a) com deficiência (por exemplo, suas preocupações com a saúde do(a) seu (sua) filho(a) ou funções?

... antecipam informações e prestam auxílio antes mesmo de você pedir?

... certificam que você tem oportunidades durante as visitas ao centro para dizer o que é importante para você?

... permitem que você peça informações e como as deseja receber?

... lembram de detalhes pessoais do(a) seu (sua) filho(a) ou da família quando conversam com você?

... explicam as razões para um tratamento ou recursos auxiliares?

... continuam no próximo atendimento-a assuntos discutidos previamente?

... asseguram que pelo menos um membro da equipe já tenha trabalhado com você e sua família por um longo período?

... fornecem oportunidades para que você tome decisões sobre o tratamento?

... respondem a suas perguntas de modo que você compreenda tudo?

... explicam o que estão fazendo quando você está acompanhando seu (sua) filho(a) na terapia?

... reconhecem que a família tem a palavra final quando fazem decisões sobre o tratamento do(a) filho(a)? ... comunicam sobre os resultados de avaliações?

... fornecem informações por escrito sobre o desempenho de seu (sua) filho(a) na terapia?

... pedem sua opinião quando discutem sobre recursos auxiliares ou serviços?

... proporcionam um ambiente acolhedor ao invés de dar somente informações?

... informam detalhes sobre serviços realizados com seu (sua) filho(a), come por exemplo, as razões para indicá-los, os tipos de terapias e duração?

... tratam você como um indivíduo e não apenas como pai ou responsável por uma criança com deficiência?

... estabelecem metas a curto e longo prazo para


seu filho?

... tratam você pelo seu nome sem se referir a você apenas como responsável pelo paciente (por exemplo não se referem a você como "pai" ou "mãe")?

continuação lento juntos para que o mesmo ado?

... asseguram de que você tenha oportunidades para que opine sobre os objetivos do tratamento?

... fazem você se sentir um parceiro no tratamento de seu filho?

... certificam que você está informado antes de quaisquer mudanças nos cuidados do seu filho (por exemplo, terapeutas, programas e equipamentos)?

... auxiliam você a se sentir competente enquanto responsável pela criança?

... fornecem informações escritas do progresso do seu filho?

... se preocupam com as necessidades conforme seu filho cresce?

têm tempo suficiente para conversar com você de modo que não se sinta apressado?

... tratam você e sua família como pessoas e não apenas como uma "doença" (por exemplo, não se referem a você como um diagnóstico, tal como "esse é deficiência auditiva" ou outra?

... escutam o que você tem a dizer sobre as necessidades do seu filho por recursos auxiliares ou serviços?

... estão disponíveis para você como um suporte (por ex. apoio emocional, proteção, informação)?

... fornecem informações sobre sua criança que sejam consistentes de pessoa a pessoa?

... sugerem terapias que se adaptam as necessidades e ao estilo de vida da sua família?

Centro se refere à equipe envolvida diretamente ou não com seu filho. Além dos profissionais dos serviços de saúde, podem incluir-se também as pessoas da equipe de suporte, tais como equipe administrativa, de coordenação, de limpeza, etc.

\section{NO ULTIMO ANO ...}

Com que frequência o centro onde você recebe os serviços...

... disponibiliza informações a você em vários formatos, tais como folheto, kit, vídeo, etc.?

... possui uma equipe de suporte prestativa $e$ educada com você e sua família?

... fornece informações sobre os tipos de serviços oferecidos no Centro ou em sua comunidade?

... promove reuniões de pais e responsáveis para compartilhar experiências social, informativa e profissional?

... promove oportunidades para encontros com especialistas e pais sobre assuntos do interesse?

... fornece suporte para enfrentar os impactos da deficiência na infância (como proteção de seus seu (sua) filho(a)?

... se dirigem a você pelo nome e não simplesmente como o responsável pelo paciente (por exemplo, não se referem a você como "pai" ou "mãe")?

... planejam o tratamento juntos para que o mesmo objetivo seja trabalhado?

... asseguram de que você tem oportu

que opine sobre os objetivos do tratam continua

... fazem você se sentir um parceiro no tratamento de seu (sua) filho(a)?

... certificam que você está informado antes de quaisquer mudanças nos cuidados do seu (sua) filho(a) (por exemplo, terapeutas, programas e recursos auxiliares)?

... auxiliam você a se sentir competente enquanto responsável pela criança?

... fornecem informações por escrito do progresso do(a) seu (sua) filho(a)?

... se preocupam com as necessidades de seu (sua) filho(a) conforme ele(a) cresce?

... disponibiliza tempo suficiente para conversar com você de modo que não se sinta apressado?

... tratam você e sua família como pessoas e não apenas como uma "doença" (por exemplo, não se referem a você como um diagnóstico, tal como "esse é o de deficiência auditiva"?

... escutam o que você tem a dizer sobre as necessidades de seu (sua) filho(a) por recursos auxiliares,-ou-serviços, etc.?

... estão disponíveis para você como um suporte (por exemplo, apoio emocional, proteção, informação)?

... fornecem informações sobre seu (sua) filho(a) que sejam consistentes de pessoa a pessoa?

... sugerem terapias que se adaptam as necessidades e ao estilo de vida da sua família? Centro se refere à equipe envolvida diretamente ou não com seu (sua) filho(a). Além dos profissionais dos-servicos-de da saúde, podem incluir-se, também, as pessoas da equipe de suporte, tais como equipe administrativa, de coordenação, de limpeza, etc.

NO ULTIMO ANO ...

Com que frequência o centro onde você recebe os serviços...

... disponibiliza informações a você em vários formatos, tais como folheto, kit, vídeo, etc.?

... possui uma equipe de suporte educada e prestativa com você e sua família?

... fornece informações sobre os tipos de serviços oferecidos no Centro ou em sua comunidade?

... promove reuniões de pais e/ou responsáveis para compartilhar experiências social, informativa e profissional?

... promove oportunidades para encontros com especialistas e pais sobre assuntos do interesse?

... fornece suporte para enfrentar os impactos da deficiência na infância (como proteção de seus 


\begin{tabular}{|l|l|l|}
\hline $\begin{array}{l}\text { interesses ou informando sobre programas } \\
\text { assistenciais)? }\end{array}$ & $\begin{array}{l}\text { interesses ou informações sobre programas } \\
\text { assistenciais)? }\end{array}$ \\
\hline $\begin{array}{l}\ldots \text { notifica a você sobre as razões de necessidades } \\
\text { de conferências, reuniões, etc. sobre seu filho? }\end{array}$ & $\begin{array}{l}\ldots \text { comunica você sobre as razões de } \\
\text { conferências, reuniões, etc. sobre seu (sua) } \\
\text { filho(a)? }\end{array}$ \\
\hline $\begin{array}{l}\ldots \text { possui informações disponíveis sobre a a a disponibiliza informações disponíveis sobre a } \\
\text { deficiência da criança (por exemplo, causas, } \\
\text { avanços, perspectivas futuras)? }\end{array}$ & $\begin{array}{l}\ldots \text { deficiência da criança (por exemplo, causas, } \\
\text { avanços, perspectivas futuras)? }\end{array}$ \\
\hline
\end{tabular}

... fornece orientações em como obter informações ou o contato com outros responsáveis (por exemplo, um recurso de banco de dados para os pais do Centro)?

... garante oportunidades para que toda a família obtenha as informações?

... oferece informações acessíveis sobre outras preocupações (custos, aconselhamento genético, compromissos, sexualidade)?

... fornece orientações em como obter informações ou o contato com outros responsáveis (por exemplo, um recurso de banco de dados para os pais do Centro)?

... garante oportunidades para que toda a família obtenha as informações?

... possui informações gerais disponíveis sobre outras preocupações (custos, aconselhamento genético, compromissos, sexualidade)?

\title{
5.2 Análise Comparativa
}

\section{Os resultados da análise comparativa de acordo com os procedimentos}

\author{
técnicos sugeridos por Barbosa (2004) demonstram as opções do tradutor durante o \\ processo de tradução do protocolo.
}

Tabela 5 Comparativo entre o original e a tradução final.

\begin{tabular}{|c|c|}
\hline ORIGINAL - Inglês & VERSAO FINAL- Port-BR \\
\hline $\begin{array}{l}\text { We would like to understand and measure } \\
\text { the experiences of parents who have a child with } \\
\text { disability. In particular we wish to know about your } \\
\text { perceptions of the care you have been receiving over } \\
\text { the past year from your child's Treatment } \\
\text { (Reabilitation) Centre. } \\
\text { The questions in this section are based on } \\
\text { what parents, like yourself, have told us about the } \\
\text { way care is sometimes offered. We would like you to } \\
\text { indicate how much the event or situation happens (or } \\
\text { doesn't happen) to you at your treatment centre. You } \\
\text { are asked to answer each question on a scale from } 7 \\
\text { (To a Great Extent) do } 1 \text { (Never). } \\
\text { The care that you and your child received } \\
\text { from the Centre may bring you into contact with } \\
\text { many individuals. The questions on this form are } \\
\text { grouped by who these contacts are, as described } \\
\text { below. }\end{array}$ & $\begin{array}{l}\text { Gostaríamos de entender e avaliar as } \\
\text { experiências dos pais que possuem filho(a) com } \\
\text { alguma deficiência. Em especial, gostaríamos de saber } \\
\text { as considerações quanto ao atendimento que ele(a) } \\
\text { tem recebido no último ano no Centro de Tratamento } \\
\text { (Reabilitação). } \\
\text { As questões nesta sessão são referentes ao } \\
\text { que os pais, iguais a você, têm a dizer a respeito do } \\
\text { serviço oferecido. Pedimos que você aponte a } \\
\text { frequência com que um acontecimento ou situação } \\
\text { ocorre (ou não) no centro de tratamento (reabilitação). } \\
\text { Você responderá a cada questão em uma escala do } 1 \\
\text { (nunca) ao } 7 \text { (Sempre). } \\
\text { O tratamento que você e seu (sua) filho(a) } \\
\text { receberam do Centro possibilita o contato com muitos } \\
\text { indivíduos. Dessa forma, as questões estão agrupadas } \\
\text { de modo a indicar quem são esses contatos, descritos } \\
\text { abaixo. }\end{array}$ \\
\hline $\begin{array}{l}\text { 1. PEOPLE: refers to those individuals who work } \\
\text { directly with you or your child. These may include } \\
\text { psycologists, therapists, social works, doctors, } \\
\text { teachers, etc. } \\
\text { 2. CENTRE: refers to all staff from the centre, } \\
\text { whether involved directly with your child or not. In } \\
\text { addition to health care people they may include }\end{array}$ & $\begin{array}{l}\text { 1. PESSOAS: Se refere àqueles indivíduos que } \\
\text { trabalham diretamente com você ou seu filho (a). } \\
\text { Podem incluir psicólogos, terapeutas, assistentes } \\
\text { sociais, médicos, professores, etc. } \\
\text { 2. INSTITUIÇÃO: Se refere a toda equipe do centro, } \\
\text { envolvida diretamente ou não com seu filho(a). Além } \\
\text { das pessoas do centro de tratamento, a equipe pode }\end{array}$ \\
\hline
\end{tabular}


continua

support staff such as office staff, housekeepers, administrative personnel, etc.

The following is an example of the kinds of questions you will be asked.

This example also shows what your answer could continuação

\begin{tabular}{|l|}
\hline $\begin{array}{l}\text { TO WHAT EXTENT DO THE PEOPLE WHO } \\
\text { GIVE TOU QUESTIONARIES }\end{array}$ \\
... provide you clear instructions on how to \\
complete them?
\end{tabular}

If you circled $n^{\circ} 4$ (Sometimes), it means that the people who give you questionnaires are clear in what they want you to some of the time, and some of the time the instructions are not clear.

If you circled $\mathrm{n}^{0} \mathbf{1}$ (Never), it means that although you have received questionnaires, the instructions are never clear.

If you circled no0 (Not Applicable), it means that you have never received a questionnaire and so you cannot answer the question. It does not apply to you.

We would like you to think about your experiences over the past year child's Centre. We are interested in your personal thoughts and would appreciate your completing this questionnaire on your own without discussing it with anyone.

For each question, please indicate how much the event or situation happens to you by circling one number (from 1 to 7 ) that you feel best fits your experience. When answering these questions, we would like to you to think about the Centre from which you first found about this study. incluir grupos de apoio, tais como, pessoas que trabalham no escritório, serviços gerais, departamento administrativo, etc.

Abaixo encontra-se um exemplo do tipo de pergunta presente neste questionário.

Esse exemplo também mostra o que a sua resposta pode significar.

\section{COM QUE FREQUÊNCIA AS PESSOAS QUE ENTREGAM QUESTIONÁRIOS A VOCÊ...}

... oferecem instruções claras quanto ao preenchimento?
Caso circule o número 4 (às vezes) significa que as pessoas que entregam questionário a você fornecem instruções claras sobre o que querem que você faça, mas em partes, pois para o restante, as instruções não foram claras.

Caso circule o número 1 (nunca), significa que, embora tenha recebido o questionário, as instruções não foram claras.

Caso circule o número 0 (não se aplica), isso significa que você nunca recebeu um questionário e, por conseguinte, não pode responder as questões, isto é, esse questionário não se aplica a você ou a sua realidade.

Gostaríamos que você pensasse sobre as experiências vividas no último ano com seu (sua) filho(a) no Centro. Estamos interessados em sua opinião e gostaríamos que você completasse o questionário sem conversar com outras pessoas.

Por favor, para cada questão indique a frequência com que cada situação ou evento aconteceu com você, circule apenas um número (de 1 a 7 ) que melhor descreva a sua experiência. Enquanto responde a essas questões, gostaríamos que você pensasse no centro onde seu (sua) filho (a) recebe acompanhamento.

Para nossa referência, escreva o nome do centro nesta linha:

Pessoas se referem àqueles indivíduos que trabalham diretamente com você ou seu filho. Esses podem incluir professores, psicólogos, terapeutas, assistentes sociais, médicos, etc.
For easy reference, we have written the name of that Centre on this line:

People refers to those individuals who work directly with you or your child. These may include teachers, psychologists, therapists, social workers, doctors, etc.

IN THE PAST YEAR, TO WHAT EXTENT DO THE

NO ÚLTIMO ANO, COM QUAL FREQUÊNCIA AS 


\begin{tabular}{|c|c|c|}
\hline \multicolumn{2}{|c|}{ PEOPLE WHO WORK WITH YOUR CHILD... } & PESSOAS TRABALHARAM COM SEU FILHO(A) \\
\hline 1 & $\begin{array}{l}\text {... suggest therapy plans that fit with your } \\
\text { family's needs and lifestyle? }\end{array}$ & $\begin{array}{l}\ldots \text { sugerem planos terapêuticos adaptados as } \\
\text { necessidades e ao estilo de vida da sua família? }\end{array}$ \\
\hline 2 & ... fully explain treatment choices to you? & $\begin{array}{l}\text {... explicam completamente as possibilidades de } \\
\text { tratamento? }\end{array}$ \\
\hline 3 & $\begin{array}{l}\text {... offer you positive feedback or } \\
\text { encouragement (e.g., in carrying out a home } \\
\text { program)? }\end{array}$ & $\begin{array}{l}\text {... oferecem a você um retorno positivo ou incentivo } \\
\text { (por exemplo, por você realizar as atividades } \\
\text { terapêuticas em sua casa)? }\end{array}$ \\
\hline
\end{tabular}

continuação

continua

\begin{tabular}{|c|c|c|}
\hline 4 & $\begin{array}{l}\text {... explain things to your child in a way that } \\
\text { your child understands? }\end{array}$ & $\begin{array}{l}\text {... explicam os assuntos de forma que seu (sua) filho } \\
\text { (a) entenda? }\end{array}$ \\
\hline 5 & $\begin{array}{l}\text {... take the time to establish rapport with you } \\
\text { or your child when changes occur in your } \\
\text { services? }\end{array}$ & $\begin{array}{l}\text {... reservam um momento para estabelecer um vínculo } \\
\text { com você e seu filho quando ocorrem mudanças nos } \\
\text { serviços prestados? }\end{array}$ \\
\hline 6 & $\begin{array}{l}\text {... discuss with you everyone's expectations } \\
\text { for your child, so that all agree on what is } \\
\text { best? }\end{array}$ & $\begin{array}{l}\text {... conversam com você sobre as expectativas de } \\
\text { todos quanto ao que é melhor para a criança? }\end{array}$ \\
\hline 7 & $\begin{array}{l}\text {... make sure that your child's skills are known } \\
\text { to all persons working with your child, so the } \\
\text { skills are carried across services and service } \\
\text { providers? }\end{array}$ & $\begin{array}{l}\text {... verificam se as habilidades do(a) seu (sua) filho(a) } \\
\text { são reconhecidas pelos profissionais que atuam com } \\
\text { ele(a) e, dessa forma, são efetuadas entre serviços } \\
\text { prestadores de serviços? }\end{array}$ \\
\hline 8 & $\begin{array}{l}\text {... tell you about options for treatment or } \\
\text { services for your child (e.g., equipment, } \\
\text { school, therapy)? }\end{array}$ & $\begin{array}{l}\text {... apresentam opções de tratamento ou serviços para } \\
\text { seu (sua) filho(a) (como recursos auxiliares, escola, } \\
\text { terapia)? }\end{array}$ \\
\hline 9 & $\begin{array}{l}\ldots \text { accept you and your family in a } \\
\text { nonjudgmental way? }\end{array}$ & $\begin{array}{l}\text {... aceitam você e sua família sem fazer nenhum tipo } \\
\text { de julgamento? }\end{array}$ \\
\hline 10 & $\begin{array}{l}\text {... provide ideas to help you work with the } \\
\text { health care "system"? }\end{array}$ & $\begin{array}{l}\text {... orientam você de modo a ajudá-lo a lidar com o } \\
\text { sistema de saúde? }\end{array}$ \\
\hline 11 & $\begin{array}{l}\text {... recognize the demands of caring for a } \\
\text { child with special needs? }\end{array}$ & $\begin{array}{l}\text {... reconhecem os cuidados necessários ao lidar com } \\
\text { uma criança com deficiência? }\end{array}$ \\
\hline 12 & ... trust you as the "expert" on your child? & $\begin{array}{l}\text {... acreditam que você seja um especialista sobre seu } \\
\text { filho (a)? }\end{array}$ \\
\hline 13 & $\begin{array}{l}\text {... look at the needs of your "whole" child (e.g., } \\
\text { at mental, emotional, and social needs) } \\
\text { instead of just at physical needs? }\end{array}$ & $\begin{array}{l}\text {... observam as necessidades do seu(sua) filho(a) } \\
\text { como um todo (mental, emocional, social) além da } \\
\text { deficiência física? }\end{array}$ \\
\hline 14 & $\begin{array}{l}\text {... show sensitivity to your family's feelings } \\
\text { about having a child with special needs (e.g., } \\
\text { your worries about your child's health or } \\
\text { function)? }\end{array}$ & $\begin{array}{l}\text {... demonstram sensibilidade com os sentimentos da } \\
\text { família em ter um(a) filho(a) com deficiência (por } \\
\text { exemplo, suas preocupações com a saúde do(a) seu } \\
\text { (sua) filho(a) ou funcões? }\end{array}$ \\
\hline 15 & $\begin{array}{l}\text {... anticipate your concerns by offering } \\
\text { information even before you ask? }\end{array}$ & $\begin{array}{l}\text {... antecipam informações e prestam auxílio antes } \\
\text { mesmo de você pedir? }\end{array}$ \\
\hline 16 & $\begin{array}{l}\text {... make sure you have a chance during visits } \\
\text { to the centre to say what is important to you? }\end{array}$ & $\begin{array}{l}\text {... certificam que você tem oportunidades durante as } \\
\text { visitas ao centro para dizer o que é importante para } \\
\text { você? }\end{array}$ \\
\hline 17 & $\begin{array}{l}\text {... let you choose when to receive information } \\
\text { and the type of information you want? }\end{array}$ & $\begin{array}{l}\text {... permitem que você peça informações e como as } \\
\text { deseja receber? }\end{array}$ \\
\hline 18 & $\begin{array}{l}\text {... remember personal details about your child } \\
\text { or family when speaking with you? }\end{array}$ & $\begin{array}{l}\text {... lembram de detalhes pessoais do(a) seu (sua) } \\
\text { filho(a) ou da família quando conversam com você? }\end{array}$ \\
\hline 19 & $\begin{array}{l}\text {... tell you about the reasons for treatment or } \\
\text { equipment? }\end{array}$ & $\begin{array}{l}\text {... explicam as razões para um tratamento ou recursos } \\
\text { auxiliares? }\end{array}$ \\
\hline 20 & $\begin{array}{l}\ldots \text { follow up at the next appointment on any } \\
\text { concerns you discussed at the previous one? }\end{array}$ & $\begin{array}{l}\text { c.. continuam no próximo atendimento assuntos } \\
\text { discutidos previamente? }\end{array}$ \\
\hline 21 & $\begin{array}{l}\text {... make sure that at least one team member } \\
\text { is someone who works with you and your } \\
\text { family over a long period of time? }\end{array}$ & $\begin{array}{l}\text {.. asseguram que pelo menos um membro da equipe } \\
\text { já tenha trabalhado com você e sua família por um } \\
\text { longo período? }\end{array}$ \\
\hline 22 & $\begin{array}{l}\text {... provide opportunities for you to make } \\
\text { decisions about treatment? }\end{array}$ & $\begin{array}{l}\text {... fornecem oportunidades para que você tome } \\
\text { decisões sobre o tratamento? }\end{array}$ \\
\hline 23 & ... answer your questions completely? & ... respondem a suas perguntas de modo que você \\
\hline
\end{tabular}




\begin{tabular}{|c|c|c|}
\hline & & compreenda tudo? \\
\hline 24 & $\begin{array}{l}\text {... explain what they are doing when you are } \\
\text { watching your child in therapy? }\end{array}$ & $\begin{array}{l}\text {... explicam o que estão fazendo quando você está } \\
\text { acompanhando seu (sua) filho(a) na terapia? }\end{array}$ \\
\hline 25 & $\begin{array}{l}\text {... recognize that your family has the final say } \\
\text { when making decisions about your child's } \\
\text { treatment? }\end{array}$ & $\begin{array}{l}\text {... reconhecem que a família tem a palavra final } \\
\text { quando fazem decisões sobre o tratamento do(a) } \\
\text { filho(a)? }\end{array}$ \\
\hline \multicolumn{2}{|c|}{$\begin{array}{ll}\text { continuação } & \begin{array}{l}\text { about the results from } \\
\text { its? }\end{array}\end{array}$} & ... comunicam sobre os resultados de avaliações? \\
\hline 27 & $\begin{array}{l}\text {... provide you with written information about } \\
\text { what your child is doing in therapy? }\end{array}$ & $\begin{array}{l}\ldots \text { fornecem informações por escritı } \\
\text { desempenho de seu (sua) filho(a) na terap continua }\end{array}$ \\
\hline 28 & $\begin{array}{l}\text {... consult with you when discussing } \\
\text { equipment or services? }\end{array}$ & $\begin{array}{l}\text {... pedem sua opinião quando discutem sobre recursos } \\
\text { auxiliares ou serviços? }\end{array}$ \\
\hline 29 & $\begin{array}{l}\text {... provide a caring atmosphere rather than } \\
\text { just give you information? }\end{array}$ & $\begin{array}{l}\ldots \text { proporcionam um ambiente acolhedor ao invés de } \\
\text { dar somente informações? }\end{array}$ \\
\hline 30 & $\begin{array}{l}\text {... tell you details about your child's services, } \\
\text { such as the reasons for them, the type of } \\
\text { therapies and the length of time? }\end{array}$ & $\begin{array}{l}\text {... informam detalhes sobre serviços realizados com } \\
\text { seu (sua) filho(a), por exemplo, as razões para indicá- } \\
\text { los, os tipos de terapias e duração? }\end{array}$ \\
\hline 31 & $\begin{array}{l}\text {... treat you as an individual rather than as a } \\
\text { "typical" parent of a child with a disability? }\end{array}$ & $\begin{array}{l}\text {... tratam você como um indivíduo e não apenas como } \\
\text { pai ou responsável por uma criança com deficiência? }\end{array}$ \\
\hline 32 & $\begin{array}{l}\text {... develop both short-term and long-term } \\
\text { goals for your child? }\end{array}$ & $\begin{array}{l}\text {... estabelecem metas a curto e longo prazo para seu } \\
\text { (sua) filho(a)? }\end{array}$ \\
\hline 33 & $\begin{array}{l}\text {... treat you as an equal rather than just as the } \\
\text { parent of a patient (e.g., by not referring to you } \\
\text { as "Mom" or "Dad")? }\end{array}$ & $\begin{array}{l}\text {... se dirigem a você pelo nome e não simplesmente } \\
\text { como o responsável pelo paciente (por exemplo, não } \\
\text { se referem a você como "pai" ou "mãe")? }\end{array}$ \\
\hline 34 & $\begin{array}{l}\text {... plan together so they are all working in the } \\
\text { same direction? }\end{array}$ & $\begin{array}{l}\text {... planejam o tratamento juntos para que o mesmo } \\
\text { objetivo seja trabalhado? }\end{array}$ \\
\hline 35 & $\begin{array}{l}\text {... make sure you have opportunities to } \\
\text { explain what you think are important treatment } \\
\text { goals? }\end{array}$ & $\begin{array}{l}\text {... asseguram de que você tem oportunidades para que } \\
\text { opine sobre os objetivos do tratamento? }\end{array}$ \\
\hline 36 & $\begin{array}{l}\text {... make you feel like a partner in your child's } \\
\text { care? }\end{array}$ & $\begin{array}{l}\text {... fazem você se sentir um parceiro no tratamento de } \\
\text { seu (sua) filho(a)? }\end{array}$ \\
\hline 37 & $\begin{array}{l}\text {... make sure you are informed ahead of time } \\
\text { about any changes in your child's care (e.g., } \\
\text { therapists, programs, equipment)? }\end{array}$ & $\begin{array}{l}\text {... certificam que você está informado antes de } \\
\text { quaisquer mudanças nos cuidados do seu (sua) } \\
\text { filho(a) (por exemplo, terapeutas, programas e } \\
\text { recursos auxiliares)? }\end{array}$ \\
\hline 38 & ... help you to feel competent as a parent? & $\begin{array}{l}\text {... auxiliam você a se sentir competente enquanto } \\
\text { responsável pela criança? }\end{array}$ \\
\hline 39 & $\begin{array}{l}\text {... provide you with written information about } \\
\text { your child's progress? }\end{array}$ & $\begin{array}{l}\ldots \text { fornecem informações por escrito do progresso } \\
\text { do(a) seu (sua) filho(a)? }\end{array}$ \\
\hline 40 & $\begin{array}{l}\text {... seem aware of your child's changing needs } \\
\text { as he/she grows? }\end{array}$ & $\begin{array}{l}\text {... se preocupam com as necessidades de seu (sua) } \\
\text { filho(a) conforme ele(a) cresce? }\end{array}$ \\
\hline 41 & $\begin{array}{l}\text {... provide enough time to talk so you don't } \\
\text { feel rushed? }\end{array}$ & $\begin{array}{l}\text {... disponibiliza tempo suficiente para conversar com } \\
\text { você de modo que não se sinta apressado? }\end{array}$ \\
\hline 42 & $\begin{array}{l}\text {... treat you and your family as people rather } \\
\text { than as a "case" (e.g., by not referring to you } \\
\text { by diagnosis, such as "the spastic diplegic")? }\end{array}$ & $\begin{array}{l}\text {... tratam você e sua família como pessoas e não como } \\
\text { uma "doença" (por exemplo, não se referem a você } \\
\text { como um diagnóstico, tal como "o de deficiência } \\
\text { auditiva"? }\end{array}$ \\
\hline 43 & $\begin{array}{l}\text {... listen to what you have to say about your } \\
\text { child's needs for equipment, services, etc.? }\end{array}$ & $\begin{array}{l}\text { escutam o que você tem a dizer sobre as } \\
\text { necessidades de seu (sua) filho(a) por recursos } \\
\text { auxiliares, serviços, etc.? }\end{array}$ \\
\hline 44 & $\begin{array}{l}\text {... make themselves available to you as a } \\
\text { resource (e.g., emotional support, advocacy, } \\
\text { information)? }\end{array}$ & $\begin{array}{l}\text {... estão disponíveis para você como um suporte (por } \\
\text { exemplo, apoio emocional, proteção, informação)? }\end{array}$ \\
\hline \multirow[t]{2}{*}{45} & $\begin{array}{l}\text {... give you information about your child that is } \\
\text { consistent from person to person? }\end{array}$ & $\begin{array}{l}\text {... fornecem informações sobre seu (sua) filho(a) que } \\
\text { sejam consistentes de pessoa a pessoa? }\end{array}$ \\
\hline & $\begin{array}{l}\text { Centre refers to all staff from the centre, } \\
\text { whether involved directly with your child or not. } \\
\text { In addition to health care professionals, the } \\
\text { people may include support staff such as }\end{array}$ & $\begin{array}{l}\text { Centro se refere à equipe envolvida diretamente ou } \\
\text { não com seu (sua) filho(a). Além dos profissionais da } \\
\text { saúde, podem incluir-se, também, pessoas da equipe } \\
\text { de suporte, tais como administrativa, de coordenação, }\end{array}$ \\
\hline
\end{tabular}




\begin{tabular}{|l|l|l|}
\hline & $\begin{array}{l}\text { office staff, housekeepers, administrative } \\
\text { personnel, etc. }\end{array}$ & \multicolumn{1}{c|}{ de limpeza, etc. } \\
\hline & $\begin{array}{l}\text { In the past year } \\
\text { To what extent does the centre where you } \\
\text { receive services... }\end{array}$ & $\begin{array}{l}\text { No último ano } \\
\text { Com que frequência o centro onde você recebe os } \\
\text { serviços... }\end{array}$ \\
\hline 46 & $\begin{array}{l}\ldots \text { have information available to you in various } \\
\text { forms, such as a booklet, kit, video, etc.? }\end{array}$ & $\begin{array}{l}\ldots \text { disponibiliza informações a você em vários formatos, } \\
\text { tais como folheto, kit, vídeo, etc.? }\end{array}$ \\
\hline
\end{tabular}

continuação

\begin{tabular}{|c|c|c|}
\hline 47 & $\begin{array}{l}\text {... have support staff that are polite and } \\
\text { courteous to you and your family? }\end{array}$ & $\begin{array}{l}\text {... possui uma equipe de suporte educada e prestativa } \\
\text { com você e sua família? }\end{array}$ \\
\hline 48 & $\begin{array}{l}\text {... give you information about the types of } \\
\text { services offered at the Centre or in your } \\
\text { community? }\end{array}$ & $\begin{array}{l}\ldots \text { fornece informações sobre os tipos de serviços } \\
\text { oferecidos no Centro ou em sua comunidade? }\end{array}$ \\
\hline 49 & $\begin{array}{l}\text {... promote family-to-family gatherings for } \\
\text { social, informational or shared experiences? }\end{array}$ & $\begin{array}{l}\text {... promove reuniões de pais e/ou responsáveis para } \\
\text { compartilhar experiências social, informativa e } \\
\text { profissional? }\end{array}$ \\
\hline 50 & $\begin{array}{l}\text {... provide opportunities for special guests to } \\
\text { speak to parents on topics of interest? }\end{array}$ & $\begin{array}{l}\text {... promove oportunidades para encontros com } \\
\text { especialistas e pais sobre assuntos do interesse? }\end{array}$ \\
\hline 51 & $\begin{array}{l}\text {... provide support to help cope with the } \\
\text { impact of childhood disability (e.g., by } \\
\text { advocating on your behalf or informing you of } \\
\text { assistance programs)? }\end{array}$ & $\begin{array}{l}\text {... fornece suporte para enfrentar os impactos da } \\
\text { deficiência na infância (como proteção de seus } \\
\text { interesses ou informações sobre programas } \\
\text { assistenciais)? }\end{array}$ \\
\hline 52 & $\begin{array}{l}\text {... notify you about the reasons for upcoming } \\
\text { case conferences, meetings, etc. about your } \\
\text { child? }\end{array}$ & $\begin{array}{l}\text {... comunica você sobre as razões de conferências, } \\
\text { reuniões, etc. sobre seu (sua) filho(a)? }\end{array}$ \\
\hline 53 & $\begin{array}{l}\text {... have information available about your } \\
\text { child's disability (e.g., its causes, how it } \\
\text { progresses, future outlook)? }\end{array}$ & $\begin{array}{l}\text {... disponibiliza informações sobre a deficiência da } \\
\text { criança (por exemplo, causas, avanços, perspectivas } \\
\text { futuras)? }\end{array}$ \\
\hline 54 & $\begin{array}{l}\text {... provide advice on how to get information or } \\
\text { to contact other parents (e.g., Centre's parent } \\
\text { resource library)? }\end{array}$ & $\begin{array}{l}\text {... fornece orientações em como obter informações ou } \\
\text { o contato com outros responsáveis (por exemplo, um } \\
\text { recurso de banco de dados para os pais do Centro)? }\end{array}$ \\
\hline 55 & $\begin{array}{l}\text {... provide opportunities for the entire family to } \\
\text { obtain information? }\end{array}$ & $\begin{array}{l}\text {... garante oportunidades para que toda a família } \\
\text { obtenha informações? }\end{array}$ \\
\hline 56 & $\begin{array}{l}\text {... have general information available about } \\
\text { different concerns (e.g., financial costs or } \\
\text { assistance, genetic counselling, dating and } \\
\text { sexuality)? }\end{array}$ & $\begin{array}{l}\text {... possui informações gerais disponíveis sobre outras } \\
\text { preocupações (custos, aconselhamento genético, } \\
\text { compromissos, sexualidade)? }\end{array}$ \\
\hline
\end{tabular}

Por meio dos dados obtidos da comparação, foi possível observar que o texto traduzido manteve-se equivalente ao original, em especial por ter sido encontrado somente um procedimento relacionado à adaptação (2\%), isto é, a "recriação, na tradução, de uma situação do texto original que não existe na língua da tradução" (BARBOSA, 1990, p. 76). O procedimento de adaptação ocorreu na questão 42 na qual o termo "the spastic diplegic" recebeu a adaptação para o português "esse é o de deficiência auditiva". Portanto, optou-se pela adaptação do termo em virtude do direcionamento do questionário para a aplicação na área da Fonoaudiologia. Por isso, na etapa do brainstorming, chegou-se ao consenso de que a adaptação do termo contribuiria para a compreensão dos pais e/ou responsáveis pela criança em tratamento. 
Outro aspecto observado em relação a análise comparativa foi a porcentagem do processo de tradução literal (47\%). Aubert (1994) comenta que esse processo é o mais utilizado em virtude de a tradução manter os significados sem alteração semântica e mais fiel ao texto original, como pode ser observado na questão 55:

[...] provide opportunities for the entire family to obtain information? [...] garante oportunidades para que toda a família obtenha informações?

A tradução literal também pode ser exemplificada de acordo com a questão 18:

[...] remember personal details about your child or family when speaking with you?

[...] lembram de detalhes pessoais da criança ou da família quando conversam com você?

A compensação obteve $7 \%$ de utilização enquanto procedimento adotado. Esse procedimento deve-se a um termo compensar outro para a inteligibilidade na língua traduzida, isto é, quando um léxico não é suficiente para a compreensão a possibilidade do acréscimo de outro para a melhor compreensão. De acordo com Barbosa (1998), a compensação pode ter aspectos da tradução literária e, também, mudanças de ordem das palavras.

\section{[...] recognize the demands of caring for a child with special needs? \\ [...] reconhecem os cuidados necessários ao lidar com uma criança com deficiência?}

A transposição representou $10 \%$ dos procedimentos utilizados. De acordo com Barbosa (2004), esse procedimento consiste na mudança de categoria gramatical ao traduzir um termo. Dessa forma, na primeira pergunta tem-se:

\section{[...] suggest therapy plans that fit with [...] - pronome, verbo, preposição}

A opção ao traduzir foi mudar a categoria gramatical acima por um adjetivo que contemplasse o mesmo significado. 
Pode-se observar o mesmo procedimento na questão 23:

\section{[...] ... answer your questions completely? - advérbio}

[...] respondem a suas perguntas de modo que você compreenda tudo? adjunto adverbial

Para Aubert (1998), a transposição sempre ocorre quando se realiza "rearranjos morfossintáticos". Dessa forma, optou-se por essa mudança em virtude da pergunta tornar-se inteligível ao leitor.

Outro elemento do procedimento técnico utilizado foi a modulação (12\%). De acordo com Barbosa (2004), esse recurso é utilizado quando consiste em reproduzir a mensagem da língua original sob um ponto de vista diverso. A recorrência à modulação deve-se à necessidade do texto científico exigir o uso de determinadas técnicas, em especial palavras em comum para o público do qual será aplicado $o$ instrumento.

[...] discuss with you everyone's expectations for your child, so that all agree on what is best?

[...] conversam com você sobre as expectativas de todos quanto ao que é melhor para a criança? (QUESTÃO 05)

A omissão e explicitação foram procedimentos também recorrentes aplicados na tradução, com 10\%. A omissão é mais frequente na língua portuguesa, em especial aos pronomes pessoais do caso reto, pois a conjugação verbal permite que a pessoa seja omitida. Portanto, ela foi utilizada na questão 08 :

[...] tell you about options for treatment or services for your child (e.g., equipment, school, therapy)?

[...] apresentam opções de tratamento ou serviços para seu (sua) filho (a) (como aparelhos, escola, terapia)?

Já o exemplo de explicitação pode ser notado na questão 03, por meio da inserção de informações novas para melhor entendimento do público:

[...] offer you positive feedback or encouragement (e.g., in carrying out a home program)?

[...] oferecem a você um retorno positivo ou incentivo (por exemplo, por você realizar as atividades terapêuticas em sua casa)? 
A reconstrução de períodos (5\%) e equivalência (5\%) foram procedimentos que também foram utilizados, porém com menor frequência que os citados anteriormente. A reconstrução de períodos, de acordo com Barbosa (2004), consiste em redividir ou reagrupar períodos de orações do original para a língua traduzida, em especial com orações mais complexas. Esse procedimento foi utilizado na questão 30:

[...] tell you details about your child's services, such as the reasons for them, the type of therapies and the length of time?

[...] informam detalhes sobre serviços realizados com seu (sua) filho(a), por exemplo, as razões para indicá-los, os tipos de terapias e duração?

Já no processo de equivalência, ocorre a tradução de um termo que não traduz literalmente $\mathrm{o}$ da língua original, mas que the é equivalente funcional (BARBOSA, 2004; AUBERT, 1998).

[...] To what extent do the people who work with your child...

[...] Com que frequência as pessoas que trabalharam com seu filho(a)

O procedimento de transferência foi pouco utilizado (2\%) no estudo, juntamente com a explicação (2\%). A transferência consiste na utilização de termos da língua original para a língua traduzida. Essa técnica pode ser classificada como: estrangeirismo, estrangeirismo transliterado, estrangeirismo aclimatado e estrangeirismo explicado (BARBOSA, 2004). Neste estudo, foi utilizado o estrangeirismo, de acordo com o explicitado na questão 46:

[...] have information available to you in various forms, such as a booklet, kit, video, etc.?

[...] disponibiliza informações a você em vários formatos, tais como folheto, kit, vídeo, etc.?

Sobre a explicação (2\%), a questão 03 elucida o uso desse procedimento:

[...] offer you positive feedback or encouragement (e.g., in carrying out a home program)?

[...] oferecem a você um retorno positivo ou incentivo (por exemplo, por você realizar as atividades terapêuticas em sua casa)?

A seguir, os resultados da análise comparativa sob a perspectiva dos procedimentos elencados por Barbosa (2004) (GRÁFICO 4). 
Gráfico 4 Procedimentos técnicos aplicados à tradução.

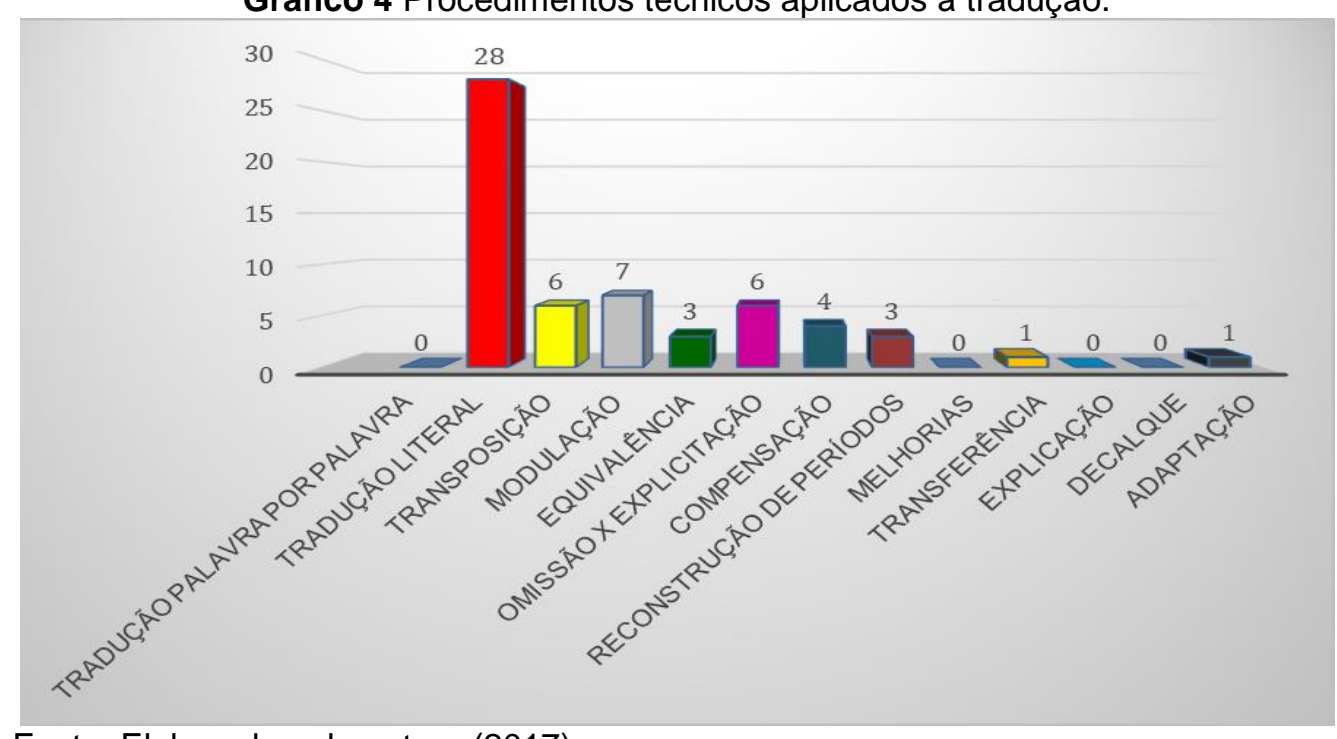

Fonte: Elaborado pela autora (2017).

Por fim, os procedimentos que não foram aplicados na tradução incluem o decalque, a explicação, a melhorias e a tradução palavra por palavra. Para este estudo, foram consideradas as questões como um todo, não a análise de unidades isoladas. Dessa forma, a tradução palavra por palavra ocorreu, mas não em uma questão inteira, pois estendeu-se ao uso em três ou quatro palavras dentro de uma frase e, portanto, não foi considerada. 

6 Discussão 



\section{DISCUSSÃO}

\subsection{0 processo de tradução sem a retrotradução}

O corpus analisado nesta pesquisa são os componentes do questionário. Dessa forma, pretendeu-se discutir os resultados obtidos por este estudo em concomitância com o seu objetivo, que foi realizar a tradução para a Língua Portuguesa do questionário The Measure of Processes of Care (MPOC-56), e verificar a inteligibilidade da tradução considerando a retirada da etapa da retrotradução. Para a inteligibilidade, foram analisados os princípios de acordo com Barbosa (1990) para delinear a análise comparativa entre o original, a tradução e o consenso resultante do brainstorming.

No que diz respeito à tradução, Aubert (1994) explicita que o tradutor deve ser fiel ao seu público alvo, obviamente, não desconsiderando, totalmente, o texto original, uma vez que o segundo texto nascerá da tradução de um outro anteriormente já produzido. Dessa maneira, "cada decisão tradutória acarreta vantagens e desvantagens específicas, ganhos e perdas, inevitavelmente. Ao afirmar alguma coisa, exclui-se outra (WEININGER, 2009, p. 25).

A tradução preliminar do questionário buscou compreender, também, por meio do processo tradutório, a utilização da etapa da "retrotradução" como forma de verificar e encontrar erros nas traduções realizadas. Para justificar o não uso da retrotradução nesse estudo, é relevante mencionar os dizeres de Venuti (1995, p. 17-18): "O significado é uma relação plural e contingente, não uma essência unificada imutável, assim uma tradução não pode ser julgada conforme conceitos matemáticos de equivalência semântica ou de correspondência biunívoca"6.

Ainda sobre a função do tradutor, Esteves (2005, p. 343) afirma que o processo de tradução pode ser compreendido como um processo de negociação da qual "negociam-se sentidos, éticas, visões, efeitos, preços, prazos e modos de trabalho". Esse aspecto pode ser comprovado pelos dizeres de Giusti e Befi-Lopes (2008) ao afirmarem que os protocolos, em sua maioria, são advindos de países estrangeiros e que, dessa forma, a tradução é o recurso mais utilizado para o meio científico. A dependência que o Brasil possui em relação aos países que

${ }^{6}$ Meaning is a plural and contingent relation, not an unchanging unified essence, and therefore a translation cannot be judged according to mathematics-based concepts of semantic equivalence or one-to-one correspondence. 
proporcionam um suporte maior a pesquisas reflete, dessa forma, no mercado científico e editorial. Ainda de acordo com Esteves (2005), o tradutor não se encontra livre para escolher a tradução e, muitas vezes, é subestimado ou colocado à prova com outros profissionais, como no caso das traduções na área da saúde.

Portanto, o que pode ser observado pelas traduções e adaptações elencadas na área da Fonoaudiologia é o uso da retrotradução como justificativa para encontrar possíveis equívocos cometidos nas traduções. $O$ que pesquisadores como Brislin (1970, 1986) e Guillemin, Bombardier e Beaton (1993) tentam é validar a tradução realizada aplicando um procedimento de verificação de erros, também chamado de retrotradução, cometidos baseados na equivalência semântica. A retrotradução, de acordo com teóricos da tradução não possui esse escopo. Para Nasser (2005), a retrotradução considera apenas a tradução literal do instrumento, sem detectar diferenças conceituais.

Para Ozolins (2009), a retrotradução é uma etapa muito conhecida dentro das organizações médicas, lideradas pela OMS, como forma de controlar o acesso a realização precisa e transferências de significados comparáveis entre as línguas em estudos internacionais de saúde. Corroborando com Ozolins (2009), Coulthard (2013) afirma que o processo de retrotradução só é mencionado e realizado pelos pesquisadores ao traduzir um protocolo, pois qualquer pessoa que tenha conhecimento da língua original do texto pode fazer a comparação do original e da tradução. Portanto, é possível observar que esse processo [retrotradução] não é relevante para a tradução em si, como aplicado a este estudo.

Ainda sobre a retrotradução e aos vários "tradutores" consultados para a elaboração do instrumento, Coulthard, (2013) avalia que se as agências financiadoras de pesquisas fornecessem suporte financeiro para projetos de adaptações culturais que fossem produzidas aqui no Brasil por pesquisadores brasileiros, a comunidade de pesquisas brasileiras seria capaz tanto de produzir quanto de traduzir esses questionários e seria, também, capaz de julgar os resultados por ela mesma (quanto a tradução realizada). Ao considerar essa importância do tradutor, é possível notar que este é o responsável por "exercer um papel comunicativo significativo, rompendo barreiras linguísticas e culturais, sem deixar de manter fidelidade à língua de origem, à língua de chegada e ao público a que a mensagem se destina" (LIMA, 2011, p. 46). 


\subsection{Brainstorming e a inteligibilidade}

O processo do brainstorming na concepção de Pasquali (1997), como já mencionado, tem por escopo reunir um grupo de pessoas para discutir um procedimento para se chegar a um consenso sobre determinado assunto. Neste estudo, o brainstorming foi realizado de acordo com a Figura 7 e mostrou-se eficaz para a formulação da versão final do questionário. Portanto, na perspectiva de Pasquali (1997), ao analisar os itens de um instrumento, deve-se realizar a análise semântica para verificar se todos os itens são compreensíveis para todos os membros da população em que será aplicado, considerando, dessa forma, as habilidades da população. Com base nas considerações de Pasquali (1997; 1998), o grupo chegou ao consenso que possibilitou a versão final do protocolo em língua portuguesa (ANEXO B). Por meio do brainstorming, foi possível descomplicar o processo de tradução e retirar o procedimento da retrotradução, uma vez que as dúvidas, sugestões e considerações eram resolvidas durante a reunião e, ao mesmo tempo, realizar a inteligibilidade do texto quanto aos aspectos lexicais, semânticos e culturais. É relevante mencionar, também, que o aspecto da fluência dos peritos em língua inglesa contribui para a efetividade da etapa do brainstorming e para a não realização da retrotradução.

\subsection{Análise comparativa}

A análise comparativa possibilitou avaliar a inteligibilidade do texto em português por meio dos procedimentos técnicos da tradução elaborados por Barbosa (2004) (ANEXO C). De acordo com os resultados apresentados, as divergências entre as línguas inglesa e portuguesa originam em mudanças semânticas e sintáticas para que o texto se apresente inteligível. Dessa forma, os procedimentos técnicos permitiram uma comparação criteriosa quanto às técnicas empregadas no ato tradutório e na etapa do brainstorming, proporcionando a inteligibilidade do instrumento em língua portuguesa.

Portanto, os procedimentos técnicos (BARBOSA, 2004) utilizados demonstram como é feita uma tradução; cabe ao tradutor refletir sobre questões de como modificá-lo, acrescentando ou excluindo elementos de forma a deixar o texto 
compreensível, reorganizando e adaptando de acordo com a cultura e a estrutura gramatical da língua de chegada.

De acordo com os resultados apresentados, o procedimento mais aplicado foi a tradução literal e, de acordo com Aubert (1998), esta é a técnica na qual o tradutor encontra as mesmas palavras e a mesma ordem sintática na língua traduzida. Entretanto, tem-se a modulação como um dos recursos mais utilizado, em virtude do questionário apresentar um caráter intermediário entre uma linguagem especializada e de fácil compreensão. Dessa forma, o questionário torna-se um instrumento complexo ao ser traduzido, pois pressupõe a reformulação de um discurso científico para um público não especializado.

Ao contrário do que os estudos de Beaton et al. (2002) e Brislin (1986) apontam em relação à adaptação, este procedimento não foi um dos recursos mais utilizados neste estudo, sendo, dessa forma, aplicado a apenas uma situação. Para Aubert (1998), a adaptação denota uma solução tradutória que estabelece uma equivalência parcial de sentido. A opção para a tradução do termo "the spastic diplegic" por "deficiência auditiva" para melhor compreensão do público a que o questionário se destina (Audiologia) corrobora com a explicação de Aubert (1998) e Barbosa (2004) de que a adaptação é um recurso que não terá equivalência perfeita na língua traduzida. A baixa utilização do recurso da adaptação também pode ser observada nas traduções e adaptações culturais de estudos elencados nesta pesquisa (QUADRO 1).

Portanto, por meio dos procedimentos utilizados, pode-se chegar ao consenso no brainstorming e proporcionar a inteligibilidade do questionário. Dessa forma, nos dizeres de Leffa (1996, p. 89), a inteligibilidade é compreendida como: "[a] qualidade de um texto quanto a sua capacidade de proporcionar facilidade de compreensão".

Ainda em concomitância com a inteligibilidade, Coscarelli (2002) explica a frequência como sendo um aspecto determinante para o processar da palavra dentro de uma sentença ou texto. Dessa forma, buscou-se padronizar certos léxicos no questionário, tais como: child $=$ filho(a), parente $=$ pai e/ou responsável, needs $=$ deficiência, equipment $=$ recursos auxiliares. 
7 Considerações Finais 



\section{CONSIDERAÇÕES FINAIS}

A propósito do objetivo desta pesquisa que verteu sobre a tradução do protocolo MPOC-56 e a avaliação da inteligibilidade do instrumento considerando a retirada da etapa da retrotradução, foi possível concluir que:

- a inteligibilidade do texto está intrinsecamente ligada à frequência de palavras às quais o leitor está exposto, possibilitando, dessa forma, à uma facilidade no ato de ler;

- o uso da retrotradução torna-se dispensável no processo de tradução de um protocolo quando utilizada a etapa do brainstorming. A retrotradução não é plausível para detectar erros da tradução, uma vez que cada idioma possui estrutura sintática distinta;

- uma tradução realizada por um tradutor profissional possui menos riscos de conter erros, pois a bagagem teórica compõe o profissionalismo do tradutor em concomitância com suas experiências acadêmicas. 

$\underline{\text { Referências }}$ 



\section{REFERÊNCIAS}

AIELLO, C. P.; LIMA, I. I. de; FERRARI, D. V. Validade e confiabilidade do questionário de handicap auditivo para adultos. Braz. j. otorhinolaryngol. (Impr.), São Paulo, v. 77, n. 4, p. 432-438, Ago. 2011.

ALSEM, M. W. Parents' perceptions of the services provided to children with cerebral palsy in the transition from preschool rehabilitation to school-based services. Child: care, health and development, 2016.

ALVES, F.; MAGALHÃES, C.; PAGANO, A. Traduzir com autonomia: estratégias para o tradutor em formação. São Paulo: Contexto, 2003.

AUBERT, F. H. As (in)fidelidades da tradução: servidões e autonomia do tradutor. 2.ed. Campinas. Ed. Unicamp, 1994.

Paulo: FFLCH/USP, 2001.

Introdução à metodologia de pesquisa terminológica bilíngue. São . Modalidades de tradução: teoria e resultados. TradTerm, v.5, n.1, São Paulo: CITRAT/FFLCH-USP, p.99-128, 1998.

AYRES, A. et al. Tradução e adaptação cultural do swallowing disturbance questionnaire para o português-brasileiro. Rev. CEFAC [online]. 2016, vol.18, n.4, p.828-834.

AZENHA Jr, J. Tradução Técnica e Condicionantes Culturais: Primeiros Passos para um Estudo Integrado. São Paulo: Humanitas, 1999.

BAGGIO, G. I. Tradução e adaptação transcultural do Test de Sintaxis de Aguado (TSA) para a língua portuguesa do Brasil. 2016. Dissertação (Mestrado em Fonoaudiologia) - Faculdade de Odontologia de Bauru, Universidade de São Paulo, Bauru, 2017. Disponível em:

$<$ http://www.teses.usp.br/teses/disponiveis/25/25143/tde-22062017-215346/>. Acesso em: 20 mar. 2017.

BARBOSA, H. G. Procedimentos Técnicos da Tradução. Campinas, SP: Pontes, 2004. Pontes, 1990.

Procedimentos técnicos da tradução: Uma nova proposta. Campinas:

BARBOZA, E.; NUNES, E. A inteligibilidade dos websites governamentais brasileiros e o acesso para usuários com baixo nível de escolaridade. Inclusão Social, Brasília, v. 2, n. 2, p. 19-33, abr./set. 2007.

BEATON, D. E. et al. Recommendations for the Cross-cultural adaptation of the DASH \& Quick DASH Outcome Measures. Institute for Work \& Health, 2007.

Disponível em: http://www.dash.iwh.on.ca/how-translate. Acesso em: 29 jun. 2016. 
BEATON, D. E., et al. Guidelines for the process of cross-cultural adaptation of selfreport measures. Spine, v.25, n.4, p. 3186-3191, 2000.

BELLIN, M. H. Parent and Health Care Professional Perspectives on Family-centered Care for Children with Special Health Care Needs: Are We on the Same Page?

Health \& Social Work, v.36, n.4, 1 Nov. p.281-290, 2011.

BENTO-GAZ, A. C. P.; BEFI-LOPES, D. M. Adaptação do teste Clinical Evaluation of Language Functions - 4th Edition para o Português Brasileiro. CoDAS, São Paulo, v.26, n.2, p.131-137, Abr. 2014.

BEVILACQUA, M. C.; TECH, E. A. Elaboração de um procedimento de avaliação de percepção de fala em crianças deficientes auditivas profundas a partir de cinco anos de idade. In: MARCHESAN, I. Q.; ZORZI, J. L.; GOMES, I. C. D. (Ed.). Tópicos em fonoaudiologia. São Paulo: Lovise, p. 411-433, 1996.

BJERRE, I. M. et al. Measure of Processes of Care (MPOC) applied to measure parent's perception of the habilitation process in Sweden. Child Care Health Dev. Mar; v.30, n.2, p.123-30, 2004.

BRAGATTO, E. L. et al. Versão brasileira do protocolo Overall Assessment of the Speaker's Experience of Stuttering - Adults (OASES-A). J. Soc. Bras. Fonoaudiol. [online]. 2012, vol.24, n.2, pp.145-151.

BRISLIN, R. W. Back-translation for cross-cultural research. J Cross-Cult Psych, n.3, p. $185-216,1970$.

. The wording and translation of research instruments. In Lonner, W.L. \& Berry, J.W. Field Methods in Cross-Cultural Research. Sage Publications, Newbury Park: 1986, p.137-164.

BULLINGER, M. Translating Health Status Questionnaires and Evaluating Their Quality: The IQOLA Project Approach. Journal of Clinical Epidemiology, v.51, n.11, Nov., p. 913-923, 1998.

CAMDEN, C. et al. Reorganizing Pediatric Rehabilitation Services to Improve Accessibility: Do We Sacrifice Quality? BMC Health Services Research, v.10, p. 227, 2010.

CANAVEZI, M. O.; ZANCHETTA, S. Tradução e adaptação do Amsterdam inventory auditory disability and handicap (AIADH) para o português brasileiro. 2015. ANAIS :: $30^{\circ}$ EIA - Bauru/SP - 2015.

CAPORALI, P. F. et al. Cross cultural translation and adaptation to Brazilian Portuguese of the Hearing Implant Sound Quality Index Questionnaire - (HISQUI19). CoDAS [online], vol.28, n.4, p.345-354. Epub Aug 11, 2016. 
CARDOSO, M.; HENDERSON, S.; CAPELLINI, S. A. Tradução e adaptação cultural brasileira do Detailed Assessment of Speed of Handwriting: equivalência conceitual e semântica. Audiol Commun Res.; v.19, n. 4, p. 321-6, 2014.

CARVALHO, C. A. F. de; LUCIO, P. S.; AVILA, C. R. B. de. Equivalência psicométrica da versão brasileira do Test of Pragmatic Language 2 - TOPL-2. CoDAS, São Paulo, v.27, n.4, p. 344-349, Ago. 2015.

CASTIQUINI, E. A. T. Escala de Integração Auditiva significativa: procedimento adaptado para a avaliação da percepção da fala. Dissertação (Mestrado em Distúrbios da Comunicação) - Pontifícia Universidade Católica de São Paulo, São Paulo, 1998.

CASTRO, A. S. O. de; et al. Versão brasileira do Dizziness Handicap Inventory. PróFono R. Atual. Cient. v.19 no.1, Barueri, jan./abr. 2007.

CHANUT, M. E. P. A noção de equivalência e a sua especificidade na tradução especializada. TradTerm, São Paulo, v. 19, novembro/2012, p. 43-70.

CHARAUDEAU, P. Discurso das mídias. São Paulo: Contexto, 2009.

COSCARELLI, C. V. Entendendo a leitura. Revista de Estudos da Linguagem, Belo Horizonte: UFMG, v.10, n.1, p.7-27, jan./jun. 2002.

. Em busca de um modelo de leitura. Revista de Estudos da

Linguagem, v.11, n.1, p. 119-147, 2003. Disponível em:

<http://periodicos.letras.ufmg.br/index.php/relin/article/view/2347>. Acesso em: 05 set. 2017.

COSTA, V. B. S. da. et al. Tradução e adaptação transcultural para o português brasileiro do teste Children's Communication Checklist-2. CoDAS, São Paulo, v.25, n.2, p. 115-119, 2013.

COULTHARD, R. J. Rethinking back-translation for the cross-cultural adaptation of health-related questionnaires: expert translators make backtranslation unnecessary. Tese (Doutorado) - Universidade Federal de Santa Catarina, Centro de Comunicação e Expressão, Programa de Pós-Graduação em Estudos da Tradução, Florianópolis, 2013.

CRUZ, A. D. da. et al. Planilha de triagem acústica da sala de aula: tradução e adaptação cultural para o Português Brasileiro. Audiol., Commun. Res. [online]. 2017, vol.22, e1766. Epub Mar 27, 2017.

CUNNINGHAM, B. J.; ROSENBAUM, P. L. Measure of Processes of Care: a review of 20 years of research. Developmental Medicine \& Child Neurology, v.56, n.5, p. 445-452, 2014. 
DONADON, C. et al. Children's Auditory Performance Scale (C.H.A.P.S) questionnaire: cross-cultural adaptation to Brazilian portuguese. In: 14 Congresso da Fundação Otorrinolaringologia, São Paulo. International Archives Of Otorrinolaryngology, 2015.

ESTEVES, L. M. R. Algumas reflexões sobre a ética na tradução. Estudos linguísticos XXXIV, p. 340-344, 2005. Disponível em:

$<$ http://www.gel.org.br/4publica-estudos-

2005/4publicaestudos2005pdfs/algumasreflexoes618.pdf?SQMSESSID=a38ffc79c8 2bcbe561e1c641326fd16c>. Acesso em: 14 ago. 2017.

FAHL, G. B.; GOULART, B. N. G. de. Transcultural adaptation of the Self-Evaluation of Communication Experiences After Laryngectomy (SECEL) instrument into Brazilian Portuguese. Audiol., Commun. Res., São Paulo, v.21, e1678, 2016 .

FELIPINI, L. M. G. Tradução e adaptação transcultural para a língua portuguesa do Brasil dos questionários Quality of Life in Swallowing Disorders (SWALQOL) e Quality of Care in Swallowing Disorders (SWAL-CARE) para idosos com disfagia neurogênica. 2016. Tese (Doutorado em Fonoaudiologia) -

Faculdade de Odontologia de Bauru, Universidade de São Paulo, Bauru, 2016. Disponível em: <http://www.teses.usp.br/teses/disponiveis/25/25143/tde-03052017194852/>. Acesso em: 13 set. 2017.

FERREIRA, K. et al. Translation and adaptation of functional auditory performance indicators (FAPI). J. Appl. Oral Sci., Bauru, v. 19, n. 6, p. 586-598, Dez. 2011. Disponível em: <http://www.scielo.br/scielo.php?script=sci_arttext\&pid=S167877572011000600008\&Ing=en\&nrm=iso >. Acesso em: 24 set. 2017.

FERREIRA, P. E. A. et al. Tinnitus handicap inventory: adaptação cultural para o Português brasileiro. Pró-Fono R. Atual. Cient., Barueri, v.17, n. 3, p. 303-310, Dez. 2005.

FORDHAM, L., GIBSON, F., BOWES, J. Information and professional support: Key factors in the provision of family-centred early childhood intervention services. Child: Care, Health and Development, v.38, n.5, p. 647-653, 2011.

FORTUNATO-TAVARES, T.; et al. Crianças com implante coclear: habilidades comunicativas e qualidade de vida. Brazilian Journal of Otorhinolaryngology, São Paulo, v. 78, n. 1, p. 15-25, jan/fev, 2012.

FREDERIGUE-LOPES, N. B.; BEVILACQUA, M. C.; COSTA, O. A. Munich Music Questionnaire: adaptação para a língua portuguesa e aplicação em usuários de implante coclear. CoDAS [online], v.27, n.1, p.13-20, 2015.

GIUSTI, E.; BEFI-LOPES, D. M. Tradução e adaptação transcultural de instrumentos estrangeiros para o Português Brasileiro (PB). Pró-Fono R Atual Cient, v. 20, n.3, p. 207-10, 2008. 
GONCALVES, M. I. R.; REMAILI, C. B.; BEHLAU, M. Equivalência cultural da versão brasileira do Eating Assessment Tool - EAT-10. CoDAS, São Paulo, v.25, n. 6, p. 601-604, 2013.

GONSALEZ, E. C. de M.; ALMEIDA, K. de. Adaptação cultural do questionário Speech, Spatial and Qualities of Hearing Scale (SSQ) para o Português Brasileiro. Audiol., Commun. Res. [online], vol.20, n.3, p.215-224, 2015.

GRUNWALD, D.; GOLDFARB, N. M. Translation for Quality Control of Informed Consent Forms. First Clinical Research - Journal of Clinical Research Best Practice, Fevereiro, 2006. Disponível em: https://firstclinical.com/journal/2006/0602_Back.pdf. Acesso em: 16 mar. 2017.

GUILLEMIN, F.; BOMBARDIER, C.; BEATON, D. Cross-cultural adaptation of healthrelated quality of life measures: literature review and proposed guidelines. $\mathbf{J}$ Clin Epidem.; v.46, n.12, p.1417-1432, 1993.

HARKNESS, J.A.; SCHOUA-GLUSBERG, A. Questionnaires in Translation. ZUMANachrichten Spezial, v.3, p. 87-127, 1998.

HATJE-FAGGION, V. Tradutores em caminhos interculturais - a tradução de palavras culturalmente determinadas. In: HATJE-FAGGION, V.; BELL SANTOS, C. A.; BESSA, C. R. (org.). Tradução e Cultura, Rio de Janeiro: 7Letras, 2011.

HERMANS, T. Translation and Normativity. In Schäffner C (Ed.) Translation and norms. Beijing: Foreign Language Teaching and Research Press, 2007.

HIMURO, N., KOZUKA, N.; MORI, M. Measurement of family-centred care: translation, adaptation and validation of the Measure of Processes of Care (MPOC56 and -20) for use in Japan. Child Care Health Dev. Maio, v.39, n.3, p. 358-65, 2013.

HOLANDA, W. T. G.; LIMA, M. L. C. de; FIGUEIROA, J. N. Adaptação transcultural de um instrumento de avaliação do handicap auditivo para portadores de perda auditiva induzida pelo ruído ocupacional. Ciênc. saúde coletiva, Rio de Janeiro, v.16, supl. 1, p. 755-767, 2011.

HOLMES, J. The Name and Nature of Translation Studies. The Translation Studies Reader (ed. Lawrence Venuti). London \& New York: Routledge, 2000, p. $172-185$.

IQOLA. The international quality of life assessment (IQOL) project. 2011. Disponível em: http://www.iqola.org. Acesso em: 13 jul. 2017.

JACOB, R. T. de S. et al. TELEGRAM: contribuição na indicação de tecnologia assistiva para indivíduos com deficiência auditiva. CoDAS; v.29, n.1, e20160012, 2017.

portuguesa. Rev. bras. educ. espec. [online], vol.16, n.3, p.359-373, 2010. 
JACOBSON, R. Aspectos linguísticos da tradução. In: Linguística e Comunicação. São Paulo: Cultrix, 1971.

JOACHIM, K. C. Assessing the Structural Validity of the Measure of Processes of Care (MPOC-20) in Children with Epilepsy. Electronic Thesis and Dissertation Repository. Paper 2610, 2014.

JORGE, B. M.; LEVY, C. C. A. da C.; GRANATO, L. Adaptação Cultural da Escala de Qualidade de Vida Familiar (Family Quality of Life Scale) para o Português Brasileiro. CoDAS, São Paulo, v. 27, n. 6, p. 534-540, Dez. 2015.

KING, S.; ROSENBAUM, P.; KING, G. The Measure of Processes of Care, MPOC: a means to assess family-centred behaviours of health care providers. Hamilton, ON: Neurodevelopmental Clinical Research Unit, Chedoke-McMaster Hospitals, 1995.

KNOX, V.; MENZIES, S. Using the measure of processes of care to assess parents' views of a paediatric therapy service. Br J Occup Ther, v.68, n.3, p. 110-6, 2005.

KROHLING, L. L.; BEHLAU, M.; VERDUYCKT, I. Equivalência cultural da versão brasileira do Questionnaire des Symptômes Vocaux. CoDAS, São Paulo, v.28, n.4, p. 454-458, ago. 2016.

LARA, J. D.; MELO, T. M.; MECCA, F. F. D. N. Adaptação Transcultural do Questionário Teachers Evaluation of Aural/ Oral Performance of Children (TEACH). In: $\mathbf{2 6}^{\circ}$ Encontro Internacional de Audiologia, 2011, Maceió. Anais do $26^{\circ}$ Encontro Internacional de Audiologia, 2011.

LEANDRO, F. S. M. et al. LittlEars $\AA^{\circledR}$ - Questionário auditivo: adaptação semântica e cultural da versão em Português Brasileiro em pais de crianças com deficiência auditiva. Audiol., Commun. Res., São Paulo, v. 21, e1640, 2016.

LEFFA, V. J. Aspectos da leitura: uma perspectiva psicolinguística. Porto Alegre: Sagra, 1996.

LEVY, C. C. A. da C.; RODRIGUES-SATO, L. C. C. B. Questionnaire validation PEACH on Brazilian Portuguese. CoDAS [online], vol.28, n.3, p.205-211. Epub May 31, 2016.

LIMA, N. de. O princípio cognitivo da tradução literária: um relato linguísticoteológico do processo de tradução do livro The Cognitive Principle of Christian Theology: A hermeneutical study of the Revelation and Inspiration of the Bible, de Fernando Canale. São Paulo, 2011. 62 f. Dissertação (Pós-Graduação em Estudos Teológicos). Pós-Gradução em Teologia, UNASP - campus Engenheiro Coelho.

LINDAU, T. A.; ROSSI, N. F.; GIACHETI, C. M. Adaptação transcultural do Preschool Language Assessment Instrument: Segunda Edição. CoDAS [online], vol.26, n.6, p.428-433, 2014. 
LOVAT, A. et al. Family caregivers' perceptions of hospital-based allied health services post-stroke: use of the Measure of Processes of Care to investigate processes of care. Aust Occup Ther J, Jun, v.57, n.3, p.167-73, 2010.

MAGALHAES JUNIOR, H. V. et al. Tradução e adaptação transcultural do Northwestern Dysphagia Patient Check Sheet para o português brasileiro. CoDAS, São Paulo, v.25, n. 4, p. 369-374, 2013.

MAIA, M. de F. S. C. A Intervenção Precoce nas Associações Portuguesas de Paralisia Cerebral: Percepções das Famílias, dos Profissionais e dos Diretores de Serviço. Tese (Doutorado), 2012. Universidade do Minho: Instituto de Educação.

MORETI, F. T. Validação da versão brasileira da Voice Symptom Scale - VoiSS [tese]. São Paulo: Universidade Federal de São Paulo, 2011.

NASSER, R. A Method for Social Scientists to Adapt Instruments From One Culture to Another: The Case of the Job Descriptive Index. Journal of Social Sciences, v.1, n.4, p. 232-237, 2005.

NELSON, C. L. Intelligibility in world Englishes: theory and application. New York, NY: Routledge, 2011.

NEVES, M. de B. et al. Adaptação transcultural para o Português Brasileiro do Teste de Rastreamento Western Aphasia Battery - Revised: um estudo preliminar. CoDAS, São Paulo, v.26, n.1, p. 38-45, Fev. 2014.

O'NEIL, M. E., ROBERT, J. P.; SARAH, L. W. Relationship of therapists' attitudes, children's motor ability, and parenting stress to mothers' perceptions of therapists' behaviors during early intervention. Physical Therapy, v.81, n.8, p. 1412-1424, 2001.

ORLANDI, A. C. L.; BEVILACQUA, M. C. Deficiência auditiva profunda nos primeiros anos de vida: procedimento para a avaliação da percepção da fala. Pró-Fono R. Atual. Cient., Barueri (SP), v. 10, n. 2, p. 87-91, set. 1998.

ORLANDI, E. P. Análise de discurso: princípios e procedimentos. 5 ed. Campinas: Pontes, 2003.

OSHIMA, M. et al. Early Listening Function (ELF): adaptação para a língua portuguesa. Rev. soc. bras. fonoaudiol. [online], vol.15, n.2, p.191-196, 2010.

OZOLINS, U. Back translation as a means of giving translators a voice. Interpreting and Translation, v.1, n.2, p. 1-13, 2009.

PAGURA, R. A interpretação de conferências: interfaces com a tradução escrita e implicações para a formação de intérpretes e tradutores. São Paulo, 2003.

PAIVA, M. M. G. Traduções: Qualidade e Avaliação. Administração no 63, vol. XVII, 2004-1.․ 295-304. 
PASQUALI, L. Princípios de elaboração de escalas psicológicas. Revista de Psiquiatria Clínica, v.25, 206-213, 1998.

Psicometria: teoria e aplicações. Brasília: Universidade de Brasília, 1997.

PAULINELLI, B. R.; GAMA, A. C. C.; BEHLAU, M. Validação do Questionário de Performance Vocal no Brasil. Rev. soc. bras. fonoaudiol. [online], vol.17, n.1, p.8591, 2012.

POLIT, D.; BECK, C.; HUNGLER, B. Fundamentos de pesquisa em enfermagem: Método, avaliação e utilização. 5ํㅡㄹ. ed. Porto Alegre: Artmed; 2004.

RAHI, J. S. et al. Health services experiences of parents of recently diagnosed visually impaired children. British Journal of Ophthalmology, v.89, n.2, p. 213-218, 2005.

RAMOS, R. de L. Adaptação cultural e validação do "The Language Screening Test - LAST" versões A e B para o português do Brasil. 2013. 73 f. Dissertação (Mestrado) - Universidade Estadual de Campinas, Faculdade de Ciências Médicas, Campinas, SP. Disponível em:

<http://www.bibliotecadigital.unicamp.br/document/?code=000926142>. Acesso em: 11 abr. 2017.

RIBEIRO, J. C. S.; BERRETIN-FELIX, G. Tradução e adaptação do protocolo "modified mann assessment of swallowing ability" (MMASA) para o português brasileiro. Anais.. Bauru: Faculdade de Odontologia de Bauru, 2015.

RIBEIRO, L. L.; PAULA, K. M. P. de; BEHLAU, M. Qualidade de Vida em Voz na População Pediátrica: validação da versão brasileira do Protocolo Qualidade de Vida em Voz Pediátrico. CoDAS, São Paulo, v.26, n.1, p. 87-95, Fev. 2014.

RICARTE, A.; OLIVEIRA, G.; BEHLAU, M. Validação do protocolo Perfil de Participação e Atividades Vocais no Brasil. CoDAS [online], vol. 25, n.3, p. 242-9, 2013.

ROBINSON, D. Construindo o tradutor. São Paulo: EDUSC, 2002.

ROSSI, N. F. et al. Adaptação cultural do Test of Narrative Language (TNL) para o Português Brasileiro. CoDAS, São Paulo, v. 28, n.5, p. 507-516, Out. 2016.

SANTOS, H. H. de A. N. M. dos. et al. Tradução e avaliação preliminar da versão em Português do Questionário de Autoavaliação Vocal para Transexuais de Homem para Mulher. CoDAS, São Paulo, v. 27, n.1, p. 89-96, Fev. 2015.

SANTOS, L. G. dos. Phrases in Noise Test (PINT): adaptação cultural para o português brasileiro e aplicabilidade na avaliação do sistema de frequência modulada. 2015. Dissertação (Mestrado em Fonoaudiologia) - Faculdade de Odontologia de Bauru, Universidade de São Paulo, Bauru, 2015. Acesso em: 14 fev.2017. 
SOUZA, M. R. F. de; OSBORN, E.; GIL, D.; IORIO, M. C. M. Tradução e adaptação do questionário ABEL: Auditory Behavior in Everyday Life para o Português Brasileiro. J. Soc. Bras. Fonoaudiol. [online], vol.23, n.4, p.368-375, 2011.

STONE, B. L. et al. Children with Chronic Complex Medical Illnesses: Is Inpatient Care Family-Centered? J Pediatr Rehabil Med., Jan 1; v.1, n.3, p. 237-243, 2008.

VASSOLER, T. M. F.; CORDEIRO, M. L. Brazilian adaptation of the Functioning after Pediatric Cochlear Implantation (FAPCl): comparison between normal hearing and cochlear implanted children. J. Pediatr. (Rio J.), Porto Alegre, v.91, n. 2, p. 160-167, Abr. 2015.

VENUTI, L. Adaptation, Translation, Critique. Journal of Visual Culture, vol.6; $1^{\text {a }}$ ed. Los Angeles, London, New Delhi and Singapore: SAGE Publications, p. 25-43, 2007. Routledge, 2004.

The translation studies reader. $2^{\mathrm{a}}$ ed. New York and London:

. The Translator's Invisibility. A history of translation. London; New York: Routledge 1995.

VIEIRA, P. L. S. O Estudo de Tradução Técnica e Científica: Uma Análise de seu Desenvolvimento Histórico. Tradução em Revista, v.21, p. 132-164, 2016.

WANG, W. L.; LEE, H. L.; FETZER, S. J.; Challenges and strategies of instrument translation. Western Journal Nursing Research, v.28, n.3, p. 310-321, 2006.

WARE, J. E. Jr.; SHERBOURNE, C. D. The MOS 36-item short-form health survey (SF-36). I. Conceptual framework and item selection. Med Care, v.30, p. 473-483, 1992.

WEININGER, M. J. Estrela guia ou utopia inalcançável. Uma breve reflexão sobre a equivalência na tradução. In: CARDOZO, M.M.; HEIDERMANN, W.; WEININGER, M.J. (Org.). A Escola Tradutológica de Leipzig. 1. ed. Frankfurt/Main: Peter Lang Verlag, v. 1, p. 19-28, 2009.

WILD, D. et al. ISPOR Task Force for Translation and Cultural Adaptation. Principles of good practice for the translation and cultural adaptation process for patientreported outcomes (PRO) measures: report of the ISPOR Task Force for translation and cultural adaptation. Value Health. v.8, n.2, p.94-104, 2005.

WILKINS, A. et al. Evaluation of the processes of family-centred care for young children with intellectual disability in Western Australia. Child: care, health and development, v.36, n.5, p.709-718, 2010.

ZAMBON, F. et al. Equivalência cultural da versão brasileira do Vocal Fatigue Index - VFI. CoDAS, São Paulo, v. 29, n. 2, e20150261, 2017. 
ZOCOLI, A. M. F.; MORATA, T. C.; MARQUES, J. Mendes. Adaptação para o português brasileiro do questionário: Youth Attitude to Noise Scale (YANS). Braz. j. otorhinolaryngol. (Impr.), São Paulo, v.75, n.4, p. 485-492, ago. 2009. 
Apêndices 

APÊNDICE A - Material entregue aos peritos para considerações sobre a tradução do instrumento.

Material referente ao projeto de pesquisa da aluna GISELI BUENO BERTI, do Programa de Pós-Graduação em Fonoaudiologia da Faculdade de Odontologia de Bauru da Universidade de São Paulo, nível Mestrado, área de concentração Processos e Distúrbios da Comunicação.

Título do projeto: Tradução e adaptação para a Língua Portuguesa do questionário The Measure of Processes of Care (MPOC-56): análise da inteligibilidade do instrumento.

Orientadora: Dra. Adriane de Lima Mortari Moret

\section{ATIVIDADE:}

Reunião do grupo de discussão (brainstorming)

Prezados Peritos,

Esta pesquisa consiste na tradução do protocolo MPOC-56 para utilização na área da Fonoaudiologia com o objetivo de avaliar a satisfação dos pais em relação aos serviços prestados tanto pelos profissionais que atendem o paciente, como em relação ao Centro de Tratamento como um todo, abarcando todos os funcionários que, de forma direta ou indireta, trabalham com o paciente e com seus familiares.

Para a versão em língua portuguesa, foi realizada, primeiramente, a tradução do protocolo, considerando a questão semântica, sintática e lexical e, por fim, a revisão da própria pesquisadora (tradutora). Em seguida, o processo de tradução atingiu a etapa do brainstorming. O brainstorming consiste, de acordo com Pasquali (1997) em um grupo de discussão que, por meio de pensamentos e sugestões, chegam a um senso comum em relação a ideias inovadoras e criativas sobre o tópico em discussão (neste caso, o questionário e a adaptação do mesmo para a língua portuguesa), averiguando a tradução para a língua de chegada (português).

Esta tradução consiste na adequação semântica, sintática e lexical em língua portuguesa dos itens do questionário, em virtude da reunião dos dois peritos em fonoaudiologia e conhecedores da língua inglesa e a pesquisadora (tradutora) do 
instrumento. Abaixo, encontram-se dois quadros que correspondem as considerações que os peritos realizarão e que irão compor o quadro de análises e discussões da pesquisa.

Solicitamos sua colaboração em analisar previamente 0 material encaminhado e apontar as suas considerações na terceira coluna do quadro (CONSIDERAÇÕES DO PERITO) até o dia 06/09/2017, data da nossa reunião de brainstorming. Não há necessidade de encaminhar previamente os apontamentos antes da nossa reunião, somente levá-los para a discussão na data estabelecida.

\begin{tabular}{|c|c|c|}
\hline ORIGINAL & TRADUÇÃO & CONSIDERAÇÕES DO PERITO \\
\hline $\begin{array}{l}\text { We would like to } \\
\text { understand and measure the } \\
\text { experiences of parents who have a } \\
\text { child with disability. In particular we } \\
\text { wish to know about your perceptions } \\
\text { of the care you have been receiving } \\
\text { over the past year from your child's } \\
\text { Treatment (Reabilitation) Centre. } \\
\text { The questions in this } \\
\text { section are based on what parents, } \\
\text { like yourself, have told us about the } \\
\text { way care is sometimes offered. We } \\
\text { would like you to indicate how much } \\
\text { the event or situation happens (or } \\
\text { doesn't happen) to you at your } \\
\text { treatment centre. You are asked to } \\
\text { answer each question on a scale } \\
\text { from } 7 \text { (To a Great Extent) do } 1 \\
\text { (Never). } \\
\text { The care that you and your } \\
\text { child received from the Centre may } \\
\text { bring you into contact with many } \\
\text { individuals. The questions on this } \\
\text { form are grouped by who these } \\
\text { contacts are, as described below. }\end{array}$ & 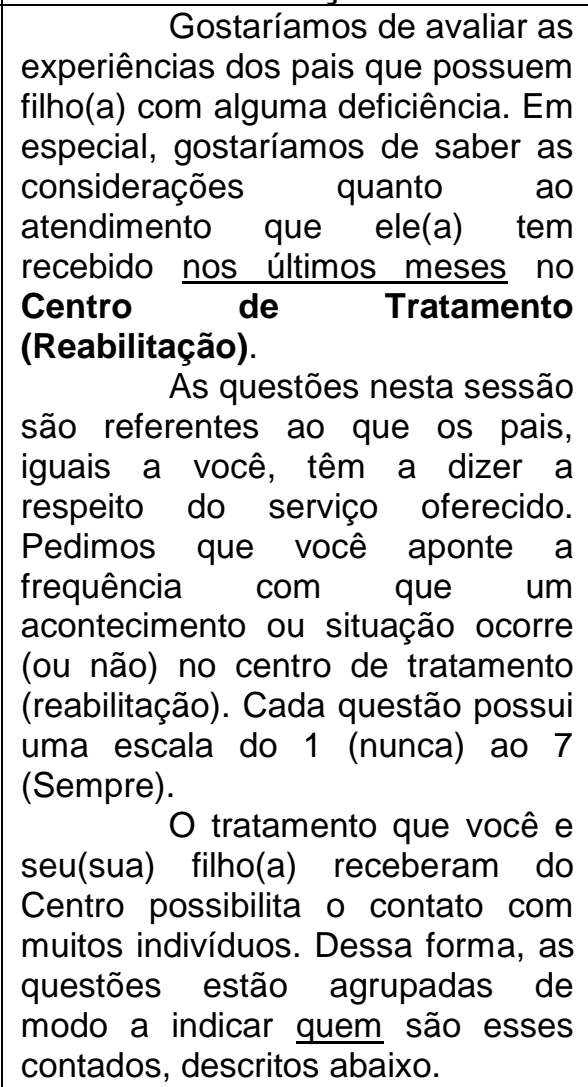 & \\
\hline $\begin{array}{l}\text { 1. PEOPLE: refers to those } \\
\text { individuals who work directly with } \\
\text { you or your child. These may } \\
\text { include psycologists, therapists, } \\
\text { social works, doctors, teachers, etc. } \\
\text { 2. CENTRE: refers to all staff from } \\
\text { the centre, whether involved directly } \\
\text { with your child or not. In addition to } \\
\text { health care people they may include } \\
\text { support staff such as office staff, } \\
\text { housekeepers, administrative } \\
\text { personnel, etc. }\end{array}$ & $\begin{array}{l}\text { 1. PESSOAS: Se refere àqueles } \\
\text { indivíduos que trabalham } \\
\text { diretamente com você ou seu filho. } \\
\text { Podem incluir psicólogos, } \\
\text { terapeutas, assistentes sociais, } \\
\text { médicos, professores, etc. } \\
\text { 2. INSTITUIÇÃO: Se refere a toda } \\
\text { equipe do centro, envolvida } \\
\text { diretamente ou não com seu filho. } \\
\text { Além das pessoas do centro de } \\
\text { tratamento, a equipe também pode } \\
\text { incluir grupos de apoio que } \\
\text { trabalham no escritório, serviços } \\
\text { gerais, departamento }\end{array}$ & \\
\hline
\end{tabular}




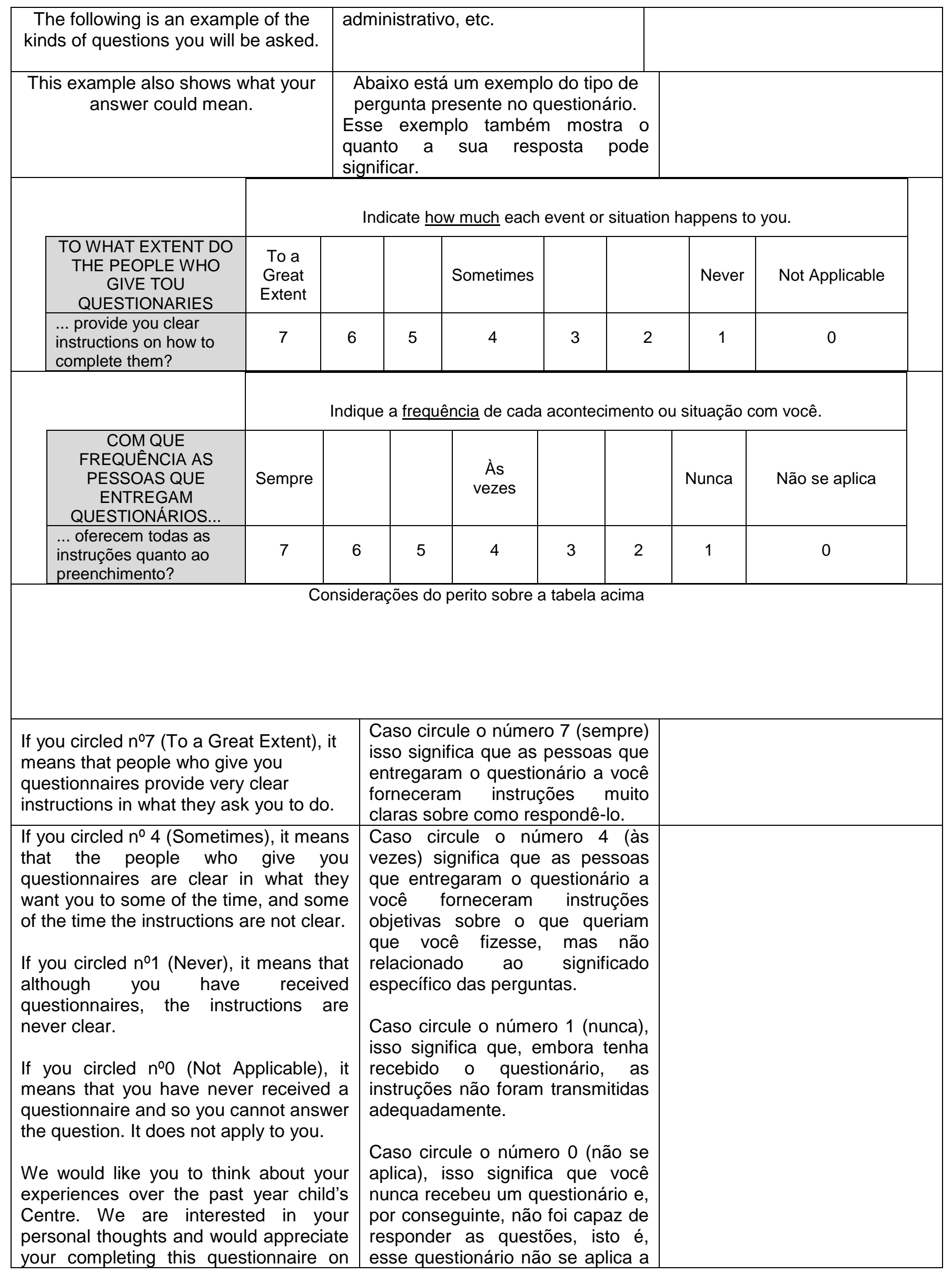


your own without discussing it with anyone.

For each question, please indicate how much the event or situation happens to you by circling one number (from 1 to 7 ) that you feel best fits your experience. When answering these questions, we would like to you to think about the Centre from which you first found about this study.

For easy reference, we have written the name of that Centre on this line: você ou a sua realidade.

Gostaríamos que você pensasse sobre as experiências vividas nos últimos meses com seu filho no Centro. Estamos interessados em sua opinião para completar esse questionário que é de caráter confidencial.

Por favor, para cada questão indique a frequência da ocorrência, circule apenas um número (de 1 a 7) que melhor descreve a sua experiência. Enquanto responde a essas questões, gostaríamos que você pensasse também no Centro em que se realiza esse estudo.

Para facilitar, escrevemos o nome deste Centro nesta linha:
People refers to those individuals who work directly with you or your child. These may include teachers, psychologists, therapists, social workers, doctors, etc.

People refers to those individuals who work directly with you or your child. These may include teachers, psychologists, therapists, social workers, doctors, etc.

\begin{tabular}{|l|l}
\hline IN THE PAST YEAR & $\begin{array}{l}\text { D } \\
\text { tera }\end{array}$ \\
\hline
\end{tabular}

$\begin{array}{lll}\begin{array}{l}\text { Pessoas se referem àqueles } \\ \text { indivíduos }\end{array} & \begin{array}{l}\text { refe } \\ \text { que }\end{array}\end{array}$ diretamente com você ou seu filho.

Esses podem incluir professores, psicólogos, terapeutas, assistentes sociais, médicos, etc.

Pessoas se referem àqueles indivíduos que trabalham

diretamente com você ou seu filho. Esses podem incluir professores, psicólogos, terapeutas, assistentes sociais, médicos, etc.

Durante 0 procedimento terapêutico ...

TO WHAT EXTENT DO THE
PEOPLE WHO WORK WITH YOUR CHILD...

\begin{tabular}{l|l}
1. & ... suggest therapy plans that
\end{tabular} fit with your family's needs and lifestyle?

2. $\quad$... fully explain treatment choices to you?

3. $\quad$... offer you positive feedback or encouragement (e.g., in carrying out a home program)?

Com que frequência os PROFISSIONAIS QUE CUIDAM DE SEU FILHO...

... sugerem terapias que se adaptam as necessidades e ao estilo de vida da família?

... explicam as possibilidades de tratamento?

... oferecem retorno positivo ou estimulação (por exemplo em como realizar uma assistência domiciliar)?

$4 . \quad$ explain things to your child in a way that your child understands?

5. take the time to establish rapport with you or your child when changes occur in your services?

... explicam claramente os assuntos a criança para que ele entenda?

... estabelecem uma harmonia entre você e seu filho quando ocorrem mudanças nos serviços prestados? 


\begin{tabular}{|c|c|c|c|}
\hline 6. & $\begin{array}{l}\text { expectations for your child, so } \\
\text { that all agree on what is best? }\end{array}$ & $\begin{array}{l}\text {... debatem com você sobre } \\
\text { perspectivas para decidirem o } \\
\text { melhor para a criança? }\end{array}$ & \\
\hline 7. & $\begin{array}{l}\text { make sure that your child's } \\
\text { skills are known to all persons } \\
\text { working with your child, so the } \\
\text { skills are carried across } \\
\text { services and service } \\
\text { providers? }\end{array}$ & $\begin{array}{l}\text {... verificam se as habilidades da } \\
\text { criança são reconhecidas pelos } \\
\text { profissionais que atuam com ela e, } \\
\text { dessa forma, as habilidades são } \\
\text { realizadas entre os prestadores de } \\
\text { serviços e os serviços? }\end{array}$ & \\
\hline 8. & $\begin{array}{l}\text { tell you about options for } \\
\text { treatment or services for your } \\
\text { child (e.g., equipment, school, } \\
\text { therapy)? }\end{array}$ & $\begin{array}{l}\text {... expressam opções para } \\
\text { tratamento ou serviços para o } \\
\text { paciente (como aparelhos, escola, } \\
\text { terapia)? }\end{array}$ & \\
\hline 9. & $\begin{array}{l}\text { accept you and your family in } \\
\text { a nonjudgemental way? }\end{array}$ & $\begin{array}{l}\text {... aceitam você e sua família sem } \\
\text { algum tipo de preconceito? }\end{array}$ & \\
\hline 10. & $\begin{array}{l}\text { provide ideas to help you work } \\
\text { with the health care "system"? }\end{array}$ & $\begin{array}{l}\text {... orientam você sobre os direitos e } \\
\text { o sistema de saúde? }\end{array}$ & \\
\hline 11. & $\begin{array}{l}\text { recognize the demands of } \\
\text { caring for a child with special } \\
\text { needs? }\end{array}$ & $\begin{array}{l}\text {... reconhecem os cuidados } \\
\text { necessários ao lidar com uma } \\
\text { criança deficiente? }\end{array}$ & \\
\hline 12. & $\begin{array}{l}\text { trust you as the "expert" on } \\
\text { your child? }\end{array}$ & $\begin{array}{l}\ldots \text { acreditam que você é um } \\
\text { especialista sobre seu filho (a)? }\end{array}$ & \\
\hline 13. & $\begin{array}{l}\text { look at the needs of your } \\
\text { "whole" child (e.g., at mental, } \\
\text { emotional, and social needs) } \\
\text { instead of just at physical } \\
\text { needs? }\end{array}$ & $\begin{array}{l}\text {... observam todas necessidades } \\
\text { da criança como um todo (mental, } \\
\text { emocional, social) além da } \\
\text { deficiência física? }\end{array}$ & \\
\hline 14. & $\begin{array}{l}\text { show sensitivity to your } \\
\text { family's feelings about having } \\
\text { a child with special needs } \\
\text { (e.g., your worries about your } \\
\text { child's health or function)? }\end{array}$ & $\begin{array}{l}\text {... demonstram sensibilidade com } \\
\text { os sentimentos da família em ter } \\
\text { um filho com deficiência (por } \\
\text { exemplo, suas preocupações com } \\
\text { a saúde do seu filho ou funções? }\end{array}$ & \\
\hline 15. & $\begin{array}{l}\text { anticipate your concerns by } \\
\text { offering information even } \\
\text { before you ask? }\end{array}$ & $\begin{array}{l}\text {.. disponibilizam informações e } \\
\text { prestam auxílio antes mesmo de } \\
\text { você pedir? }\end{array}$ & \\
\hline 16. & $\begin{array}{l}\text { make sure you have a chance } \\
\text { during visits to the centre to } \\
\text { say what is important to you? }\end{array}$ & $\begin{array}{l}\text {... certificam que você tem } \\
\text { oportunidades durante as visitas ao } \\
\text { centro para dizer o que é } \\
\text { importante para você? }\end{array}$ & \\
\hline 17. & $\begin{array}{l}\text { let you choose when to } \\
\text { receive information and the } \\
\text { type of information you want? }\end{array}$ & $\begin{array}{l}\ldots \text { permitem que você peça } \\
\text { informações e como as deseja } \\
\text { receber? }\end{array}$ & \\
\hline 18. & $\begin{array}{l}\text { remember personal details } \\
\text { about your child or family } \\
\text { when speaking with you? }\end{array}$ & $\begin{array}{l}\text {... lembram de detalhes pessoais } \\
\text { da criança ou da família quando } \\
\text { conversam com você? }\end{array}$ & \\
\hline 19. & $\begin{array}{l}\text { tell you about the reasons for } \\
\text { treatment or equipment? }\end{array}$ & $\begin{array}{l}\text {... explicam as razões para um } \\
\text { tratamento ou aparelhos? }\end{array}$ & \\
\hline 20 . & $\begin{array}{l}\text { follow up at the next } \\
\text { appointment on any concerns } \\
\text { you discussed at the previous } \\
\text { one? }\end{array}$ & $\begin{array}{l}\ldots \text { acompanham datas de } \\
\text { compromissos futuros das quais } \\
\text { foram agendadas anteriormente? }\end{array}$ & \\
\hline 21. & $\begin{array}{l}\text { make sure that at least one } \\
\text { team member is someone who } \\
\text { works with you and your family } \\
\text { over a long period of time? }\end{array}$ & $\begin{array}{l}\text {... reconhecem pelo menos que um } \\
\text { membro da equipe trabalha com } \\
\text { você e sua família por mais tempo? }\end{array}$ & \\
\hline 21. & provide opportunities for you & $\ldots$ fornecem oportunidades para & \\
\hline
\end{tabular}




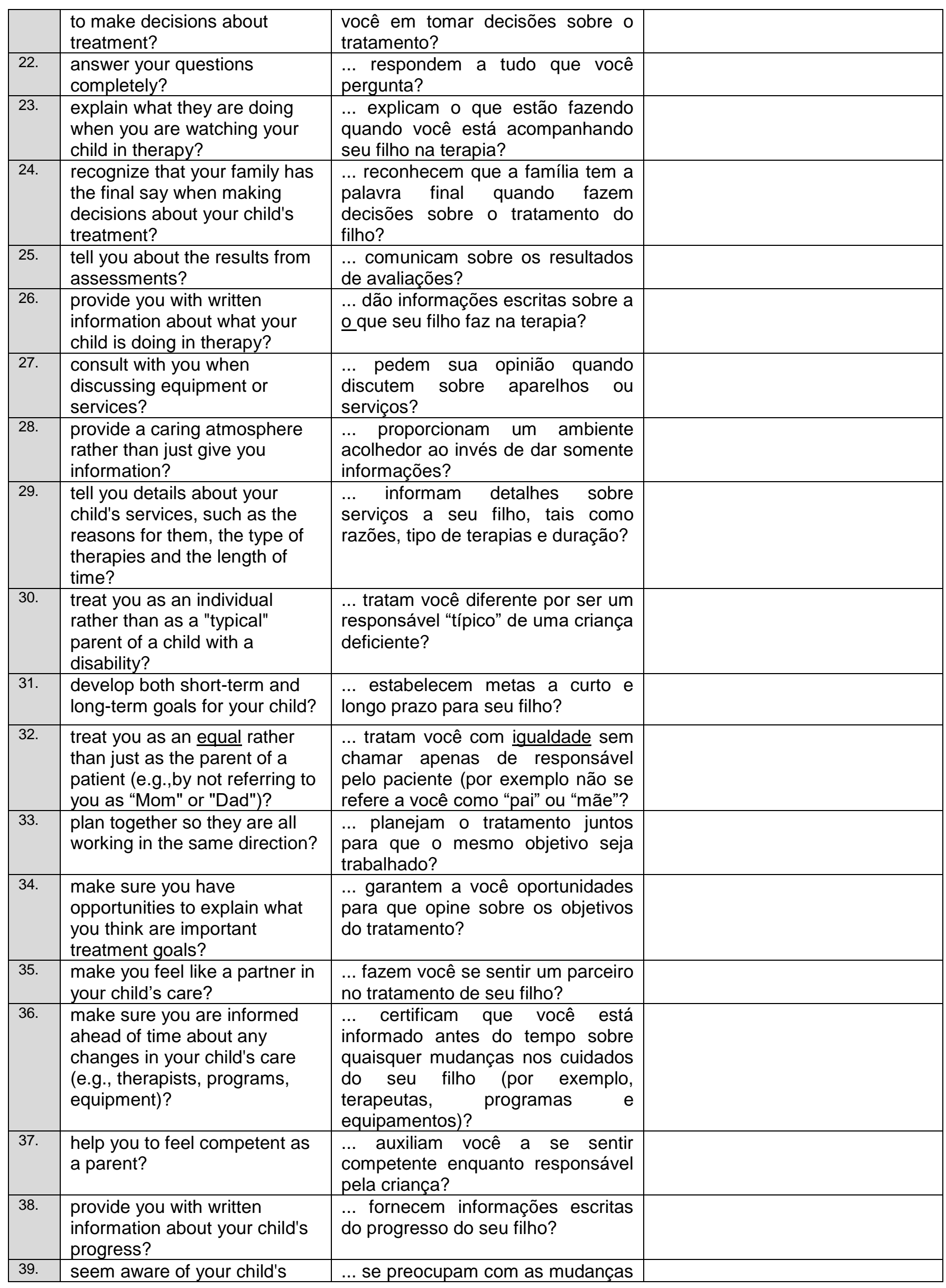




\begin{tabular}{|c|c|c|c|}
\hline & $\begin{array}{l}\text { changing needs as he/she } \\
\text { grows? }\end{array}$ & do seu filho enquanto cresce? & \\
\hline 40. & $\begin{array}{l}\text { provide enough time to talk so } \\
\text { you don't feel rushed? }\end{array}$ & $\begin{array}{l}\text {... tem disponibilidade de horário } \\
\text { para atender a você? }\end{array}$ & \\
\hline 41. & $\begin{array}{l}\text { treat you and your family as } \\
\text { people rather than as a "case" } \\
\text { (e.g., by not referring to you by } \\
\text { diagnosis, such as "the spastic } \\
\text { diplegic")? }\end{array}$ & $\begin{array}{l}\text {... tratam você e sua família como } \\
\text { pessoas e não apenas como um } \\
\text { "estudo" (por exemplo, não se } \\
\text { refere a você como um diagnóstico, } \\
\text { tal como "disfasia")? }\end{array}$ & \\
\hline 42. & $\begin{array}{l}\text { listen to what you have to say } \\
\text { about your child's needs for } \\
\text { equipment, services, etc. }\end{array}$ & $\begin{array}{l}\text {... consideram sua opinião sobre as } \\
\text { necessidades do seu filho por } \\
\text { aparelhos ou serviços? }\end{array}$ & \\
\hline 43. & $\begin{array}{l}\text { make themselves available to } \\
\text { you as a resource (e.g., } \\
\text { emotional support, advocacy, } \\
\text { information)? }\end{array}$ & $\begin{array}{l}\text {... estão disponíveis para você } \\
\text { enquanto um recurso (por ex. apoio } \\
\text { emocional, proteção, informação)? }\end{array}$ & \\
\hline 44. & $\begin{array}{l}\text { give you information about } \\
\text { your child that is consistent } \\
\text { from person to person? }\end{array}$ & $\begin{array}{l}\text {... fornecem informações sobre sua } \\
\text { criança que sejam consistentes de } \\
\text { pessoa a pessoa? }\end{array}$ & \\
\hline 45. & $\begin{array}{l}\text {... suggest therapy plans that } \\
\text { fit with your family's needs and } \\
\text { lifestyle? }\end{array}$ & $\begin{array}{l}\ldots \text { sugerem terapias que se } \\
\text { adaptam as necessidades e } \\
\text { estilo de vida da família? }\end{array}$ & \\
\hline \multicolumn{2}{|c|}{$\begin{array}{l}\text { Centre refers to all staff from the } \\
\text { centre, whether involved directly with } \\
\text { your child or not. In addition to health } \\
\text { care professionals, the people may } \\
\text { include support staff such as office } \\
\text { staff, housekeepers, administrative } \\
\text { personnel, etc. }\end{array}$} & $\begin{array}{l}\text { Centro se refere à equipe do centro } \\
\text { quando envolvidos diretamente } \\
\text { com seu filho ou não. Além dos } \\
\text { serviços de saúde profissionais, as } \\
\text { pessoas podem incluir equipe de } \\
\text { suporte, tais como pessoal do } \\
\text { escritório, empregados, da } \\
\text { administração, etc. }\end{array}$ & \\
\hline \multicolumn{2}{|c|}{$\begin{array}{l}\text { In the past year } \\
\text { To what extent does the centre } \\
\text { where you receive services... }\end{array}$} & $\begin{array}{l}\text { Durante o procedimento } \\
\text { terapêutico ... } \\
\text { Com que frequência o centro onde } \\
\text { você recebe os serviços... }\end{array}$ & \\
\hline 46. & $\begin{array}{l}\text { have information available to } \\
\text { you in various forms, such as } \\
\text { a booklet, kit, video, etc.? }\end{array}$ & $\begin{array}{l}\text {... fornece informações disponíveis } \\
\text { a você de várias maneiras, tais } \\
\text { como folheto, kit, vídeo, etc.? }\end{array}$ & \\
\hline 47. & $\begin{array}{l}\text { have support staff that are } \\
\text { polite and courteous to you } \\
\text { and your family? }\end{array}$ & $\begin{array}{l}\text {... possui uma equipe prestadora e } \\
\text { atenciosa com você e sua família? }\end{array}$ & \\
\hline 48. & $\begin{array}{l}\text { give you information about the } \\
\text { types of services offered at the } \\
\text { Centre or in your community? }\end{array}$ & $\begin{array}{l}\text {... fornece informações sobre os } \\
\text { tipos de serviços oferecidos no } \\
\text { Centro ou em sua comunidade? }\end{array}$ & \\
\hline 49. & $\begin{array}{l}\text { promote family-to-family } \\
\text { gatherings for social, } \\
\text { informational or shared } \\
\text { experiences? }\end{array}$ & $\begin{array}{l}\text {... promove reuniões familiares } \\
\text { para compartilhar experiências } \\
\text { social, informativa e profissional? }\end{array}$ & \\
\hline 50. & $\begin{array}{l}\text { provide opportunities for } \\
\text { special guests to speak to } \\
\text { parents on topics of interest? }\end{array}$ & $\begin{array}{l}\text {... promove oportunidades para } \\
\text { encontros com especialistas e pais } \\
\text { sobre assuntos do interesse? }\end{array}$ & \\
\hline 51. & $\begin{array}{l}\text { provide support to help cope } \\
\text { with the impact of childhood } \\
\text { disability (e.g., by advocating } \\
\text { on your behalf or informing } \\
\text { you of assistance programs)? }\end{array}$ & $\begin{array}{l}\text {... fornece suporte para enfrentar } \\
\text { os impactos da deficiência infantil } \\
\text { (como proteção de seus interesses } \\
\text { ou programas assistenciais)? }\end{array}$ & \\
\hline 52. & $\begin{array}{l}\text { notify you about the reasons } \\
\text { for upcoming case } \\
\text { conferences, meetings, etc. } \\
\text { about your child? }\end{array}$ & $\begin{array}{l}\text {... notifica a você sobre as razões } \\
\text { de necessidades de conferências, } \\
\text { reuniões, etc. sobre seu filho? }\end{array}$ & \\
\hline 53. & have information available & ... possui informações disponíveis & \\
\hline
\end{tabular}




\begin{tabular}{|l|l|l|l|}
\hline & $\begin{array}{l}\text { about your child's disability } \\
\text { (e.g., its causes, how it } \\
\text { progresses, future outlook)? }\end{array}$ & $\begin{array}{l}\text { sobre a deficiência da criança (por } \\
\text { exemplo, causas, avanços, } \\
\text { perspectivas futuras)? }\end{array}$ & $\begin{array}{l}\text { fornece orientações em como } \\
\text { provide advice on how to get } \\
\text { information or to contact other } \\
\text { parents (e.g., Centre's parent } \\
\text { obter informações ou on contato } \\
\text { resource library)? outros responsáveis (por } \\
\text { exemplo, um recurso de banco de } \\
\text { dados para os pais do Centro)? }\end{array}$ \\
\hline 55. & $\begin{array}{l}\text { provide opportunities for the } \\
\text { entire family to obtain } \\
\text { information? }\end{array}$ & $\begin{array}{l}\ldots \text { garante oportunidades para que } \\
\text { toda a família obtenha as } \\
\text { informações? }\end{array}$ \\
\hline 56. & $\begin{array}{l}\text { have general information } \\
\text { available about different } \\
\text { concerns (e.g., financial costs } \\
\text { or assistance, genetic } \\
\text { counselling, dating and } \\
\text { sexuality)? }\end{array}$ & $\begin{array}{l}\text { acessíveis sobre outros interesses } \\
\text { (custos, genética, compromissos, } \\
\text { sexualidade)? }\end{array}$ & \\
\hline
\end{tabular}


$\underline{\text { Anexos }}$ 

ANEXO A - Measure of Processes of Care-56

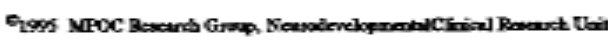

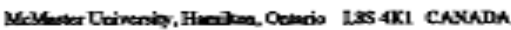

STUDY NO.

\section{PROCESSES OF CARE OUESTIONNAIRE}

We would like to understand and measure the experiences of parents who have a child with a disability. In particular we wish to know about your perceptions of the care you have been receiving ower the past rear from your child's Treatment (Rehabilitation) Centre.

The questions in this section ane based on what parents, like yourself, hase told us about the way care is sometimes offered. We would like you to indicate how much the event or situation happens (or doesn't happen) to you at your treatment centre. You are asked to answer each question on a scale from 7 (To a Great Extent) to 1 (Never).

The care that you and your child receive from the Centre may bring you into contact with many individuals. The questions on this form are grouped by who these contacts are, as described below.

1. PEOPLE: refers to those individuals who work directly with you or your child. These may include psychologists, therapists, social workers, doctors, teachers, etc.

2. CENTRE: refers to all staff from the centre, whether involved directly with your child or not. In addition to bealth care people they may include support staff such as office staff, housekeepers, administrative personnel, etc. 
The following is an example of the kinds of questions you will be askod.

This example also shows what your answer could mean.

Indicate hors muxh each event or sibuation happens to you.

\section{TO WHAT EXTENT DO THE PEOPLE WHO GIVE YOU QUESTIONNAIRES...}

... provide you with clear instructions on how to complete them?

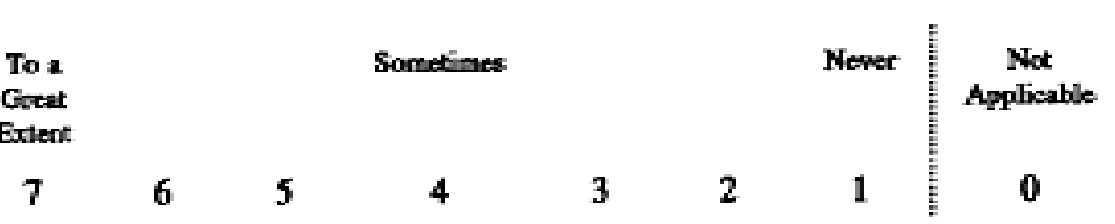

If you circled $\mathbf{3 7}$ (To a Great Extent), it means that the people who give you questionnaires prowide very clear instructions in what they ask you to do.

If you circled 44 (Sometimes), it means that the people who give you questionnaires are clear in what they want you to do some of the time, and some of the time the instructions are not clear.

If you circled $\$ 1$ (Never), it means that although you have received questionnaires, the instructions are never clear.

If you circled to (Not Applicable), it means that you have never received a questionnaire and so you cannot answer the question. It does not apply to you. 
We would like you to think about your experiences ower the past year at your child's Centre. We are interested in your personal thoughts and would appreciate your completing this questionnaire on your own without discussing it with anyone.

For each question, please indicate bow much the event or situation happens to you by circling one number (from 1 to 7 ) that you feel best fits your experience. When answering these questions, we would like you to think about the Centre from which you first found out about this study.

For easy reference, we have written the name of that Centre on this line:

PEOPLE refers to those individuals who work directly with you or your child. These may inchude teachers, psychologists, therapists, social workers, doctors, etc.

\section{IN THE PAST YEAR}

TO WHAT EXTENT DO THE PEOPLE WHO WORK WITH YOUR CHILD...

1. ... suggest therapy plans that fit with your family's needs and lifestyle?

2. ... fully explain treatmene choices to you?

3. ... offer you positive feedback or encouragemenc (e.g., in carrying out a home program)?

4. ... explain things to your child in a way that your child understands?

5. .... take the time to establish rapport with you or your child when changes occur in your services?

6. ... discuss with you everyone's expectarions for your child, so that ail agree on what is best?
Indicate how much this event or situation happens to you.

\begin{tabular}{|c|c|c|c|c|c|c|c|}
\hline $\begin{array}{l}\text { To a } \\
\text { Gocat } \\
\text { Extent }\end{array}$ & & & neti & & & Never & $\begin{array}{c}\text { Not } \\
\text { Applicable }\end{array}$ \\
\hline 7 & 6 & 5 & 4 & 3 & 2 & 1 & 0 \\
\hline$\tau$ & 6 & 5 & 4 & 3 & 2 & 1 & 0 \\
\hline 7 & 6 & 5 & 4 & 3 & 2 & 1 & 0 \\
\hline 7 & 6 & 5 & 4 & 3 & 2 & 1 & 0 \\
\hline 7 & 6 & 5 & 4 & 3 & 2 & 1 & 0 \\
\hline 7 & 6 & 5 & 4 & 3 & 2 & 1 & 0 \\
\hline
\end{tabular}




\section{IN THE PAST YEAR}

TO WHAT EXTENT DO THE PEOPLE WHO WORK WTH YOUR CHILD.

7. .... make sure that your child's skills are known to all persons working with rour child, 30 the skilss are carried across services and service providers?

8. -.- tell you about options for treatment or services for your child (e.g., equipment, school, therapp)?

9. .... accept you and your family in a nonjudgemental way?

10. .... provide ideas to help you work with the health care "system"?

11. ... recognize the demands of caring for a child with special noeds?

12. ... trust you as the "expert" an your child?

13. ... look at the needs of you "whole" child (e.g... at memal, emotional, and social needs) instead of just at physical nesds?

14. ... show sensitivity to your family's felings about having a child with special needs (e.g., your worries about your child's health or functionj?

15. .... anticipate your concerns by offering information even before you ask?

16. ... make sure you have a chance during visits to the centre to say what is important to you?

17. ... let you choose when to receive information and the type of information you want?
Indicate hove much this event or sintuation happens to you.

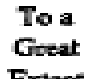

Sometimes

Exaten

7

6

5

4

7

6

5

$T$

6

5

7

6

5

$T$

6

5

$T$

6

5

6

5

7

3

3

2

4

4

4

4

4

4

2

vare

Nat
Asplisable

0

0

D

D

D

0

0

D

0

D

0 


\section{IN THE PAST YEAR}

TO WHAT EXTENT DO THE PEOPLE WHO WORK WTTH YOUR CHILD.

18. -... remember personal details about your child or family when speaking with you?

19. ... tell you about the reasons for treatment or equipment?

20. ... follow up at the next appointment on any concerns you discassed at the previous one?

21. ... make sure that at least one team member is someone who works with you and your family over a long period of time?

22. ... provide opportunities for you to make decisions about treatment?

23. ... answer your questions completely?

24. ... explain what they are doing when you are watching your child in therapy?

25. ... recognize that your family has the final say when making decisions about your child's treatment?

26. ... vell you about the results from assessments?

27. ... provide you with written information about what your child is doing in therapy?

28. ... consalt with you when discussing equipment or services?

29. ... provide a caring atmosphere rather than just give you information?

Inficate bow much this enent or situation happens to you

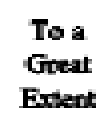

Sometimes

Exent

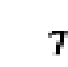

7

7

7

7

6

6

5

4

4

4

65

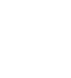

2

$7 \quad 6 \quad 5$

4

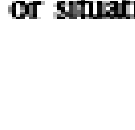

happens to you-
Norrs

7

7

7

6

5

4

4

4

3

2

3

2

3

2

Nowas Not
Applicale

$\begin{array}{lll}7 & 6 & 5\end{array}$

4

3

2

6

5

4

3

4

3

2

2

7

7

$\begin{array}{lllllll:l}7 & 6 & 5 & 4 & 3 & 2 & 1 & 0 \\ 7 & 6 & 5 & 4 & 3 & 2 & 1 & 0\end{array}$




\section{IN THE PAST YEAR}

TO WHAT EXTENT DO THE PEOPLE WHO WORK WITH YOUR CHILD...

30. ... tell you details about your child's services, sach as the reasons for them, the type of therapies and the length of time?

31. ... treat you as an individual rather than as a "typical" parent of a child with a disability?

32. ... develop both short-term and long-term goals for your child?

33. ... treat you as an equal rather than just as the parent of a patient (e.g-, by not referring to as "Mom" or "Dad')?

34. ... plan together so they are all working in the same direction?

35. ... make sure you have opportanities to explain what you think are important trearment goals?

36. ... make you feel like a partner in your child's care?

37. ... make sure you are informed ahead of time about any changes in your child's care (e.g., therapists, programs, eqaipment)?

38. ... help you to feel competent as a parent?

39. ... provide you with written information about your child's progress?

40. ... seem aware of your child's changing neads as he/she grows?
To 2

Grest

Exiem

\section{$\tau$}

7

7

(1)

3

7

7

$\tau$

$\tau$

7

7

7
Indicate how much this event or situation happens to you.

Sornetimes

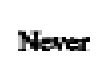

Not

Applicable

65

4

3

2

0

0

0

0

0

0

0

0

0

0

0 

YOUR CHILD.

\footnotetext{
41. ... provide enough time to talk so you don't feel rushed?

42. .... treat you and your family as people ralher than as a

"case" (e.g., by not referring to you by diagnosis. such as "the spastic diplegic" "r?

43. ... listen to what you have to say about your child's needs for equipment, services, etc.?

44. -.. make themselves available to you as a resource (e.g.,

45. … give you information about your child that is

emotional support, adrocacy, informationj?
45. ... give you information about your child that is consistent from person to person?
}

Indicate how much this event or sibuation happens to you.

To a

Extent
Sonetimes

6

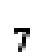

T

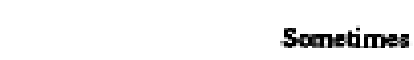

5

6

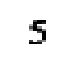

4

4

4

65

65
6
3

3

2

\section{Hation happens to you.
Wever}

ver Not Applicable

D

0

0

0

0

CENTRE refers to all staff from the centre, whether inmolwed diroctly with your child or not. In addition to health care professionals, these poople may include support staff such as office staff, housekeepers; administrative personnel; etc.

\section{IN THE PAST YEAR}

TO WHAT EXTENT DOES THE CENTRE WHERE YOU RECEIVE SERVICES..

46. -.- hawe information available to you in various forms, such as a booklet, kit, video, etc.?

47. .... have support staff that are polite and courteous to you and your family?
Indicate bow much the ewent or situation happens to you.

\begin{tabular}{|c|c|c|c|c|c|c|c|}
\hline $\begin{array}{l}\text { To a } \\
\text { Great } \\
\text { Esteat }\end{array}$ & & & meti & & & Nefer & $\begin{array}{c}\text { Not } \\
\text { Applirelite }\end{array}$ \\
\hline 7 & 6 & 5 & 4 & 3 & 2 & 1 & 0 \\
\hline 7 & 6 & 5 & 4 & 3 & 2 & 1 & 0 \\
\hline
\end{tabular}




\section{IN THE PAST YEAR}

TO WHAT EXTENT DOES THE CENTRE WHERE YOU RECEIVE SERVICES...

48. ... give you information about the types of services offered at the Centre or in your community?

49. ... promote family-to-family gatherings for social, informational or shared experiences?

50. ... provide opportunities for special guests to speak to parents on topics of interest?

51. ... provide support to help cope with the impact of childhood disability (e.g., by advocating on your behalf or informing you of assistance programs)?

52. ... notify you about the reasons for upcoming case conferences, meetings, etc. about your child?

53. ... have information available about your child's disability (e.g., its causes, how it progresses, future outlook)?

54. ... provide advice on how to get information or to contact other parents (e.g., Centre's parent resource library)?

55. ... provide opportunities for the entire family to obtain information?

56. ... have general information available about different concerns (e.g., financial costs or assistance, genetic counselling, dating and sexuality)?
Indicate how much the event or situation happens to you.
To a

Gres:

Extent
7

7

7

7

6

6

6

s

5

6

5

6

5

65

65

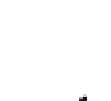

sometimes

6

5

5 tion happens to you
Never

2
Applicable

0

0

$\mathbf{0}$

0

0

0

0

0

0
Please continue to the next page... 
What is your relationship to your child with special needs?

$\begin{array}{llll}\square & \text { Natural Mother } & \square & \text { Natural Father } \\ \square & \text { Stepmother } & \square & \text { Stepfather } \\ \square & \text { Adoptive Mother } & \square & \text { Adoptive Father } \\ \square & \text { Foster Mother } & \square & \text { Foster Father }\end{array}$

$\square \quad$ Other Guardian, please specify:

On what date did you complete this questionnaire?

degrinonih/year

ANY COMMENTS:

PLEASE CHECK THAT BOTH SIDES OF ALL PAGES ARE COMPLETED

CONFIDENTIAL WHEN COMPLETED

THANK YOU!! 


\section{QUESTIONÁRIO DE PROCEDIMENTOS DE TRATAMENTO}

Gostaríamos de entender e avaliar as experiências dos pais que possuem filho(a) com alguma deficiência. Em especial, gostaríamos de saber as considerações quanto ao atendimento que ele(a) tem recebido no último ano no Centro de Tratamento (Reabilitação).

As questões nesta sessão são referentes ao que os pais, iguais a você, têm a dizer a respeito do serviço oferecido. Pedimos que você aponte a frequência com que um acontecimento ou situação ocorre (ou não) no centro de tratamento (reabilitação). Você responderá a cada questão em uma escala do 1 (Nunca) ao 7 (Sempre).

O tratamento que você e seu (sua) filho(a) receberam do Centro possibilita o contato com muitos indivíduos. Dessa forma, as questões estão agrupadas de modo a indicar quem são esses contatos, descritos abaixo.

1. PESSOAS: Se refere àqueles indivíduos que trabalham diretamente com você ou seu filho (a). Podem incluir psicólogos, terapeutas, assistentes sociais, médicos, professores, etc.

2. INSTITUIÇÃO: Se refere a toda equipe do centro, envolvida diretamente ou não com seu filho(a). Além das pessoas do centro de tratamento, a equipe pode incluir grupos de apoio, tais como, pessoas que trabalham no escritório, serviços gerais, departamento administrativo, etc.

Abaixo encontra-se um exemplo do tipo de pergunta presente neste questionário.

Este exemplo também mostra o que a sua resposta pode significar.

\begin{tabular}{|c|c|c|c|c|c|c|c|c|}
\cline { 2 - 8 } \multicolumn{1}{c|}{} & \multicolumn{7}{c|}{ Indique a frequência de cada acontecimento ou situação com você. } \\
\hline $\begin{array}{c}\text { COM QUE } \\
\begin{array}{c}\text { FREQUÊNCIA AS } \\
\text { PESSOAS QUE } \\
\text { ENTREGAM } \\
\text { QUESTIONÁRIOS A } \\
\text { VOCÊ... }\end{array}\end{array}$ & Sempre & $\begin{array}{c}\text { Quase } \\
\text { sempre }\end{array}$ & $\begin{array}{c}\text { Muitas } \\
\text { vezes }\end{array}$ & $\begin{array}{c}\text { Às } \\
\text { vezes }\end{array}$ & $\begin{array}{c}\text { Poucas } \\
\text { vezes }\end{array}$ & Raramente & Nunca & $\begin{array}{c}\text { Não se } \\
\text { aplica }\end{array}$ \\
\hline $\begin{array}{c}\ldots \text { oferecem } \\
\text { instruções claras } \\
\text { quanto ao } \\
\text { preenchimento? }\end{array}$ & 7 & 6 & 5 & 4 & 3 & 2 & 1 & 0 \\
\hline
\end{tabular}


Caso circule o número 7 (sempre) isso significa que as pessoas que entregaram o questionário a você forneceram instruções muito claras sobre como respondê-lo.

Caso circule o número 4 (às vezes) significa que as pessoas que entregam questionário a você fornecem instruções claras sobre o que querem que você faça, mas em partes, pois para o restante, as instruções não foram claras.

Caso circule o número 1 (nunca), significa que, embora tenha recebido o questionário, as instruções não foram claras.

Caso circule o número 0 (não se aplica), isso significa que você nunca recebeu um questionário e, por conseguinte, não pode responder as questões, isto é, esse questionário não se aplica a você ou a sua realidade.

Gostaríamos que você pensasse sobre as experiências vividas no último ano com seu (sua) filho(a) no Centro. Estamos interessados em sua opinião e gostaríamos que você completasse o questionário sem conversar com outras pessoas.

Por favor, para cada questão indique a frequência com que cada situação ou evento aconteceu com você, circule apenas um número (de 1 a 7) que melhor descreva a sua experiência. Enquanto responde a essas questões, gostaríamos que você pensasse no centro onde seu (sua) filho (a) recebe acompanhamento.

Para nossa referência, escreva o nome do centro nesta linha: 
Pessoas se referem àqueles indivíduos que trabalham diretamente com você ou seu filho. Esses podem incluir professores, psicólogos, terapeutas, assistentes sociais, médicos, etc.

\begin{tabular}{|c|c|c|c|c|c|c|c|c|c|}
\hline \multicolumn{2}{|c|}{ NO ÚLTIMO ANO, } & \multicolumn{8}{|c|}{ Indique a frequência } \\
\hline & $\begin{array}{l}\text { QUE FREQUÊNCIA AS } \\
\text { OAS QUE TRABALHARAM } \\
\text { SEU(SUA) FILHO(A)... }\end{array}$ & Sempre & & & $\begin{array}{c}\text { Às } \\
\text { vezes }\end{array}$ & & & Nunca & $\begin{array}{c}\text { Não se } \\
\text { aplica }\end{array}$ \\
\hline 1. & $\begin{array}{l}\text {... sugerem } \\
\text { terapêuticos adaptados as } \\
\text { necessidades e ao estilo de } \\
\text { vida da sua família? }\end{array}$ & 7 & 6 & 5 & 4 & 3 & 2 & 1 & 0 \\
\hline 2. & $\begin{array}{l}\text {... explicam completamente as } \\
\text { possibilidades de tratamento? }\end{array}$ & 7 & 6 & 5 & 4 & 3 & 2 & 1 & 0 \\
\hline 3. & $\begin{array}{l}\text {... oferecem a você um retorno } \\
\text { positivo ou incentivo (por } \\
\text { exemplo, por você realizar as } \\
\text { atividades terapêuticas em sua } \\
\text { casa)? }\end{array}$ & 7 & 6 & 5 & 4 & 3 & 2 & 1 & 0 \\
\hline 4. & $\begin{array}{l}\text {... explicam os assuntos de } \\
\text { forma que seu (sua) filho (a) } \\
\text { entenda? }\end{array}$ & 7 & 6 & 5 & 4 & 3 & 2 & 1 & 0 \\
\hline 5. & $\begin{array}{l}\text {... reservam um momento para } \\
\text { estabelecer um vínculo com } \\
\text { você e seu filho quando } \\
\text { ocorrem mudanças nos } \\
\text { serviços prestados? }\end{array}$ & 7 & 6 & 5 & 4 & 3 & 2 & 1 & 0 \\
\hline 6. & $\begin{array}{l}\text {... conversam com você sobre } \\
\text { as expectativas de todos } \\
\text { quanto ao que é melhor para a } \\
\text { criança? }\end{array}$ & 7 & 6 & 5 & 4 & 3 & 2 & 1 & 0 \\
\hline 7. & $\begin{array}{l}\text {... verificam se as habilidades } \\
\text { do(a) seu (sua) filho(a) são } \\
\text { reconhecidas } \\
\text { profissionais que atuam com } \\
\text { ele(a) e, dessa forma, são } \\
\text { efetuadas entre serviços e } \\
\text { prestadores de serviços? }\end{array}$ & 7 & 6 & 5 & 4 & 3 & 2 & 1 & 0 \\
\hline 8. & $\begin{array}{l}\text {... apresentam opções de } \\
\text { tratamento ou serviços para } \\
\text { seu (sua) filho(a) (como } \\
\text { recursos auxiliares, escola, } \\
\text { terapia)? }\end{array}$ & 7 & 6 & 5 & 4 & 3 & 2 & 1 & 0 \\
\hline 9. & $\begin{array}{l}\text {... aceitam você e sua família } \\
\text { sem fazer nenhum tipo de } \\
\text { julgamento? }\end{array}$ & 7 & 6 & 5 & 4 & 3 & 2 & 1 & 0 \\
\hline 10. & $\begin{array}{l}\text {... orientam você de modo a } \\
\text { ajudá-lo a lidar com o sistema } \\
\text { de saúde? }\end{array}$ & 7 & 6 & 5 & 4 & 3 & 2 & 1 & 0 \\
\hline 11. & $\begin{array}{l}\text {... reconhecem os cuidados } \\
\text { necessários ao lidar com uma } \\
\text { criança com deficiência? }\end{array}$ & 7 & 6 & 5 & 4 & 3 & 2 & 1 & 0 \\
\hline 12. & $\begin{array}{l}\text {... acreditam que você seja um } \\
\text { especialista sobre seu filho } \\
\text { (a)? }\end{array}$ & 7 & 6 & 5 & 4 & 3 & 2 & 1 & 0 \\
\hline 13. & $\begin{array}{l}\text {... observam as necessidades } \\
\text { do seu(sua) filho(a) como um } \\
\text { todo (mental, emocional, } \\
\text { social) além da deficiência } \\
\text { física? }\end{array}$ & 7 & 6 & 5 & 4 & 3 & 2 & 1 & 0 \\
\hline
\end{tabular}




\begin{tabular}{|l|l|l|l|l|l|l|l|l|l|}
\hline 14. & $\begin{array}{l}\text {.. demonstram sensibilidade } \\
\text { com os sentimentos da família } \\
\text { em ter um(a) filho(a) com } \\
\text { deficiência (por exemplo, suas } \\
\text { preocupações com a saúde } \\
\text { do(a) seu (sua) filho(a) ou } \\
\text { funções? }\end{array}$ & 7 & 6 & 5 & 4 & 3 & 2 & 1 & 0 \\
\hline $\begin{array}{l}\text { antecipam informações e } \\
\text { prestam auxílio antes mesmo } \\
\text { de você pedir? }\end{array}$ & 7 & 6 & 5 & 4 & 3 & 2 & 1 & 0 \\
\hline 15. & & & & & & & & \\
\hline
\end{tabular}

\begin{tabular}{|c|c|c|c|c|c|c|c|c|c|}
\hline \multicolumn{2}{|c|}{ Durante o procedimento terapêutico ... } & \multicolumn{8}{|c|}{ Indique a frequência } \\
\hline \multicolumn{2}{|c|}{  } & Sempre & & & $\begin{array}{c}\text { Às } \\
\text { vezes }\end{array}$ & & & Nunca & $\begin{array}{l}\text { Não se } \\
\text { aplica }\end{array}$ \\
\hline 16. & $\begin{array}{l}\text {.. certificam que você tem } \\
\text { oportunidades durante as } \\
\text { visitas ao centro para dizer o } \\
\text { que é importante para você? }\end{array}$ & 7 & 6 & 5 & 4 & 3 & 2 & 1 & 0 \\
\hline 17. & $\begin{array}{l}\ldots \text { permitem que você peça } \\
\text { informações e como as deseja } \\
\text { receber? }\end{array}$ & 7 & 6 & 5 & 4 & 3 & 2 & 1 & 0 \\
\hline 18. & $\begin{array}{l}\text {... lembram de detalhes } \\
\text { pessoais do(a) seu (sua) } \\
\text { filho(a) ou da família quando } \\
\text { conversam com você? }\end{array}$ & 7 & 6 & 5 & 4 & 3 & 2 & 1 & 0 \\
\hline 19. & $\begin{array}{l}\text {... explicam as razões para um } \\
\text { tratamento ou recursos } \\
\text { auxiliares? }\end{array}$ & 7 & 6 & 5 & 4 & 3 & 2 & 1 & 0 \\
\hline 20. & $\begin{array}{l}\text {.. continuam no próximo } \\
\text { atendimento } \\
\begin{array}{l}\text { discutidos previamente? } \\
\text { assuntos }\end{array}\end{array}$ & 7 & 6 & 5 & 4 & 3 & 2 & 1 & 0 \\
\hline 21. & $\begin{array}{l}\text {... asseguram que pelo menos } \\
\text { um membro da equipe já tenha } \\
\text { trabalhado com você e sua } \\
\text { família por um longo período? }\end{array}$ & 7 & 6 & 5 & 4 & 3 & 2 & 1 & 0 \\
\hline 22 & $\begin{array}{l}\ldots \text { fornecem oportunidades } \\
\text { para que você tome decisões } \\
\text { sobre o tratamento? }\end{array}$ & 7 & 6 & 5 & 4 & 3 & 2 & 1 & 0 \\
\hline 23 & $\begin{array}{l}\ldots \quad \text { respondem a suas } \\
\text { perguntas de modo que você } \\
\text { compreenda tudo? }\end{array}$ & 7 & 6 & 5 & 4 & 3 & 2 & 1 & 0 \\
\hline 24 & $\begin{array}{l}\text {.. explicam o que estão } \\
\text { fazendo quando você está } \\
\text { acompanhando seu (sua) } \\
\text { filho(a) na terapia? }\end{array}$ & 7 & 6 & 5 & 4 & 3 & 2 & 1 & 0 \\
\hline 25 & $\begin{array}{l}\text {... reconhecem que a família } \\
\text { tem a palavra final quando } \\
\text { fazem decisões sobre o } \\
\text { tratamento do(a) filho(a)? }\end{array}$ & 7 & 6 & 5 & 4 & 3 & 2 & 1 & 0 \\
\hline 26 & $\begin{array}{lcc}\ldots & \text { comunicam sobre } & \text { os } \\
\text { resultados de avaliações? }\end{array}$ & 7 & 6 & 5 & 4 & 3 & 2 & 1 & 0 \\
\hline 27 & $\begin{array}{l}\text {... fornecem informações por } \\
\text { escrito sobre o desempenho } \\
\text { de seu (sua) filho(a) na } \\
\text { terapia? }\end{array}$ & 7 & 6 & 5 & 4 & 3 & 2 & 1 & 0 \\
\hline 28 & $\begin{array}{l}\text {... pedem sua opinião quando } \\
\text { discutem sobre recursos } \\
\text { auxiliares ou serviços? }\end{array}$ & 7 & 6 & 5 & 4 & 3 & 2 & 1 & 0 \\
\hline
\end{tabular}




\begin{tabular}{|c|c|c|c|c|c|c|c|c|c|}
\hline 29. & $\begin{array}{l}\text {... proporcionam um ambiente } \\
\text { acolhedor ao invés de dar } \\
\text { somente informações? }\end{array}$ & 7 & 6 & 5 & 4 & 3 & 2 & 1 & 0 \\
\hline 30. & $\begin{array}{l}\text {... informam detalhes sobre } \\
\text { serviços realizados com seu } \\
\text { (sua) filho(a), por exemplo, as } \\
\text { razões para indicá-los, os tipos } \\
\text { de terapias e duração? }\end{array}$ & 7 & 6 & 5 & 4 & 3 & 2 & 1 & 0 \\
\hline 31. & $\begin{array}{l}\text {... tratam você como um } \\
\text { indivíduo e não apenas como } \\
\text { pai ou responsável por uma } \\
\text { criança com deficiência? }\end{array}$ & 7 & 6 & 5 & 4 & 3 & 2 & 1 & 0 \\
\hline 32. & $\begin{array}{l}\text {... estabelecem metas a curto } \\
\text { e longo prazo para seu (sua) } \\
\text { filho(a)? }\end{array}$ & 7 & 6 & 5 & 4 & 3 & 2 & 1 & 0 \\
\hline
\end{tabular}

\begin{tabular}{|c|c|c|c|c|c|c|c|c|c|}
\hline Dur & nte o procedimento terapêutico & & & & dique & req & & & \\
\hline $\begin{array}{l}\text { Cor } \\
\text { PR } \\
\text { SE }\end{array}$ & $\begin{array}{l}\text { que frequência os } \\
\text { FISSIONAIS QUE CUIDAM DE } \\
\text { FILHO... }\end{array}$ & Sempre & & & $\begin{array}{c}\text { Às } \\
\text { vezes }\end{array}$ & & & Nunca & $\begin{array}{l}\text { Não se } \\
\text { aplica }\end{array}$ \\
\hline 33. & $\begin{array}{l}\text {... se dirigem a você pelo } \\
\text { nome e não simplesmente } \\
\text { como o responsável pelo } \\
\text { paciente (por exemplo, não se } \\
\text { referem a você como "pai" ou } \\
\text { "mãe")? }\end{array}$ & 7 & 6 & 5 & 4 & 3 & 2 & 1 & 0 \\
\hline 34. & $\begin{array}{l}\ldots \text { planejam o tratamento } \\
\text { juntos para que o mesmo } \\
\text { objetivo seja trabalhado? }\end{array}$ & 7 & 6 & 5 & 4 & 3 & 2 & 1 & 0 \\
\hline 35. & $\begin{array}{l}\text {... asseguram de que você tem } \\
\text { oportunidades para que opine } \\
\text { sobre os objetivos do } \\
\text { tratamento? }\end{array}$ & 7 & 6 & 5 & 4 & 3 & 2 & 1 & 0 \\
\hline 36. & $\begin{array}{l}\text {.. fazem você se sentir um } \\
\text { parceiro no tratamento de seu } \\
\text { (sua) filho(a)? }\end{array}$ & 7 & 6 & 5 & 4 & 3 & 2 & 1 & 0 \\
\hline 37. & 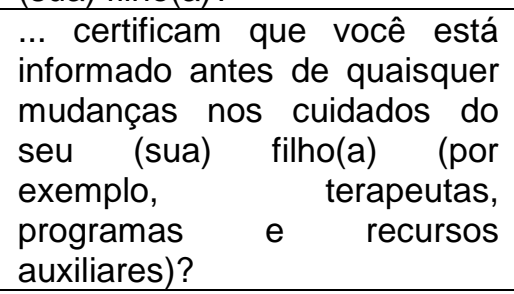 & 7 & 6 & 5 & 4 & 3 & 2 & 1 & 0 \\
\hline 38. & $\begin{array}{l}\text {.. auxiliam você a se sentir } \\
\text { competente } \\
\text { responsável pela criança? }\end{array}$ & 7 & 6 & 5 & 4 & 3 & 2 & 1 & 0 \\
\hline 39. & $\begin{array}{l}\text {... fornecem informações por } \\
\text { escrito do progresso do(a) seu } \\
\text { (sua) filho(a)? }\end{array}$ & 7 & 6 & 5 & 4 & 3 & 2 & 1 & 0 \\
\hline 40. & $\begin{array}{l}\text {... se preocupam com as } \\
\text { necessidades de seu (sua) } \\
\text { filho(a) conforme ele(a) } \\
\text { cresce? }\end{array}$ & 7 & 6 & 5 & 4 & 3 & 2 & 1 & 0 \\
\hline 41. & $\begin{array}{l}\text {... disponibiliza tempo } \\
\text { suficiente para conversar com } \\
\text { você de modo que não se } \\
\text { sinta apressado? }\end{array}$ & 7 & 6 & 5 & 4 & 3 & 2 & 1 & 0 \\
\hline
\end{tabular}




\begin{tabular}{|c|c|c|c|c|c|c|c|c|c|}
\hline 42. & $\begin{array}{l}\text {... tratam você e sua família } \\
\text { como pessoas e não como } \\
\text { uma "doença" (por exemplo, } \\
\text { não se referem a você como } \\
\text { um diagnóstico, tal como "o de } \\
\text { deficiência auditiva"? }\end{array}$ & 7 & 6 & 5 & 4 & 3 & 2 & 1 & 0 \\
\hline 43. & $\begin{array}{l}\text {... escutam o que você tem a } \\
\text { dizer sobre as necessidades } \\
\text { de seu (sua) filho(a) por } \\
\text { recursos auxiliares, serviços, } \\
\text { etc.? }\end{array}$ & 7 & 6 & 5 & 4 & 3 & 2 & 1 & 0 \\
\hline 44. & $\begin{array}{l}\text {... estão disponíveis para você } \\
\text { como um suporte (por } \\
\text { exemplo, apoio emocional, } \\
\text { proteção, informação)? }\end{array}$ & 7 & 6 & 5 & 4 & 3 & 2 & 1 & 0 \\
\hline 45. & $\begin{array}{l}\text {... fornecem informações sobre } \\
\text { seu (sua) filho(a) que sejam } \\
\text { consistentes de pessoa a } \\
\text { pessoa? }\end{array}$ & 7 & 6 & 5 & 4 & 3 & 2 & 1 & 0 \\
\hline
\end{tabular}

Centro se refere à equipe envolvida diretamente ou não com seu (sua) filho(a). Além dos profissionais da saúde, podem incluir-se, também, pessoas da equipe de suporte, tais como administrativa, de coordenação, de limpeza, etc.

\begin{tabular}{|c|c|c|c|c|c|c|c|c|c|}
\hline NO l & TIMO ANO, & & & & Indiqu & frequên & & & \\
\hline $\begin{array}{l}\mathrm{CO} \\
\mathrm{CEI} \\
\mathrm{RE}\end{array}$ & $\begin{array}{l}\text { QUE FREQUÊNCIA O } \\
\text { TRO DO QUAL VOCÊ } \\
\text { EBEU OS SERVIÇOS... }\end{array}$ & Sempre & $\begin{array}{l}\text { Quase } \\
\text { sempre }\end{array}$ & $\begin{array}{l}\text { Muitas } \\
\text { vezes }\end{array}$ & $\begin{array}{c}\text { Às } \\
\text { vezes }\end{array}$ & $\begin{array}{l}\text { Poucas } \\
\text { vezes }\end{array}$ & $\begin{array}{c}\text { Rarament } \\
\mathrm{e}\end{array}$ & Nunca & $\begin{array}{l}\text { Não se } \\
\text { aplica }\end{array}$ \\
\hline 46. & $\begin{array}{l}\ldots \\
\text { informações a você em } \\
\text { vários formatos, tais como } \\
\text { folheto, kit, vídeo, etc.? }\end{array}$ & 7 & 6 & 5 & 4 & 3 & 2 & 1 & 0 \\
\hline 47. & $\begin{array}{l}\text {... possui uma equipe de } \\
\text { suporte educada e } \\
\text { prestativa com você e sua } \\
\text { família? }\end{array}$ & 7 & 6 & 5 & 4 & 3 & 2 & 1 & 0 \\
\hline 48. & $\begin{array}{l}\text {... fornece informações } \\
\text { sobre os tipos de serviços } \\
\text { oferecidos no Centro ou } \\
\text { em sua comunidade? }\end{array}$ & 7 & 6 & 5 & 4 & 3 & 2 & 1 & 0 \\
\hline 49. & $\begin{array}{lr}\text {... promove reuniões de } \\
\text { pais e/ou responsáveis } \\
\text { para } & \text { compartilhar } \\
\text { experiências r social, } \\
\text { informativa e profissional? }\end{array}$ & 7 & 6 & 5 & 4 & 3 & 2 & 1 & 0 \\
\hline 50. & $\begin{array}{l}\text {... promove oportunidades } \\
\text { para encontros com } \\
\text { especialistas e pais sobre } \\
\text { assuntos do interesse? }\end{array}$ & 7 & 6 & 5 & 4 & 3 & 2 & 1 & 0 \\
\hline 51. & $\begin{array}{l}\text {.. fornece suporte para } \\
\text { enfrentar os impactos da } \\
\text { deficiência na infância }\end{array}$ & 7 & 6 & 5 & 4 & 3 & 2 & 1 & 0 \\
\hline
\end{tabular}




\begin{tabular}{|c|c|c|c|c|c|c|c|c|c|}
\hline & $\begin{array}{l}\text { (como proteção de seus } \\
\text { interesses ou informações } \\
\text { sobre } \\
\text { assistenciais)? }\end{array}$ & & & & & & & & \\
\hline 52. & $\begin{array}{l}\text {... comunica você sobre as } \\
\text { razões de conferências, } \\
\text { reuniões, etc. sobre seu } \\
\text { (sua) filho(a)? }\end{array}$ & 7 & 6 & 5 & 4 & 3 & 2 & 1 & 0 \\
\hline 53. & $\begin{array}{l}\text {... disponibiliza } \\
\text { informações sobre a } \\
\text { deficiência da criança (por } \\
\text { exemplo, causas, avanços, } \\
\text { perspectivas futuras)? }\end{array}$ & 7 & 6 & 5 & 4 & 3 & 2 & 1 & 0 \\
\hline 54. & $\begin{array}{l}\text {... fornece orientações em } \\
\text { como obter informações ou } \\
\text { o contato com outros } \\
\text { responsáveis (por } \\
\text { exemplo, um recurso de } \\
\text { banco de dados para os } \\
\text { pais do Centro)? }\end{array}$ & 7 & 6 & 5 & 4 & 3 & 2 & 1 & 0 \\
\hline 55. & $\begin{array}{l}\text {... garante oportunidades } \\
\text { para que toda a família } \\
\text { obtenha informações? }\end{array}$ & 7 & 6 & 5 & 4 & 3 & 2 & 1 & 0 \\
\hline 56. & $\begin{array}{l}\text {... possui informações } \\
\text { gerais disponíveis sobre } \\
\text { outras preocupações } \\
\text { (custos, aconselhamento } \\
\text { genético, compromissos, } \\
\text { sexualidade)? }\end{array}$ & 7 & 6 & 5 & 4 & 3 & 2 & 1 & 0 \\
\hline
\end{tabular}

Qual seu grau de parentesco com a criança com deficiência?

$\begin{array}{llll}\square & \text { Mãe biológica } & \square & \text { Pai biológico } \\ \square & \text { Madrasta } & \square & \text { Padrasto } \\ \square & \text { Mãe adotiva } & \square & \text { Pai adotivo } \\ \square & \text { Mãe de criação } & \square & \text { Pai de criação }\end{array}$

Outro responsável, especifique, por favor.

Em qual data você completou o questionário?

dia/mês/ano

OUTROS COMENTÁRIOS: 
POR FAVOR, ASSEGURAMOS QUE TODAS AS INFOFMAÇÕES SÃO TOTALMENTE CONFIDENCIAIS QUANDO COMPLETADAS. OBRIGADO. 
190

Anexo B - Procedimentos técnicos da tradução segundo a proposta de caracterização de Barbosa (2004)

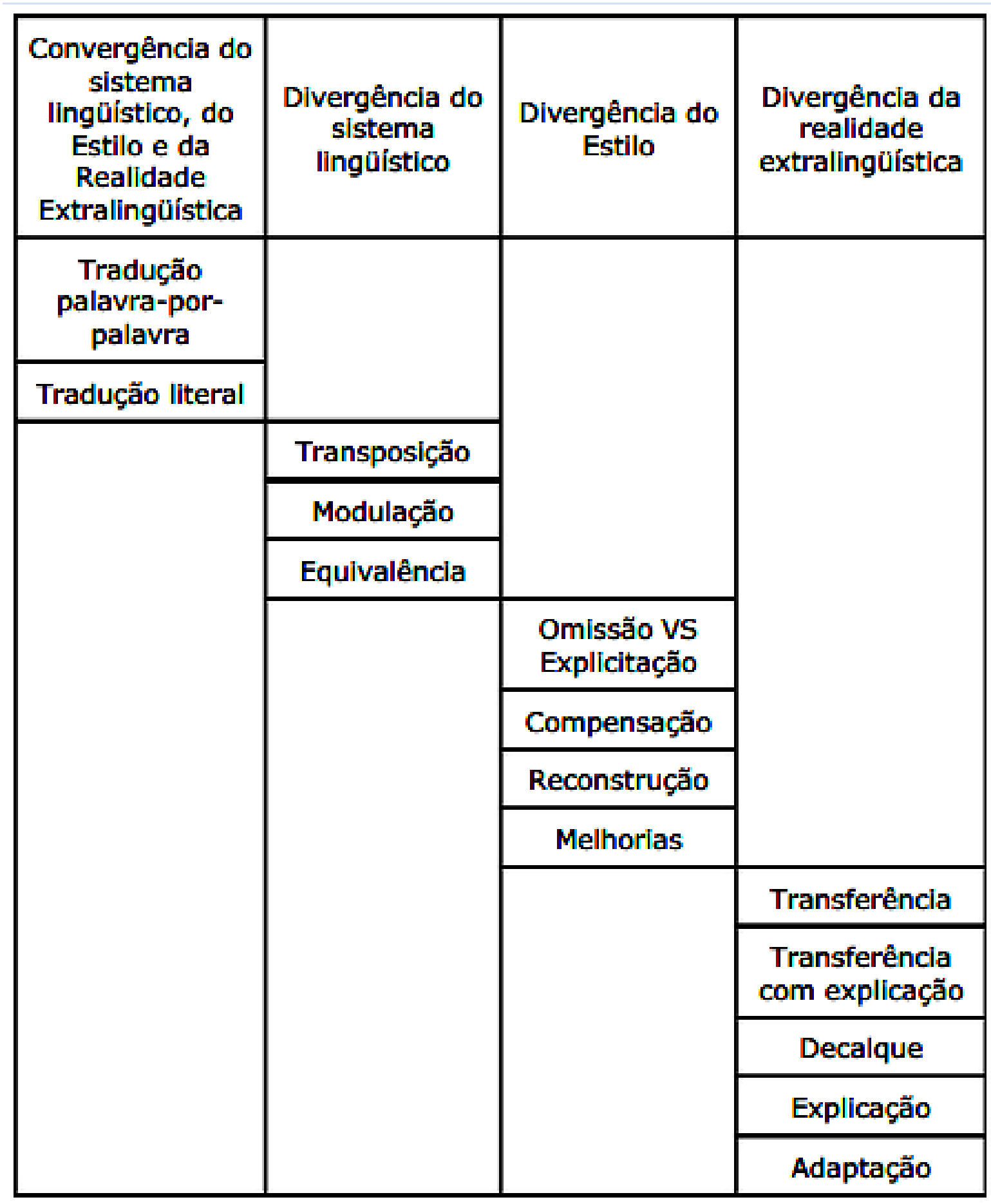

